UNIVERSIDADE DE SÃO PAULO

FACULDADE DE DIREITO

ANNA BEATRIZ ALVES MARGONI

\title{
A DESCONSIDERAÇÃO DA PERSONALIDADE JURÍDICA NOS GRUPOS DE SOCIEDADES
}

SÃo PAULO 


\title{
A DESCONSIDERAÇÃO DA PERSONALIDADE JURÍDICA NOS GRUPOS DE SOCIEDADES
}

\author{
Dissertação apresentada à Faculdade de Direito \\ da Universidade de São Paulo para obtenção do \\ título de Mestre em Direito Comercial.
}

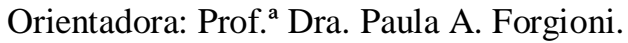

\section{SÃO PAULO}


MARGONI, Anna Beatriz Alves

A Desconsideração da Personalidade Jurídica nos Grupos de Sociedades

Dissertação apresentada à Faculdade de Direito da Universidade de São Paulo para obtenção do título de Mestre em Direito Comercial.

Aprovada em:

Banca Examinadora

Prof. Dr. Instituição:

Julgamento: Assinatura:

Prof. Dr. Instituição:

Julgamento: Assinatura:

Prof. Dr. Instituição:

Julgamento: Assinatura: 
A meus pais. 


\section{AGRADECIMENTOS}

Em primeiro lugar, à minha família, em especial meus pais e meu irmão, pelo apoio incondicional e pelas palavras de incentivo. E, também, pelos palpites sempre bem humorados sobre este trabalho - mesmo aqueles sem qualquer utilidade prática, já que nenhum deles possui formação jurídica.

À minha Orientadora, Professora Paula A. Forgioni, por aceitar orientar-me na elaboração desta dissertação.

Aos professores Viviane Muller Prado e José Alexandre Tavares Guerreiro, pelas inestimáveis contribuições feitas quando do exame de qualificação. Especialmente com relação ao professor Guerreiro, nunca poderei agradecer o suficiente as inúmeras conversas e idéias que se seguiram, após este exame, e sem as quais este trabalho não teria sido feito.

Ao professor Erasmo Valladão de Azevedo e Novaes França, como já dito nos agradecimentos de minha tese de láurea, por despertar em mim a paixão pelo Direito Comercial.

Por fim, a todos os amigos que me incentivaram, cada um a seu modo, a concluir esta pesquisa. Em especial, a Carla Mosna Tomazella, com quem dividi o solitário caminho da elaboração de um trabalho acadêmico, além das agruras, a insegurança e o cansaço dele decorrentes. A conclusão da pesquisa trouxe um bônus: uma grande amiga. 


\section{RESUMO}

A criação de grupos societários é, nos dias de hoje, provavelmente uma das técnicas mais utilizadas para a organização da atividade empresarial. As eficiências deles decorrentes, muitas vezes, não podem ser alcançadas pelo emprego de outras formas societárias. Dentre as possíveis alternativas para a estruturação de grupos societários, os grupos de fato são maioria no cenário econômico brasileiro. Inspirados no modelo societário alemão, estes grupos caracterizam-se pela união de sociedades em relações de controle e coligação, nos quais uma sociedade de comando exerce direção unitária sobre as demais sociedades integrantes do grupo, conferindo-lhes unidade econômica. A legislação societária brasileira, contudo, contém algumas falhas no que diz respeito à regulamentação dos grupos de sociedade. Mesmo no direito comparado, há críticas aos modelos de regulamentação existentes. No caso brasileiro, o principal elemento caracterizador dos grupos societários - a direção unitária - não é previsto na legislação. Além disso, a sistemática da lei é deficiente ao definir mecanismos de proteção aos interesses de acionistas minoritários e credores. Em vista disso, a jurisprudência tem empregado a desconsideração da personalidade jurídica das sociedades integradas em grupos para tutelar estes interesses. Em que pese a válida tentativa da jurisprudência de evitar que a ausência de um regramento adequado, para os grupos societários, prejudique interesses de credores e acionistas minoritários, a utilização da técnica da desconsideração para tanto não observa os princípios determinados para a sua aplicação e gera grande insegurança jurídica. Esta é a análise proposta neste trabalho.

Palavras-chave: Sociedade anônima. Grupos de sociedade. Grupo de fato. Personalidade jurídica. Desconsideração. 


\begin{abstract}
The creation of corporate groups is, nowadays, probably one of the most used techniques for organizing the enterprise. Efficiencies resulting from them very often cannot be reached by using other corporate forms. Among the possible alternatives for structuring groups of companies, de facto groups are the majority in Brazilian economic scenario. Inspired in the German corporate model, these groups are characterized by the union of companies in control and affiliation relations, where a parent company exercises unitary direction over the other companies integrating the group, granting them economic unit. Brazilian corporations' law, however, has some flaws as regards the rules applicable to corporate groups. Even in comparative law, there is criticism to the existing regulating models. In Brazil, the main element that characterizes the group of companies - the unitary direction - is not set forth in law. Besides that, the law's systematic is deficient in defining mechanisms for the protection of the interests of minority shareholders and creditors. In view of that, courts have been using disregard of the legal entity of companies integrated in corporate groups to protect such interests. Despite of the valid attempt of the courts to avoid that the lack of proper rules for groups of companies jeopardize interests of creditors and minority shareholders, the use of the disregard technique for this purpose does not observe the principles for its use and results in great legal insecurity. This is the analysis proposed herein.
\end{abstract}

Keywords: Corporation. Groups of companies. De facto groups. Legal entity. Disregard. 


\section{SUMÁRIO}

INTRODUÇÃ 0 ................................................................................................. 10

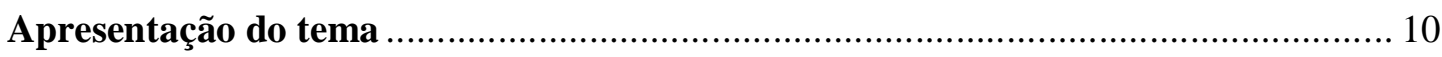

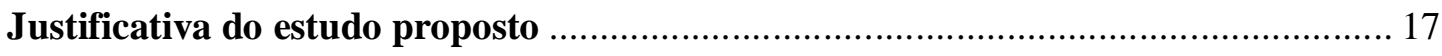

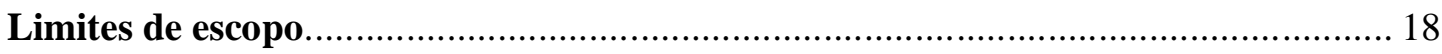

\section{CAPÍTULO 1}

SOCIEDADES ANÔNIMAS: ORIGENS, EVOLUÇÃO E FUNÇÃO

DA SUA PERSONALIZAÇÃO........................................................................... 20

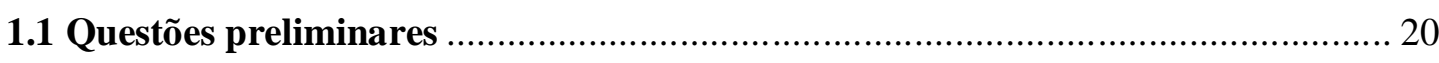

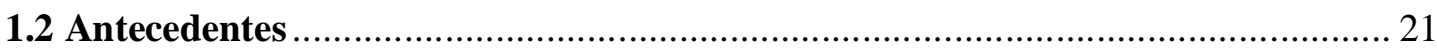

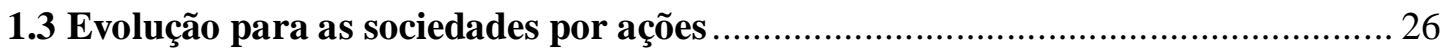

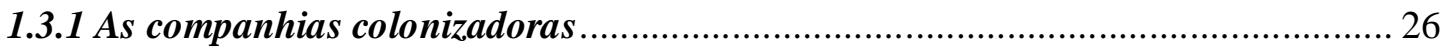

1.3.2 A Revolução Industrial e a liberdade de constituição das sociedades

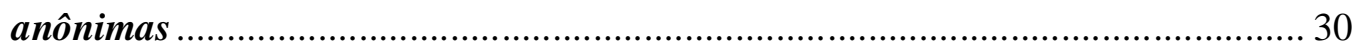

1.4 A personalidade jurídica das sociedades anônimas e sua função ........................ 33

1.4.1 Constituição de novo sujeito de direito ........................................................... 34

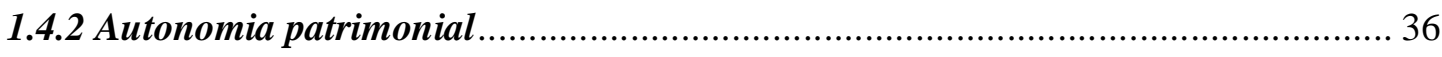

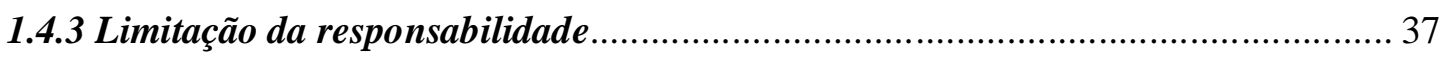

1.4.4 Conclusão: a função da personalização nas sociedades anônimas....................... 38

CAPÍTULO 2

GRUPOS DE SOCIEDADES .................................................................................. 42

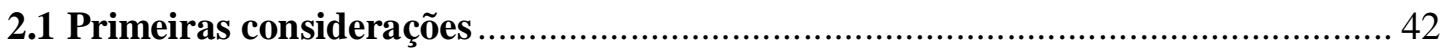

2.1.1 Desenvolvimento do capitalismo e concentração empresarial ............................. 42

2.1.2 Inversão do movimento concentracionista: os grupos societários ......................... 47

2.1.2.1 Razões para a formação de grupos de sociedades............................................. 50

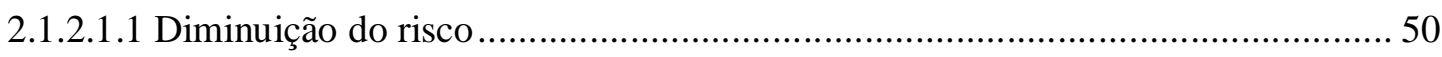

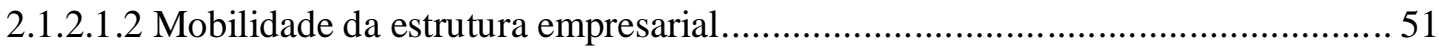

2.1.2.1.3. Flexibilidade da organização empresarial ......................................................... 51

2.1.2.1.4 Redução dos custos de transação ....................................................................... 52

2.1.2.1.5 Redução do investimento inicial de capital .................................................... 54

2.2 Conceito e características dos grupos de sociedades ...................................... 55 
2.2.1 Classificação dos grupos de sociedades 56

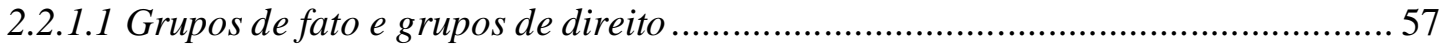

2.2.1.2 Grupos de subordinação e grupos de coordenação .............................................. 58

2.2.1.3 Grupos de base societária, contratual e pessoal.................................................... 60

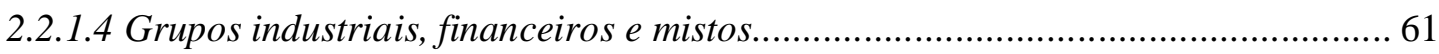

2.2.2 A principal característica dos grupos de sociedades: a direção unitária ................ 62

2.2.2.1 A situação de dependência e o conceito de influência dominante ......................... 65

2.2.2.2 Instrumentos (ou mecanismos) geradores da influência dominante ....................... 70

2.2.2.3 Influência dominante resultante de dependência econômica ................................ 76

2.2.2.4 Conseqüências jurídicas do exercício da influência dominante ........................... 79

2.2.2.5 Influência dominante e direção unitária: conceitos distintos ou pressuposto

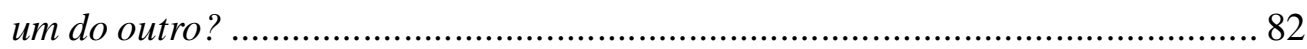

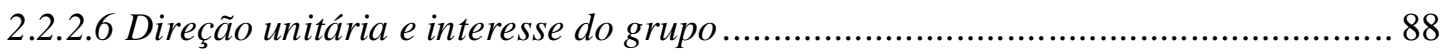

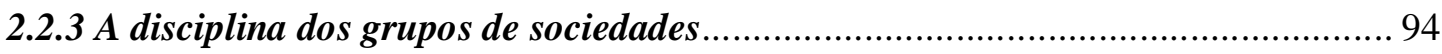

2.2.3.1 Sistemas de regulação dos grupos no direito comparado .................................... 94

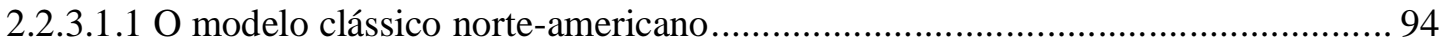

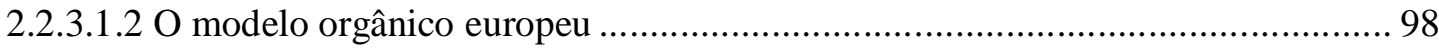

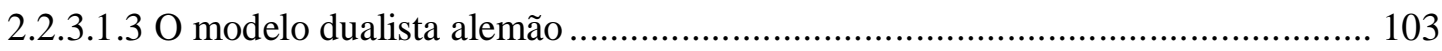

2.2.3.2 Sistema de regulação dos grupos no direito brasileiro ....................................... 108

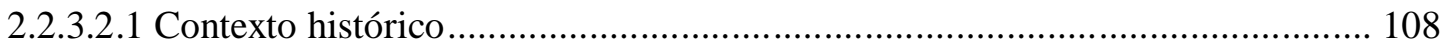

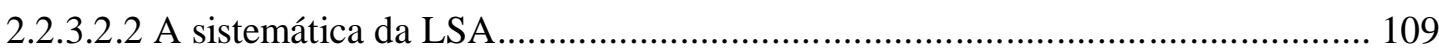

CAPÍTULO 3

DESCONSIDERAÇÃO DA PERSONALIDADE JURÍDICA ................... 119

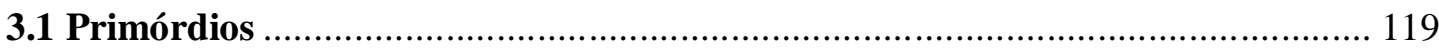

3.1.1 A origem jurisprudencial da desconsideração da personalidade jurídica ............ 119

3.1.2 Brevíssima notícia sobre estudos para sistematização da teoria no direito

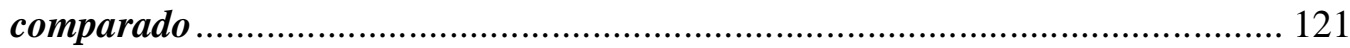

3.2 A desconsideração da personalidade jurídica na doutrina brasileira ................ 125

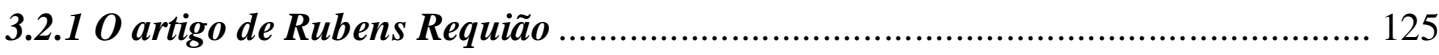

3.2.2 Fábio Konder Comparato e o poder de controle ............................................... 126

3.2.3 A dupla crise da pessoa jurídica de J. Lamartine Corrêa de Oliveira ................... 128

3.3 Nota sobre a experiência dos tribunais brasileiros.......................................... 129

3.4 Previsão legal de casos de desconsideração no ordenamento brasileiro............... 130 
3.4.1 O art. $2^{\circ}, \S 2^{\circ} d a C L T$.

3.4.2 $\mathrm{O}$ art. 28 do $C D C$

3.4.3 O art. $4^{\circ}$ da Lei $n^{\circ}$ 9.605/98

3.4.4 O art. 135 da Lei $n^{\circ} 5.172 / 66$

3.4.5 O art. 18 da Lei $n^{\circ} 8.884 / 94$

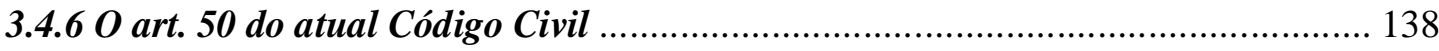

3.5 A desconsideração da personalidade jurídica no direito societário..................... 142

\section{CAPÍTULO 4}

\section{A DESCONSIDERAÇÃO DA PERSONALIDADE JURÍDICA NOS} GRUPOS DE SOCIEDADES

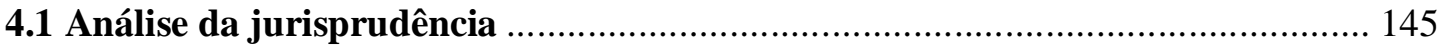

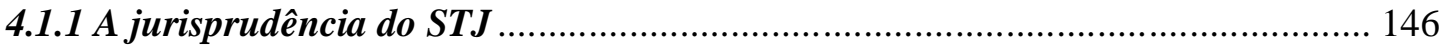

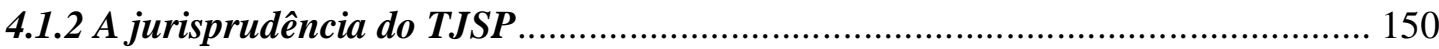

4.2 Análise da aplicação jurisprudencial, em uma perspectiva societária, da desconsideração da personalidade jurídica nos grupos de sociedades .............. 158

4.2.1 O problema da proteção dos credores ................................................................. 159

4.2.2 O problema da proteção dos minoritários .......................................................... 161

4.2.3 A distinção entre a relação de grupo e a relação de mero controle ....................... 164

4.3 Desconsideração como mecanismo de ajuste da realidade.................................. 167

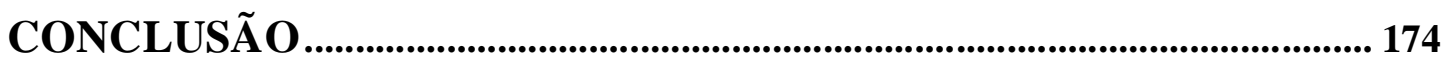

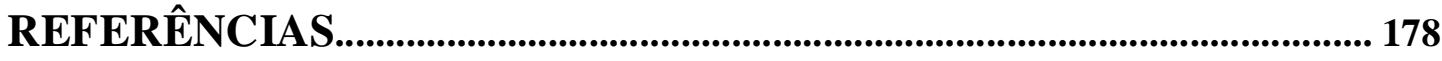

Doutrina

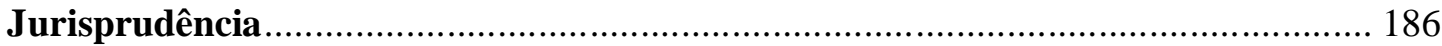

Acórdãos em que a desconsideração da personalidade jurídica nos grupos

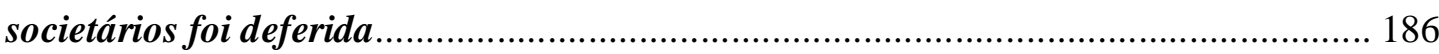

Acórdãos em que a desconsideração da personalidade jurídica nos grupos societários foi indeferida 


\section{INTRODUÇÃO}

\section{Apresentação do tema}

O desenvolvimento dos grupos de sociedades está intimamente relacionado com o desenvolvimento das sociedades, do capitalismo moderno e da economia de mercado.

Na Idade Média, a atividade mercantil era centrada na figura do comerciante individual. Os comerciantes organizavam todos os fatores da produção e respondiam com a totalidade de seu patrimônio pelos resultados da atividade mercantil por eles desenvolvida.

Nesta época surgem, também, as corporações de ofício, encarregadas da proteção dos comerciantes e da disciplina de sua atividade. Esta organização dos agentes do comércio deu margem ao surgimento de novas formas de sociedades que contribuíram para o desenvolvimento do sistema capitalista da época. Os comerciantes passaram a se associar para a consecução de um fim econômico comum e, com isso, novas formas societárias como a sociedade em nome coletivo, a sociedade em comandita simples e a sociedade em conta de participação tornaram-se cada vez mais comuns.

Estas novas formas societárias tinham, contudo, um caráter intuito personae, ou seja, ainda que fosse criada uma sociedade para a exploração da atividade mercantil, a figura do comerciante era fundamental. As unidades de produção, ainda que organizadas sob uma das formas societárias descritas acima, eram de pequenas dimensões. ${ }^{1} \mathrm{O}$ capital exigido para o desenvolvimento da atividade mercantil não era, em regra, elevado e o comerciante assumia integralmente os riscos da sua atividade. Ainda que as atividades fossem desenvolvidas com o auxílio de familiares ou por meio de uma das formas societárias descritas acima, a morte do comerciante geralmente resultava na extinção da empresa $^{2}$ (embora a sociedade em conta de participação e a sociedade em comandita

LAMY FILHO, Alfredo; PEDREIRA, José Luiz Bulhões. A Lei das S.A. - pressupostos, elaboração e aplicação. 3. ed. Rio de Janeiro: Renovar, 1997. v. I. p. 25-32.

2 MUNHOZ, Eduardo Secchi. Empresa Contemporânea e Direito Societário. São Paulo: Juarez de Oliveira, 2002, p. 52. 
simples permitissem, de certa forma, a continuidade da empresa com os herdeiros do comerciante falecido ${ }^{3}$ ).

Esta situação mudou com a era dos descobrimentos. A exploração do Novo Mundo requeria vultosas somas de capital que nenhum comerciante poderia prover sozinho. Além disso, existiam os riscos inerentes a esta empreitada que não poderiam ser assumidos de maneira ilimitada por um único ou por parcos indivíduos.

A exploração do Novo Mundo reclamava a criação de organizações com escala muito superior às existentes até então. ${ }^{4}$ Em decorrência, algumas nações criaram um monopólio estatal para a exploração do comércio no Novo Mundo (como foi o caso de Portugal e Espanha). A Holanda, diversamente, criou uma companhia colonizadora, a Companhia Holandesa das Índias Orientais, que: "tratava-se de o próprio Estado promover a associação de seus súditos, que detivessem capitais, na grande aventura da conquista das riquezas de um mundo novo". 5

Posteriormente, outros países seguiram o exemplo da Holanda e criaram companhias de natureza semelhante, com o objetivo de realizar empreendimentos coletivos de interesse do Estado que as criara. Essas companhias possuíam um acentuado caráter público, pois se tratavam de instrumentos de conquista territorial e de comércio dos Estados absolutistas. Além disso, sua constituição dependia de autorização do Estado, que definia seus direitos, obrigações, privilégios e monopólios. ${ }^{6}$

Não obstante terem estas companhias um caráter eminentemente público, algumas das características principais do atual modelo de sociedades anônimas já estavam ali presentes, como a separação patrimonial, a limitação da responsabilidade dos sócios e a livre circulação das ações. Como ensina Ascarelli:

\footnotetext{
Ibid., p. 53-54.

4 Na lição de LAMY FILHO e PEDREIRA (1997, p. 32): “Os problemas emergentes das transformações que se operavam requeriam, inexoravelmente, crescente volume de capital. As viagens tornaram-se mais longas, e mais demoradas, elevando os gastos e os perigos das expedições marítimas; do mesmo passo, alargava-se, e muito, o tempo de maturação do capital aplicado, o ciclo de investimento, desde o início da viagem até a venda das mercadorias e liquidação dos negócios. Mais ainda, a extensão da viagem a regiões fora da órbita da cultura ocidental tornava imprescindíveis recursos para o estabelecimento de entrepostos, a construção de fortificações, e a manutenção de forças militares para a defesa das conquistas realizadas. E até o comércio começava a fazer-se em rumos novos, com países estranhos à civilização européia, o que tudo induzia à criação de colônias, a que foram levados os países europeus, uns após outros."

5 LAMY FILHO; PEDREIRA, op. cit., p. 32-33.

6 Cf. MUNHOZ, op. cit., p. 55-56.
} 
Nas companhias coloniais já se delineiam os característicos fundamentais, hoje peculiares da sociedade anônima e que a distinguem entre as várias espécies de sociedade: responsabilidade limitada dos sócios e divisão do capital em ações, isto é, possibilidade de serem, as participações de vários sócios, corporificadas em títulos facilmente circuláveis; a pessoa do sócio é, destarte, indiferente à caracterização jurídica da sociedade. ${ }^{7}$

O modelo passou por grande evolução até atingir as feições atuais, mas é fato que, a partir do momento em que passou a ser empregada para o desenvolvimento de atividades mercantis (e independentes de qualquer privilégio concedido pelo Estado), a sociedade anônima tornou-se instrumento de enorme relevância como técnica de organização da empresa na iniciativa privada. ${ }^{8-9-10}$ Ainda com Ascarelli:

Com a liberdade de sua constituição, é natural que as sociedades anônimas se multiplicassem, constituindo o instrumento típico da grande empresa com ações distribuídas entre o público, qual se foi espalhando em consequiência da 'revolução industrial', e sendo também freqüentes como instrumento da média empresa e, às vezes, se bem que a princípio timidamente, da transformação de um negócio individual em negócio familiar ou social. De instrumento jurídico 'excepcional', a sociedade anônima passou a constituir uma forma jurídica 'normal' da empresa econômica e a sua adoção se espalhou pari passu com a industrialização de vários países. ${ }^{11}$

A seguir, uma vez estabelecida e pacificada a figura da sociedade anônima em nossa realidade mercantil, passou-se para uma fase de concentração empresarial.

7 ASCARELLI, Tullio. Problemas das Sociedades Anônimas e Direito Comparado. Campinas: Bookseller, 2001, p. 452.

8 “...] a sociedade anônima aparece como o instrumento jurídico que fornece a estrutura necessária para atender às necessidades da economia industrial, como a mobilização de elevadas somas de capital, a limitação do risco do investidor, a estabilidade de organização e de planejamento (a morte ou as vicissitudes dos acionistas não atingem a sociedade) [...].” (MUNHOZ, 2002, p. 60).

9 Não obstante, Fábio Konder Comparato sustenta que as sociedades de economia mista contemporâneas, criadas sob o patrocínio do Estado para a realização de tarefas que transcendem a simples repartição de lucros entre os sócios, representam um retorno às velhas companhias de comércio privilegiadas. (COMPARATO, Fábio Konder. Aspectos Jurídicos da Macro-Empresa. São Paulo: RT, 1970, p. 59).

10 Ainda sobre este assunto, pitoresca a observação de Fábio Konder Comparato, ao mencionar que Adam Smith sustentava que os homens só trabalham a contento no seu próprio interesse, e não no interesse alheio, e que pelo fato de perseguir interesses distintos dos interesses de seus associados, a sociedade anônima teria um futuro pouco promissor no mundo dos negócios. (Ibid., p. 59-60).

11 ASCARELLI, op. cit., p. 459. 
O regramento jurídico das companhias, possibilitando a limitação do risco dos seus respectivos acionistas ao montante do capital por eles investido, viabilizou o estabelecimento de sociedades dedicadas à produção de grande escala após a Revolução Industrial. Nesta época, verificou-se o crescimento de grandes sociedades comerciais que empregavam altas somas de capital no pagamento da massa assalariada e no investimento em novas técnicas produtivas, tais como o vapor e a eletricidade. As estruturas empresariais passaram por grande crescimento interno e o século XIX foi marcado por grande movimento de fusões e incorporações de empresas. ${ }^{12-13-14}$

Pelos motivos descritos acima, Antunes sustenta que a sociedade anônima teria uma tendência natural para a expansão e crescimento e que, por isso, transformou o universo econômico contemporâneo de um quadro atomístico e concorrencial para um quadro de concentração econômica, o "fenômeno-chave da ordem econômica de nossos dias". 15

Antunes chega a afirmar que a sociedade comercial estaria "predestinada" a fornecer a estrutura legal necessária ao funcionamento do sistema econômico então emergente em virtude de sua aptidão para institucionalizar juridicamente os imperativos financeiros, organizativos e jurídicos inerentes à dinâmica concentracionista deste sistema. $^{16}$

A alta concentração de empresas verificada no século XIX gerou, contudo, diversos problemas de organização e gestão das mesmas. A solução encontrada para os problemas

12 PRADO, Viviane Muller. Conflito de Interesses nos Grupos Societários. São Paulo: Quartier Latin, 2006, p. 18.

13 No mesmo sentido, Fábio Konder Comparato: “Atuando, a um tempo, como causa e consequiência desse crescimento econômico aparentemente incoercitível, deparamos um vasto processo de acumulação do capital e de concentração empresarial. [...] O fabricante da época necessitava de abundante capital circulante para o suprimento em matérias primas e o pagamento de salários, mas de pouco capital fixo, dado o incipiente maquinismo. $\mathrm{O}$ crédito bancário ou comercial supria essa necessidade de recursos de giro, e as empresas operavam com uma exigibilidade até sete ou oito vezes superior ao volume de seus investimentos permanentes. Um século depois, a situação se inverte. O maquinismo domina a indústria em toda parte. Os grandes projetos de canais, portos e ferrovias exigiam enormes investimentos de risco, que só a sociedade por ações poderia recolher.” (COMPARATO, Fábio Konder. Os Grupos Societários na Nova Lei de Sociedades por Ações. RDM, n. 23, p. 91-107, 1976, p. 91).

14 Vale lembrar, conforme destacado por Antunes, que a transformação das estruturas econômicas do contexto em que se insere a expansão das sociedades anônimas ocasionou transformações também na estrutura jurídica destas organizações. Ao mesmo tempo em que a empresa explorada por uma pessoa física passou, gradualmente, a ser explorada por uma sociedade comercial, o tradicional direito dos comerciantes aos poucos passou a dar lugar a um direito das sociedades comerciais. $\mathrm{O}$ autor salienta, contudo, que embora as transformações econômicas a que hora nos referimos sejam datadas do final do século XVIII, a reação do sistema jurídico ocorreu com quase um século de atraso. (ANTUNES, José A. Engrácia. Os Grupos de Sociedades. 2. ed. Coimbra: Almedina, 2002, p. 37-38).

15 Ibid., p. 47.

16 ANTUNES, 2002, p. 37. 
decorrentes da expansão interna da empresa foi a sua expansão externa: a grande sociedade isolada passa a ser substituída por uma estrutura formada por diversas sociedades menores, cada uma com autonomia jurídica, patrimonial e organizacional, mas subordinadas a uma direção unitária exercida, na maioria das vezes, por uma "sociedade-mãe". ${ }^{17}$ Como na famosa passagem de Comparato: "As grandes massas empresariais explodiram em múltiplos satélites, gravitando em torno do núcleo inicial. Doravante, a macrocompanhia passava a ser substituída pelo grupo de empresas, assegurando, como no mistério da Santíssima Trindade, a unidade na diversidade." ${ }^{18}$

Fala-se da figura dos grupos de sociedades. Neles, a atividade econômica é desenvolvida por várias sociedades, sob a direção unitária de um ou mais acionistas comuns, direta ou indiretamente. A principal conseqüência desta direção unitária exercida nos grupos para o desenvolvimento de atividade econômica comum é sintetizada por Forgioni: “[...] em muitas situações, além do interesse de cada empresa envolvida, há de se considerar aquele do grupo como um todo. Trata-se do chamado 'institucionalismo grupal', que substituiu o chamado institucionalismo societário por aquele 'de grupo' $[\ldots] . " 19$

No direito brasileiro, os grupos societários podem ser de coordenação ou de subordinação, estes últimos podendo ser de fato ou de direito.

Os grupos de coordenação são tipificados no Capítulo XXII da Lei nº 6.404/76 (Lei das Sociedades Anônimas - LSA, conforme alterada posteriormente), que regulamenta os consórcios. Grupos societários de coordenação são aqueles nos quais duas ou mais empresas convencionam empregar esforços comuns para o desenvolvimento de uma atividade, mas cada uma mantendo integralmente a sua independência da outra.

No que diz respeito aos grupos de subordinação, a LSA estabelece um sistema dual. De um lado há os grupos de fato, criados mediante relações de controle e coligação entre empresas, e de outro lado os grupos de direito, que são criados mediante convenção formal assinada entre a empresa dominante e as empresas dominadas.

PRADO, 2006, p. 18.

18 COMPARATO, 1976, p. 92.

19 FORGIONI, Paula A. A Evolução do Direito Comercial Brasileiro: da mercancia ao mercado. São Paulo: RT, 2009, p. 161. 
Com relação aos grupos de direito, como ensinam Teixeira e Guerreiro, na sistemática da LSA, as sociedades vinculadas convencionam combinar recursos ou esforços para a realização dos respectivos objetos, ou a participar de empreendimentos comuns. A subordinação evidencia-se com a existência de uma sociedade dita de comando, que exerce o controle das sociedades filiadas, nos termos da convenção grupal firmada entre as referidas sociedades. ${ }^{20}$

Desta forma, o objeto social das sociedades filiadas subordina-se aos interesses comuns do grupo, dominado pela sociedade de comando, mas sempre em observância aos termos da convenção celebrada. Os documentos que constituem o grupo são públicos e arquivados no Registro do Comércio.

Do texto legal depreendem-se os seguintes pressupostos do grupo de sociedades no direito brasileiro: “(a) o grupo tem escopo peculiar e distinto do objeto de cada sociedade participante ou filiada; (b) o grupo pressupõe uma sociedade de comando, necessariamente brasileira, a qual deve exercer, direta ou indiretamente, e de modo permanente, o controle das sociedades participantes ou filiadas como titular de direitos de sócios ou acionistas, ou mediante acordo com outros sócios ou acionistas $\left(\operatorname{art} .265, \S 1^{\circ}\right) ., 21$

Na legislação pátria, dizem ainda os autores acima referidos, não há grupo de direito se não existirem vínculos societários entre a sociedade de comando e as demais sociedades integrantes do grupo. Esses vínculos societários implicam em controle das sociedades filiadas, ainda que indireto, na acepção do art. 116, caput e do art. 243, §2 $2^{\circ}$ da LSA. Entretanto, cumpre destacar que mesmo os grupos de direito devem respeitar as restrições à participação recíproca determinadas no art. 244 da LSA.

Outra característica dos grupos de direito é o fato de que tais estruturas societárias podem ser integradas por sociedades de quaisquer tipos jurídicos (diferentemente do regramento de grupos alemão, por exemplo, nos quais o grupo pode ser integrado por entidades não-societárias). A única exigência da lei é a de que a sociedade de comando do grupo tenha controle de nacionalidade brasileira. ${ }^{22}$

20 TEIXEIRA, Egberto Lacerda; GUERREIRO, José Alexandre Tavares. Das Sociedades Anônimas no Direito Brasileiro. São Paulo: Bushatsky, 1979. v. II.

21 Ibid., p. 772

22 TEIXEIRA; GUERREIRO, 1979, p. 772-773. 
No que tange à administração, é a convenção de grupo que vai determinar se a sociedade de comando poderá orientar as atividades das filiadas a um fim estranho aos seus respectivos objetos sociais. Os administradores das sociedades filiadas, então, adquirem novas dimensões de suas funções, pois passam a atuar não mais em conformidade com os objetivos da sociedade que administram, mas sim de acordo com os objetivos do grupo. "A autonomia de gestão da filiada cede passo, nesse ponto, à coordenação ou subordinação dos administradores, tal como resultar estabelecido na convenção". ${ }^{23}$

Com relação aos grupos de fato, a principal característica é a de que as sociedades unem-se por relações de controle e coligação nos termos dos $\S \S 1^{\circ}, 2^{\circ}, 4^{\circ}$ e $5^{\circ}$ do art. 243 da LSA, não tendo, a sociedade de controle, a prerrogativa de fazer com que as sociedades controladas se desviem de seu objeto particular ${ }^{24}$.

Sendo assim, as sociedades controladas preservam sua independência patrimonial e jurídica, atuando como sociedades independentes da sociedade controladora. Nos grupos de fato, via de regra, não há que se falar em interesse do grupo ou "institucionalismo grupal", para utilizar a expressão de Forgioni indicada anteriormente. Essa suposta ${ }^{25}$ independência das sociedades controladas integradas em um grupo de fato é corroborada pelas disposições contidas nos arts. 245 e 246 da LSA, que tratam dos prejuízos causados pelos administradores e sociedade controladora às sociedades controladas.

Os administradores não podem favorecer a sociedade controlada, controladora ou coligada em prejuízo da companhia, cabendo a tais administradores zelar para que as operações entre as sociedades integradas em um grupo de fato observem condições estritamente comutativas. Alternativamente, caso tais operações não sejam feitas em bases comutativas, deve haver pagamento compensatório adequado à sociedade prejudicada. Por fim, os administradores respondem pelas perdas e danos que causarem à companhia pela prática de atos realizados em desacordo com o previsto acima.

Com relação à sociedade controladora, a regra é bastante semelhante. Os danos causados à companhia em decorrência da infração às obrigações decorrentes do exercício do poder de controle na sociedade devem ser reparados.

Ibid., p. 774.

Ibid., p. 771.

25 No decorrer desta dissertação ficará claro porque esta independência é apenas suposta. 
Sendo assim, poder-se-ia adotar como síntese da distinção entre grupos de fato e grupos de direito a observação de Prado: “A convenção grupal legaliza a relação de dependência econômica [...]", ao passo que o grupo de fato "seria uma exceção e serviria às estruturas descentralizadas, com grande autonomia das controladas". ${ }^{26}$

\section{Justificativa do estudo proposto}

Não obstante o regramento dos grupos de sociedade na LSA ser bastante inovador para a época em que a LSA foi promulgada e o fato de a legislação fazer uma distinção nítida entre grupos de fato e grupos de direito, o regramento pátrio não reflete adequadamente a realidade econômica. Os grupos de direito, nas palavras de Comparato e Salomão Filho, são "letra morta na realidade empresarial brasileira". ${ }^{27}$

Os motivos que levam a não adoção dos grupos de direito no Brasil são diversos e serão abordados ao longo desta dissertação. Entretanto, pode-se citar a facultatividade da celebração da convenção grupal e, principalmente, o custo decorrente da formação de um grupo de direito, na medida em que esta deliberação enseja direito de recesso aos minoritários nos termos dos arts. 137 e 270 da LSA. De fato, atualmente o número de grupos de direito com convenções grupais registradas na Junta Comercial do Estado de São Paulo é insignificante. ${ }^{28}$

Com relação aos grupos de fato, o problema é outro. A suposta independência e/ou autonomia das sociedades controladas não existe na prática. As sociedades controladas, na maioria dos casos, estão sob a direção unitária da sociedade controladora e têm seus interesses sobrepostos pelos interesses do grupo formado por elas (observado que, muitas vezes, esse tal interesse do grupo se confunde com os interesses da própria controladora).

26 PRADO, Viviane Muller. Grupos Societários: Análise do Modelo da Lei 6.404/76. Revista Direito GV, v. 1, n. 2, p. 5-28, jun./dez. 2005, p. 13.

27 COMPARATO, Fabio Konder; SALOMÃO FILHO, Calixto. O poder de Controle na Sociedade Anônima. 5. ed. Rio de Janeiro: Forense, 2008, p. 414.

28 Apenas para ilustrar esta informação: O website da Junta Comercial do Estado de São Paulo (www.jucesp.fazenda.sp.gov.br) possibilita, a qualquer interessado, a realização de busca de empresas nela registradas segundo diversos critérios. Um dos critérios que pode ser escolhido é o tipo da empresa, dentre os quais existe a opção "grupos". Em pesquisa realizada em 15 de julho de 2010, a busca retornou com apenas dez registros de grupos formalmente constituídos no Estado de São Paulo. 
Assim, instala-se a dependência entre as sociedades controladas no grupo de fato, mas sem a existência da convenção grupal que autorizaria esta prática. As regras de responsabilização de administradores e sociedade controladora por prejuízos causados pela prática de atos entre as empresas grupadas em bases não comutativas e por abuso no exercício do poder de controle são mal definidas e há, ainda, regras de conflito de interesses de difícil aplicação. ${ }^{29}$

Este descompasso entre a realidade econômica e as regras previstas na LSA, e a ausência de regras eficazes de responsabilidade, acarretam falta de proteção efetiva a credores e acionistas minoritários e vem fazendo com que seja aplicada aos grupos de fato, com grande freqüência, a desconsideração da personalidade jurídica. É esta a situação que se pretende analisar nesta dissertação.

\section{Limites de escopo}

Feita a breve apresentação do tema a ser tratado nesta dissertação e a justificativa do estudo, cumpre delimitar o escopo do presente trabalho.

Em primeiro lugar, esclarece-se que esta dissertação não abordará questões relacionadas aos grupos de coordenação. Como nestas formas de organização da atividade empresarial não há subordinação do interesse de uma sociedade à outra, mas mera conjunção de esforços para o desenvolvimento de um empreendimento comum, não há que se falar em desconsideração da personalidade jurídica nestes casos.

Em segundo lugar, este trabalho tampouco se ocupará dos grupos de direito. $\mathrm{Na}$ medida em que a convenção grupal estabelece a forma pela qual as sociedades grupadas combinarão esforços e recursos para a realização do objeto do grupo (art. 265 da LSA), a submissão dos interesses da sociedade controlada aos interesses do grupo está autorizada, desde que realizada nos termos da convenção grupal.

29 COMPARATO; SALOMÃO FILHO, 2008, p. 414. 
Além disso, dada a irrelevância da figura dos grupos de direito em nossa realidade empresarial (como dito anteriormente, com pouquíssimos grupos de direito formalmente constituídos e registrados na Junta Comercial do Estado de São Paulo), um estudo aprofundado dos grupos de direito, neste caso, seria pouco produtivo.

Sendo assim, o escopo deste trabalho será a análise da aplicação da desconsideração da personalidade jurídica aos grupos de fato, tal como previstos no Capítulo XX da LSA. 


\section{CAPÍTULO 1}

\section{SOCIEDADES ANÔNIMAS: ORIGENS, EVOLUÇÃO E FUNÇÃO DA SUA PERSONALIZAÇÃO}

\subsection{Questões preliminares}

Conforme explicitado na Introdução, esta dissertação pretende analisar a aplicação da desconsideração da personalidade jurídica aos grupos de sociedade, notadamente os grupos de fato (grupos de subordinação constituídos mediante relações de controle e coligação, sem que seja firmada convenção de grupo entre as sociedades grupadas).

Como dito anteriormente, nos grupos de fato as sociedades controladas permanecem com sua autonomia jurídica e patrimonial, não podendo a sociedade controladora causar prejuízos às controladas em benefício do interesse do grupo, exceto mediante adequada compensação aos prejuízos causados. Em outras palavras, cada sociedade integrante do grupo de fato é uma sociedade autônoma, com personalidade e patrimônio próprios.

Para tratar da desconsideração da personalidade jurídica das empresas integrantes dos grupos de fato, primeiro faz-se necessário analisar o fenômeno da personalização destas sociedades e a função econômica desta personalização. Não se pretende, aqui, fazer uma análise profunda das teorias da pessoa jurídica, pois isto fugiria ao escopo deste trabalho. ${ }^{1} \mathrm{O}$ objetivo é a realização de um apanhado geral do surgimento e da evolução das sociedades anônimas, evidenciando a relevância da personalização nestas sociedades e as conseqüências disso na atual configuração do seu regramento jurídico. Estas considerações influenciam diretamente o surgimento e regramento dos grupos de sociedades.

\footnotetext{
Para uma excelente síntese sobre as teorias sobre a pessoa jurídica, vide CAMARGO, André Antunes Soares de. A Pessoa Jurídica: Um Fenômeno Social Antigo, Recorrente, Multidisplinar e Global. In: FRANÇA, Erasmo Valladão de Azevedo e Novaes (Coord.). Direito Societário Contemporâneo I. São Paulo: Quatier Latin, 2009, p. 281-298.
} 
Vale destacar, também, que apesar de os grupos de sociedades poderem ser formados por sociedades de qualquer natureza, esta dissertação abordará a questão da desconsideração da personalidade jurídica nos grupos de fato com foco principal nas sociedades por ações, exceto quando a análise de casos concretos exigir conduta diversa. Esta limitação justifica-se pelo fato de o regramento dos grupos estar previsto na LSA, além de serem as sociedades anônimas a forma mais sofisticada de organização das sociedades comerciais prevista no direito brasileiro.

\subsection{Antecedentes}

Para se falar nas origens das sociedades anônimas tal como se conhece hoje, é necessário remeter à Idade Média.

Com a queda do Império Romano e durante a Alta Idade Média ${ }^{2}$, os indivíduos passaram a se organizar em comunidades agrícolas auto-suficientes onde a atividade econômica resumia-se quase que exclusivamente à troca de produtos. ${ }^{3}$ Neste contexto surgiram as fraternae societatis, relações associativas erigidas a partir da célula familiar dedicadas ao cultivo e troca de produtos agrícolas. ${ }^{4}$

Nestas formas associativas, os sócios tinham solidariedade ativa e passiva, uma vez que todos os "sócios-irmãos" beneficiavam-se diretamente dos proveitos da atividade comum desempenhada e que, presumidamente, todos os "sócios-irmãos" podiam dispor deste patrimônio comum. ${ }^{5}$

2 Do século VII até as Cruzadas.

3 "[...] per tutto l'alto Medioevo la vita economica si era chiusa all'interno delle proprietà feudali: le risorse della terra e i prodotti del lavoro dovevano bastare al consumo diretto dei produttori e soddisfare le pretese del signore feudal.” (GALGANO, Francesco. Lex Mercatoria, Bolonha: il Mulino, 2001, p. 29).

4 WARDE JÚNIOR, Walfrido Jorge. Responsabilidade dos Sócios. Belo Horizonte: Del Rey, 2007, p. $52-$ 53 .

5 Ibid., p. 54-57. Vide, nas páginas 58 a 62 da mesma obra, as observações do autor indicando a proximidade da fraternae societatis com outra forma de associação bastante antiga prevista no direito alemão, a Gemeinschaften zur gesamten Hand ou Gesamthandsgemeinschaften, a qual o autor traduziu como "comunidades em mão comum". Estas formas associativas não eram personificadas, embora fossem consideradas sujeitos de direito, podendo os sócios ter responsabilidade limitada ou ilimitada. 
Com o passar do tempo e o desenvolvimento das atividades produtivas então desempenhadas, as comunidades agrícolas existentes durante a Alta Idade Média passaram a experimentar:

[...] uma verdadeira revolução agrícola, propiciando, com o emprego de novas técnicas de plantio, o aumento inimaginável da produção e a dispensa da avantajada mão de obra outrora necessária ao cultivo da terra. Os camponeses, a partir do ano mil, seguem para as cidades em busca de sustento. A produção excedente foi em princípio comercializada em feiras locais e depois escoada em mercados mais longínquos. As cidades italianas, de 1050 a 1300, protagonizaram o renascimento do comércio e seu monopólio em águas anteriormente dominadas pelos bizantinos. Elas estabeleceram vigoroso tráfego comercial entre o Oriente e o Ocidente. Todo este processo reativou a economia e acelerou a organização da vida citadina. ${ }^{6}$

Em vista do acima, durante a transição da Alta Idade Média para a Baixa Idade Média $^{7}$, temos também uma transição das relações econômicas da época. Deu-se um substancial desenvolvimento do comércio e, com isso, o Direito Comercial surgiu como um ramo autônomo do Direito ${ }^{8}$.

\section{Como ensina Goldschmidt:}

Il nuovo diritto consuetudinario del commercio si sviluppa, com'è naturale, localmente nelle cita, dove le case delle gilde (logge), le case di compera (casa delle vesti, ecc.), all'estero nello stesso tempo alberghi di commercianti e magazzini di dogana (fondaci), sono centri del commercio all'ingrosso; e con più ampio campo di applicazione nei mercati e nelle fiere per lo più internazionali. Anzi il nuovo diritto delle città, il diritto dei 'cittadini o borghesi' è in massima parte addirittura um diritto dei commercianti non ancora separati corporativamenti dagli artigiani, il nuovo diritto del mercato ̀̀ um ius mercatorum o mercatorium, il quale quase per sola traslazione viene esteso anche

WARDE JÚNIOR, 2007, p. 63.

Das Cruzadas até o século XV.

8 "Na Idade Média, especialmente a partir do século XI, a Europa observou um intenso crescimento comercial, o que se deveu a um período de paz relativa, após o declínio do império romano e as invasões dos bárbaros. Multiplicavam-se as cidades livres e a abertura de novas vias de circulação, o que contribuiu para o desenvolvimento do comércio, que era exercido por profissionais especializados, no âmbito das corporações de ofício. O protagonista central deste sistema econômico era, portanto, o comerciante individual, caracterizando-se o direito comercial por constituir um direito consuetudinário e de classe." (MUNHOZ, 2002, p. 52). 
allá popolazione non commerciale - sebbene non sai vero e próprio diritto commerciale nel senso técnico. ${ }^{9}$

De fato, Forgioni sustenta que o Direito Comercial surgiu das necessidades práticas dos comerciantes ${ }^{10}$ medievais, para os quais os institutos do Direito Romano não eram suficientes para garantir segurança e previsibilidade às relações comerciais, nem para proteger alguns aspectos peculiares da vida mercantil. ${ }^{11-12}$

As corporações de ofício contribuíram substancialmente para este quadro, propiciando o treinamento e o encontro de pessoas dedicadas ao comércio. Além disso, sob a influência destas corporações profissionais, a produção deixou de ser artesanal e passou a adotar técnicas industriais. Nos séculos XIII e XIV foi fundamental a atuação das corporações de ofício na criação de um direito destacado do direito comum aplicado exclusivamente aos comerciantes, disciplinando as relações entre mestres e aprendizes, as jornadas de trabalho, as relações de consumo e os negócios mercantis em geral. ${ }^{13}$

Estas transformações possibilitaram o surgimento de novos tipos de sociedades, utilizadas para o exercício da empresa, e a elas aplicavam-se regras próprias do direito mercantil. Dentre eles podemos destacar a companhia comercial medieval e a sociedade em comandita.

9 GOLDSCHMIDT, Levin. Storia Universale del Diritto Commerciale. Trad. Vittorio Pouchain e Antonio Scialoja. Turim: Unione - Torinese, 1913, p. 104-105.

10 As expressões "comerciante" e "empresário" serão tratadas como sinônimos neste trabalho, embora possa-se inferir uma distinção entre os termos decorrente da evolução do próprio Direito Comercial, inicialmente centrado na figura do comerciante (aquele que praticava atos de comércio), e que posteriormente passou a ocupar-se da figura do empresário (aquele que exerce a empresa). De fato, Paula A. Forgioni considera também como sinônimas as expressões "direito mercantil", "direito comercial" e “direito empresarial” (2009, p. 13). No mesmo sentido, Eduardo Secchi Munhoz sustenta que a expressão "sociedade comercial" foi substituída pela expressão "sociedade empresária" no Código Civil de 2002, em vista da evolução do instituto e da visão atual do direito comercial, centrada na teoria da empresa e não mais no conceito de atos de comércio (2002, p. 52). Em que pese a diferença histórica do conceito, para os fins desta dissertação ambas as expressões terão o mesmo significado: tratam-se de sociedades criadas com o escopo de explorar uma atividade econômica.

11 FORGIONI, Paula A. A Interpretação dos Negócios Empresariais no Novo Código Civil. RDM, ano XLII, n. 130, p. 7-38, abr./jun. 2003, p. 18. No mesmo sentido, ainda com FORGIONI, 2009, p. 36-37.

12 "O direito comercial é uma dimensão da realidade, na qual se imiscuem fatos, regras exógenas e endógenas, o comportamento dos agentes econômicos e outros aspectos ligados a esta mesma realidade; nível de um todo complexo, da estrutura social global. Compõe-se e resulta da sua interação com os demais níveis desse todo, sendo 'sempre, fruto de uma determinada cultura' e de sua história." (FORGIONI, 2009, p. 16).

13 Conforme WARDE JÚNIOR, 2007, p. 64. No mesmo sentido, MUNHOZ, 2002, p. 52. 
As companhias comerciais medievais tinham uma certa inspiração na fraternae societas. Contudo, enquanto na fraternae societas o liame associativo era baseado na copropriedade hereditária indivisa, na companhia comercial medieval o liame associativo passa a ser fundado na livre manifestação da vontade das partes, podendo ser estabelecida entre sócios que não integravam uma mesma família. ${ }^{14}$

Nestas companhias medievais, a responsabilidade dos sócios era ilimitada, em decorrência do mesmo princípio aplicável à fraternae societas (o que Warde Júnior considera ser mais uma evidência de que as companhias medievais tiveram inspiração na fraternae societas): "o forte liame jurídico, que se aperfeiçoava figurativamente entre os membros da companhia pela partilha do pão ${ }^{15}$, determinava a constituição de patrimônio comum, com o qual todos entretinham relação de domínio, que alcançava também os frutos da atividade empresarial." $16-17$

Outra figura relevante desta época é a sociedade em comandita. Originada no instituto da commenda ${ }^{18}$, a sociedade em comandita foi criada em decorrência da necessidade de adaptação das formas societárias então vigentes à prática dos comerciantes. $^{19}$

14 WARDE JÚNIOR, 2007, p. 67-68.

15 Eram relevantes para a identificação dos membros da companhia, dentre outros elementos, o "compartilhamento do pão". Daí a palavra "companhia" vir de cum panis.

16 WARDE JÚNIOR, 2007, p. 68-69.

17 Vale destacar que, para Warde Júnior, a companhia medieval é o tipo societário equivalente às nossas sociedades em nome coletivo. A mesma observação é feita por Galgano: "[...] nacque um nuovo tipo di società, corrispondente all'attuale società in nome collettivo. Negli statuti il suo nome fu 'compagnia'; nel linguaggio dei giuristi dell'epoca si parlò di societas mercatorum: ci si riferì a questa come all'ipotesi di 'plures mercatores expedentes nomen insimul', o quella in cui 'plures mercatores unam mercantiam gerunt vel unam negotionem'. Al rapporto si aplicava il ius mercatorum, anziché il diritto romano, in ragione del fatto che il vincolo sociale univa fra loro più mercanti i quali esercitavano uma medesima empresa." (2001, p. 46).

18 Munhoz explica que o contrato de commenda, de origem italiana, era amplamente utilizado no comércio marítimo do Mediterrâneo. Nele, em regra, a contribuição do capital era apenas do commendator, cabendo ao tractator o exercício da atividade, pela qual apenas este se responsabilizava (2002, p. 53). Alfredo Lamy Filho e José Luiz Bulhões Pedreira sustentam que, pelo contrato de commenda, o commendator entregava ao tractator mercadoria ou dinheiro para a realização de atos de comércio, participando do lucro obtido, sendo que a contribuição de capital podia ser apenas do commendator ou de ambas as partes. $\mathrm{O}$ tractator apresentava-se perante terceiros em nome próprio e não como representante de sociedade ou comunhão, daí a responsabilidade limitada do commendator. Vale destacar, contudo, que Lamy Filho e Pedreira salientam que alguns autores não entendem a commenda como forma societária, pois o capital do commendator não integrava um fim comum. Sendo assim, estes autores sustentam que a sociedade em comandita não seria originária do instituto da commenda, mas sim uma evolução da sociedade em nome coletivo (1997, p. 27).

19 "O aparecimento das sociedades atípicas decorre do descompasso entre as estruturas societárias disponíveis e as necessidades econômicas emergentes." (WARDE JÚNIOR, 2007, p. 72). 
Com o incremento dos riscos inerentes às atividades comerciais, especialmente aquelas que diziam respeito ao transporte marítimo, houve a necessidade de, sob alguma forma, mitigar os riscos do capital empregado na atividade produtiva.

Assim, na sociedade em comandita, os sócios comanditários (capitalistas), contribuíam com capital para o exercício da empresa, ao passo que o sócio comanditado (o que efetivamente desempenhava a atividade mercantil) permanecia como proprietário dos resultados e do patrimônio empregado na empresa. $\mathrm{O}$ sócio comanditado tinha responsabilidade ilimitada no exercício de sua atividade, o comanditário não. Este tinha apenas um direito de crédito sobre os resultados da empresa, o que os equiparava aos demais credores para fins de responsabilidade. ${ }^{20-21}$

Dá-se destaque para a sociedade medieval (ou em nome coletivo) e para a sociedade em comandita pois alguns elementos presentes nesta figuras societárias contribuíram para a determinação de algumas das feições atuais das sociedades anônimas, que interessam para este estudo.

Não obstante o exposto acima, vale destacar a observação de Goldschmidt:

La 'commenda', base dell'odierna società in accomandita semplice e della società in accomandita per azioni, serve essenzialmente al commercio di speculazione, è in origine principalmente società per affari d'occasione, più tardi anche società industriale, e prima di tutte ha raggiunto un pieno perfezzionamento, si nella consuetudine commerciale che nel diritto statutario. L'odierna società in nome collettivo, più recente della 'commenda', fin dal principio società industriale, ha radice principalmente nell'economia domestica dei membri della famiglia, ma non ha certo preso solo da tale economia i suoi principii giuridici direttivi. La società per azioni finalmente ha radice nelle istituzioni del prestito pubblico e delle colonie. Ciascuna di queste forme principali è sorta indipendientemente dalle altre - la società in accomandita non è storicamente (o dogmaticamente) uma società in nome collettivo modificata, e la società per azioni non è una società in accomandita modificata; - più una volta sorte hanno avuto in varii modi influenza lê une sulle altre;

20 Conforme WARDE JÚNIOR, 2007, p. 73-81. Sobre a limitação da responsabilidade do comanditário e sua equiparação aos demais credores, Warde Júnior, na página 81 da mesma obra: "Como credores, seria injustificado que respondessem, para além da não satisfação dos seus direitos de crédito e do perdimento das entradas fundantes de tais direitos, também com seu patrimônio pessoal."

21 Warde Júnior também salienta outro aspecto que contribuiu para o surgimento das sociedades em comandita. Para os sócios capitalistas, interessados apenas no financiamento da atividade produtiva, atuar meramente como credor do comerciante e receber juros pelo dinheiro emprestado poderia significar descumprimento das regras da Igreja da época, que proibiam a usura e, em última instância, poderia culminar em excomunhão. Sendo assim, ao fazer com que o credor passasse a figurar como sócio do comerciante, a sociedade em comandita acabou se tornando um mecanismo eficiente para burlar as leis que proibiam a usura. Esta observação também é feita por MUNHOZ, 2002, p. 53. 
particularmente l'economia domestica in società ha preso il suo carattere mercantile sotto influenza della commenda, e viceversa la commenda sotto l'azione della società in nome collettivo pienamente sviluppata si è avvicinata a questa, e si trovano sino ai tempi più recenti forme miste e forme intermedie." 22

\subsection{Evolução para as sociedades por ações}

\subsubsection{As companhias colonizadoras}

Como visto anteriormente, as formas societárias existentes na Idade Média, via de regra, estabeleciam a responsabilidade ilimitada do comerciante no exercício da atividade econômica (com exceção da responsabilidade limitada do sócio comanditário na sociedade em comandita). Em vista disso, embora já existisse certa distinção entre a sociedade e seus integrantes, não se pode falar, até este momento histórico, em separação do patrimônio do empresário e da sociedade. ${ }^{23}$

Para Munhoz, durante a Idade Média e até a Revolução Industrial, não obstante a influência das formas societárias descritas acima, a atividade econômica estava centrada no comerciante individual. Embora a economia européia tenha experimentado relevante desenvolvimento em todos os setores, a pequena dimensão das unidades de produção não reclamava outras formas de arranjos societários, pois a economia era essencialmente agrícola, artesanal e mercantil. ${ }^{24}$

22 GOLDSCHMIDT, 1913, p. 201.

23 Conforme Juan M. Dobson: "Las formas asociativas con el objeto de afrontar empresas económicas entre sujetos privados fueron utilizadas profusamente por los comerciantes italianos del medioevo. Estas formas sociales permitían aunar esfuerzos bajo uma dirección común, um patrimônio reunido entre todos o parte de los socios afectado a um objetivo prefijado, de interes también común a todos los asociados. Estas agrupaciones, denominadas 'compagnia', 'societas' y 'commenda' em sus orígenes, admitían uma amplia comunicación de responsabilidad entre los acreedores del grupo y cada uno de los socios." (DOBSON, Juan M. El Abuso de la Personalidade Jurídica. Buenos Aires: Depalma, 1985, p. 1).

24 MUNHOZ, 2002, p. 55. Lamy Filho e Pedreira corroboram a idéia: "Cumpre, todavia, ter presente o limitado alcance de tais formas societárias intuitus personae: o protagonista da atividade mercantil continuava, sem dúvida, a ser o comerciante. Quando formava uma sociedade, ou dela participava, sua presença continuava dominante, o exercício do comércio continuava a ser feito em torno do seu nome, de seu crédito, de seu conceito, de sua presença no negócio. Se a sociedade era em nome coletivo, a solidariedade nas obrigações a todos alcançava. Na comandita, ou na conta de participação, só o sócio solidário aparecia, omitindo-se o nome e a presença do comanditário ou do sócio oculto na vida social. 
Não obstante, antes da Revolução Industrial iniciava-se a formação do modelo societário que hoje é representado pela sociedade anônima, completamente distinto das sociedades em nome coletivo e das sociedades em comandita. "Trata-se das companhias coloniais $^{26}$, constituídas a partir do século XVI, como resposta à necessidade de mobilização de elevadas somas de capital para enfrentar os desafios políticos e econômicos da época dos descobrimentos." 27

Durante a transição da Idade Média para a Era Moderna, deu-se a era dos descobrimentos e a consolidação dos Estados nacionais. A exploração do Novo Mundo e do caminho para as Índias representava não apenas enormes possibilidades de lucros, mas também a luta econômica dos Estados absolutistas para a dominação das novas colônias e para o controle do comércio mundial. Esta empreitada, contudo, requeria investimento de vultosas somas de capitais, além do fato de os riscos associados a tal empreitada terem se tornado muito maiores. Era necessário, portanto, mobilizar capitais "onde quer que pudessem ser encontrados". ${ }^{28}$

A solução encontrada por países como Portugal e Espanha para a exploração das riquezas do Novo Mundo foi a criação do monopólio do Estado para o comércio nascente. A Holanda encontrou solução diversa: a criação de uma companhia colonizadora, que nos interessa por ser apontada pela maioria dos autores como a origem das sociedades por ações. $^{29}$

A Companhia Holandesa das Índias Orientais foi criada em 1602 na Holanda com o objetivo de penetrar e conquistar o Golfo Pérsico e a Indonésia, com algumas prerrogativas de Estado (tais como firmar tratados com príncipes estrangeiros e até mesmo cunhar moeda).

Por isso, a morte do 'chefe da firma' significava, em geral, o desaparecimento da casa mercantil [...]." (1997, p. 27-28).

25 Vide comentário de Goldschmidt indicado anteriormente a respeito da distinção entre a sociedade em nome coletivo, sociedade em comandita e sociedade por ações.

26 A maioria dos autores realmente aponta as companhias coloniais como a origem das sociedades por ações. Não obstante, Lamy Filho e Pedreira (1997) apontam que, antes delas, há outros institutos jurídicos que apresentam alguns precedentes históricos de algumas das características das sociedades por ações, tais como as maone, as rheederein (que podem ser entendidas como precedentes históricos - mas não a origem - da divisão do capital em ações e da livre transferibilidade destas) e das corporações eclesiásticas medievais (que auxiliaram na idéia de existência externa das sociedades e reconhecimento da personalidade jurídica). Para maiores detalhes sobre estes institutos, vide LAMY FILHO; PEDREIRA, 1997, p. 28-30.

27 MUNHOZ, 2002, p. 55.

28 LAMY FILHO; PEDREIRA, op. cit., p. 32.

29 Ibid., p. 32-33. 
A formação do capital da Companhia Holandesa das Índias Orientais era feita mediante contribuição de $\operatorname{só} \operatorname{cios}^{30}$ que, em troca, recebiam um comprovante de sua participação, que podia ser livremente transferido ${ }^{31}$, e que assegurava ao respectivo titular um direito de ação contra a Companhia para haver sua parte no patrimônio comum e nos lucros. $^{32}$

A responsabilidade dos acionistas era, portanto, limitada ao valor de sua contribuição, representada pelo título de participação, na medida em que ele renunciava ao seu direito real sobre as entradas. Os sócios não tinham nenhuma influência sobre a administração da Companhia e, ainda que a administração fosse exercida no interesse dos sócios, este interesse reduzia-se à mera participação nos resultados da atividade econômica. $^{33}$

A estrutura de administração da Companhia Holandesa das Índias Orientais era bastante complexa. Tanto Warde Júnior quanto Lamy Filho e Pedreira apontam que a administração era oligárquica, na medida em que a Companhia era dividida em diversas câmaras, representando determinadas províncias. Cada uma destas câmaras era dotada de grande autonomia e existia, entre tais câmaras, um sistema de créditos e débitos. Este estado permanente de contas recíprocas exigia uma contabilidade complexa e acabou trazendo dificuldades no seu funcionamento. A Companhia contava também com uma

30 “.... admitiu-se o ingresso de quantos desejassem, 'nacionais ou estrangeiros, cristãos ou judeus', sem limitação de qualquer natureza. O objetivo era a participação de 'todos os habitantes das Províncias Unidas', 'com muito ou pouco, segundo desejassem'." (Ibid., p. 33).

31 Warde Júnior aponta que esses títulos de participação podiam ser comercializados na bolsa de Amsterdã (WARDE JÚNIOR, 2007, p. 89). Lamy Filho e Pedreira indicam que a livre circulação das ações, importante para atrair investidores, deu também margem a abusos. Segundo os autores, a bolsa de Amsterdã passou a cotar ações da Companhia Holandesa das Índias Orientais com tal intensidade que apenas sete anos após a fundação da Companhia já havia clamor público contra abusos nas manipulações na bolsa, o que deu causa à sua coibição por meio da promulgação de decretos (1997, p. 34).

32 LAMY FILHO; PEDREIRA, 1997, p. 33. É deste direito de ação que o sócio detinha contra a Companhia para haver dividendos que vem o termo "ação", para representar o titulo de participação no capital social. "O termo ação, azione, action, aktie derivou, segundo Lehmann, do feto de que estes títulos importam justamente em direito (uma 'ação' no sentido próprio do direito processual) aos dividendos." (ASCARELLI, 2001, p. 453).

33 Conforme LAMY FILHO; PEDREIRA, 1997, p. 34; WARDE JÚNIOR, 2007, p. 95. Ainda com Warde Júnior: "Afirmam-se, desta maneira, as sociedades por ações como formas associativas em que todos os membros são privados de uma posição dominial sobre o patrimônio. Não há mais a distinção entre sócios ‘donos' do patrimônio e sócios financiadores. Há apenas uma pluralidade (muitas vezes anônima) de interessados, uma 'pulverização' dos direitos sobre os resultados que os tornam todos externamente responsáveis apenas no limite das suas entradas.” (2007, p. 95-96). 
assembléia geral e um conselho de administração cujos membros, eleitos pelas câmaras, recebiam poderes de administração. ${ }^{34}$

Como dito acima, a responsabilidade dos sócios era limitada às suas entradas, mas o mesmo não se pode dizer dos administradores. Os administradores da Companhia gozavam de vitaliciedade e, como atuavam ainda como "donos do negócio", similarmente aos comerciantes das companhias medievais, não se podia falar ainda em limitação da responsabilidade dos administradores. ${ }^{35}$

Esta situação alterou-se com a criação da Companhia Holandesa das Índias Ocidentais, em 1621. A estrutura desta era bastante similar à da Companhia Holandesa das Índias Orientais, mas seus administradores tinham um mandato de seis anos apenas e amplos deveres de prestar contas aos acionistas. Existia também a obrigação de distribuir lucros e a proibição de contratar com a Companhia, ainda que por intermédio de terceiros. Em vista disso, os administradores "deixaram de ser ilimitadamente responsáveis quando perderam a condição de 'patrões' e passaram a ser mandatários dos acionistas, devido ao tratamento que lhes foi conferido a partir da Companhia das Índias Ocidentais." 36

O modelo das companhias colonizadoras holandesas foi seguido por diversos outros Estados nacionais, e Inglaterra, França, Espanha, Portugal, Suécia e Bélgica constituíram companhias colonizadoras de características semelhantes às holandesas. Um dado importante, e comum a todas estas companhias, é que elas eram criadas pelo Estado e tinham participação dominante deste, que lhes concedia monopólios e outros privilégios, com o objetivo de realizar empreendimentos de interesse vital para o Estado que as criara. $^{37}$

34 LAMY FILHO; PEDREIRA, 1997, p. 33-34; WARDE JÚNIOR, 2007, p. 88.

35 WARDE JÚNIOR, 2007, p. 89. Não obstante, Lamy Filho e Pedreira salientam que o estatuto da Companhia Holandesa das Índias Orientais determinava que os administradores estariam isentos de responsabilidade, e suas propriedades não poderiam ser gravadas ou prejudicadas por ato de administração ou remuneração dos empregados sem que tais questões tivessem sido decididas pelos Tribunais Ordinários. Embora a responsabilidade limitada dos administradores não estivesse aí determinada com clareza, poder-se-ia dizer que se trata de um indício da separação entre os patrimônios do sócio e do administrador (1997, p. 34-35).

36 WARDE JÚNIOR, 2007, p. 89.

37 Conforme LAMY FILHO; PEDREIRA, 1997, p. 35. No mesmo sentido, Ascarelli: "Cada companhia colonial surge com individualidade própria. As companhias coloniais não estão sujeitas a uma disciplina geral, mas encontram, cada qual, seu fundamento numa 'carta' da autoridade pública, pela qual se definem a constituição e a personalidade da companhia, as suas obrigações, os seus direitos, os seus privilégios; às suas obrigações correspondem privilégios e a concessão de monopólios e de direitos que 
Apesar do caráter político das companhias coloniais, nelas já estavam presentes as principais características das atuais sociedades por ações: a criação de ações, títulos representativos da contribuição dos sócios ao capital, a livre transferibilidade das ações e a responsabilidade limitada do sócio ao montante da suas entradas. Foram estas características que interessaram à iniciativa privada, especialmente com a Revolução Industrial.

\subsubsection{A Revolução Industrial e a liberdade de constituição das sociedades anônimas}

Como dito anteriormente, as primeiras sociedades por ações, criadas nos moldes das companhias colonizadoras, eram sociedades compostas por capitais públicos e particulares e destinadas ao cumprimento de objetivos de interesse dos Estados nacionais. Como sua criação dependia de um ato do Estado, diversos autores ${ }^{38}$ denominam esta fase da evolução das sociedades anônimas como fase do privilégio: a criação das companhias era um privilégio concedido pelo Estado. Seus direitos, obrigações, características principais e forma de funcionamento eram determinados no texto legal que as criara, e somente poderiam ser alterados por lei superveniente. ${ }^{39}$

Embora essas sociedades tivessem um intuito específico, o modelo de sociedade anônima criada pelas companhias colonizadoras passou a ser utilizado em outros empreendimentos de interesse geral, como apontam Lamy Filho e Pedreira. Seguradoras, mineradoras, bancos de depósito ou emissão passaram a se organizar sob a forma de sociedades anônimas, mas sempre mediante concessão do Estado e com restrição a apenas algumas determinadas atividades.

simultaneamente abrangem aspectos comerciais e políticos; são, simultaneamente, instrumentos de conquista territorial e de comércio." (2001, p. 455).

38 Dentre os quais podemos citar LAMY FILHO; PEDREIRA, 1997, p. 30-54; MUNHOZ, 2002, p. 57; REQUIÃO, Rubens. Curso de Direito Comercial. 22. ed. São Paulo: Saraiva, 2000, p. 2-6; ASCARELLI, 2001, p. 452-459.

39 Conforme MUNHOZ, 2002, p. 57. 
É de salientar-se que não se fazia, então, ouvir maior reclamo, por parte das forças econômicas, em se assegurarem acesso àquele tipo societário [as sociedades anônimas]. É que, até o fim do século XVIII (antes, pois, da Revolução Industrial) a escala dos empreendimentos era relativamente modesta. ${ }^{40}$

Com a Revolução Industrial, este cenário sofreu sensível alteração. O processo produtivo passou por inúmeras inovações técnicas, tais como: (i) a utilização de novas fontes de energia, como o carvão e o vapor; (ii) o emprego de máquinas na produção em substituição ao trabalho humano; (iii) a descoberta de novas formas de transformar a matéria (ferro e aço, por exemplo); e (iv) a organização do trabalho em grandes unidades centralizadas, com divisão de trabalho eficiente. ${ }^{41} \mathrm{O}$ modelo de sociedade anônima, que permitia angariar vultosas somas de capital para financiar a atividade de exploração do Novo Mundo, passou a ser desejado pela grande indústria em seu processo de produção em massa, "para lhe proporcionar a incorporação de capitais de que tanto tinha necessidade para a sua constante expansão." ${ }^{, 42-43}$

Passou-se, então, da fase do privilégio para a fase da autorização, caracterizada pela flexibilização das exigências para a criação das companhias. Ascarelli e Munhoz apontam como marco inicial desta fase o Code du Commerce francês, de 1807. Segundo os autores, este diploma reconhecia uma disciplina jurídica geral à sociedade anônima, a qual poderia então ser utilizada para a criação de negócios privados lícitos, com prévia autorização da autoridade pública competente. ${ }^{44-45}$

40 LAMY FILHO; PEDREIRA, op. cit., p. 38.

41 Conforme LAMY FILHO; PEDREIRA, 1997, p. 44.

42 REQUIÃO, 2000, p. 4.

43 "A Revolução Industrial colocou os comerciantes diante de problema análogo ao que os grandes descobrimentos - dois séculos antes - haviam criado para as nações: a exigência de capital fixo, com imobilizações sempre mais vultosas. Com a tecnologia em rápido desenvolvimento, a multiplicação das máquinas e a grandeza dos empreendimentos, rompia-se o ciclo comum do giro comercial, exigindo-se mais capital imobilizado com tempo maior de maturação para produzir. [...] Para mobilizar capitais, no volume e nas condições que o exigiam a competição a que estava sujeito, e os grandes empreendimentos que ora se tornavam possíveis (estradas de ferro, indústrias, navegação a vapor, a construção de grandes canais, etc.), voltaram-se os empresários para aquela 'máquina', que começara a ser montada nos Estados na época mercantilista, e que a eles servira tão bem. Passaram, por isso, a reivindicar acesso ao instituto que já se evidenciara tão eficaz na captação da poupança pública.” (LAMY FILHO; PEDREIRA, op. cit., p. 50-51).

44 Cf. MUNHOZ, 2002, p. 58; ASCARELLI, 2001, p. 458.

45 O regime da autorização foi adotado no Brasil com o Código Comercial de 1850. Seu artigo 295 determinava que "As companhias ou sociedades anônimas, designadas pelo objeto ou empresa a que se destinam, sem firma social e administradas por mandatários revogáveis, sócios ou não sócios, só podem estabelecer-se por tempo determinado e com autorização do governo, dependendo de aprovação do corpo 
Na sistemática do Code du Commerce, o regime das sociedades por ações era dualista, prevendo as sociedades anônimas e as sociedades em comandita por ações. As primeiras requeriam autorização prévia da autoridade competente para serem constituídas, as segundas não. Esse sistema dual acabou ensejando grande difusão deste segundo tipo de sociedades $^{46}$ que, segundo Requião, os autores franceses denominaram "febre das comanditas". 47

Após esta experiência ${ }^{48}$, diversos países passaram a adotar legislações determinando a total liberdade de constituição de sociedades anônimas, passando para a terceira fase de evolução das sociedades anônimas, a que os autores denominam fase da liberdade. Munhoz indica que os pioneiros a adotar tal regime foram os norte-americanos, por meio de lei promulgada em 1811. Os norte-americanos foram seguidos pelos ingleses, em 1844, e pelos franceses em 1867, sendo que depois disso o regime da liberdade espalhou-se pela Europa e América Latina. ${ }^{49}$

Finalizando com Requião:

Eis como as sociedades anônimas se tornaram instrumento, e poderoso, de economia capitalista. O curioso, porém, é que estas três etapas históricas privilégio, autorização e liberdade - não importaram, com o surgimento de um sistema, na extinção do sistema anterior. No regime atual da constituição livre das sociedades anônimas - e isso é palpável em nossa própria legislação - a par da regra dominante, persistem ainda os regimes do privilégio e os da autorização. Mantém o direito moderno, ao lado das sociedades livres, as privilegiadas e as

legislativo quando hajam de gozar de algum privilégio; e devem provar-se por escritura pública ou pelos seus estatutos e pelo ato do poder que as houver autorizado". Este dispositivo, todavia, foi derrogado pela Lei $\mathrm{n}^{\circ} 3.150$, de 4 de novembro de 1882 , cujo artigo $1^{\circ}$ dispunha: “Art. $1^{\circ}$. As companhias ou sociedades anonymas, quer o seu objecto seja commercial quer civil, se podem estabelecer sem autorização do Governo."

46 Conforme LAMY FILHO; PEDREIRA, 1997, p. 51-52.

47 REQUIÃO, 2000, p. 4.

48 Lamy Filho e Pedreira apontam que durante a fase da autorização, as sociedades em comandita por ações proliferaram em decorrência da desnecessidade de autorização da autoridade competente para sua constituição. Essa situação, contudo, deu margem a diversos abusos, que foram coibidos por legislação superveniente (op. cit., p. 52). Requião aponta, ainda, a existência de uma convenção firmada entre França e Inglaterra em 1862, segundo a qual as sociedades inglesas poderiam funcionar livremente em território francês. Como na Inglaterra já prevalecia o princípio da livre constituição e funcionamento das sociedades comerciais, inclusive as sociedades anônimas, os empresários franceses, por razões óbvias, passaram a constituir sociedades na Inglaterra para operar em território francês. Em conseqüência, a França publicou, em 1863, uma lei de transição, permitindo que sociedades anônimas cujo capital não excedesse vinte milhões de francos poderiam ser constituídas sem autorização, sendo estas sociedades chamadas impropriamente de sociedades de responsabilidade limitada. (op. cit., p. 5). Para um histórico das companhias coloniais inglesas e a razão pelo qual já vigorava na Inglaterra a liberdade de constituição das sociedades anônimas, vide LAMY FILHO; PEDREIRA, op. cit., p. 35-37.

49 Cf. MUNHOZ, 2002, p. 59. 
autorizadas. Em nosso País, as sociedades anônimas bancárias, de capitalização, de investimentos, as estrangeiras, por exemplo, antes de constituírem umas ou de funcionarem outras, necessitam de carta de autorização concedida pelo poder público. A par dessas, algumas são constituídas especificamente por lei, que lhes traça a estrutura jurídica, com determinados privilégios, como as sociedades anônimas estatais [...]. ${ }^{50-51}$

\subsection{A personalidade jurídica das sociedades anônimas e sua função}

Feitos os comentários sobre a origem e a evolução das sociedades anônimas, faz-se necessário abordar a questão da personalidade jurídica destas sociedades.

Como visto, as primeiras sociedades anônimas eram caracterizadas pela ausência de um sócio titular de direitos reais sobre o patrimônio da sociedade. Os sócios faziam contribuições ao fundo comum da sociedade e, em troca, recebiam títulos representativos de sua contribuição, livremente negociáveis. Os sócios da sociedade anônima tinham o direito de participar dos resultados da empresa, reaver as entradas em caso de dissolução e zelar para que a administração fosse feita de forma a maximizar a geração de lucros aos acionistas.

Warde Júnior observa que esta transferência de bens feita entre o sócio e a sociedade (para a realização da contribuição ao patrimônio comum) não era feita mediante a celebração de um negócio jurídico. O negócio jurídico pressupunha a existência de duas partes, uma para transferir e outra para adquirir a propriedade do bem. No caso da contribuição dos sócios para a formação da sociedade, esta figura do adquirente não existia, na medida em que nenhum dos sócios era titular do patrimônio social.

Sendo assim, surgiu a necessidade de desenvolvimento do conceito de pessoa jurídica. Embora muitas vezes a personalização seja apontada como causa da limitação da responsabilidade dos sócios, viu-se acima que a idéia de responsabilidade limitada foi construída na prática empresarial independente do conceito de pessoa jurídica. O conceito de pessoa jurídica teria, então, a função de

50 REQUIÃO, op. cit., p. 5.

51 Sobre a evolução das fases do privilégio, da autorização e da liberdade nas sociedades anônimas, vide também GALGANO, 2001, p. 146-151. 
[...] prover solução para um problema técnico que - aos olhos dos juristas da época - inviabilizava, em face de cambiantes concepções de direito, a criação e o desenvolvimento das modernas formas societárias de organização da empresa. [...] [O] conceito de pessoa jurídica surge para cumprir uma função que o precede. $^{52}$

Conforme indicado anteriormente, foge ao escopo deste trabalho fazer uma análise detalhada de todas as teorias explicativas da pessoa jurídica ${ }^{53}$. Para os fins deste trabalho, a pessoa jurídica será tratada como um conceito já pacificado no direito brasileiro, adotando a definição de Camargo: "A pessoa jurídica seria, então, uma unidade jurídica de fins próprios e autônomos, com capacidade de adquirir direitos e obrigações, formada por uma organização de pessoas ou bens, com personalidade jurídica atribuída por força de lei."54

Partindo do conceito de pessoa jurídica, dado acima, interessa, para esta dissertação, a análise dos efeitos da personalização e sua função. Muitos dos efeitos analisados aplicam-se a todas as sociedades personalizadas, empresárias ou não. Não obstante, o foco do estudo, como explicitado anteriormente, será a sociedade anônima, exceto quando expressamente ressalvado no texto.

\subsubsection{Constituição de novo sujeito de direito}

A personalização de um ente coletivo lhe confere status de sujeito de direito, titular de direitos e obrigações, e distinto dos membros que o criaram (e isso se aplica a diversos entes personalizados, tais como as fundações e as associações, e não apenas às sociedades anônimas).

${ }^{52}$ WARDE JÚNIOR, 2007, p. 99-100, 103.

53 Além do já citado artigo de Camargo contendo síntese das teorias explicativas da pessoa jurídica, vide também excelente apanhado sobre o tema em WARDE JÚNIOR, 2007, p. 101-129. Rachel Sztajn, em apertada síntese, sustenta que as teorias que procuram explicar ou dar a natureza jurídica da pessoa jurídica são a da ficção, a da equiparação, a orgânica ou da realidade objetiva e a da realidade das instituições jurídicas (SZTAJN, Rachel. Terá a Personificação das Sociedades Função Econômica?. In: PERIN JÚNIOR, Ecio et al. Direito Empresarial - aspectos atuais de direito empresarial brasileiro e comparado. São Paulo: Método, 2005, p. 378). Vide também as considerações de COMPARATO; SALOMÃO FILHO, 2008, p. 319-352.

54 CAMARGO, 2009, p. 293. 
Ao dizermos que a pessoa jurídica constitui um sujeito de direito, vale dizer, distinto de seus sócios, podemos sustentar, como ensina Caio Mário da Silva Pereira, que:

[a] capacidade das pessoas jurídicas é uma conseqüência natural e lógica da personalidade que lhes reconhece o ordenamento legal. Se têm aptidão genérica para adquirir direitos e contrair obrigações, obviamente se lhes deve atribuir o poder necessário, e mais ainda, a aptidão específica para exercê-los." ${ }^{, 55}$

Sendo um sujeito de direito autônomo e com capacidade jurídica conferida pelo ordenamento para a prática de atos necessários à consecução de seus fins, um dos principais efeitos da personalização é a de que o ente personalizado age em nome próprio, e não em nome dos seus sócios, buscando atender seu próprio interesse. ${ }^{56}$

Não obstante, vale destacar que embora a personalização implique em criação de novo sujeito de direito, estes conceitos não se confundem na medida em que nem todo sujeito de direito é dotado de personalidade jurídica. Há certos agregados patrimoniais a que a lei brasileira confere direitos, tais como o espólio e a massa falida, os quais não são dotados de personalidade jurídica. ${ }^{57}$

55 PEREIRA, Caio Mário da Silva. Instituições de Direito Civil. 19. ed. Rio de Janeiro: Forense, 2000. v. I, p. 195.

56 Entes personalizados são constituídos com um escopo específico e todos os atos por ele praticados devem ser direcionados à consecução deste fim. Por isso o ordenamento lhes reconhece a capacidade jurídica, além de outro efeito da personalização que será tratado a seguir: a autonomia patrimonial. "A personificação da sociedade surge, nesse contexto, como técnica que permitiu separar o ente coletivo de seus respectivos membros, transformando-o num sujeito autônomo de direitos e obrigações, com estrutura patrimonial e organizacional independentes, voltado à consecução de um interesse próprio - o interesse social." (MUNHOZ, 2002, p. 68). No mesmo sentido, COMPARATO; SALOMÃO FILHO, 2008, p. 351: "A causa, na constituição das sociedades, deve, portanto, ser entendida de modo genérico e sob uma forma específica. Genericamente, ela equivale à separação patrimonial, à constituição de um patrimônio autônomo cujos ativo e passivo não se confundem com os direitos e as obrigações dos sócios. De modo específico, porém, esta separação patrimonial é estabelecida para a consecução do objeto social, expresso no contrato ou nos estatutos.”. Sendo sujeito de direito distinto de seus sócios (e com patrimônio e objetivos também distintos de seus sócios), a pessoa jurídica possui interesse distinto dos membros que a compõem, e então nos defrontamos com a questão do interesse social. Como foge ao escopo deste trabalho uma análise detalhada da questão do interesse social, vide FRANÇA, Erasmo Valladão de Azevedo e Novaes. Conflito de Interesses nas Assembléias de S.A. São Paulo: Malheiros, 1993. cap. 2 e 3.

57 COMPARATO; SALOMÃO FILHO, 2008, p. 344. 


\subsubsection{Autonomia patrimonial}

A personalização (e isso se aplica a outros tipos societários, não apenas às sociedades anônimas) implica em separação dos patrimônios da pessoa jurídica e dos seus sócios. Significa dizer que a partir da constituição da pessoa jurídica (que deve obedecer às formalidades previstas no ordenamento jurídico), esta se torna sujeito de direito independente dos sócios que a criaram, e as contribuições dos sócios feitas para a constituição da sociedade deixam de pertencer aos sócios e passam a integrar o patrimônio da pessoa jurídica.

Nas palavras de Sztajn:

No que diz respeito às pessoas jurídicas, passando para o plano dos efeitos, importa destacar a divisão afirmativa de ativos, na expressão de alguns, ou seja, o fato de que a barreira criada pela personificação do grupo ${ }^{58}$ impede que credores particulares de seus membros exerçam pretensões creditórias sobre ativos da pessoa jurídica, outro sujeito de direito. ${ }^{59}$

Nas sociedades anônimas, que são o tipo societário que interessa a esta dissertação, não há dúvida que a separação patrimonial entre a sociedade e os sócios seja total, implicando em desvinculação entre os débitos sociais e os bens dos sócios. Não podem, os credores dos sócios, buscar satisfação de seus créditos com os bens sociais, nem podem os credores sociais exigir a satisfação de seus créditos com o patrimônio dos sócios (ausente abuso da personalidade jurídica, como será visto adiante). ${ }^{60}$

58 Apenas para evitar dúvidas, já que a dissertação trata de grupos societários, neste trecho, o termo "grupo" significa o grupo de pessoas que constituiu a pessoa jurídica, sem qualquer referência a grupos de sociedades.

59 SZTAJN, 2005, p. 379.

60 Vale destacar a observação de Fábio Konder Comparato e Calixto Salomão Filho: "Essa separação patrimonial comporta graus, ela não é idêntica e uniforme em todos os casos. Mais acusada nas sociedades anônimas, em que o acionista não responde pelos débitos sociais, apresenta-se, ao contrário, mais atenuada naqueles tipos societários em que uma categoria de sócios, ou todos eles, respondem pelas dívidas da sociedade." (2008, p. 352). 


\subsubsection{Limitação da responsabilidade}

Outro efeito da personalização (intimamente relacionado à capacidade jurídica e à separação patrimonial, e não menos importante) é a limitação da responsabilidade.

Como visto anteriormente, a limitação da responsabilidade surgiu na prática comercial independentemente do conceito pessoa jurídica. No entanto, nos mais variados ordenamentos, a personalidade jurídica conferida a determinados entes coletivos tem como efeito a limitação da responsabilidade dos sócios que a criaram.

Não há dúvida de que este efeito esteja presente nas sociedades anônimas. Entretanto, é importante ressaltar que embora intimamente ligadas, limitação de responsabilidade e personalidade jurídica não são necessariamente coincidentes. No direito brasileiro, há sociedades personificadas com responsabilidade ilimitada (a sociedade em nome coletivo) e sociedades despersonificadas com responsabilidade limitada (a sociedade em conta de participação). ${ }^{61}$

Relembrando as origens das sociedades anônimas com as companhias colonizadoras e o crescimento do emprego destas formas societárias após a Revolução Industrial, temos que as atividades desenvolvidas por estas empresas requeriam vultosas somas de capital que somente poderiam ser financiadas mediante a mobilização da poupança popular. Isso somente se torna viável com a limitação da responsabilidade, pois "se o sócio fosse ilimitadamente responsável pelos débitos sociais, não aceitaria direcionar seus investimentos para a sociedade, sem compartilhar uma parcela considerável do poder de determinar a condução de suas atividades."62

Dado o vulto das operações destas grandes sociedades, evidente que qualquer credor que buscasse a satisfação de seu crédito de qualquer dos sócios (se ausente a responsabilidade limitada) não teria seu crédito satisfeito e possivelmente levaria o sócio em questão à ruína.

61 MUNHOZ, 2002, p. 69.

62 Ibid., loc. cit. 
Além disso, a livre circulação dos títulos representativos da participação no capital da sociedade (e, em conseqüência, a irrelevância do sócio em relação à sociedade), também só pôde ser alcançada por meio da limitação da responsabilidade. ${ }^{63}$

Em suma, embora a limitação da responsabilidade dos sócios não seja uma consequiência da personalização da sociedade, podemos dizer que se trata de um dos efeitos da personalização, e sua importância na prática comercial moderna é incontestável. ${ }^{64}$

\subsubsection{Conclusão: a função da personalização nas sociedades anônimas}

A personalização das sociedades (em especial nas anônimas) resulta em alguns efeitos desejáveis: a criação de um centro de imputação de direitos e obrigações, a autonomia patrimonial e a responsabilidade limitada dos sócios.

É verdade que a obtenção destes efeitos não decorre necessariamente da personalização. Existem agregados patrimoniais que são titulares de direitos embora não tenham personalidade jurídica, há formas societárias onde a separação patrimonial é de certa forma mitigada e existem tanto sociedades despersonalizadas com responsabilidade limitada quanto sociedades personalizadas com responsabilidade ilimitada.

Entretanto, a conferência de personalidade jurídica a determinadas sociedades, em especial às anônimas, garante que todos estes efeitos possam ser alcançados. Em vista disso, adotamos a posição de Comparato e Salomão Filho, segundo a qual "a personalização é uma técnica jurídica utilizada para se atingirem determinados objetivos

63 "Os dois princípios que podemos considerar fundamentais, enquanto deles decorre a maior parte das normas das sociedades anônimas, são o da responsabilidade limitada e o da divisão do capital social em ações. [...] O primeiro princípio não envolve, necessariamente, o segundo, como ressalta a existência das sociedades de responsabilidade limitada. [...] No entanto, o segundo entre os dois princípios, acima mencionados, pressupõe o primeiro, pois a irrelevância da pessoa do sócio só é possível em virtude da responsabilidade limitada dele." (ASCARELLI, 2001, p. 459-461).

64 Elucidativos os exemplos dos benefícios que podem ser trazidos aos sócios em decorrência da responsabilidade limitada em CLARK, Robert Charles. Corporate Law. 13. Imp. New York: Aspen Law \& Business, 1986, p. 8-10. 
práticos - autonomia patrimonial, limitação ou supressão de responsabilidades individuais - não recobrindo toda a esfera da subjetividade, em direito." 65

Nesse sentido, especialmente no que diz respeito às sociedades anônimas, a função da personalização é permitir que sejam atingidos certos objetivos necessários para que a sociedade anônima cumpra com a sua vocação econômica:

[...] a constituição de um instrumento que visa a facilitar o espírito de empreendimento e, ainda, a mobilizar economias de vastas camadas da população; com o objetivo de coletivização do financiamento, de tal modo que, no interesse geral, possa ser incrementado o progresso industrial. Tudo para que se possa ser criada e desenvolvida a grande indústria com suas elevadas inversões em bens instrumentais, os quais, por sua vez exigem capitais de vulto que requerem a cooperação de muitos indivíduos, proporcionando, a seu turno, a possibilidade de cooperar na constituição de uma empresa industrial e participar nos lucros respectivos, mesmo àqueles que não o poderiam fazer direta e pessoalmente." 66

A atividade empresarial envolve risco e isso é da sua essência. ${ }^{67}$ Nas sociedades comerciais, a limitação da responsabilidade dos sócios e a separação patrimonial são mecanismos aptos a mitigar os riscos a que os investidores estariam expostos, especialmente naquelas sociedades dedicadas a atividades onde o investimento é de longo prazo de maturação ou aquelas onde o risco de insucesso é grande. A diminuição do risco a que os sócios estão expostos incentiva o investimento nestas atividades. ${ }^{68}$

Sendo assim, a personalização das sociedades anônimas é um incentivo à participação dos investidores nestas sociedades. Como ensina Guerreiro, a

[...] estrutura e o funcionamento da sociedade anônima somente fazem sentido sob a ótica de um ordenamento jurídico racional e à base do formalismo jurídico que assegure ou propicie a previsibilidade e o cálculo das decisões esperáveis. Se é verdade que o risco constitui pressuposto indissociável da atividade empresarial em um sistema de mercado e livre iniciativa, não é menos certo que as técnicas operativas da sociedade anônima representam um dos mais marcantes momentos da racionalização do Direito, como se pode evidenciar, p. ex., por

65 COMPARATO; SALOMÃO FILHO, 2008, p. 344.

66 ASCARELLI, 2001, p. 461-462.

67 "Em determinados quadros da vida prática, o risco é inerente à própria atividade desempenhada [...]. Assim ocorre no quadro do mundo fático em que se desenvolvem as atividades empresariais." (CASTELLÕES, Leonardo de Gouvêa. Grupos de Sociedades. Curitiba: Juruá, 2008, p. 28).

68 SZTAJN, 2005, p. 383. 
meio da verificação de que a responsabilidade limitada dos acionistas e a separação patrimonial acabam por circunscrever a contingência econômica da empresa, isolando a fortuna pessoal dos sócios de sua má sorte eventual dos empreendimentos organizados sob a forma societária. O edifício jurídico que dá nascimento às companhias e que justifica o seu desenvolvimento no mundo ocidental assenta exatamente sobre tais alicerces e todo o regramento positivo respectivo garante, basicamente, a funcionalidade de um instituto apto a permitir a afetação patrimonial limitada à contribuição dos acionistas ao capital social. ${ }^{69}$

Em vista disso, em posição semelhante à de Comparato e Salomão Filho, Ascarelli sustenta que a personalização é apenas um meio técnico para que os sócios possam exercer a atividade mercantil com responsabilidade limitada. ${ }^{70} \mathrm{E}$ dificilmente poderíamos imaginar o desenvolvimento da economia capitalista, tal como vemos hoje, sem a utilização desta técnica jurídica.

Como salienta Sztajn: "Se a personificação de grupos de pessoas ou conjuntos de bens organizados para determinadas finalidades tem função socialmente desejável, essa função está na segregação de riscos que são indissociáveis da atividade empresarial."71-72

69 GUERREIRO, José Alexandre Tavares. Sociedade Anônima: poder e dominação, RDM, n. 53, p. 72-80, jan/mar 1989, p. 72.

70 ASCARELLI,2001, p. 465.

71 SZTJN, 2005, p. 387. No mesmo sentido, Clark: “What accounts for the corporation's success as a form of organization are its characteristics and a social environment that makes these characteristics useful. For convenience, I will identify four such characteristics: (1) limited liability of investors; (2) free transferability of investors interest; (3) legal personality (entity-atributable powers, life span, and purpose); and (4) centralized management. These four characteristics all serve the positive functions of greatly facilitating the efficient aggregation of very large amounts of capital from numerous investors and the efficient operation of a very large business with numerous owners and employees.” (1985, p. 2).

72 Joaquim P. Muniz enumera, em síntese, algumas justificativas econômicas da limitação da responsabilidade. A primeira delas é a de que a ilimitação da responsabilidade geraria aversão extrema ao risco. Se todas as sociedades fossem de responsabilidade ilimitada, os sócios não investiriam em sociedades que pudessem causar prejuízo. Em decorrência disso, empresas que investissem em novos negócios acabariam tendo estratégias muito mais conservadoras, justamente em decorrência da possibilidade de os sócios responderem com todo seu patrimônio pelos infortúnios empresariais. A ilimitação da responsabilidade também gera desincentivo à diversificação de investimentos, pois quanto maior o número de sociedades de responsabilidade ilimitada de que uma pessoa é sócia, maior a chance de que esta pessoa tenha que responder com seu patrimônio social pelos prejuízos de tais sociedades. Ao contrário, com a responsabilidade limitada, no investimento, por uma mesma pessoa, em diversas sociedades, há redução do risco do investidor, já que suas perdas estariam limitadas ao valor do investimento. A limitação da responsabilidade também reduz os custos de fiscalização da administração social, pois ficando o risco do investidor restrito ao valor de seu investimento, os gastos com o monitoramento da administração social limitam-se apenas ao tanto necessário para evitar a perda do capital investido ou para aumentar o valor dos lucros a serem distribuídos. Na mesma medida, a limitação da responsabilidade limita os custos de um sócio no monitoramento da saúde financeira dos demais sócios, pois não há responsabilidade ilimitada de todos eles pelas perdas sociais. Por fim, a limitação da responsabilidade também facilita a mudança de controle de sociedades ineficientes (na medida em que não se apresenta o caráter intuito personae das sociedades de responsabilidade ilimitada) e evita distorções na avaliação da sociedade, pois nas sociedades de responsabilidade ilimitada cada credor da sociedade pode cobrar seu crédito de qualquer dos sócios ou de apenas alguns deles, de forma que pode 
não se saber de antemão o quinhão de perdas da sociedade com que cada sócio deverá arcar (Cf. MUNIZ, Joaquim P. Princípio da Autonomia Patrimonial e Desconsideração da Personalidade Jurídica. Revista de Direito Empresarial IBMEC, Rio de Janeiro, v. 1, p. 145-170, 2003, p. 147-153). 


\section{CAPÍTULO 2}

\section{GRUPOS DE SOCIEDADES}

\subsection{Primeiras considerações}

\subsubsection{Desenvolvimento do capitalismo e concentração empresarial}

Já foi apontado, no capítulo anterior, que a limitação da responsabilidade dos sócios e a livre circulação das ações foram elementos fundamentais para viabilizar a realização de grandes empreendimentos que requeriam vultosas somas de capital.

Durante o início da Idade Média, quando a produção era mais artesanal e rudimentar, os recursos necessários para o desenvolvimento da atividade mercantil não eram muito elevados. Assim, o comerciante era a figura principal da atividade econômica, suportando os riscos da sua empreitada com todo o seu patrimônio. ${ }^{1}$

Com os descobrimentos, a situação se altera e os recursos de nenhum comerciante individualmente considerado bastariam para a exploração do Novo Mundo. Surgiram as companhias e, com elas, a responsabilidade limitada e a livre circulação de ações. A limitação da responsabilidade do acionista (que não respondia com seu patrimônio pessoal pelas dívidas da companhia) e a livre circulação de ações (que tornou irrelevante a pessoa do acionista frente aos objetivos da companhia) viabilizaram o acúmulo de capitais necessários para a exploração do Novo Mundo. Vale lembrar, contudo, que estes institutos tinham caráter excepcional, haja vista o fato de o Estado exercer grande influência sobre as atividades das companhias, já que elas também tinham objetivos públicos. ${ }^{2}$

1 Lembrando que nestas antigas formas empresariais as atividades eram limitadas e destinadas unicamente a atender as necessidades primárias dos comerciantes, sendo poucos os recursos necessários para o desenvolvimento da atividade empresarial (Conforme LOBO, Jorge. Direito dos Grupos de Sociedades. $R D M$, n. 107, p. 99-122, jul./set. 1997, p. 100).

2 Conforme PRADO, 2006, p. 17-18. 
Com a Revolução Industrial, novas técnicas produtivas que permitiam a produção em larga escala exigiram a comunhão de recursos para grandes concentrações de capitais. O pequeno comerciante individual deu lugar à sociedade comercial. ${ }^{3}$ Especialmente na fase da liberdade (a qual permitia a criação de companhias independente de autorização governamental, como visto anteriormente), a sociedade por ações passou a ser importante mecanismo utilizado para a exploração da atividade econômica privada.

Em decorrência disso, Lobo sustenta que estas sociedades transformaram-se na empresa moderna, que tem como um de seus princípios sua contínua, racional e crescente expansão, com a finalidade de conquistar novos mercados. ${ }^{4}$

Os atributos da moderna sociedade anônima, em especial o seu regramento jurídico, fizeram deste instituto um importante mecanismo de concentração de capital e desenvolvimento do próprio capitalismo. ${ }^{5}$

Antunes destaca, dentre as características das sociedades anônimas que potencializaram esta realidade: (i) a capacidade da sociedade anônima de funcionar como uma "bomba de capital", proporcionando a concentração massiva de capitais, em contrapartida às insuficiências do modelo tradicional da empresa individual, assegurando a continuidade dos recursos financeiros exigidos pela atividade empresária; (ii) o fato de a sociedade anônima institucionalizar estruturas jurídicas de governo empresarial aptas a garantir a separação dos vários poderes organizativos (deliberativos, executivos e fiscalizadores) e a especialização funcional dos fatores do capital ou propriedade (acionistas), da gestão ou controle (administradores, diretores e gerentes) e do trabalho (trabalhadores); e (iii) a personificação e a autonomia patrimonial, que possibilitam a

\footnotetext{
Conforme PRADO, 2006, p. 18.

LOBO, 1997, p. 100.

"Before the twentieth century, most firms were sole proprietorships or partnerships. Sole proprietors and partners are personally liable for the debts of their business. All the owners' assets, not just those invested in the business, are at risk. For example, partner bears full personal liability for the debts of a failed business if the other partners have no assets, even if the business fails through no fault of the partner with the assets. Partnerships have a second problem as well. If one member of a partnership leaves, the entire partnership is automatically dissolved. To continue, the business must form a new partnership. [...] Corporations are companies whose capital is divided into shares that are held by individuals who have only limited responsibility for the debts of the company. That is, a shareholder has limited liability: If the corporation fails (is unable to pay its bills), the stockholders need not to pay for the debts using their personal assets, as shareholders' losses are limited to the price paid for the stock. With limited liability, individuals are more willing to buy shares than they would be if they could lose more than they paid to acquire the shares." (CARLTON, Dennis W.; PERLOFF, Jeffrey M. Modern Industrial Organization. 4. ed. Nova York: Addison Wesley Longman, 2005, p. 13-14).
} 
limitação da responsabilidade, grande vantagem jurídica se comparado ao modelo das empresas individuais. ${ }^{6}$

Desta forma, especialmente durante o século XIX, acentuou-se o fenômeno da concentração empresarial, em que "os vários sectores do mercado aparecem dominados por um número cada vez mais reduzido de grandes empresas monopolísticas."7

Os motivos que podem levar uma empresa a crescer internamente são inúmeros. Para Carlton e Perloff, o principal motivo que justifica este crescimento interno é o aumento da lucratividade, mas diversas outras razões podem ser invocadas, tais como a promoção de eficiências, o aumento de escala a um nível ótimo, a criação de sinergias ou a melhora na administração. ${ }^{8}$

Brealey, Myers e Allen, no mesmo sentido, apontam os motivos que normalmente justificam a concentração de empresas.

O primeiro aspecto mencionado por estes autores é a economia de escala ${ }^{9}$. Como exemplo, eles mencionam que um ano após a fusão da Chevron com a Texaco a consolidação de operações e a eliminação de custos redundantes resultou um corte de custos para as duas empresas de quase dois milhões de dólares. Embora esta vantagem seja mais facilmente observada nas concentrações horizontais (ou seja, naquelas em que as duas empresas pertencem à mesma linha de negócios), também pode ocorrer nas concentrações realizadas em conglomerados (aquelas que envolvem empresas de ramos não relacionados

6 ANTUNES, 2002, p. 34-35.

7 Ibid., p. 34. No mesmo sentido, Dennis W. Carlton e Jeffrey M. Perloff: "The rise of the corporation coincided with the need to increase the size of the firms [...]. The money needed to finance large enterprises could be efficiently raised through the corporate form of organization. Otherwise, investors were not willing to accept the potential liabilities arising from the actions of the managers whom they neither knew or had the ability to monitor." (2005, p. 14).

8 "Combining firms may reduce duplication or produce other benefits from increased size. For example, the firms may be able to save management costs by using a single set of managers to run both firms. As the costs of factors of production change, the optimal size of a firm (that is, the output at which average cost is minimized) may increase. [...] Reduced transaction costs could explain why two firms that engage in different activities might prefer to merge. [...] Firms that engage in different but complementary activities may benefit from mergers because of synergies or economies of scope: It is less costly for one firm to perform two activities than for two specialized firms to perform them separately. [...] Acquiring a badly run firm and installing better management produces gains." (CARLTON; PERLOFF, op. cit., p. 20-21).

9 Ocorre quando o custo unitário médio da produção diminui à medida que o volume da produção aumenta. 
entre si). Neste último caso, as economias de escala normalmente provêem da partilha de serviços centrais, tais como a contabilidade, o controle financeiro, a gestão de topo, etc. ${ }^{10}$

No caso das concentrações verticais (aquelas envolvendo empresas que atuam em estágios diferentes do processo produtivo), é a integração vertical que traz vantagens para as empresas consolidadas. O crescimento da empresa é feito de forma a integrar diferentes estágios da cadeia produtiva em uma única empresa, geralmente por meio da incorporação de fornecedores e distribuidores. Essas medidas têm o condão de facilitar a coordenação e a administração das atividades da empresa, além de permitir a redução de custos de transação. ${ }^{11-12}$

Para Damodaran, um dos principais motivos para a concentração de empresas é a criação de sinergias, operacionais ou financeiras. Sinergias operacionais são aquelas que "allow firms to increase their operating income, increase growth, or do both." Para este autor, as sinergias operacionais podem ser de quatro categorias: (i) economias de escala, que permitem às empresas combinadas ser mais eficientes e rentáveis, (ii) maior poder de mercado, em decorrência da diminuição da concorrência e do mercado relevante, resultando em maiores margens e receitas operacionais, (iii) combinação de diferentes forças funcionais, como é o caso exemplificativo de firma com grande habilidade de marketing que adquire uma empresa com boa linha de produtos, e (iv) maior crescimento no mercado, que ocorre, por exemplo, quando uma empresa de produtos destinados ao

10 BREAKLEY, Richard A.; MYERS, Stewart C.; ALLEN, Franklin. Princípios de Finanças Corporativas. Trad. Maria do Carmo Figueira e Nuno de Carvalho. 8. ed. São Paulo: McGraw-Hill Interamericana do Brasil, 2008, p. 774-777.

11 Ibid., p. 777.

12 Sobre os custos de transação, uma elucidadora síntese: "Quando indivíduos impõem custos ou oferecem benefícios para outros, mas não têm incentivo econômico para levar em conta estes custos ou benefícios, os economistas dizem que a situação inclui externalidades. [...] Constatamos que uma das principais fontes de falha de mercado são ações que criam efeitos colaterais que não são devidamente levados em conta, isto é, externalidades.. [...] [M]esmo na presença de externalidades, uma economia sempre pode alcançar uma solução eficiente desde que os custos de fazer uma transação sejam suficientemente baixos. Os custos de chegar a uma troca ou um acordo de compra ou de venda são conhecidos como custos de transação. [...] Contudo, em muitas situações envolvendo externalidades, os custos de transação impedem os indivíduos de fazerem transações eficientes. Exemplos de custos de transação incluem os seguintes: (i) custos de comunicação entre as partes interessadas, custos que podem ser muito altos se há muitas pessoas envolvidas, (ii) custos de fazer acordos cujo cumprimento seja obrigatório por lei, custos que podem ser altos se for preciso contratar advogados que cobram muito, (iii) atrasos custosos por causa da barganha, mesmo que a transação seja potencialmente benéfica para ambos os lados, cada lado pode resistir, em um esforço para extrair termos mais favorábeis, levando ao aumento dos esforços e de utilidade que deixa de ser usufruída. Em alguns casos, as pessoas encontram formas de reduzir os custos de transação, permitindo que elas internalizem as externalidades." (KRUGMAN, Paul; WELLS, Robin. Introdução à Economia. Trad. Helga Hoffmann. Rio de Janeiro: Elsevier, 2007, p. 394-399). 
consumo adquire uma renomada rede de distribuição e usa esta expertise para incrementar suas vendas. ${ }^{13}$

Recursos complementares também justificam a concentração empresarial. Num claro exemplo:

\begin{abstract}
A pequena empresa pode ter um produto realmente único, mas não ter os recursos de engenharia e comercialização que seriam necessários para produzi-lo e comercializá-lo em larga escala. A empresa pode desenvolver esses recursos internamente, partindo do zero, mas talvez seja mais rápido e mais barato realizar uma fusão com uma empresa que já detenha amplo talento nesses domínios. [...] Além disso, a fusão pode abrir oportunidades que nenhuma das empresas individualmente conseguiria aproveitar. ${ }^{14}$
\end{abstract}

Outro argumento a favor das fusões entre empresas são fundos excedentes. Empresas com excedentes de caixa que não aumentam a distribuição de dividendos nem reinvestem o capital podem ser alvo de empresas que se propõem a gerir melhor o capital. Além disso, o excedente de caixa não é o único recurso que pode ser desperdiçado com uma má gestão. Uma empresa mais eficiente que adquire outra pode eliminar ineficiências das mais variadas naturezas na empresa adquirida. ${ }^{15}$

Com as sinergias financeiras, "the payoff can take the form of either higher cash flows or a lower cost of capital (discount rate)." Damodaran cita alguns exemplos: uma sociedade com elevado fluxo de caixa e poucas oportunidades de projetos e uma empresa com projetos altamente rentáveis, mas com caixa limitado, podem funcionar melhor se combinadas, na medida em que o excesso de caixa de uma pode viabilizar a realização de projetos da outra que de outra maneira não seriam viáveis. Além disso, duas empresas combinadas podem viabilizar o aumento da capacidade de endividamento da empresa resultante na medida em que suas receitas e fluxos de caixa podem ser mais estáveis e previsíveis, diferentemente do que ocorreria com as empresas individualmente consideradas. Por fim, a consolidação de empresas pode trazer benefícios fiscais na medida

13 DAMODARAN, Aswath. Investment Valuation. 2. ed. New York: John Wiley \& Sons, 2002, p. 695.

14 BREALEY; MYERS; ALLEN, 2008, p. 778.

15 Ibid., p. 778-779. No mesmo sentido: "Some firms are not managed optimally, and other individuals often believe they can run them better than the current managers. Acquiring poorly managed firms and removing incumbent management, or at least changing existing management policy or practices, should make these firms more valuable, allowing the acquirer to claim the increase in value." (DAMODARAN, 2002, p. 696-697). 
em que prejuízos operacionais podem ser utilizados para reduzir impostos pagos com base na receita das empresas, por exemplo. ${ }^{16}$

Em suma, o movimento de concentração empresarial que se verificou ao longo do processo de desenvolvimento do próprio capitalismo explica-se por diversos motivos, alguns dos quais listados anteriormente. O que se verifica é que as empresas concentram-se quando a consolidação de atividades representa vantagens para todas as partes envolvidas, pois do contrário a concentração não ocorreria.

Ocorre que, em certos momentos e em dadas circunstâncias, a consolidação dos agentes econômicos pode não ser a opção mais vantajosa para as partes. É nesse sentido que se deu a chamada "inversão do movimento concentracionista".

\subsubsection{Inversão do movimento concentracionista: os grupos societários}

O movimento concentracionista das empresas começou, segundo Prado, no final do século XIX, por meio de fusões e aquisições. Essas operações societárias eram motivadas, muitas vezes, pelas razões descritas no tópico anterior, e resultavam no crescimento interno das estruturas empresariais. Entretanto, o crescimento excessivo destas estruturas ocasionou complexos problemas organizacionais e de gestão, decorrentes da formação de sociedades gigantescas. ${ }^{17}$

Como indicam Carlton e Perloff,

The higher the costs of doing business with other firms, the more tasks a firm performs itself. [...] Although a firm may want to grow so as to avoid the cost of doing business with other firms, a larger firm faces higher costs and great difficulty monitoring its own managers and employees so as to ensure that they operate efficiently and profitably. The optimal size of a firm depends on this trade-off between the advantages and disadvantages of expanding. "18

16 DAMODARAN, 2002, p. 696.

17 Conforme PRADO, 2006, p. 18.

18 CARLTON; PERLOFF, 2005, p. 18-19. 
Brealey, Myers e Allen sustentam que atualmente a "onda" de integração vertical parece estar esmorecendo, pois as empresas notaram que em muitos casos a integração pode não ser o caminho mais eficiente. ${ }^{19}$ Em decorrência disso, uma das alternativas encontradas pelos empresários foi a adoção de uma nova técnica de organização da empresa. A concentração empresarial deu lugar à expansão externa da empresa, "mediante a aquisição do bloco de controle de outras sociedades, formando os grupos societários."

Baptista, no mesmo sentido, afirma que ao final do século XIX e especialmente após a Segunda Guerra Mundial verificou-se uma concentração crescente do capital, que ignora fronteiras políticas e determina a formação de oligopólios. Este processo fomentou a diversificação das atividades produtivas por meio da reunião, em agrupamentos ${ }^{21}$, de várias outras empresas menores. $^{22}$

Assim, os grupos societários surgiram como resultado de uma nova estratégia de crescimento da empresa $^{23}$, não apenas como resultado da concentração empresarial, mas também como técnica de descentralização de atividades de uma empresa que atingiu tamanho excessivo, ou que, por razões de dispersão geográfica ou especialização, requer a criação de sujeitos jurídicos separados, mas sem prejuízo da unidade econômica. ${ }^{24-25}$

19 "Por exemplo, nas décadas de 1950 e 1960, pensava-se que a General Motors tivesse uma vantagem de custo em relação aos concorentes Ford e Chrysler, porque uma maior parte das peças usadas na GM eram de produção própria. Na década de 1990, eram a Ford e a Chrysler que tinham a vantagem de custo: conseguiam comprar mais barato de produtores independentes. Isso se deve, em parte, ao fato de essas empresas externas terem a tendência para usar pessoal não sindicalizado e para pagar salários mais baixos." (BREALEY; MYERS; ALLEN, 2008, p. 777).

20 PRADO, 2006, p. 18.

21 Luiz Olavo Baptista prefere utilizar a expressão "agrupamento de sociedades" para designar a situação de fato onde se verificam empresas agrupadas, para distinguir a situação de fato da situação de direito, que consiste nos grupos de sociedades propriamente ditos. Mais adiante será abordada a distinção entre grupos de fato e grupos de direito.

22 Luiz Olavo Baptista, comentando o Cap. XXI da Lei das Sociedades por Ações em VIDIGAL, Geraldo de Camargo; MARTINS, Ives Gandra da Silva (Coords.). Comentários à Lei de Sociedades por Ações. Rio de Janeiro: Forense, 1999, p. 840.

23 Muito embora o fenômeno da concentração de empresas possa ser verificado em larga escala a partir do final do século XIX, vale destacar o trabalho de Comparato que indica que o Banco Medici de Florença criou o primeiro caso histórico de grupo societário - e multinacional - de que se tem notícia. Após sua liquidação, no século XV, a experiência de agrupamentos de empresas foi praticamente abandonada no Ocidente, sendo retomada apenas muitos séculos depois (COMPARATO, Fábio Konder. Na ProtoHistória das Empresas Multinacionais: o Banco Medici de Florença. In: Direito Empresarial, São Paulo: Saraiva, 1995 , p. 261).

24 FUENTES NAHARRO, Mónica. Grupos de Sociedades y Protección Acreedores (Una Perspectiva Societária), Navarra: Thomson Civitas, 2007, p. 42. No mesmo sentido: "É possível identificar duas principais fases no movimento concentracionista. A primeira [...] consiste num crescimento da dimensão da empresa, pela absorção das unidades, reduzindo-se o seu número. A partir do momento em que o gigantismo ameaçou suplantar os benefícios desta expansão, desenvolveu-se outro tipo de expansão, através das coligações, aquisições de controle de outras sociedades e acordos entre concorrentes. Esta 
A própria estrutura jurídica das sociedades por ações favoreceu a criação dos grupos de sociedades. Comparato aponta que a personalidade jurídica da sociedade por ações, distinta de seus sócios, assegurou a autonomia patrimonial da sociedade e a multiplicação dos centros de imputação das relações jurídicas. O mecanismo da participação acionária, por sua vez, garantiu o poder de comando sobre diferentes patrimônios. Com isso, como conclui Comparato, obteve-se o controle sem o ônus da propriedade e o poder sem o risco. ${ }^{26}$

Os motivos mencionados pela doutrina que justificam a criação de grupos de sociedades em oposição à concentração empresarial são os mais variados, mas sua justificativa é quase sempre econômica. ${ }^{27}$ Afinal, como diz Arriba Fernandez, "Los grupos, en sí, no son ni buenos ni malos; son eficientes ecónomicamente. En otras palabras, los grupos son fenómenos de reorganización empresarial."28 Abaixo, em breves linhas, alguns desses motivos são listados de forma sistematizada.

segunda fase caracteriza-se pela integração das sociedades num agrupamento, subordinado à mesma direção econômica. Nesta última configuração, [...] se estabelece uma verdadeira comunhão de bens e interesses, com a definição, de fato ou de direito, da centralização do poder para dirigir as divesas sociedades." (WALD, Arnoldo. Caracterização do Grupo Econômico de Fato e Suas Consequiências quanto à Remuneração dos Dirigentes de Suas Diversas Sociedades Componentes. Revista de Direito Bancário e Mercado de Capitais, n. 25, p. 145-161, jul./set. 2004, p. 147). Vide também WALD, Arnoldo; EIZIRIK, Nelson. A Designação "Grupo de Sociedades" e a Interpretação do art. 267 da Lei das S/A. RDM, n. 54, p. 51-66, 1984, p. 55-57.

25 Melvin Aron Einsenberg exemplifica o parágrafo acima: “For example, 24 of the country's [os Estados Unidos da América] 25 largest commercial-banking institutions, including all 10 of the very largest Bank of America, First National City, Chase Manhattan, J. P. Morgan, Manufactures Hanover, Chemical, Bankers Trust, Western Bancorporation, Continental Illinois, and First Chicago - are either megasubsidiaries or holding companies whose banking business is done through one or more megasubsidiaries." (EINSENBERG, Melvin Aron. The Structure of the Corporation - a legal analysis. Washington, DC: BeardBooks, 2006, p. 277).

26 COMPARATO, 1976, p. 195.

27 "There are a plethora of reasons for adopting such a structure. Some examples are reduced tax liability, accounting considerations and greater flexibility when rising capital or debt finance. Two features of the corporate group that make it particularly attractive are: (i) organizational flexibility which facilitates allocative and productive efficiency; and (ii) minimized liability by insulating assets of one part of the business from claims arising from activities being conducted in other parts." (BICKER, Eike Thomas. Creditor protection in the Corporate Group. July 2006. Disponível em: <www.ssrn.com/abstract=920472>. Acesso em: 29 dez. 2010, p. 2.

28 ARRIBA FERNÁNDEZ, María Luisa de. Derecho de Grupos de Sociedades. Madrid: Civitas, 2004, p. 34. 


\subsubsection{Razões para a formação de grupos de sociedades}

\subsection{Diminuição do risco}

Galgano ensina que o principal objetivo da formação de um grupo é a separação do risco relativo a um determinado setor ou mercado. Cada sociedade do grupo é, frente a terceiros, um sujeito de direito independente das outras sociedades do grupo e, desta forma, não responde pelos débitos das demais empresas integrantes do grupo. $\mathrm{O}$ benefício da responsabilidade limitada passa a ter outro significado para a empresa controladora do grupo: não se trata apenas de separar o patrimônio da sociedade e o do acionista, mas sim separar o risco inerente a diversos setores ou mercados, uma vez que a sociedade controladora responderá apenas no limite do capital investido na sociedade controlada. ${ }^{29}$

Como ensinam Hansmann e Kraakman:

[L]imited liability permits firms to isolate different lines of business for the purpose of obtaining credit. By separately incorporating, as subsidiaries, distinct ventures or lines of business, the assets associated with each venture can conveniently be pledged as a security just to the creditors who deal with that venture. Those creditors are commonly well positioned to assets and keep track of the value of those assets, but may have little ability to monitor the corporations' other ventures. Finally, by virtue of limited liability, the formation of corporations and subsidiary corporations can be used as means of sharing risks of transactions with the parties whom a firm contracts, in situations in which the latter parties are in a better position to bear those risks. ${ }^{30}$

A característica descrita acima resultou num importante instrumento para a expansão dos negócios empresariais já que, nos grupos de sociedades, as empresas grupadas são economicamente dependentes da sociedade de comando, mas juridicamente independentes umas das outras. ${ }^{31}$

29 GALGANO, 2001, p. 165-166.

30 KRAAKMAN, Reinier R. et al. The Anatomy of Corporate Law. New York: Oxford University, 2006, p. 9.

31 Cf. PRADO, 2006, p. 41. Aliás, é justamente este aspecto que diferencia a criação de grupos de sociedades da fusão e incorporação de empresas. Na fusão e na incorporação, há unidade econômica $e$ jurídica entre as empresas. 
2.1.2.1.2 Mobilidade da estrutura empresarial

Além da notória redução do risco envolvido no desenvolvimento da atividade empresarial, a criação de grupos de sociedades, em detrimento de uma concentração empresarial com expansão interna da empresa, garante mobilidade da estrutura empresarial.

Os investimentos podem ser feitos conforme a oportunidade de negócio, mediante simples aquisição de ações ou quotas da sociedade "filha". Da mesma maneira, o desinvestimento em um determinado setor não mais atrativo em um dado momento econômico é feito mediante mera alienação da participação societária detida na sociedade controlada. $^{32}$

\subsection{Flexibilidade da organização empresarial}

Outro aspecto, que leva as empresas a se organizarem em forma de grupos, a flexibilidade da organização empresarial, é decorrente da vantagem descrita no item anterior.

À medida em que as sociedades integradas em grupos mantêm sua autonomia jurídica, estas empresas constituem centros produtivos autônomos. Com este mecanismo, as sociedades controladas mantêm organização interna própria, ainda que sob uma direção unitária da sociedade de comando.

Esta estrutura favorece, dentre outras situações, a atuação internacional da sociedade, que pode estabelecer sociedades controladas em outros países onde as políticas

32 PRADO, 2006, p. 42. No mesmo sentido, Antunes: "Por outro lado, trata-se de uma técnica que permite criar para a organização da actividade econômica da empresa uma estrutura extremamente maleável e flexível. Na verdade, no grupo de sociedades não estamos atidos a uma ou duas formas legais, como na fusão, mas a quantas a imaginação do empresário originar [...]. De resto o grupo é uma técnica suficientemente elástica para permitir constantes reajustamentos da estratégia e acção do grupo às condições do seu meio económico envolvente.” (2002, p. 64-65). 
globais de grupo são desenvolvidas de forma adaptada à legislação local. ${ }^{33}$

Este aspecto, da flexibilidade e mobilidade da estrutura empresarial obtidas por meio da estrutura de grupo, foi observado também por Galgano:

\begin{abstract}
Le 'multinazionali' o 'transnazionali' presentano questa struttura: esse danno luogo ad una proliferazione di società, tanti quanti sono i mercati esteri nei quali l'impresa opera, tutte controllate della società nazionale. Si consegue cosi il vantaggio di separare fra loro i rischi del mercado estero da quelli del mercato nazionale e, inoltre, di separare fra loro i rischi relativi a ciascuno dei mercati esteri. E si consegue l'ulteriori vantaggio di poter dislocare diverse società di gruppo em paese opportunamente scelti, in rapporto allá convenienza che ciascuno di essi offre sotto i diversi aspetti delle risorse materiali o del costo del lavoro o del mercato dei capitali o del trattamento fiscale. ${ }^{34}$
\end{abstract}

2.1.2.1.4 Redução dos custos de transação

As opções de organização da empresa buscam sempre a diminuição dos custos de transação. A simples aquisição de participação societária em uma empresa geralmente representa investimentos muito menores se comparados àqueles destinados à implantação, “do zero", de uma nova atividade ou da expansão interna dos negócios de uma sociedade. ${ }^{35}$

A questão dos custos de transação já foi brevemente mencionada quando se tratou das razões que levaram ao movimento concentracionista das empresas. Coase foi o primeiro autor a chamar atenção para o fato de que custos de transação - ou seja, os custos incorridos pelas partes para a conclusão de uma dada transação no mercado - influíam para determinar se tal operação seria concluída dentro da própria empresa ou no mercado. Para este autor, "The existence of transaction costs will lead those who wish to trade, to engage in practices which bring about a reduction of transaction costs whenever the losses

33 PRADO, 2006, p. 42-44.

34 GALGANO, Francesco. Le Società - I Gruppi di Società. Turim: UTET, 2001, p. 15.

35 PRADO, op. cit., p. 42-43. 
suffered in other ways from the adoption of these practices is less than the transaction costs saved." 36

Em outras palavras, pode ser mais custoso desenvolver determinadas atividades dentro de uma única e grande empresa (com altos custos de manutenção e administração) que contratar as mesmas atividades com empresas distintas, especialmente se tais empresas estão unidas por uma direção unitária. É nesse sentido que a adoção de uma estrutura de grupo pode reduzir custos de transação.

Se os custos de transação são mais baixos quando se realiza a transação sob uma estrutura hierárquica, ela é localizada dentro da empresa; se, pelo contrário, a transação pode ser feita a baixo custo por meio de uma relação relativamente anônima, como as que ocorrem no mercado, é lá que ela deve estar. ${ }^{37}$

Vale destacar que a opção pela concentração ou formação de um grupo para a redução dos custos de transação é dependente do momento histórico, do mercado em questão, da legislação vigente, entre outros aspectos. Em vista disso, em um dado momento a opção pela concentração pode ser a mais interessante e, num segundo momento, pode não mais o ser. Como ensinam Pinheiro e Saddi:

É obvio que os custos de transação em uma alternativa e outra dependem diretamente de instituições como a Lei, e, portanto, a fronteira ótima da empresa - em que se localizam as transações que custam quase o mesmo se realizadas dentro ou fora da empresa - pode variar de uma jurisdição para outra, ou de uma época para a outra em uma mesma jurisdição. ${ }^{38}$

É por isso que Coase sustenta que: "The limit to the size of the firm is set where its costs of organizing a transaction become equal to the cost of carrying it out through the market." 39

36 COASE, Ronald H. The Relevance of Transaction Costs in the Economic Analysis of Law. In: PARISI, Francesco; ROWLEY, Charles (org.). The Oorigins of Law and Economics - Essays by the Founding Fathers. Cheltenham: The Locke Institute, 2005. p. 199-221, p. 202.

37 PINHEIRO, Armando Castelar; SADDI, Jairo. Direito, Economia e Mercados. Rio de Janeiro: Elsevier, 2006, p. 68-69.

38 Ibid., p. 69.

39 COASE, op. cit., p. 203. 
2.1.2.1.5 Redução do investimento inicial de capital

Como aponta Antunes, os grupos societários constituem um grande atrativo aos empresários na medida em que permitem assegurar o controle de uma enorme massa de capitais e a direção econômica de numerosas sociedades com um investimento inicial muito reduzido.

Este fenômeno é obtido quando se consideram as participações societárias em cascata (desencadeando um efeito conhecido como capital leverage). Utilizando-se desta estratégia, os empresários podem ter o controle de diversas sociedades com um investimento inicial relativamente reduzido, e imprimir a todas as sociedades controladas uma direção unitária. ${ }^{40}$ Tem-se então a atuação uniforme de diversas empresas, com um investimento necessário apenas para o exercício do controle na sociedade dominante.

\title{
A situação é exemplificada por Comparato:
}

\begin{abstract}
A situação é muito delicada naquelas companhias criadas para controlar outras (holding corporations), e cujos fundos sociais são, portanto, constituídos, na sua maior parte, por ações. Suponha-se uma companhia com o capital de 1.000.000, sendo 550.000 possuídos por outra, cujo capital de 600.000 , por sua vez, é controlado a $60 \%$, ou seja, 360.000 por outra companhia com o capital de 400.000. Em tal hipótese, a detenção de mais da metade do capital desta última, isto é, de um pouco mais de 200.000 ações, permitirá, através do controle em cadeia, dispor de uma companhia com o capital de um milhão e, certamente, com fundos sociais de valor mais elevado. ${ }^{41}$
\end{abstract}

Como as formas de organização dos grupos são inúmeras, as razões para a sua constituição também o são. O propósito deste item foi fazer um breve apanhado dos principais motivos que levam ao surgimento dos grupos de sociedades, e não uma análise exaustiva de cada um deles ${ }^{42}$.

ANTUNES, 2002, p. 66-67.

COMPARATO, 1970, p. 80.

42 Para algumas observações um pouco mais detalhadas a este respeito, vide ANTUNES, op. cit., p. 63-71. Vide também o tópico "Reasons for Corporate Groups" em RAMSAY, Ian M. Allocating Liability in Corporate Groups: an Australian perspective. Disponível em: <www.ssrn.com/abstract=1024901>. Acesso em: 30 maio 2008, p. 338-341. 
Feitas estas primeiras considerações sobre o surgimento dos grupos de sociedades na realidade econômica, passa-se agora à análise de suas principais características.

\subsection{Conceito e características dos grupos de sociedades}

A doutrina jurídica não é pacífica em conceituar os grupos de sociedades ou em determinar os elementos que os caracterizam. Como bem salienta Antunes,

[...] o grupo societário constitui uma dessas realidades de charneira entre o mundo jurídico e o mundo económico para a qual a doutrina não encontrou ainda uma definição pacífica e uniforme, não faltando mesmo quem haja já sustentado que 'é ilusório pensar na possibilidade de se encontrar um conceito global de grupo de sociedades'. ${ }^{43}$

Os conceitos encontrados na doutrina são os mais variados ${ }^{44}$ e não é difícil compreender a razão desta grande divergência. A constituição de grupos de sociedades não é, normalmente, objeto de disciplina jurídica imperativa que determina suas formas de constituição e operação. ${ }^{45}$

43 ANTUNES, 2002, p. 51-52.

44 "El grupo de sociedades puede definirse como la integración de várias sociedades juridicamente independientes bajo una dirección unitária." (ARRIBA FERNÁNDEZ, 2004, p. 84). "On appelle 'groupe de sociétés' l'ensemble constitué par plusieurs sociétés, ayant chacune le leur existence juridique propre, mais unies entre elles par des liens divers en vertu desquels l'une d'elles, dite société mère, qui tient les autres sous sa dépendance, exerce un contrôle sur l'ensemble et fait prévaloir una unité de décision." (CHARVÉRIAT, Anne et al. Mémento Practique Francis Lefebvre - Groupes de Sociétés. Levallois: Francis Lefebvre, 2006, p. 15). "Corporate groups are multi-company structures dominates by 'controllers', or powerful insiders, who may be the shareholders of a dominant company, coalitions of shareholders, or even cliques of influential managers." (KRAAKMAN et al, 2006, p. 75). "La figura che domina la scena dell'a economia contemporanea è quella del gruppo di società, operante sotto il controllo di una 'società-madre' o 'società capo-gruppo': a ciascuna delle società che compongono il gruppo corrisponde, quale oggesto sociale, un distinto settore di attività, o una distinta fase del processo produttivo, o una distinta forma di utilizzazione industriale di una medesima sostanza base, e via dicendo; ma le azioni do ciascuna di queste società appartengono, in tutto o in maggioranza, ad un'ulteriore società, la società-madre o capo-gruppo, detta ache società holding, alla quale spetta, perció, la direzione dell'intero gruppo ed all'interno della quale $i$ vari settori o frammenti sono coordinate e ricondotti ad unitá." (GALGANO, 2003, p. 13-14). Nota-se, em todas as definições descritas acima, a presença de um elemento comum: a direção unitária.

45 Ressalvadas as regras específicas relativas à constituição de grupos de sociedades previstas em alguns ordenamentos, tais como o alemão, o brasileiro e o português. Nem mesmo nestes ordenamentos a regulamentação é exaustiva, contudo. 
Na medida em que a criação de grupos de sociedades é, mormente, resultado da imaginação dos empresários frente às necessidades econômicas, e não decorrência da escolha de um determinado tipo legal pré-determinado, a variedade de tipos e formas de grupos de sociedades existentes pode tender ao infinito. ${ }^{46}$

Em vista da existência diversos tipos de formas de grupos societários, apresentamse, na doutrina, os mais variados critérios para a caracterização e classificação dos grupos de sociedades. Esses critérios de classificação levam em consideração aspectos como a estrutura hierárquica ou paritária das empresas grupadas, a forma de organização das sociedades que compõem o grupo, o ramo de atividade das sociedades, a identidade de membros da administração, entre outros.

A seguir são apresentados os principais critérios de classificação dos grupos de sociedades na doutrina especializada.

\subsubsection{Classificação dos grupos de sociedades}

Se várias são as formas em que os grupos de sociedade podem ser constituídos, também são inúmeras as suas possibilidades de classificação.

Antunes, num esforço de identificar as principais formas de classificação dos grupos de sociedades ${ }^{47}$, destaca as seguintes: (i) grupos de direito e grupos de fato; (ii) grupos de subordinação e grupos de coordenação; (iii) grupos de base societária, contratual ou pessoal; e (iv) grupos industriais, financeiros e mistos.

A classificação descrita, a seguir, não é exaustiva e nem mesmo "pura", na medida em que muitas vezes um mesmo grupo, quando observado na realidade fática, pode ser enquadrado em distintos critérios de classificação.

Las clasificaciones que aquí ofrecemos no tienem ánimo de exhaustividad; se

46 ANTUNES, 2002, p. 72.

47 Ibid., loc. cit. 
trata simplemente de brindar una panorâmica general sobre la fenomenologia de los grupos afín de lograr un mejor conocimiento de tan particular figura. Eso sí, siendo conscientes de que los esquemas clasificatorios rara vez se presentan con toda pureza en la realidad. De tal modo que, para lograr una adecuada visión de los grupos de sociedades, será necesario superponer diferentes clasificaciones. No olvidemos que cada grupo es un microcosmo particular y que, en consecuencia, hay tantos tipos de grupos como grupos existen en la realidad. ${ }^{48}$

\subsubsection{Grupos de fato e grupos de direito}

O critério de classificação que distingue grupos de fatos dos de direito é baseado na existência ou não de um instrumento jurídico que determine a constituição do grupo e de um regime jurídico específico a ele aplicável. ${ }^{49}$

As particularidades do regime aplicável aos grupos de direito, nos ordenamentos que o prevêem, variam conforme o caso. Entretanto, uma característica essencial é comum a estes regramentos: a criação de um grupo de direito resulta na aplicação, a este mesmo grupo, de um regime jurídico excepcional que permite derrogar alguns dos principais cânones do direito das sociedades. Este regime excepcional legitima o exercício do poder de direção da sociedade de comando do grupo sobre as demais sociedades grupadas e a subordinação do interesse destas últimas aos interesses do grupo. ${ }^{50}$

A definição dos grupos de fato é feita pela negativa. Sendo os grupos de direito aqueles formados mediante instrumento jurídico expressamente previsto no ordenamento para tal finalidade, os grupos de fato são aqueles nos quais a direção unitária e a subordinação dos interesses das sociedades grupadas aos interesses do grupo são definidas por outros instrumentos, tais como acordos parassociais, contratos interempresariais, relações econômico-fáticas de dependência e - talvez principalmente - por meio de participações societárias majoritárias. Nesses casos, não há que se falar em aplicação de

48 ARRIBA FERNÁNDEZ, 2004, p. 93-94.

49 Obviamente, esta classificação só faz sentido nos ordenamentos onde há previsão de tais instrumentos para a formação de grupos, como é o caso de Alemanha, Portugal e Brasil. "[E]sta clasificación solo tiene sentido em aquellos ordenamientos que han acogido uma regulación sistemática de los grupos de sociedades basada en el modelo contractual [...], puesto que, [...] este modelo es de carácter dualista al admitir dos tipos de grupos: los grupos de derecho (los creados conforme a la ley) y los grupos de hecho (el resto de agrupamentos de sociedades en las que confluye una direccíon unitaria)." (Ibid., p. 94).

50 Conforme ANTUNES, 2002, p. 73; ARRIBA FERNÁNDEZ, op. cit., p. 94. 
regras especiais; aplica-se, a estas sociedades, o direito comum das sociedades individualmente consideradas. ${ }^{51-52}$

\subsubsection{Grupos de subordinação e grupos de coordenação}

Neste caso, o critério de classificação é a posição relativa dos sujeitos integrantes do grupo. São grupos de subordinação (também chamados de grupos hierárquicos ou verticais) aqueles em que as sociedades controladas estão em situação hierárquica de dependência em relação à sociedade controladora. Em contrapartida, os grupos de coordenação (também chamados de grupos paritários ou horizontais) são aqueles em que as sociedades grupadas, embora possam estar sujeitas a uma direção unitária, conservam

51 Cf. ANTUNES, 2002, p. 73. Ainda na lição de Antunes: "Ora só os grupos societários que se hajam constituído com base num desses instrumentos específicos se podem qualificar, com propriedade, 'grupos de direito', por isso mesmo que só então é que aquele regime jurídico excepcional entra em acção, designadamente investindo a sociedade-mãe num verdadeiro e legítimo poder de direção perante as sociedades agrupadas: todas as restantes situações de agrupamento intersocietário que tenham a sua origem noutros instrumentos [...] não despoletam a aplicação de tal regime excepcional, ficando, por conseguinte, a disciplina das relações entre as sociedades componentes sob a alçada dos princípios jurídico-societários gerais, o que significa que, em princípio e designadamente, a condução dos negócios sociais das sociedades-filhas não poderá deixar de se fazer de acordo com a respectiva vontade e interesse sociais próprios. Do mesmo modo que o poder de direção da sociedade-mãe, não tendo tido a sua fonte no molde jurídico-organizativo expressamente desenhado pela lei para a respectiva legitimação, constitui um puro poder de facto e não legal, assim também o grupo societário se dirá de facto e não de direito." (Ibid., p. 75-76.). No mesmo sentido, Fuentes Naharro: "Por su parte, los denominados grupos de hecho o fácticos se puden definir como aquéllos en los que el poder de dirección sobre las sociedades filiales existe y se ejerce pero, por no ajustarse al 'modelo de grupo' previsto juridicamente por el legislador, su régimen queda equiparado a las situaciones de simple dependencia societaria [...].” (2007, p. 53).

52 Viviane Muller Prado salienta que esta distinção entre grupos de direito e grupos de fato é adotada em nossa LSA. Os grupos de fato seriam abordados a partir dos critérios de controle e coligação, mantida a autonomia jurídica das sociedades pertencentes ao grupo (o que, em princípio, inviabilizaria o funcionamento de todas as sociedades no interesse do grupo como uma unidade econômica). Para os grupos de direito, a celebração da convenção de grupo tem regras estabelecendo regime específico e diverso daquele aplicável às sociedades isoladas e independentes, permitindo a subordinação dos interesses de uma sociedade ao de outra ou aos interesses do grupo (2006, p. 55-59). No mesmo sentido, Leonardo de Gouvêa Castellões: "Na primeira das hipóteses (dos grupos de direito), portanto, o grupo de sociedades, (...) desde que para a sua constituição preencha determinados requisitos, é legitimado perante a ordem jurídica, havendo a expressa admissibilidade da chamada 'direção econômica unitária', que poderá ignorar, apenas mediante determinadas condições, obviamente, os interesses das sociedades integrantes do grupo, em prol do interesse conjunto que elas constituem. Na segunda das hipóteses (dos grupos de fato), nega-se a validade de uma 'direção econômica unitária', e assim reafirma-se o princípio da total independência e soberania do ente societário, que deve ser conduzido dentro dos parâmetros fornecido pela necessidade de perseguição do próprio e individual interesse social, sujeitando-se às regras e institutos clássicos de direito societário que se destinam justamente a servir ao intento de preservação do interesse.” (2008, p. 102). Vide também MUNHOZ, 2002, p. 118-120. 
independência entre si. ${ }^{53}$

No primeiro caso, a transferência do centro decisório das sociedades controladas

para a sociedade controladora é unilateralmente definida por esta última, por meio dos

mecanismos mais variados, conforme os ordenamentos em que se verifica (mormente os

contratos de subordinação e as participações societárias majoritárias). No segundo caso, a

transferência das competências decisórias a uma instância superior de direção é feita

voluntariamente pelas empresas grupadas, as quais geralmente participam da definição das

políticas gerais do grupo em condições de igualdade. ${ }^{54-55-56}$

53 ANTUNES, 2002, p. 80, acompanhado por FUENTES NAHARRO, 2007, p. 54-56 e ARRIBA FERNÁNDEZ, 2004, p. 97-98. Arriba indica também que os grupos de subordinação são a imensa maioria dos grupos de sociedades existentes na realidade fática, sendo os grupos de coordenação menos comuns. Isso não significa, contudo, que não possam existir figuras híbridas, onde sociedades agrupadas em torno de uma direção unitária coordenada podem, por sua vez, dominar e dirigir unitariamente uma ou mais sociedades dependentes. Fuentes, por sua vez, indica que o primeiro país a adotar esta classificação foi a Alemanha, em consonância com o regime jurídico que sua legislação societária estabeleceu para os grupos de sociedades (do qual tratar-se-á mais adiante). A autora também indica que os grupos paritários, provavelmente por sua escassa relevância prática, receberam pouca atenção dos legisladores. Entretanto, sustenta que o escasso tratamento legal desta figura também se deve à dificuldade de separar o autêntico grupo paritário de outras modalidades de colaboração empresarial relevantes para o direito antitruste, e que por isso a própria natureza de grupo destes arranjos empresariais é questionada por parte da doutrina. É também a opinião de Antunes: "Com efeito, como vem sendo crescentemente posto em destaque pela doutrina nacional e estrangeira, este tipo de contrato - muito justamente porque pressupõe a manutenção da independência das sociedades envolvidas - guarda significativas afinidades teleológicas com a grande família dos instrumentos jurídicos que estão ao serviço da cooperação intersocietária (juntamente com outras figuras, tais como, por exemplo, o contrato de consórcio, o agrupamento complementar de empresas, as chamadas filiais comuns), e não tanto já apenas com aqueles que servem de suporte à concentração e ao domínio entre sociedades: ora, uma tal matriz teleológico-sistemática peculiar, tornando virtualmente impossível a construção do respectivo regime jurídico com base numa transposição acrítica e 'tale quale' das reflexões expendidas a propósito da disciplina legal de grupos assentes em mecanismos de natureza hierárquica, vem naturalmente colocar ainda mais em destaque as consequências nefastas da referida omissão legal e tornar mais árdua a tarefa assim abandonada ao intérprete e ao julgador da integração deste regime.” (2002, p. 913). A discussão é, sem dúvida, interessante. Contudo, não será aprofundada neste trabalho pelo fato de os grupos de coordenação fugirem ao seu escopo.

54 ANTUNES, 2002, p. 80-81.

55 “[...] Um grupo de subordinação se caracteriza, fundamentalmente, pela relação hierárquica de dependência havida entre as sociedades que o integram. Os grupos de coordenação [...], ao contrário, se caracterizam pela situação de paridade que permeia a relação estabelecida entre as sociedades que o constituem." (CASTELLÕES, 2008, p. 96). No mesmo sentido, Suzy Elizabeth Cavalcante Koury: "Nos grupos de coordenação, caracterizados pela unidade de direção entre empresas juridicamente autônomas, as relações estabelecidas entre elas têm índole igualitária, no sentido de igualdade de forças econômicas, de paridade de possibilidade de decisão, sem que isso implique em unidade de controle. [...] Por sua vez, os grupos de subordinação caracterizam-se fundamentalmente pela unidade de controle, ou seja, pela preeminência de uma empresa sobre a outra, com possibilidade de exercício de dominação, de controle da atividade da subordinada." (KOURY, Suzy Elizabeth Cavalcante. A Desconsideração da Personalidade Jurídica (Disregard Doctrine) e os Grupos de Empresas. 2. ed. Rio de Janeiro: Forense, 1998, p. 59).

56 Eduardo Secchi Munhoz salienta que parte da doutrina, por não reconhecer nos grupos de coordenação a dependência econômica, não os classifica como espécie de grupo, mas como mera associação de empresas, que não deve suscitar maior preocupação do direito societário, pois estas estruturas não afetam os fundamentos do modelo clássico de sociedade anônima isolada. Não obstante, Munhoz entende que mesmo nos grupos de coordenação há dependência econômica, ainda que em nível mínimo, pois exige direção unitária para a orientação comum dos negócios das sociedades integrantes do grupo, em prol da consecução do objetivo comum (2002, p. 116-117). 


\subsubsection{Grupos de base societária, contratual e pessoal}

Aqui o critério de classificação é baseado na natureza jurídica e econômica do instrumento utilizado para a constituição e operação do grupo.

São grupos de base societária aqueles em que a criação do grupo é decorrência de uma técnica própria do direito das sociedades. O exemplo clássico é o grupo criado por meio de participações societárias majoritárias, de forma que "directa o indirectamente, la sociedad matriz posee el número suficiente de participaciones en las diversas sociedades del grupo que le permiten ejercer una dirección unitaria"57.

As formas de organização dos grupos de base societária são vastíssimas. Podem ser citados, a título de exemplo, os chamados "grupos de participação radial", nos quais uma sociedade de comando possui participação majoritária em diversas empresas subordinadas, mas estas independentes entre si. Há também os chamados "grupos de participação piramidal", nos quais uma sociedade de comando participa majoritariamente do capital de duas ou mais sociedades, as quais, por sua vez, são titulares da maioria do capital social de outras sociedades, e assim sucessivamente. Em alguns ordenamentos em que se admite a participação recíproca, verifica-se ainda a existência dos chamados "grupos de participação circular", nos quais a sociedade de comando e algumas sociedades controladas cruzam entre si participações intra-societárias. ${ }^{58-59}$

Os grupos de base contratual, como o próprio nome diz, são aqueles em que a unidade de direção econômica das sociedades grupadas é instituída mediante contrato, ou seja, tem característica negocial. Antunes ensina que os principais instrumentos contratuais utilizados para este fim podem ser classificados em duas categorias ${ }^{60}$ : (i) os "contratos de empresa", cuja finalidade é a instituição de uma integração econômica, financeira e/ou administrativa entre as empresas ${ }^{61}$; e (ii) os "contratos do direito comum", que nada mais

\footnotetext{
ARRIBA FERNÁNDEZ, 2004, p. 95.

ANTUNES, 2002, p. 76-77.

59 Vale destacar aqui a importante observação de ANTUNES, no sentido de que caso as participações entre as empresas seja perfeitamente circulares, o ativo das sociedades grupadas pode, no limite, ser totalmente fictício. (Ibid., p. 77).

60 Ibid., p. 77-78.

61 Dentre eles, o autor cita o contrato de subordinação, o contrato de atribuição de lucros, o contrato de comunhão de lucros e o contrato de cessão e exploração de empresa.
} 
são que contratos comuns de natureza civil ou empresarial que, no caso concreto, podem funcionar como instrumentos de domínio ou dependência econômica entre as empresas. ${ }^{62}$

Por fim, os grupos de base pessoal são aqueles em que a unidade da direção econômica fundamenta-se na identidade dos membros que compõem os órgãos da administração das sociedades grupadas. ${ }^{63-64-}$

\subsubsection{Grupos industriais, financeiros e mistos}

Além das tipologias retro mencionadas, os grupos de sociedades podem ser classificados de acordo com os mais variados critérios. Outra classificação comum é aquela que leva em conta a atividade econômica desenvolvida pelas empresas integrantes do grupo. Assim, fala-se, principalmente, em grupos industriais, financeiros e mistos.

Os termos são auto-explicativos. Grupos industriais são aqueles formados por sociedades cujo objeto principal é o desenvolvimento de atividades comerciais e/ou industriais. Grupos financeiros são aqueles que congregam sociedades cujo objeto consista no desenvolvimento de atividades de natureza financeira (bancária, seguradora, mobiliária etc.). Grupos mistos são aqueles que concentram empresas dedicadas tanto a atividades comerciais e industriais quanto a atividades de natureza financeira. ${ }^{65-66}$

62 Exemplos destes contratos: de franquia, de agência, de concessão comercial, de transferência de tecnologia etc.

63 ANTUNES, 2002, p. 78.

64 Ainda com Antunes: “[...] sublinhe-se que os laços sobre os quais repousam os grupos de base pessoal, muito embora se cristalizem usualmente numa identidade total ou parcial dos administradores ou directores das sociedades agrupadas [...], também se poderão alicerçar numa identidade pessoal ou até familiar das respectivas estruturas accionistas [...]. Conquanto os grupos pessoais possuam uma inegável importância prática, a respectiva disciplina jurídica revela-se espinhosa, já porque muitas vezes os administradores de direito são meros 'testas-de-ferro', actuando por conta dos verdadeiros gestores, já porque os laços pessoais (familiares ou outros meramente fácticos) em que assentam são juridicamente irrelevantes ou se combinam rapidamente com outros estratagemas que camuflam a sua origem pessoal [...]" (Ibid., p. 79).

65 ANTUNES, 2002, p. 82-83.

66 Este critério de classificação também é destacado por CASTELLÕES, 2008, p. 95. Vide também os comentários de Koury sobre a classificação dos grupos em industriais, financeiros e pessoais (1998, p. 6062). Arriba Fernández sustenta que a classificação entre grupos industriais e financeiros deve levar em consideração apenas a atividade da sociedade matriz, sendo o objeto das sociedades controladas mero complemento da atividade produtiva da matriz (op. cit., p. 100). 
Traçados em breves linhas os principais critérios de classificação ${ }^{67}$ dos grupos de sociedades, cumpre dar destaque a dois deles. Este trabalho, como já indicado, dará enfoque aos grupos de subordinação e, em especial, aos grupos de fato, pois, como destaca Munhoz, deles decorre a problemática específica dos grupos de sociedade - a diversidade jurídica e a unidade econômica - além de constituem a esmagadora maioria dos grupos existentes. ${ }^{68}$

A análise dos critérios de classificação dos grupos de sociedades descritos acima demonstra, para os grupos de fato, um denominador comum. Estes grupos são caracterizados pela subordinação dos interesses das sociedades controladas aos interesses da sociedade controladora, por meio do exercício, por parte da última, de uma direção unitária sobre as sociedades filiadas, em maior ou menor grau.

Faz-se necessário, portanto, analisar a questão da direção unitária.

\subsubsection{A principal característica dos grupos de sociedades: a direção unitária}

Antunes aponta que o direito das sociedades é, em sua origem, o direito da sociedade individual e independente ${ }^{69}$, opinião compartilhada por Arriba Fernández ${ }^{70}$. Desde os primórdios das sociedades por ações, como visto anteriormente neste trabalho, a sociedade anônima passou a ser entendida como sujeito distinto de seus membros e buscava a satisfação de interesses próprios. Assim, o direito societário foi estruturado de forma a considerar as sociedades anônimas como sujeitos autônomos, com vontade e interesse próprios.

67 Como indicado, esta dissertação não tem a pretensão de analisar todos os critérios existentes de classificação dos grupos de sociedades, pois este trabalho seria virtualmente impossível e de reduzida utilidade prática. Apenas a título de exemplo, Arriba Fernández menciona ainda outros critérios de classificação, tais como grupos de atividade homogênea e atividade heterogênea e grupos centralizados e descentralizados (aqui também os termos são auto-explicativos). (2004, p. 98 et seq..). MUNHOZ, 2002, p. 118.

69 ANTUNES, 2002, p. 106.

70 "En efecto, el Derecho de sociedades es, aún hoy, el derecho de la sociedad individualmente considerada. Es decir, que el objeto de la regulación vigente es una sociedad autónoma, jurídica y economicamente, que determina libremente su voluntad, ajena a cualquier influencia externa, en función de su propio interés social [...].” (ARRIBA FERNÁNDEZ, op. cit., p. 33). 
O desenvolvimento da empresa logo rompeu com o "arquétipo legal da sociedade comercial enquanto sujeito jurídico e econômico autônomo", para usar a expressão de Antunes. ${ }^{71} \mathrm{O}$ crescimento interno da empresa deu lugar ao crescimento externo, mediante, principalmente, a aquisição do controle societário de outras empresas. A grande empresa, anteriormente organizada em uma estrutura monossocietária, deu lugar a estruturas de organização de natureza plurissocietária. ${ }^{72}$

Falar de uma empresa de estrutura plurissociatária significa dizer que a atividade empresarial é desenvolvida por uma pluralidade de sociedades. Em outras palavras, o grupo de sociedades nada mais é que uma forma de estruturação da empresa por meio da utilização de várias sociedades distintas, as quais compõem o grupo. Reproduzindo as observações de Castellões:

[...] para que se possa cogitar um grupo de sociedades, há que se ter presente, obrigatoriamente, mais de uma sociedade; na hipótese, mais de uma sociedade comercial. E mais do que isso: essas sociedades deverão estabelecer entre si uma espécie de relação conjuntiva, que será, com efeito, o pressuposto preliminar para regular o emprego do vocábulo 'grupo' em sua acepção mais elementar, que vem a ser a 'reunião de coisas que formam um todo'. [...] Essa noção de grupo de sociedades conduz, então, à suposição de existência, no mundo fático, de um ente distinto das peças que o constituem, de representação individualizada que, sobre ser diversa da representação destas peças, situa-nas (as peças) em um segundo plano de visão. É indispensável, porém, que estas peças se mantenham individualmente identificáveis, que preservem suas respectivas representatividades, pois, caso contrário, não se poderia falar em grupo na acepção apontada, que supõe, como já referido, a reunião entre peças. ${ }^{73}$

As palavras deste autor exprimem, com clareza, a idéia de grupo de sociedades. São diversas sociedades que, reunidas, compõem um grupo. O grupo de sociedades possui características e finalidades distintas das sociedades que o compõem, mas nem por isso as sociedades grupadas perdem a sua individualidade. De outra forma, não teríamos um grupo

71 ANTUNES, 2002, p. 108.

72 Ibid., p. 108. O surgimento e reconhecimento da empresa plurissociatária foi potencializado com o reconhecimento da possibilidade de uma sociedade ser sócia de outra sociedade, o que nem sempre foi aceito pela doutrina jurídica. Sobre este aspecto, vide ANTUNES, José A. Engrácia. Liability of Corporate Groups. Deventer: Kluwer Law and Taxation, 1994, p. 29-37.

73 CASTELLÕES, 2008, p. 76. 
de sociedades, mas sim uma fusão de sociedades para a criação de um ente distinto. ${ }^{74}$

No item 2, deste capítulo, foram apresentados diversos conceitos de grupos de sociedades no direito comparado. Em que pese os distintos contextos legislativos em que cada um destes conceitos foi elaborado por seus respectivos autores, um elemento comum a todos eles é facilmente identificado: a direção unitária. De fato, a doutrina é de certa forma pacífica em defender que o elemento que confere às distintas sociedades o caráter de grupo é a direção unitária e, por isso, pode-se dizer que a direção unitária é a principal característica dos grupos de sociedades. Esta direção unitária, exercida em todas as

74 A doutrina por vezes questiona conveniência de atribuição de personalidade jurídica aos grupos de sociedade. Na opinião de Comparato e Salomão Filho, o grupo econômico "constitui, em si mesmo, uma sociedade. Os três elementos fundamentais de toda relação societária - a saber, a contribuição individual com esforços ou recursos, a atividade para lograr fins comuns e a participação em lucros e prejuízos encontram-se em todo grupo." Para os autores, ainda que o legislador não reconheça a personalidade jurídica dessa "sociedade de segundo grau", há necessariamente unidade de direção e intercomunicação patrimonial entre as sociedades grupadas. Assim, ainda que não seja reconhecida a personalidade jurídica dos grupos, é mister a sua definição legal suficientemente clara e precisa, para conferir certeza jurídica ao instituto. Ao mesmo tempo, a definição deve ser bastante ampla e aberta de forma a abarcar todas as formas de grupos, mesmo as mais sutis ou menos ortodoxas. Reside aí a grande dificuldade. (COMPARATO; SALOMÃO FILHO, 2008, p. 360). Jorge Lobo sustenta que deveria ser atribuída personalidade jurídica aos grupos de sociedades. Para este autor, "o grupo está para as sociedades grupadas assim como a sociedade isolada está para a pessoa de seus sócios ou acionistas: nesta, como naquele, a pessoa dos membros não se confunde com a instituição resultante das diversas partes; no grupo essas partes são as sociedades grupadas; na sociedade, são os sócios ou acionistas. Uma e outra, tal como seus componentes, possuem personalidade." A atribuição de personalidade jurídica aos grupos, segundo este autor, seria uma forma de garantir a satisfação de créditos de credores externos das sociedades filiadas: "[...] devem ser penhorados bens de qualquer sociedade componente do grupo para garantia da completa liquidação da obrigação assumida e não adimplida, na esteira do princípio pacífico de que, entre as sociedades do grupo, há uma autêntica, completa e inarredável confusão patrimonial, que há de existir não apenas para beneficiar o grupo, mas também, quiçá sobretudo, para garantia dos credores na aplicação da prática da teoria da desconsideração da personalidade jurídica em razão do controle no seio do grupo econômico.” (1997, p. 111-116). José A. Engrácia Antunes, em contrapartida, considera a personalização dos grupos inadequada. Para este autor, a personificação do grupo representaria um contra-senso com a especificidade deste fenômeno, visto que a personalidade jurídica destruiria a pluralidade jurídica que é justamente o seu pressuposto: “[...] reconhecendo personalidade jurídica ao grupo, a lei não estaria a organizar a sua existência mas antes ironicamente a eliminá-la, já que um grupo com personalidade jurídica deixaria de o ser para passar a aproximar-se de uma espécie de fusão operada 'ex lege'." Além disso, a personificação dos grupos seria inconsistente com a prática organizativa desta figura empresarial, que é, em verdade, uma alternativa à empresa unissocietária altamente centralizada. Os grupos de sociedades são um fenômeno multiforme com uma enorme variedade de graus de concentração, e a personalização destas figuras terminaria por "engessar" o instituto. (2002, p. 155-156). A posição de Antunes parece mais acertada. No mesmo sentido, bem aponta Leonardo de Gouvêa Castellões: "O substrato fático de um grupo de sociedades, ao contrário do que ocorre nas empresas unissocietárias relativamente a seus membros, reside precisamente na autonomia jurídica das sociedades que o integram. Em outras palavras: para que um grupo de sociedades tenha razão de ser, é necessário que as sociedades que o compõem realizem negócios jurídicos individualmente, embora sob uma regência superior. [...] [A]s razões de constituição de um grupo de sociedades residem justamente nesta autonomia." (2008, p. 84). Também Embid Irujo: "Como es ben sabido, el grupo es, esencialmente, un agregado de sujetos y no se pretende, mediante esa fórmula de integración empresarial, una personalización específica; en este sentido, se ha dicho acertadamente que en el grupo hay superposición y no refundición de figuras, como sucede en otras modalidades de concentración económica de las que la fusión es, sin duda, el ejemplo más acabado." (EMBID IRUJO, José Miguel. Introducción al Derecho de los Grupos de Sociedades. Granada: Comares, 2003, p. 3). 
sociedades integrantes do grupo, confere-lhes unidade econômica, embora as sociedades pertencentes ao grupo permaneçam juridicamente independentes. Como salienta Munhoz, acompanhado por outros autores, a característica fundamental dos grupos de sociedades é a unidade econômica na diversidade jurídica. ${ }^{75,76}$

Mister, portanto, realizar uma análise detalhada dos principais elementos que caracterizam a direção unitária nos grupos de sociedades.

\subsubsection{A situação de dependência e o conceito de influência dominante}

Para se falar em direção unitária, primeiramente deve-se analisar o conceito de dependência entre sociedades distintas.

Arriba Fernández, baseada na doutrina alemã, define a situação de dependência (ou de domínio) da seguinte maneira: "Una sociedad es dependiente de otra (sociedad dominante) cuando esta última puede ejercer, directa o indirectamente, una influencia

75 MUNHOZ, 2002, p. 261.

76 "Lo característico del grupo consiste, por tanto, em hacer compatible la 'diversidad' inherente al mantenimiento de la personalidad jurídica de las sociedades del grupo com la unidad económica que caracteriza a toda empresa y que se basa en el ejercicio de uma dirección económica común. Se puede hablar, consecuentemente, de que en el grupo, frente a la empresa unitaria, organizada o no bajo forma jurídica de sociedad, nos encontramos ante una empresa articulada, que consigue realizar sus fines mediante la integración de diversas sociedades bajo una dirección económica comum, o dirección unitária. [...] Es, precisamente, la dirección unitaria el elemento característico del grupo de sociedades." (EMBID IRUJO, José Miguel. Grupos de Sociedades y Accionistas Minoritarios. Madrid: Ministerio de Justicia - Centro de Publicaciones, 1984a, p. 153-154). Ainda o autor: "Es, precisamente, la dirección económica única - o la dirección unitária, sugún la terminologia acostumbrada en la doctrina y la legislación - el elemento central y, a la vez, característico del grupo de sociedades." (EMBID IRUJO, José Miguel. Algunas Reflexiones Sobre los Grupos de Sociedades y su Regulación Juridica. RDM, ano XXIII, n. 53, p. 18-40, jan./mar. 1984b, p. 21). No mesmo sentido, Arriba Fernández: "Para que exista un grupo de sociedades es necesario que concurran simultáneamente los seguientes elementos: independencia jurídica de las sociedades miembros y existencia de un poder de dirección unificado (dirección unitaria). [...] La autonomia jurídica de los integrantes del grupo se contrapone a la pérdida de autonomía que esta forma de organización empresarial conlleva. Es lo que la doctrina de medio mundo denomina 'concentración o unidad en la pluralidad' [...]" (2004. p. 87). Para Galgano, é esta "unidade na pluralidade" o maior problema jurídico inerente aos grupos: "La maggiore difficoltà concettuale che si encontra nell'affrontare i problemi giuridici di società sta nel comprendere come l'unità del gruppo si combini con la pluralitá delle società che lo compongono.” (2003, p. 67). No mesmo sentido, tratando dos grupos de fato no direito brasileiro, Pereira Neto indica que a lei brasileira tampouco descuida da "existência, na realidade fática, de um conjunto de sociedades articuladas sob uma direção unitária.” (PEREIRA NETO, Edmur de Andrade Nunes. Anotações sobre os Grupos de Sociedades. RDM, ano XX, n. 82, p. 30-38, abr./jun. 1991, p. 31). 
dominante sobre la primera. Por tanto, la posibilidad de ejercer una influencia dominante es lo que caracteriza la situación de dependéncia."77

Desta forma, a análise do conceito de influência dominante torna-se elemento chave para a compreensão da situação de dependência entre duas ou mais sociedades. "Dicho de otro modo, la dependencia se define por la influencia dominante y las características de ésta son predicábles de aquélla. "78

Para Comparato, a noção de influência dominante é bastante ampla e corresponderia à noção de poder de controle, em sua mais ampla acepção (incluindo todas as modalidades de controle interno - totalitário, majoritário, minoritário e gerencial - além do controle externo ${ }^{79}$ ). Contudo, a expressão seria muito mais alusiva que descritiva, carecendo de precisão. Em vista disso, a idéia de influência dominante seria uma mera diretriz ou indicação para o intérprete na análise dos elementos de fato. ${ }^{80}$

77 ARRIBA FERNÁNDEZ, 2004, p. 107-108. No mesmo sentido, Fuentes Naharro: “La doctrina considera que la noción de dominio es inseparable del concepto de influencia dominante, haste el punto en que se puede afirmar que una sociedad domina a otra unicamente cuando tiene la capacidad necesaria para ejercer una influencia dominante sobre ella.” (2007, p. 97-98). As opiniões das autoras mencionadas acima se baseiam não apenas na doutrina, mas também no próprio direito espanhol. A lei de sociedades anônimas espanhola define a sociedade dominante em seu artigo 87.1 como a sociedade que, por qualquer meio, pode exercer influência dominante sobre a sociedade dominada. Antunes adota posicionamento bastante semelhante (2002, p. 451), com base não apenas no direito comparado, mas também no Código de Sociedades Comerciais português, que determina em seu artigo $486^{\circ}, \mathrm{n}^{\circ}$ 1: "considera-se que duas sociedades estão em relação de domínio quando uma delas, dita dominante, pode exercer, directamente ou por sociedades ou pessoas que preencham os requisitos indicados no art. $483^{\circ}, \mathrm{n}^{\circ} 2$, sobre outra, dita dependente, uma influência dominante".

78 ARRIBA FERNÁNDEZ, op. cit., p. 118.

79 “A influência dominante é presumida, como se viu, quando há participação majoritária de uma empresa em outra. Mas ela pode também exercer-se fora de qualquer participação societária de capital, notadamente pela via contratual." (COMPARATO, Fábio Konder. Grupo Societário Fundado em Controle Contratual e Abuso de Poder do Controlador. In: ___ . Direito Empresarial - estudos e pareceres, São Paulo: Saraiva, 1995b , p. 276). Vide as lições do referido autor sobre as modalidades de controle interno e externo em COMPARATO; SALOMÃO FILHO, 2008, p. 51-103. No mesmo sentido, vide PINTO, Luís Felipe de Carvalho. Grupo de Sociedades e Abuso do Acionista Controlador. RDM, n. 108, p. 171-185, out./dez. 1997, p.183-185.

80 COMPARATO; SALOMÃO FILHO, op. cit., p. 81. 
Esta opinião é compartilhada por Salomão Filho. ${ }^{81}$

Até o momento, de fato, a doutrina parece ter sido incapaz de chegar a um conceito de influência dominante. Em opinião semelhante à dos autores indicados acima, Antunes declara que o conceito de influência dominante é uma noção praticamente desconhecida na tradição legislativa, doutrinal e jurisprudencial. Embora reconhecida na realidade do mundo das sociedades comerciais, a influência dominante seria "insuscetível de ser apreendida num molde conceitual acabado e fechado". 82

Para Guidugli, contudo, apesar das dificuldades da doutrina e do legislador de certos países com relação à construção de um conceito de influência dominante, os esforços podem ser aproveitados, especialmente para o estudo do fenômeno do controle externo (que é mencionado em maior detalhe mais adiante). Em verdade, o conceito de influência dominante diversas vezes se confunde com o conceito de controle.

Para este autor, o grande desconforto dos autores no que diz respeito à influência dominante é a infinidade de situações que o princípio quer compreender, mas isso seria apenas um reflexo das inúmeras situações em que um sujeito pode exercer controle sobre

81 “'A expressão 'influência dominante' ganha em precisão quando aplicada ao direito concorrencial para indicar aquelas situações em que, mesmo sem a existência de controle no sentido societário, há o poder de dirigir a atividade e modificar estruturalmente a sociedade, produzindo efeitos de concentração econômica. É inegável, no entanto, que dadas as dificuldades de aplicar os padrões de direito concorrencial ao direito societário (exatamente por suas diferenças de escopo), a indefinição permanece quando a expressão é utilizada em matéria societária." (COMPARATO; SALOMÃO FILHO, 2008, p. 81). Para estes autores, a diferença de escopo entre o direito societário e o direito concorrencial consiste no seguinte: enquanto o direito societário preocupa-se com a determinação dos rumos sociais por interesses estranhos aos interesses da sociedade (por exemplo, os interesses pessoais do controlador), o direito concorrencial preocupa-se com a manutenção das estruturas de mercado consideradas desejáveis do ponto de vista econômico. Desta forma, o objeto de proteção do direito societário é o interesse dos acionistas minoritários e credores, ao passo que o objeto de proteção do direito concorrencial é a concorrência e os consumidores. Assim, o conceito de influência dominante ganha "concretude" no âmbito do direito concorrencial, pois a preocupação é com os efeitos da dominação societária sobre o mercado, ou seja, a possibilidade de influenciar o comportamento de uma empresa no mercado. No direito societário, em que a preocupação é com atos que possam implicar em disposição patrimonial, o conceito de influência dominante seria "excessivamente abrangente para ter qualquer utilidade aplicativa". (SALOMÃO FILHO, Calixto. Direito Concorrencial - as estruturas. 2. ed. São Paulo: Malheiros, 2002, p. 252-257).

82 ANTUNES, 2002, p. 451-454. O autor, baseado no direito comparado, apresenta diversas tentativas de conceituação da influência dominante, indicando que as propostas de definição são sempre genéricas ou mesmo tautológicas, tais como "a circunstância de uma sociedade dispor de meios para submeter à sua vontade a sociedade dependente", "poder de determinar as atividades de outra sociedade no sentido desejado", "influir de modo determinante nos processos decisórios internos de outra sociedade", "poder soberano de direção e comando sobre outra sociedade" etc. Sobre a dificuldade de se conceituar a influência dominante, vide também PRADO, Viviane Muller. Noção de Grupo de Empresas para o Direito Societário e para o Direito Concorrencial. Revista de Direito Bancário e do Mercado de Capitais, n. 2, p. 140-156, maio/ago. 1998. 
uma sociedade (e o controle, neste contexto, deve ser entendido em sua acepção mais ampla, incluindo as formas de controle interno e externo).

\begin{abstract}
[A]ntes de um fracasso, as posturas e esforços dos diferentes legisladores e doutrinadores levaram ao reconhecimento que a influência dominante não é docilmente tipificada em um elenco taxativo, tenha ele a extensão que for. [...] Os autores que se concentraram no estudo sobre as noções de influência dominante, mesmo que tenham fracassado, até o momento, em oferecer uma lista completa e precisa de suas manifestações (se é que tal lista um dia surgirá) criam ou, ao menos, sugeriram as ferramentas necessárias para a investigação das manifestações do controle, não importando onde estiver localizado. ${ }^{83}$
\end{abstract}

Em vista disso, a doutrina tem concentrado seus esforços não exatamente no conceito de influência dominante, mas sim na identificação das características que lhe são próprias, os institutos jurídicos em que se baseiam e os seus principais elementos ${ }^{84}$, aspectos estes tratados a seguir.

Um dos elementos apontados pela doutrina como caracterizador da influência dominante é a potencialidade. Significa dizer que a situação de dependência entre duas ou mais sociedades está caracterizada quando uma delas, a sociedade dominante, tem a mera possibilidade de exercer a influência dominante sobre as demais, independente do fato de tal influência dominante ser efetivamente exercida. ${ }^{85}$

Cumpre esclarecer que a situação de dependência e o exercício da influência dominante por uma sociedade sobre outra não é, per se, prejudicial à sociedade dominada. Tendo a influência dominante um caráter de potencialidade, ela pode simplesmente não ser exercida ou, se exercida, pode não representar qualquer desvio, para a sociedade dominada, na consecução do seu objeto social. Neste caso, a influência dominante não possui relevância jurídica. Somente quando a influência dominante for exercida em prejuízo da

83 GUIDUGLI, João Henrique. Controle Externo Contratual. São Paulo: Quartier Latin, 2006, p. 66-67.

84 ANTUNES, 2002, p. 454. No mesmo sentido, Arriba Fernández: "[D]ebemos puntualizar que el concepto de influencia dominante es de difícil aprehensión, incluso para el legislador que se circunscribe a delimitarlo a través de los mecanismos o instrumento que le dan origen y, en última instancia, mediante el empleo de presunciones." (2004, p. 118).

85 Conforme ARRIBA FERNÁNDEZ, op. cit., p. 118-119; ANTUNES, op. cit, p. 454-455. 
sociedade dominada (como acontece na maioria das vezes), a análise do seu exercício torna-se relevante para o Direito. ${ }^{86}$

Além disso, a influência dominante deve ser estável, ou seja, seu exercício deve basear-se unicamente na vontade de seu titular, sem interferência de quaisquer terceiros. Admite-se, por exemplo, que a influência dominante possa ser duradoura apenas por um determinado período de tempo, mas, enquanto persistir, não pode ser casual ou fortuita. ${ }^{87}$

Outra discussão presente na doutrina é o alcance (ou amplitude) da influência dominante, i.e., quais são os setores da atividade empresarial em que uma sociedade deve exercer influência para que esta seja qualificada como "dominante".

Arriba Fernández e Antunes indicam que a discussão que existe na doutrina, com relação a este aspecto, reside na dúvida se a influência deva ser exercida sobre todas as atividades da sociedade controlada para ser considerada dominante ou se, para tanto, basta ser exercida sobre apenas alguns setores estratégicos da sociedade controlada.

Para o autor português, embora a doutrina majoritária alemã sustente que a influência dominante juridicamente relevante deva revestir-se de caráter geral (i.e., recair sobre todas as áreas de atuação da sociedade dominada), a solução mais adequada parece ser a de que pode existir influência dominante com influência da sociedade dominante em

86 ARRIBA FERNÁNDEZ, 2004, p. 108.

87 Ibid., p. 119-121. A lição de Antunes é bastante clara: "Pense no caso das chamadas maiorias ocasionais das assembléias gerais, tornadas possíveis em virtude dos conhecidos fenómenos de dispersão do capital e do abstencionismo accionista no seio das grandes sociedades anónimas, especialmente das cotas em bolsa. Suponha-se assim, por exemplo, que a sociedade A detém uma participação de $20 \%$ no capital da sociedade B e que, em reunião, da Assembléia Geral desta última, a sociedade A, em consequiência da reduzida taxa de afluência dos accionistas ou em virtude de uma inesperada adesão de numerosos accionistas individuais, consegue obter uma maioria de votos na assembléia de B e, deste modo, consegue fazer aprovar deliberações sociais nos sentido desejado. 'Quid juris'? Parece que a influência dominante relevante não poderá deixar de ser apenas aquela que exprima um domínio institucionalizado (estável), sendo irrelevante o domínio puramente fortuito (instável). [...] Significa isto que haverá que distinguir claramente entre os casos em que ]al influência reflecte uma situação de domínio estrutural - isto é, resultante da detenção de instrumentos jurídicos-institucionais de controlo que garantem a uma sociedade a possibilidade de influir de forma estável e permanente na condução dos negócios sociais de outra (designadamente, um poder majoritário de designação e destituição dos membros dos órgãos de administração da sociedade dependente, que lhe assegure assim a possibilidade de impor mediatamente o cunho da sua vontade na gestão social desta) - e aqueles outros em que a situação de domínio resulta da circunstâncias absolutamente conjunturais ou causais [...]" (2002, p. 455-456). Com relação a possibilidade de existência de lapso temporal para exercício da influência dominante, Ibid., p. 459-460). A opinião é compartilhada por Mónica Fuentes Naharro: "Además, tal domínio se considerará efectivo unicamente em tanto la sociedad dominante tenga um poder estable y determinante sobre la actividad del sujeto dominado." (2007, p. 98). 
apenas alguns setores fundamentais da controlada. Esta posição parece mais acertada e é compartilhada por Arriba Fernández. ${ }^{88}$

A autora espanhola apresenta valioso exemplo:

[S] la capacidad de influir se despliega sobre el sector financiero o sobre la política de personal, entendiendo por tal la elección de los miembros del órgano de administración, no puede dudarse de la existencia de una influencia dominante. Una sociedad que no pueda disponer libremente de sus recursos financieros no es una sociedad independiente, porque no podrá ejecutar de acuerdo a sus designios la política empresarial que haya diseñado, aun sin coacciones. [...] En cuanto a la política de personal, quien tenga atribuida la facultad de designar a todos o a la mayoría de los miembros del órgano de administración, tendrá la capacidad para ingerirse en la gestión de la sociedad en cuestión. De suerte que tendrá la posibilidad de influir en el día a día de la sociedad y con respecto a cualquier sector empresarial. ${ }^{, 89}$

Antunes complementa o raciocínio sustentando que dada a interdependência existente entre as várias funções empresariais (produção, vendas, finanças, pessoal etc.), o domínio de um destes setores acabará repercutindo sobre toda a atividade econômica da sociedade, de forma que uma influência setorial pode redundar, ao final, em uma influência de caráter geral. ${ }^{90-91}$

\subsubsection{Instrumentos (ou mecanismos) geradores da influência dominante}

Feitas as considerações anteriores sobre os principais elementos que caracterizam a influência dominante, passa-se à análise dos instrumentos ou mecanismos mais relevantes que possibilitam a sociedade de comando exercer influência dominante sobre a sociedade dominada.

\footnotetext{
Vide ANTUNES, 2002, p. 464-469 e ARRIBA FERNÁNDEZ, 2004, p. 121-122.

ARRIBA FERNÁNDEZ, op. cit., p. 121-122.

ANTUNES, op. cit., p. 468.

91 Sobre as considerações acima a respeito dos elementos que caracterizam a influência dominante (do ponto de vista societário), vide, no mesmo sentido, a síntese de OLIVEIRA JÚNIOR, Antônio Sydney de. O Contrato Como Poder de Influência Dominante e as Conseqüências do seu Uso Abusivo. São Paulo: Método, 2004, p. 47-59.
} 
O principal deles (especialmente considerando os grupos fáticos de subordinação, objeto deste trabalho) é a detenção de participação no capital social da empresa dominada.

Se a sociedade dominante é detentora de participação totalitária no capital social da sociedade dominada, parece óbvio que a primeira controlará a vida e a gestão social da dominada (determinando os rumos das deliberações nas assembléias gerais e indicando todos os membros da administração da sociedade dominada), evidenciando aí a existência da influência dominante.

No caso de participação majoritária no capital social da sociedade dominada, a influência dominante também é facilmente percebida, mas comporta algumas qualificações. Se uma sociedade detém a maioria do capital social de uma sociedade, seguindo o princípio básico de "uma ação um voto", terá o poder de "impor o cunho de sua vontade, imediatamente, nas deliberações da Assembléia Geral da sociedade participada, e, mediatamente (através do direito de designação, remuneração e destituição dos administradores, directores, ou gerentes), na conformação do sentido geral da respectiva gestão social." 92

A propriedade de maioria do capital social de uma sociedade implica geralmente, mas não necessariamente, em existência de influência dominante, na medida em que “existen supuestos en los que la mayoría del capital no da lugar a la mayoría de los derechos de voto [... ${ }^{, 93}$. Um acionista pode deter a maioria do capital social de uma empresa, mas esta maioria do capital pode ser constituída por ações sem direito a voto (conforme art. 111 da LSA). Além disso, há inúmeros outros casos previstos na legislação que excetuam a regra "uma ação, um voto", sem prejuízo de outras exceções que possam ser previstas nos estatutos sociais das sociedades envolvidas. ${ }^{94}$

\footnotetext{
ANTUNES, 2002, p. 487-488.

ARRIBA FERNÁNDEZ, 2004, p. 123. No mesmo sentido: “La participación societaria (mayoritaria) parece ser el principal vínculo de dominio orgánico por excelencia entre sociedades. Sin embargo, esta afirmación requiere una matización: [...] em la práctica, la mayoría de las partes sociales no asegura la creación de una relación de dominio-dependencia, sino la tenencia de la mayoría de los derechos de voto." (FUENTES NAHARRO, 2007, p. 101). Esta autora indica que isto é verdade também no direito alemão, onde o $§ 17.2$ da lei societária determina que uma sociedade com controle majoritário presume-se em situação de dependência da sociedade que ostenta a sua participação majoritária.

94 Exemplo dos casos previstos na legislação brasileira: exclusão de direito de voto em casos de conflitos de interesse (art. 115, LSA), suspensão de direito de voto das ações do capital da controladora detidas pela controlada (art. 244, $\S 2^{\circ}$, LSA), além de, conforme as circunstâncias, a opção pelo voto múltiplo previsto no art. 141 da LSA. Restrições estatutárias poderiam ser, por exemplo, aquelas realizadas nos termos do art. $110, \S \S 1^{\circ}$ e $2^{\circ}$ da LSA.
} 
Com base no anteriormente exposto, pode-se afirmar que a detenção de maioria dos direitos de voto na sociedade participada é instrumento idôneo para que exista influência dominante da controladora na controlada. ${ }^{95-96}$

Outro mecanismo apto a criar situação de dependência entre duas sociedades (ensejando o exercício de influência dominante pela sociedade controladora) é a existência de interdependências pessoais. Na boa definição de Fuentes Naharro:

La coincidencia de administradores comunes en los órganos de administración de diversas sociedades es un mecanismo del que puede surgir una relación de dependéncia o de grupo. Estas vinculaciones personales entre dos o más sociedades tienen lugar cuando la composición mayoritaria del órgano de administración de una sociedad (que pasará a ser dependiente), se cubre con miembros del órgano de administración o con altos directivos de otra sociedad (a la postre, dominante) o de una sociedad por ésta dominada. ${ }^{97}$

No direito anglo-saxão, a existência de administradores comuns entre sociedades distintas é denominada interlocking directorates. Esta prática, segundo a doutrina, é capaz não apenas de gerar situação de dependência entre sociedades, mas também problemas inerentes à proteção da concorrência, na medida em que pode haver administradores comuns entre empresas competidoras.

The interlocking directorates resulting from this practice create a complex pattern of connections between nominally independent firms. The Federal Trade Commission found that one out of eight interlocks among very large firms connected potential competitors, and Vance reports that if indirect interlocks (in which two representatives of different corporations sit on the board of a third

95 Parágrafos anteriores conforme ARRIBA FERNÁNDEZ, 2004, p. 123-135; ANTUNES, 2002, p. 483497.

96 Ressaltem-se as observações de Antunes e Arriba com relação ao controle minoritário. Para o autor português, a titularidade de frações do capital social inferiores à maioria poderá dar margem ao surgimento de influência dominante sempre que tal participação, aliada a "determinados circunstancialismos específicos de natureza vária (tais como acordos de voto, cláusulas estatutárias especiais, dispersão do capital e etc.) que concorram no caso concreto, permita à sociedade sóciaminoritária impor o cunho de sua vontade na conformação do governo corporativo e da gestão social da sociedade participada." (op. cit., p. 498 et seq.). Para a autora espanhola, de forma semelhante, somente a combinação de uma minoria de direitos de voto com outro mecanismo de domínio fará surgir a possibilidade de influir em outra sociedade (um acordo de votos ou identidade dos membros da administração e dos membros que compõem a minoria por exemplo). Em qualquer caso, essa combinação não pode ser fortuita, ou a possibilidade de exercício da influência dominante não estaria assegurada (op. cit., p. 135-136).

97 FUENTES NAHARRO, 2007, p. 103. 
firm and thus have face-to-face interaction on a regular basis) are counted, about 80 percent of all firms are interconnected with at least one competitor and innumerable potential suppliers and consumers. Such a situation may indicate collusion between ostensively competitive companies or control of some firms by others, since control based on financial power can be most easily maintained by placing representatives on the board of a captive firm. ${ }^{98}$

Arriba Fernández sustenta que não é qualquer coincidência na identidade dos administradores da sociedade controlada e da controladora que enseja o surgimento de uma relação de dependência. Para a autora, é necessário que a maioria dos administradores da sociedade dominada seja coincidente com os da dominante, ou a interdependência pessoal não seria juridicamente relevante. ${ }^{99}$ Antunes, complementando esta idéia, diz que a identidade ou comunidade dos membros da administração da sociedade controlada e da controladora não constitui, de per si, uma relação de domínio intersocietário, devendo as situações, no caso concreto, serem analisadas. Além disso, o autor destaca que a viabilidade prática deste mecanismo para o surgimento de relação de dependência esbarra em certas restrições legais em matéria de incompatibilidades dos titulares de órgãos de administração. $^{100}$

Não obstante as exceções descritas acima, não há dúvida que as interdependências pessoais são mecanismos hábeis a criar situação de dependência entre sociedades.

Disposições estatutárias também são mecanismos aptos a ensejar situação de dependência entre sociedades sempre que tais disposições atribuam a um ou determinados sócios determinados privilégios que facilitem o exercício da influência dominante. Exemplos destes casos são previsões estatutárias de voto plural $^{101}$, ações que conferem

98 KOENIG, Thomas; GOGEL, Robert; SONQUIST, John. Models of the Significance of Interlocking Corporate Directorates. American Journal of Economics and Sociology, v. 38, n. 2, p. 173-186, Apr. 1979, pp. 173.

99 ARRIBA FERNÁNDEZ, 2004, p. 139-149.

100 No direito português, por exemplo, há proibição de membros do conselho de administração de uma sociedade exercerem cargos não estatutários nas sociedades que com aquela se encontre em relação de grupo ou domínio; proibição de designação ou eleição como membro do conselho fiscal, como fiscal único ou como revisor oficial de contas de uma sociedade, dos membros dos órgãos da administração ou dos prestadores de serviço de sociedade que com ela esteja em relação de grupo ou domínio; proibição de designação como membro de direção de uma sociedade de membro do órgão de fiscalização de sociedade que com aquela esteja em relação de grupo ou domínio; e proibição dos gerentes, administradores, ou diretores exercerem, sem consentimento dos sócios, atividade concorrente com a da sociedade, ou de celebrarem contratos em relação de domínio ou de grupo, entre outros exemplos (ANTUNES, 2002, p. 534-536). Com relação ao último exemplo mencionado, o direito brasileiro possui restrição semelhante de maneira implícita, quando trata do deveres dos administradores para com a companhia (art. 153 e SS, LSA). Com relação aos demais exemplos mencionados, não há disposição semelhante na LSA.

101 Como é o caso do já mencionado voto múltiplo, previsto no art. 141 da LSA. 
direito à eleição em separado de um ou mais membros do conselho de administração ${ }^{102}$, ou ações que conferem direito de veto em determinadas matérias deliberadas pela assembléia geral. ${ }^{103-104}$

Antunes destaca que, em princípio, estes mecanismos dificilmente geram, por si só, uma situação de dependência, sendo na verdade instrumentos que reforçam ou consolidam uma influência dominante já existente. Estes mecanismos poderiam, quando muito, dar origem a uma situação de dependência se combinados com outros instrumentos, especialmente as participações de capital. ${ }^{105}$ Não obstante, Arriba Fernández destaca outra possibilidade, que é a "constitución ex novo de sociedades que nacen ya con la vocación de ser sociedades dependientes". Neste caso, o próprio estatuto social destas sociedades traria disposições no sentido de favorecer a cooperação entre as sociedades vinculadas. Para a autora, estas sociedades teriam a particularidade de "nascerem dependentes" e ter a proteção de seus sócios e credores minimizada, na medida em que sua condição de dominada foi aprovada na assembléia de constituição e está sedimentada em seus estatutos. $^{106}$

Por fim, contratos são instrumentos igualmente capazes de gerar relação de dependência entre sociedades.

Alguns ordenamentos, tais como o alemão e em certa medida o português e o italiano, prevêem a figura dos chamados contratos de integração empresarial ou contratos de empresa.

Estes contratos são aptos a criar e manter o domínio intersocietário entre duas ou mais empresas e, segundo nos ensina Comparato, no direito alemão são os únicos aptos a constituir um grupo econômico de direito, na medida em que operam alterações nos fins sociais das sociedades que assinam, passando estas a atuar em função do interesse geral do grupo (e por isso tais contratos devem ser levados ao registro do comércio para que

102 Como é o caso do art. 16, III da LSA.

103 Como é o caso das golden shares previstas no art. 17, § $7^{\circ}$ da LSA.

104 Conforme ARRIBA FERNÁNDEZ, 2004, p. 142-144; ANTUNES, 2002, p. 517-521; FUENTES NAHARRO, 2007, p. 103-104.

105 ANTUNES, op. cit., p. 521.

106 ARRIBA FERNÁNDEZ, op. cit., p. 144 
possuam efeitos jurídicos). ${ }^{107}$

Comparato - com o já mencionado Munhoz no mesmo sentido - indica que, no direito alemão, estes contratos consistem no contrato de dominação (ou subordinação), no contrato de transferência de lucros, no contrato de comunhão de lucros, no contrato de transferência parcial de lucros, e no contrato de arrendamento ou cessão de estabelecimento. ${ }^{108}$

O contrato de subordinação (ou dominação), segundo Antunes, está previsto nos $\S \S$ 292 e seguintes da lei societária alemã, no artigo 2359, comma 3 do Código Civil italiano e no artigo 493 do Código de Sociedades Comerciais português. Segundo este autor, trata-se

[...] não de um mero contrato obrigacional ou comutativo, mas de um verdadeiro 'contrato de organização', que vem institucionalizar um poder de direcção de uma sociedade sobre outra sociedade, traduzido essencialmente na submissão legítima da vontade e do interesse sociais próprios desta à vontade e interesses sociais daquela [...]. ${ }^{109}$

Isto institui automaticamente uma relação de domínio entre as sociedades que firmarem o referido contrato. ${ }^{110}$

Os demais contratos de empresa, descritos anteriormente (cujos termos são autoexplicativos), com exceção da Alemanha, são geralmente contratos atípicos. Não obstante sejam bastante usados na prática empresarial e, de fato, sejam instrumentos aptos a criar uma relação de domínio entre as sociedades que dele fazem parte, Antunes indica que a validade jurídica de tais arranjos societários é bastante controvertida no direito comparado.

Todavia, no contexto de ordens jurídicas onde - como acontece na esmagadora maioria das legislações juriscomerciais européias, incluindo a portuguesa - tais contratos não foram objecto de qualquer regulamentação legal, o problema da sua licitude e validade não se pode deixar de colocar, uma vez que tais convenções, interferindo em maior ou menor grau na autonomia patrimonial e

107 COMPARATO; SALOMÃO FILHO, 2008, p. 407.

${ }^{108}$ COMPARATO; SALOMÃO FILHO, 2008, p. 407; MUNHOZ, 2002, p. 274. No mesmo sentido, vide também SEMON, Juan M. Nuevo Derecho Accionario y de "Konzern" de Alemania - Ley de 1965. Buenos Aires: Cangallo, 1969, p. 57-58.

109 ANTUNES, 2002, p. 508-509.

${ }^{110}$ Ibid., loc. cit. 
organizativa dos entes societários envolvidos, são susceptíveis de desrespeitarem alguns dos princípios imperativos básicos do direito comum das sociedades comerciais. [...] [A] té que ponto o acordo contratual escrutinado estará ainda em linha com a máxima segundo a qual os negócios da sociedade deverão ser geridos diligentemente pelos respectivos administradores, directores ou gerentes tendo em vista os interesses da própria sociedade e de seus sócios [...], não visando camuflar, em particular, um contrato de subordinação 'de facto', pelo qual uma sociedade procura assegurar o exercício de um poder de direcção sobre a gestão de outra sociedade contratante sem ter de suportar as responsabilidades e encargos que a lei lhe faz associar?" 111

\subsubsection{Influência dominante resultante de dependência econômica}

Até este momento, os mecanismos geradores de situação de dependência analisados acima possuem natureza jurídica (embora Antunes indique que no caso de interdependências pessoais trata-se de uma relação fática de domínio de natureza pessoal $^{112}$; não obstante a opinião do autor, poder-se-ia dizer que as interdependências pessoais não deixam de ser um instrumento jurídico de geração de situação de dependência na medida em que se originam na estrutura interna das sociedades).

Além disso, pode-se dizer que os instrumentos descritos acima como geradores de situação de dependência possuem um caráter predominantemente societário, mesmo quando se fala nos contratos de empresa - uma vez que, embora atípicos na maioria dos ordenamentos estrangeiros, são inspirados no modelo legal previsto na legislação societária alemã.

Contudo, o exercício da influência dominante pode resultar de situações meramente fáticas de dependência econômica e geralmente decorrentes da celebração de contratos do direito comum, civil e comercial. ${ }^{113}$

111 ANTUNES, 2002, p. 510-516.

112 Ibid., p. 523-524.

113 Note-se que não se afirma, neste item, que não existe dependência econômica entre sociedades sujeitas à influência dominante exercida por um dos mecanismos de caráter societário descritos acima. Ao contrário, como bem sustenta Embid Irujo, "[...] conviene advertir que el sometimiento de las sociedades del grupo a la dirección económica es el resultado, habitualmente, de la existencia de relaciones de dependencia económica entre las sociedades de grupo grácias e las cuales la sociedad que controla las demás - denominada, por ello, sociedad dominante - puede exercer efectivamente la dirección del grupo.” (1984b, p. 21). O que se pretende neste item é distinguir as relações nas quais existe dependência econômica entre as sociedades e a influência dominante, dela decorrente, é exercida por mecanismos 
Estes contratos, embora não constituam um contrato de empresa com a acepção stricto sensu descrita acima, são capazes de criar relações de domínio entre sociedades na medida em que possam constituir uma fonte de dependência econômica entre tais sociedades, tais como contratos de distribuição exclusiva, de agência, de franchising, de licença de patente e know-how etc. ${ }^{114}$

Segundo Forgioni, a dependência econômica caracteriza-se quando um contratante em situação de superioridade em relação à contraparte tem, justamente em decorrência desta superioridade, a possibilidade de impor condições contratuais à outra parte, o qual deverá aceitá-las para sobreviver. ${ }^{115,116}$

Comparato analisa as situações em que a influência dominante resulta da celebração de contratos do direito comum quando trata da figura do controle externo ${ }^{117}$. Os

puramente societários (como as participações de capital, fundamentais no caso dos grupos de fato por subordinação, objeto deste estudo) e as situações onde outros mecanismos não societários são igualmente capazes de desencadear o exercício de influência dominante decorrente de dependência econômica de uma das partes com relação à outra.

114 ANTUNES, 2002, p. 517.

115 FORGIONI, Paula A. O Contrato de Distribuição. São Paulo: RT, 2005, p. 347. Um esclarecimento fazse necessário aqui. Como destaca Forgioni, a dependência econômica não se confunde com o conceito de posição dominante do direito antitruste. O agente detentor de posição dominante é aquele que, em decorrência da detenção de poder econômico, age com independência e liberdade em relação aos concorrentes, aos agentes econômicos atuantes em outros mercados e em relação aos consumidores. $\mathrm{Na}$ dependência econômica, o agente dominante age com liberdade e independência em relação apenas à sua contraparte, não em relação ao mercado. (Conforme FORGIONI, 2005, p. 347-348; Id. Os Fundamentos do Antitruste, São Paulo: RT, 1998, p. 267-271).

116 Sobre os contratos do direito comum capazes de gerar dependência econômica, um breve esclarecimento. Forgioni indica que contratos possuem uma função econômica, e que por isso só são celebrados quando as partes acreditam que a situação resultante do contrato lhes será vantajosa. Caso contrário, a contratação simplesmente não aconteceria. Isso não significa que a contratação estabelecida entre as partes não possa gerar uma situação de dependência econômica entre as partes contratantes. O problema existe quando há abuso desta situação: “[...] há empresários que desfrutam de situação econômica vantajosa em relação ao outro e são capazes de impor sua vontade, dominando o jogo da contratação e utilizando-o a seu exclusivo favor. Esta é, indubitavelmente, uma realidade que tem preocupado os operadores do direito comercial [...]" (FORGIONI, 2003, p. 10). Contudo, pode haver contratos nos quais, apesar da existência de dependência econômica entre as partes contratantes, não há abuso da parte dominante e a cooperação entre as partes pode, de fato, servir a ambas as partes. Como indica Grassi, "num ambiente de acirramento da concorrência e globalização dos mercados, juntar esforços pode ser uma estratégia fundamental na busca de competitividade" (GRASSI, Robson Antonio. Williamson e 'Formas Híbridas': uma proposta de redefinição do debate. Economia e Sociedade, Campinas, v. 12, n. 1, p. 43-64, jan./jun. 2003, p. 43). Sobre as eficiências destes contratos de cooperação entre empresas, vide o já citado artigo de Grassi, além de WILLIAMSON, Oliver E. The Mechanisms of Governance, New York: Oxford University, 1996, p. 93-106; FARINA, Elizabeth Maria M. Q.; AZEVEDO, Paulo Furquim de; SAES, Maria Sylvia Macchione. Competitividade: Mercado, Estado e Organizações, São Paulo: Singular, 1997, p. 71-111; PINHEIRO; SADDI, 2006, p. 60-71.

117 Que ocorre quando o controlador de uma sociedade não é necessariamente membro de qualquer órgão social, mas exerce seu poder de dominação $a b$ extra (conforme COMPARATO; SALOMÃO FILHO, 2008, p. 89). No mesmo sentido, GUIDUGLI, 2006, p. 54: “[...] o controle que se manifestaria à margem dos direitos de sócio, ou seja, trata-se da possibilidade de se conduzir as atividades sociais e, por 
exemplos citados por este autor são vastíssimos: (i) aquele decorrente de endividamento da sociedade, onde o credor passa a dominar a devedora em decorrência de mecanismos diversos (ameaça de falência, garantia sobre as ações, emissão de debêntures etc.); (ii) a situação de dependência instalada nos contratos de franchising e concessão de venda com exclusividade; (iii) a supremacia tecnológica que um fornecedor sobre um distribuidor etc. ${ }^{118}$ Destaque, também, para o caso dos contratos de distribuição, como mencionado por Forgioni em sua tese de livre-docência. ${ }^{119}$

Embora as situações fáticas descritas acima seja, sem dúvida, capazes de criar situação de dependência econômica entre sociedades, a doutrina de maneira geral não considera que tais contratos sejam capazes de criar situações de grupo. ${ }^{120}$ A breve análise que se fez nas linhas antecedentes serve para auxiliar na compreensão do conceito de influência dominante e seus reflexos na direção unitária, esta sim característica dos grupos de sociedade. Especialmente considerando que o foco desta dissertação são os grupos de fato por subordinação, a origem da influência dominante - e, por conseqüência, da direção

conseqüência, de se controlar a sociedade, sem o instrumento do voto ou da participação em qualquer de seus órgãos."

118 COMPARATO; SALOMÃO FILHO, 2008, p. 90-98.

119 "No prisma do relacionamento entre as partes, talvez a nossa maior contribuição seja a investigação da dependência econômica para explicar a realidade enfrentada pelos empresários brasileiros. [...] Embora a doutrina brasileira deduza que no contrato de distribuição há freqüentemente uma forte sujeição entre uma parte à outra, essa dependência nunca foi estudada entre nós de forma sistemática.” (FORGIONI, 2005, p. 39).

120 Vale transcrever a opinião de Mónica Fuentes Naharro: "Lo cierto es que cuando se habla de relaciones de dominio-dependencia entre sociedades, la doctrina parece referirse siempre a la participación financiera de unas sociedades en otras; sin embargo, el dominio no se manifesta siempre de la misma forma. Es preciso distinguir entre el dominio orgánico o jurídico y el domínio económico sobre una sociedad (también calificados como dompinio 'interno' y 'externo' respectivamente), en tanto en cuanto ambos tienen unos efectos jurídicos totalmente diferenciados. En aquel caso, el poder es ejercido valiéndose de los órganos de la sociedad dependiente, y en éste, el poder deriva de las relaciones bilaterales entre sujetos de derecho independientes sin que los órganos de la sociedad, como tales, hayan comprometido la autonomía de su funcionamento. Así, bajo el dominio jurídico los órganos de la sociedad dependiente no pueden ofrecer 'resistencia' u oposición a tal dominio porque son ellos mismos los que están insertos en la mecánica de su ejercicio. La dominación jurídica u orgánica es la que resulta de intervenir en el proceso de formación de la voluntad de la sociedad dependiente, ya sea por medio de una participación social mayoritaria, por medio de contratos que establezcan esta relación de forma específica, a través de disposiciones estatutárias, o a través de vínculos personales entre los distintos órganos de administración de las sociedades que componem el grupo. En cambio, bajo el domínio económico o 'externo' los órganos de la sociedad dependiente no ven sometida la mecánica de la formación de la voluntad social a ningún sujeto dominante. La importáncia de esta distinción subyace en que la doctrina mayoritaria considera que el dominio económico no es susceptible de generar una relación de grupo. De hecho, el ordenamiento alemán, por ejemplo, lo tiene excluido del derecho de grupos, limitándose a regular las relaciones empresariales de dependencia que están basadas en un dominio estrictamente orgánico. Como viene siendo la tónica general, también en España la doctrina mayoritária afirma con rotundidad qe el dominio debe tener siempre un carácter orgánico y que, por lo tanto, debe crearse mediante alguno de los mecanismos que repercuten en la estructura interna de la sociedad, especialmente, en su gestión y toma de acuerdos.” (2007, p. 100-101). 
unitária - será interna. Devido a isso, não serão analisadas em maior profundidade as origens "não societárias" e/ou externas do controle ou da influência dominante.

\subsubsection{Conseqüências jurídicas do exercício da influência dominante}

A situação de dependência caracteriza-se, como visto acima, pela possibilidade de exercício de influência dominante de uma sociedade sobre outra, situação na qual a sociedade titular da influência dominante muito possivelmente exercerá esta faculdade no sentido de intervir ${ }^{121}$ na atuação da sociedade dependente. ${ }^{122}$

A interferência na atuação da sociedade dominada será feita, na maioria dos casos, em consonância com o interesse social da sociedade dominante. Desta forma, quando a sociedade dominante faz uso da sua capacidade de influir na sociedade dominada, os resultados para a dominada podem ser de três tipos diferentes: benéficos, neutros ou prejudiciais.

A ingerência externa é positiva quando gera algum tipo de proveito ou benefício para a sociedade dominada. Podem ser citados os seguintes exemplos desta situação: transferência esporádica de benefícios gerados pela sociedade dominante à sociedade

${ }^{121}$ Com relação a esta "interferência", embora a influência dominante e a possibilidade de intervir na atividade da sociedade dependente sejam, de certa forma, duas facetas do mesmo fenômeno, María Luisa de Arriba Fernández esclarece que a possibilidade de exercício da influência dominante tem origem interna, ao passo que a interferência tem origem externa. O exercício da influência dominante será decorrente de mecanismos internos (leia-se intra-societários) que afetam a organização da sociedade dependente (dentre os que foram tratados acima como, por exemplo, a maioria dos direitos de voto, cláusulas estatutárias, interdependências pessoais etc.). A possibilidade de influir na atividade da sociedade dependente tem origem externa à sociedade dependente, na medida em que se materializar em ordens, deliberações ou recomendações impostas aos administradores da sociedade dependente (ou que tenham como destino os administradores da sociedade dependente), mas que serão originadas no seio da administração da sociedade dominante, ou seja, não há observância do curso habitual de tomada de decisão de uma sociedade, tendo como base as regras do direito societário clássico, aplicável às sociedades individualmente consideradas (2004, p. 153-154).

122 Antes de prosseguir, é necessário um esclarecimento. A capacidade de exercer influência dominante sobre uma sociedade é potencial e, quando utilizada, deve ser de certa forma esporádica. Isso porque, como ensina Arriba Fernández, "la injerencia de la sociedad dominante en la sociedad dependiente deberá reunir una serie de requisitos que la diferencien de la dirección unitaria, es decir, que la injerencia fruto de la situación de dependencia no debe ser idéntica a la injerencia fruto de una relación de grupo. [...] [M]ientras que la intervención ajena fruto de la dependencia debe ser ocasional, la injerencia fruto de la dirección unitaria, del grupo en definitiva, revestirá un carácter más constante.” (Ibid., p. 151). Este esclarecimento é necessário, pois a compreensão do conceito de influência dominante será necessário posteriormente para a análise do conceito de direção unitária. 
dependente (como melhores taxas de juros em financiamentos bancários dado o bom relacionamento da sociedade dominante com a instituição financeira), a imposição de celebração de um contrato com terceiro do qual a sociedade dominada obtenha um benefício, ou a venda, para a sociedade dominada, de determinado insumo necessário à sua atividade produtiva a preços inferiores aos que a sociedade dominada obteria no mercado.

A adoção de tais medidas que resultem em benefício para a sociedade dominada não necessariamente implicam em prejuízo para outra sociedade. Se for este o caso, duas são as possibilidades: ou acarreta-se um prejuízo para a sociedade dominante, ou acarretase um prejuízo para outra sociedade que também seja dependente da sociedade dominante. Se o prejuízo for sofrido pela sociedade dominante, aplicam-se as regras de responsabilidade dos administradores (no direito brasileiro, art. 159, LSA). Se o prejuízo por sofrido por outra sociedade dependente, aplicam-se a esta as conseqüências descritas abaixo para os casos em que a ingerência externa é negativa.

A ingerência externa neutra é aquela que não causa prejuízos ou benefícios para a sociedade dominada do ponto de vista patrimonial. Geralmente, estas ingerências são mais relacionadas à organização interna da sociedade dominada. De fato, para que se fale em classificar a ingerência exercida pela sociedade dominante em positiva, negativa ou neutra, o efeito causado na sociedade dominada deve ser calculável. ${ }^{123}$

Quando se fala em ingerência que causa um efeito negativo na sociedade dependente, a questão muda de figura. A ingerência que causa um efeito negativo na sociedade dominada é aquela que acarreta prejuízo, diminuição patrimonial para esta sociedade. Segundo o princípio jurídico de que aquele que causar dano a outrem tem o dever de indenizá-lo (art. 186 e 187, combinados com art. 927 do Código Civil), conclui-se que a sociedade dominante, sempre que causar prejuízo à sociedade dependente, terá o dever de reparar o dano causado.

No caso de sociedades sujeitas ao exercício de influência dominante por parte de outra sociedade, os principais prejudicados no caso de ingerência negativa da sociedade dominante são os credores e os acionistas minoritários.

${ }^{123}$ ARRIBA FERNÁNDEZ, 2004, p. 151-156. 
Para Arriba Fernández, o dano causado pela sociedade que exerce a influência dominante afeta os acionistas minoritários não infratores na medida em que estes têm reduzidos seus benefícios decorrentes da participação no capital social da sociedade dominada. Com relação aos credores, embora também sejam afetados - afinal, possuem interesse da integridade patrimonial da sociedade da qual são credores - a capacidade de reação é ainda mais reduzida se comparada aos acionistas minoritários.

\begin{abstract}
Por eso, sus esperanzas pasan por los mecanismos de que dispone el sujeto pasivo del daño para exigir para la debida compensación. Sólo en aquellos casos en los que los directamente perjudicados no reclamen la indemnización del daño causado, bien por no querer, bien por no existir [...], surgirá un derecho en beneficio de los credores sociales que, de otra forma, se verían totalmente desprotegidos. $^{124}$
\end{abstract}

Eis a razão do dever de indenizar, que para a autora espanhola citada anteriormente é um reflexo do dever de fidelidade que rege as relações societárias. Especialmente no caso das uniões de sociedades, a sociedade dominante deve exercer a influência dominante de que dispõe respeitando o fim comum e também o interesse dos sócios minoritários. " $Y a$ tal efecto se considerará desleal una medida, un comportamiento o una actuación, aun cuando no dé lugar a un menoscabo patrimonial en la sociedad dependiente, siempre y cuando no se atenga a los límites marcados por el fin común y el objeto social."125

Disposições neste sentido podem ser encontradas no direito brasileiro. Para Adamek, o legislador brasileiro reconheceu a possibilidade de sociedades atuarem de forma coordenada (e, para este autor, o legislador não teria a condição de impedir tal fato), mas estabeleceu condições a serem observadas pelos administradores para tanto. Assim, existe um verdadeiro dever geral de lealdade aos administradores das sociedades no âmbito grupal, segundo o qual os administradores não podem, em prejuízo da companhia, favorecer sociedade controlada, coligada ou controladora, zelando para que operações firmadas com tais sociedades obedeçam condições estritamente comutativas ou com pagamento compensatório adequado. "O descumprimento desse específico dever de lealdade no âmbito grupal poderá fundamentar a propositura de ação social de responsabilidade civil para indenizar a sociedade prejudicada pela atuação desleal de seu

${ }^{124}$ ARRIBA FERNÁNDEZ, 2004, p. 157.

${ }^{125}$ Ibid., p. 163. 
administrador [...]". Entretanto, o próprio autor reconhece que na prática é difícil verificar se as operações de fato atendem a condições comutativas. ${ }^{126}$

2.2.2.5 Influência dominante e direção unitária: conceitos distintos ou pressuposto um do outro?

A análise do conceito e características da situação de dependência entre sociedades e o exercício de influência dominante é relevante e necessária para a análise do conceito de direção unitária, elemento essencial aos grupos de sociedades. Mas em que medida os conceitos de influência dominante e direção unitária se relacionam?

Como descrito anteriormente, o grupo de sociedades caracteriza-se pela integração de várias sociedades com personalidades jurídicas distintas, unidas por uma direção comum. É a direção unitária que confere aos grupos a sua unidade econômica.

A influência dominante pode ser o elemento que dá origem à direção unitária, como se verá adiante. Isso, contudo, não é uma regra. Arriba Fernández explica o porque:

[...] hemos de recordar que la dependencia no constituye un elemento esencial del concepto de grupo, sino solo una nota característica de una clase concreta de grupos, a saber, de los grupos por subordinación. En consecuencia, centrar el estudio de los grupos de sociedades en el concepto de dependencia o en el control, no es acertado por dos razones: por un lado, porque confunde dos situaciones distintas que generan problemas diferentes (el grupo y la dependencia), aunque con una raíz común; y, por otro lado, porque implica negar la condición de grupo a aquellas situaciones en las que la unión de las diferentes sociedades agrupadas se entabla sobre la base de una dirección unitaria concordada (grupos por coordinación) y no sobre la de una dependencia que desemboca en una dirección unitaria impuesta (grupos por subordinación). En otras palabras, pode haber grupo sin dependencia, pero no sin dirección unitaria. [...] Sin dirección unitaria, es decir, sin la planificación conjunta de las actividades de las sociedades agrupadas, no habrá grupo. ${ }^{127}$

De fato, se considerarmos os grupos por coordenação, pode-se afirmar que não há,

126 ADAMEK, Marcelo Vieira Von. Responsabilidade Civil dos Administradores de S/A e as Ações Correlatas. São Paulo: Saraiva, 2009, p. 157-158.

127 ARRIBA FERNÁNDEZ, 2004, p. 199. 
em princípio $^{128}$, situação de dependência entre as sociedades agrupadas. A direção unitária exercida sobre as sociedades integradas no grupo foi acordada entre as sociedades participantes $^{129}$, afastando desta forma a situação de dependência.

Não obstante, já destacamos que esta dissertação foca nos grupos de fato por subordinação e é com vista neles que se analisará a questão da direção unitária nas linhas que seguem. Nos grupos de fato por subordinação, não se pode dissociar a figura da influência dominante da figura da direção unitária, na medida em que a primeira acaba sendo pressuposto da segunda. Ao passo que nos grupos de coordenação a direção unitária é acordada, nos grupos por subordinação à direção unitária é imposta pela sociedade dominante às sociedades dominadas em decorrência do exercício da influência dominante $^{130}$.

Não por coincidência, os mecanismos que dão origem a uma situação de dependência entre duas sociedades - e, conseqüentemente, ensejam o exercício de influência dominante (vide item 2.2.2.2 supra) - são exatamente os mesmos mecanismos que permitem o nascimento da direção unitária que caracteriza os grupos de sociedades.

A principal distinção que pode ser feita entre a influência dominante e a direção unitária é que ao passo que a primeira possui um caráter potencial, como foi dito no item 2.2.2.1, a segunda deve ser efetivamente exercida. Em outras palavras, a influência

${ }^{128}$ Diz-se em princípio, pois, como visto anteriormente, as possibilidades de arranjos fáticos para a composição de grupos de sociedades são incontáveis.

${ }^{129}$ Para o direito brasileiro, no qual os grupos de coordenação são tipificados na figura dos consórcios, vide art. 278 e seguintes da LSA.

130 Embora o exercício de influência dominante pela sociedade controladora sobre as sociedades controladas seja notória na realidade fática dos grupos de fato por subordinação, a LSA não reconhece expressamente a figura da influência dominante. Não obstante, essa idéia pode ser implicitamente observada em alguns diplomas do nosso ordenamento. João Henrique Guidugli aponta expressamente o art. 520 do Decreto $\mathrm{n}^{\circ}$ 87.981/82 (Regulamento do Imposto Sobre Produtos Industrializados), que traz um conceito de empresas interdependentes, e a Lei $\mathrm{n}^{\mathbf{0}} 7.232 / 84$, que dispunha sobre a antiga política nacional de informática, que estabelecia, para os fins daquela norma, que o controle de uma sociedade sobre outra seria, decisório, tecnológico ou de capital. A própria LSA traria um indício do conceito de influência dominante em seu art. 249, ao determinar que a CVM, ao expedir normas sobre consolidação de informações em demonstrações financeiras, pode determinar a inclusão de informações sobre sociedades que "embora não controladas, sejam financeiramente ou administrativamente dependentes da companhia" (2006, p. 68-73). Vide também, em certa medida, as definições de "empresa vinculada", dispostas no art. 23 da Lei 9.430/96, que dispõe sobre a legislação tributária federal, as contribuições para a seguridade social e o processo administrativo de consulta. Teria esta lei reconhecido implicitamente a influência dominante ao considerar como empresa vinculada a pessoa jurídica residente no Brasil, por exemplo, "a pessoa física ou jurídica, residente ou domiciliada no exterior, que goze de exclusividade, como seu agente, distribuidor ou concessionário, para a compra e venda de bens, serviços ou direitos"? 
dominante possui caráter ocasional, e a direção unitária deve ser exercida de forma contínua para se caracterizar como tal.

A mera possibilidade de exercício de influência dominante não é apta para criar a direção unitária e, por conseguinte, não faz surgir um grupo de sociedades. A direção unitária se concretiza com uma série de instruções emanadas pela sociedade dominante cujo cumprimento pelas sociedades dominadas deve ser obrigatório, a fim de que as atividades desenvolvidas pelas sociedades integrantes do grupo sejam coordenadas, objetivando uma finalidade comum. Não obstante esta distinção com relação à efetividade do exercício, a direção unitária, assim como a influência dominante, deve possuir um caráter estável. $^{131}$

Quando se fala no alcance da direção unitária, a discussão é bastante semelhante à questão do alcance da influência dominante. E esta é justamente uma das principais dificuldades de se conceituar a direção unitária.

A sociedade individualmente considerada possui poder de autodeterminação na condução de suas atividades, mas a integração da sociedade em um grupo representa a perda de sua independência econômica originária, por meio da transferência das competências de gestão empresarial para a sociedade de comando do grupo. Sendo assim, a idéia de direção unitária estaria associada a um processo de transferência da soberania decisória individual das várias sociedades grupadas para a sociedade de comando, com a conseqüente centralização do poder de direção da atividade empresarial nesta sociedade de comando. $^{132}$

Esta centralização do poder de direção, contudo, comporta diversos graus e é justamente nisso que reside a dificuldade de conceituação da direção unitária. Um grupo de subordinação constitui-se por meio de relações de controle entre a sociedade de comando e as sociedades filiadas. Sendo assim, até que ponto a relação de controle entre as empresas é uma mera coligação de sociedades com finalidade de investimento e aplicação de capitais e até que ponto a sociedade de comando exerce direção unitária entre as empresas controladas, caracterizando um grupo de sociedades?

Antunes destaca alguns aspectos econômicos e jurídicos relativos a esta questão.

131 ARRIBA FERNÁNDEZ, 2004, p. 201-206.

132 ANTUNES, 2002, p. 113-114. 
Sob um ponto de vista econômico, a direção unitária traduz-se pela existência de uma política econômico-empresarial geral e comum para todas as sociedades integrantes do grupo, emanada pela sociedade de comando, que incidiria sobre diversos aspectos setoriais do funcionamento de cada uma das sociedades grupadas, tais como políticas comercial, financeira, laboral, de gestão etc. A adoção desta política econômicoempresarial geral e comum asseguraria a coesão econômica de todas as sociedades integrantes do grupo, já que todas as políticas individuais destas estariam submetidas à política geral emanada pela sociedade de comando.

Contudo, o conteúdo concreto desta política geral, bem como o alcance das restrições, eventualmente impostas às sociedades filiadas, nestes casos varia de grupo para grupo, dependendo do seu grau de centralização ou descentralização. ${ }^{133}$ Como a realidade varia muito conforme o caso concreto, não é difícil perceber a dificuldade de conceituação da direção unitária. Como salienta Prado:

\begin{abstract}
Em virtude da extrema dificuldade de estabelecer o conteúdo da direção unitária para os fins da configuração dos grupos e respectiva aplicação de regras próprias, é controvertida e discutível a utilização de tal conceito na lei. A dificuldade está em estabelecer, ao menos, os elementos mínimos desta expressão importada da ciência econômica capazes de abarcar as situações diversas e as estruturas societárias também bastante diferentes." 134
\end{abstract}

Antunes cita alguns exemplos da implementação de uma política geral aos principais setores das sociedades grupadas.

Uma política comercial uniforme, por exemplo, é apontada por este autor como "a condição mínima da existência de um grupo”. Especialmente em mercados globalizados e com a internacionalização do consumo, é fácil verificar a existência de grupos de sociedades com marcas uniformes (não raro mundialmente) e com estratégias de publicidade e de vendas também uniformes.

Outro aspecto relevante para a identificação de uma política geral do grupo é a unidade de política financeira. Com a centralização das decisões financeiras das sociedades grupadas, controla-se indiretamente a gestão de cada uma das sociedades filiadas e este

\footnotetext{
133 ANTUNES, 2002, p. 114-115.
}

134 PRADO, 2006, p. 116. 
instrumento é quase imprescindível para garantir a coesão econômica da atividade das empresas grupadas. Se a política financeira é coordenada pela sociedade de comando, que possui uma visão geral da atividade do grupo, sem dúvida que esta resultará mais funcional e eficaz, garantindo a unidade econômica de todas as empresas filiadas.

Por fim, Antunes destaca a política de gestão unitária. Esta pode ser exercida de diversas formas, desde a planificação ou até a mera fiscalização das atividades desenvolvidas pelas sociedades filiadas. ${ }^{135}$

\begin{abstract}
[P]articularmente conhecidas a este propósito são as práticas que consistem na fixação de sectores de actividade da sociedade-filha cuja gestão está interdita à sua própria administração [...], no estabelecimento pela sociedade-mãe de um 'plafond' ou limite monetário máximo para além do qual a filial não está autorizada a realizar transacções comerciais ou qualquer espécie de vinculação no mundo dos negócios sem a prévia aprovação daquela [...], ou até mesmo, finalmente, na distribuição aos administradores e directores das filiais de guias de instrução e manuais de gestão ('rules books'), que contêm directivas concretas, por vezes muito detalhadas e incidindo sobre um grande número de situações sobre os próprios metidos, 'standards', e sentidos das decisões de administração social. ${ }^{136}$
\end{abstract}

Todos os aspectos descritos acima auxiliam na identificação da direção unitária, mas são aspectos verificados apenas na realidade empresarial. Sob um ponto de vista jurídico, é extremamente difícil enquadrar a situação fática descrita anteriormente, visto que, como já mencionado, as variantes no caso concreto são incontáveis.

Sendo assim, não apenas as legislações que prevêem expressamente a direção unitária como elemento caracterizador dos grupos de sociedade ${ }^{137}$ evitam conceituá-la, mas a própria doutrina não consegue chegar a uma definição jurídica do termo que abarque todas as possibilidades.

Em vista dessa dificuldade, a doutrina vem se concentrando na identificação do que seria o "conteúdo mínimo" que caracterizaria a direção unitária. Em outras palavras,

[...] a questão crucial consiste em identificar aquele limiar mínimo de

135 ANTUNES, 2002, p. 114-119.

136 Ibid., p. 119-120.

137 Tais como a alemã e a portuguesa. 
centralização das competências decisórias empresariais, além do qual existirá uma simples relação de domínio intersocietário, e além do qual já se poderá falar de uma direcção unitária e, por conseguinte, de uma verdadeira relação de grupo. ${ }^{138-139}$

Antunes e Castellões demonstram a existência de duas correntes majoritárias. A primeira delas adota uma acepção estrita do conceito de direção unitária, segundo a qual a centralização da política financeira das sociedades pertencentes ao grupo é condição necessária e suficiente para a caracterização da direção unitária. A segunda adota uma concepção ampla do conceito: estar-se-á diante de uma estrutura de direção unitária quando a sociedade de comando detiver poder de direção central não apenas sobre a política de finanças da sociedade filiada, mas sobre qualquer das outras áreas funcionais da gestão empresarial das sociedades filiadas, tais como as políticas de gestão, de pessoal, comercial etc., desde que a referida centralização tenha resultado na perda da independência econômica (que pode ser parcial) da sociedade-filha. ${ }^{140}$

Para os fins deste trabalho, adotar-se-á a segunda acepção descrita. Tendo em mente que o foco desta dissertação será os grupos de fato previstos no direito brasileiro, que são, basicamente, grupos de subordinação constituídos por relações de controle e coligação entre a sociedade de comando e as sociedades filiadas, salienta-se que tais formas de organização dos grupos compreendem as mais variadas formas e os mais distintos graus de centralização. Na realidade fática, é possível a existência de unidade

138 ANTUNES, op. cit., p. 121.

139 "La determinación del concepto de dirección unitaria exigirá, pues, establecer al contenido mínimo de competencias empresariales cuya 'transferencia', de las sociedades dependientes a la sociedad dominante, dé lugar a la existencia de un solo sujeto económico, de una nueva empresa, sin perjuicio de la aparente 'diversidad' que sugiere el mantenimiento de la autonomía jurídica de las sociedades del grupo." (EMBID IRUJO, 1984a, p. 155-156).

140 Conforme ANTUNES, 2002, p. 121-122; CASTELLÕES, 2008, p. 87. No mesmo sentido, Viviane Muller Prado: "Em razão dessa discussão doutrinária, são duas as concepções da expressão direção unitária. A primeira tem uma acepção estrita do termo e, portanto, conforme o pensamento da Teoria da Unidade, Konzern corresponderia à forte unidade econômica, com um plano único e centralizado para todas as empresas do grupo, de forma a desconsiderar a autonomia das sociedades isoladas. Para os que defendem esta posição, o campo principal de atuação é a área financeira. Nessa visão, somente diante de forte unidade empresarial justificar-se-ia falar em Konzern. Outra parte da doutrina entende que a direção unitária pode caracterizar-se em outras áreas (comercial, gestão, pessoal), desde que represente uma repercussão no todo da empresa e retire da sociedade controlada a sua independência, ainda que parcialmente." (2006, p. 115-116). Observação semelhante é feita por ARRIBA FERNÁNDEZ, 2004, p. 208-210 e FUENTES NAHARRO, 2007, p. 117-120, embora esta última autora entenda que o conteúdo mínimo da direção unitária inclua não só a política financeira, mas também a de pessoal. 
econômica nos grupos de fato, ainda que esta unidade não diga respeito à política financeira das empresas integrantes do grupo. ${ }^{141}$

\subsubsection{Direção unitária e interesse do grupo}

O exercício da direção unitária no seio dos grupos de sociedades faz nascer um conflito que Arriba Fernández considera paradigmático: o conflito entre o interesse do grupo e o interesse de cada uma das sociedades grupadas.

As teorias que discutem o interesse da sociedade normalmente dividem-se em duas correntes: a contratualista, segundo a qual o interesse social se identifica com o interesse comum dos sócios, e a institucionalista, segundo a qual o interesse social é um interesse próprio da sociedade e distinto do interesse dos membros que a compõem. ${ }^{142,143}$

Independente da corrente doutrinária adotada, é pacífica a idéia de que a sociedade possui um interesse próprio, que não se confunde com o interesse particular de cada um de seus sócios. Assim, nas sociedades isoladas, como demonstra Schmidt, aquele que detém o controle da sociedade deve exercê-lo no interesse da sociedade.

${ }^{141}$ Muito embora Embid Irujo sustente que não obstante as estruturas de grupo possam assumir um caráter de substancial descentralização, esta descentralização da estrutura organizativa do grupo não pode chegar ao ponto de colocar em risco a unidade econômica do mesmo; e sem uma política financeira unitária (que geralmente vem acompanhada de uma política unitária de pessoal), dificilmente se poderá falar em unidade econômica, em direção unitária e, conseqüentemente, em grupo de sociedades. (EMBID IRUJO, 1984a, p. 158). A mesma observação, com a qual se concorda, é feita por Arriba Fernández: "es difícilmente imaginable que los sectores empresariales esenciales estén sometidos a una planificación común, sin que el sector financiero se encuentre a su vez sometido a una planificación unitaria." (2004, p. 209-210).

142 ARRIBA FÉRNANDEZ, 2004, p. 213-214.

143 Sobre as teorias contratualistas e institucionalistas a respeito do interesse social, vide SALOMÃO FILHO, Calixto. O Novo Direito Societário. 3. ed. São Paulo: Malheiros, 2006, p. 26-38. Para este autor, contudo, modernamente a questão do interesse social é melhor explicada pela teoria do contrato organização, segundo a qual o interesse social identifica-se "à melhor organização possível do feixe de relações envolvidas pela sociedade" (p. 42-48). "De fato, a teoria organizativa, com todos os ganhos em custos de transação e eficiência que sua aplicação criteriosa pode propiciar, é sem dúvida a mais apta a garantir a lucratividade dos sócios, tão almejada pelos contratualistas. Por outro lado, a mesma capacidade de organização das relações a ela submetidas, proporcionada pela teoria do contrato organização, tem a capacidade de transformar a sociedade naquela célula social propulsora do desenvolvimento tão almejada pelos institucionalistas desde Rathenau.” (p. 49). 
L'usage du contrôle n'est pas discrétionnaire. Il doit servir l'intérêt commun des actionnaires, et non l'intérêt de celui qui le détient au préjudice des autres. Le patrimoine social appartient, par-delà la personne morale, à tous les actionnaires ey n'a pas vocation à enrichir un seul d'entre eux. Telle est la signification de l'autonomie patrimoniale dans les rapports entre actionnaires: l'exploitation des biens sociaux s'opère en vue de l'enrichissement collectif, elle est confiée à celui qui, par l'importance de sa participacion, détient le contrôle. En conséquence, ce dernier ne pourrait exploiterle patrimoine social à des fins strictement personnelles sans violer l'autonomie patrimoniale de la société. ${ }^{144}$

Nas sociedades integradas em um grupo, o exercício da direção unitária pela sociedade de comando faz nascer, paralelamente ao interesse de cada uma das sociedades dominadas, o chamado "interesse do grupo". Sendo o grupo de sociedades uma unidade econômica, na qual todas empresas grupadas atuam sob o comando da sociedade dominante para a consecução de um fim comum, o interesse grupal

[...] es el parámetro que ha de guiar a la sociedad matriz en la dirección del grupo de la misma manera que el interés social guía a los socios y a los administradores de una sociedad en el desarrollo de la actividad social [...]; el interés del grupo se manifestará en la búsqueda del máximo beneficio del conjunto, aunque no necesariamente para todos los miembros del colectivo grupal. En otras palabras, y a semejanza de lo que ocurre en cualquier empresa, globalmente considerado el grupo busca la máxima rentabilidad, la obtención del máximo beneficio, aunque para ello haya de perjudicar a alguno de sus miembros. " 145

Importante destacar que embora a sociedade de comando do grupo exerça a direção unitária, no sentido de perseguir o interesse do grupo, o interesse do grupo não necessariamente será coincidente com o interesse da sociedade de comando. ${ }^{146}$

Schmidt indica que o interesse do grupo deve ser analisado sob três acepções distintas: o interesse do grupo, o interesse da sociedade que controla o grupo e o interesse das sociedades que integram o grupo.

No primeiro caso, o interesse do grupo poderia ser definido como um interesse "superior", que transcende o interesse de cada uma das sociedades-membro do grupo, almejando o benefício geral de todas elas. O interesse do grupo, todavia, não seria

144 SCHMIDT, Dominique. Les Conflits d'Intérêts dans la Société Anonyme. Paris: Joly, 2004, p. 414.

145 ARRIBA FÉRNANDEZ, 2004, p. 215.

146 Embora María Luisa de Arriba Férnandez ensine que alguns autores alemães sustentem que o titular do interesse do grupo seria a sociedade matriz (Ibid., p. 215). 
reconhecido pelo direito positivo devido a algumas reservas, tais como a ausência de uma definição precisa do conceito de interesse do grupo, o fato de o interesse do grupo não excluir o interesse da sociedade individualmente considerada, e o fato de o interesse do grupo acabar emanando não das sociedades grupadas, mas sim, em última análise, da vontade da sociedade que detém o controle do grupo.

No que diz respeito ao interesse da sociedade controladora, Schmidt salienta que o interesse do grupo não se confunde com o interesse das sociedades grupadas. Entretanto, numa estrutura de grupo a sociedade controladora possui grande facilidade de dispor do patrimônio das sociedades grupadas, o que demonstra a fragilidade na distinção entre o interesse do grupo e o interesse da sociedade controladora.

Por fim, a terceira acepção seria aquela na qual o interesse do grupo exprime o interesse de cada uma das sociedades-membro, onde cada sociedade controlada, espelhando a sociedade controladora, exerceria seu interesse no interesse das demais sociedades grupadas. O problema desta acepção é que o interesse de cada sociedade compreende não apenas o interesse do acionista majoritário, mas também dos acionistas ditos "externos" 147 . Sendo assim, "le contrôle qu'un actionnaire exerce sur un groupe a pour finalité et pour limite l'intérêt de tous les actionnaires."

Em suma, as sociedades integradas ao grupo, dotadas de personalidade jurídica distinta, possuem cada uma seu próprio interesse social. Exceto nos casos em que o ordenamento jurídico prevê regulação sistemática do direito dos grupos, autorizando de certa forma a subordinação dos interesses das sociedades controladas aos interesses do grupo $^{149}$, não há autorização legal para a subordinação dos interesses de cada uma das sociedades controladas ao interesse do grupo.

Em vista disso, Jaeger chega a questionar a utilidade da discussão a respeito do interesse do grupo:

${ }^{147}$ SCHMIDT, 2004, p. 418-419.

${ }^{148}$ Ibid., p. 420.

${ }^{149}$ É o caso do direito alemão e, também, o do direito brasileiro. No direito pátrio, a celebração de uma convenção de grupo autoriza a subordinação dos interesses das sociedades controladas ao interesse da sociedade de comando do grupo, nos termos do art. 266 da LSA. Sobre este aspecto, vide GUERREIRO, José Alexandre Tavares. Conflitos de Interesse entre Sociedade Controladora e Controlada e entre Coligadas, no Exercício do Voto em Assembléias Gerais e Reuniões Sociais. RDM, ano XXII, n. 51, p. 29-32, jul./set. 1983, p. 32. 
A tale orientamento si è pero replicado che affermare che l'interesse di gruppo in tanto può essere perseguito in cuanto non incida sull'interesse delle singole società che esso deve essere ulteriore ma non confliggente, rispetto all'interesse delle controllate, significa in relata asserire l'irrelevanza dell'interesse di gruppo neel'ambito del diritto societario vigente. Sostenere, in altre parole, la legitimità dell'interesse di gruppo a condizione che esso rimanga esterno, ininfluente e separato rispetto all'interesse delle singole società, equivale ad affermare la legitimità del perseguimiento de qualunque interesse extrasociale, purché questo non incida per nulla sull'interesse sociale, tradizionalmente inteso. ${ }^{150}$

Embora o interesse do grupo, na teoria, não possa suplantar o interesse das sociedades individuais, isso acontece - e muito - na realidade fática dos grupos de sociedades. ${ }^{151}$. Como resultado, nos grupos de fato instaura-se uma contínua situação de conflito de interesses. ${ }^{152}$

Segundo Fuentes, em uma situação de grupo de sociedades, a direção unitária se opera por meio de uma rede hierarquizada protagonizada pelos membros dos órgãos de administração das sociedades controladas, que atuarão seguindo as ordens emanadas pela administração da sociedade de comando, que geralmente é a titular da direção unitária do grupo. A execução da política econômica do grupo fica, portanto, nas mãos da administração das sociedades grupadas, deixando à assembléia geral das sociedades dominadas um papel de menor relevância.

Esta situação abala a estrutura tradicional da sociedade isolada do direito clássico, baseada na soberania da assembléia geral.

Así, la integración de una sociedad en una empresa policorporativa de grupo plantea una situación bastante paradójica, inexplicable desde la perspectiva del modelo clásico de la sociedad-isla observado por nuestro ordenamiento: el

${ }^{150}$ JAEGER, Pier Giusto. L'Interesse Sociale Rivisitato (quarant'anni dopo). Giurisprudenza Commerciale, Milano, n. XXVII, parte I, fasc. 1, p. 795-812, 2000, p. 810.

151 ARRIBA FÉRNANDEZ, 2004, p. 216.

152 '[...] cuando una sociedad se incorpora o 'nace' en un grupo, el interés social propio deja de ser - en el ámbito empresarial sobre el que recae esa dirección unitaria - el criterio de actuación al que se atienen sus órganos para pasar a ser sustituido por el interés del conjunto, el interés del grupo. Por eso la doctrina entiende que el sometimiento de una sociedad integrada en un grupo a la dirección unitaria ejercida por uno de sus miembros representa inevitablemente una contradicción entre la Ley y realidad económica ('un divorcio entre la norma y la realidad'). Esta contradicción se traduce en que la existencia de una gestión unificada pone a los administradores de una sociedad integrada en un grupo en una situación de continuo conflicto de intereses." (FUENTES NAHARRO, 23007, p. 81-82). 
poder de gobierno de la sociedad no puede ser localizado en sus propios órganos (rectius, únicamente en sus propios órganos). ${ }^{153}$

Em vista do acima, a doutrina debruça-se na tentativa de responder a seguinte questão: não existindo um instrumento jurídico que permita ou legitime a subordinação do interesse das sociedades grupadas ao interesse do grupo (como é o caso dos grupos de fato por subordinação, objeto deste estudo), quais são os pressupostos ou condições que autorizam a submissão do interesse particular de cada uma das sociedades ao interesse do grupo ${ }^{154}$

Para Lamy Filho e Pedreira, o interesse do grupo não substitui, mas se superpõe ou acresce ao interesse social de cada sociedade isolada integrante do grupo. Seria o interesse conjunto de cada uma das sociedades do grupo de cooperarem, otimizando os resultados e participando dos benefícios obtidos da atividade comum. Para o autor, o interesse do grupo seria o ponto de equilíbrio entre o interesse da controladora e o interesse particular das sociedades controladas, e "negar esta realidade significa propor, no plano da teoria jurídica, um modelo de empresa que não existe." Assim, a persecução do interesse do grupo implicaria em uma delimitação do comando legítimo emitido pela sociedade controladora e o abuso de poder. ${ }^{155}$

${ }^{153}$ Ibid., p. 79-80. Galgano sustenta que a disciplina do conflito de interesses deve ser interpretada, para as sociedades integradas em grupos, de forma compatível com o fenômeno. Se a sociedade controladora for simplesmente impedida de votar nas deliberações sociais da controlada onde tenha interesse conflitante (conflito de interesses em abstrato), os grupos de sociedade podem ter sua estrutura abalada. Deve haver uma avaliação dos interesses em jogo, sendo analisados não apenas o interesse das sociedades envolvidas, mas também o interesse do grupo ao qual as sociedades pertencem (GALGANO, 2003, p. 102).

${ }^{154}$ A problemática é bem sintetizada por Pereira: "Se, por um lado, é forçoso afirmar que o interesse do grupo e os interesses particulares das sociedades controladas não são sempre, nem necessariamente, antagônicos, não é possível, por outro lado, desconhecer o conflito potencial em que podem encontrar-se em determinadas situações e cuja solução é o motivo principal que dá origem à legislação dos grupos. Como tarefa indispensável para qualquer regulação dos grupos, aparece, em conseqüência, a necessidade de se proceder a um equilíbrio entre os interesses surgidos em certas ocasiões como contrapostos, pois, do contrário, uma acentuação do reconhecimento do interesse do grupo acarretaria uma desproteção de outros interesses dignos de tutela (sócios minoritários, credores, trabalhadores etc.), da mesma forma que, em sentido inverso, uma tutela exagerada destes últimos privará de viabilidade o grupo como tal." (PEREIRA NETO, 1991, p. 30).

155 LAMY FILHO, Alfredo; PEDREIRA, José Luiz Bulhões (CoordS.). Direito das Companhias. Rio de Janeiro: Forense, 2009. vol. II, p. 1937-1938. Galgano no mesmo sentido: "[...] il fatto di ubiddire alle directive della holding non implica necessariamente 'la subordinazione degli interesse delle controlatte ad interessi estranei', giacché le controllate traggono vantaggio dalla appartenenza al gruppo [...]. [I]l puro e semplice rapporto di gruppo fra due società non giustifica di per sé solo il sacrificio delle'interesse dell'una per il vantaggio dell'altra, occorrendo pure sempre un interesse, anche se indiretto e mediato, della società che si obbliga per la società sorella, salvo che lo svantaggio non trovi una compensazione." (GALGANO, 2003, p. 82-83). 
Eis a dificuldade. A doutrina parece ainda não ter encontrado uma forma de determinação precisa deste limite. O que se pode afirmar é que a persecução do interesse do grupo pode acarretar em prejuízos para uma ou várias sociedades grupadas ${ }^{156}$, em benefício do grupo como um todo. Se isso é verdade, os prejuízos causados nessa situação somente são justificados se servirem ao interesse do grupo. Caso contrário, serão considerados ilícitos. Se eles servem ao interesse do grupo, necessitam ser adequadamente compensados às sociedades que "sacrificaram-se" em benefício da coletividade. ${ }^{157}$

Esta compensação adequada, contudo, parece ser o principal problema que os grupos de sociedade enfrentam. Como calculá-los e efetivar a sua compensação? A doutrina ainda não possui resposta para esta questão. ${ }^{158}$ Como bem define Embid Irulo, "hablar de 'los grupos de sociedades como problema jurídico' significa, en esencia, admitir que dichas estructuras de la realidad empresarial de nuestros días constituyen un problema básico para el Derecho"159

156 Prejuízos estes que atingem não só a própria sociedade, mas também seus acionistas minoritários e credores.

157 Conforme ARRIBA FÉRNANDEZ, 2004, p. 219-220. No mesmo sentido: “Todas as sociedades que integram o grupo de fato - principais ou acessórias, líderes ou lideradas, maiores ou menores - auferem benefícios da vinculação ao grupo porque este - como todo - é maior do que a soma das partes; e são várias as modalidades de cooperação e apoio mútuos que uma sociedade pode prestar a outra sem prejuízo para seu patrimônio nem redução dos lucros de que participam seus acionistas minoritários. Se a formação do grupo permite que o conjunto obtenha benefícios econômicos que não podem ser alcançados de outro modo, o único limite à cooperação e apoio mútuo que se justifica, como meio de proteger os acionistas minoritários e credores, é o de que ao sejam causados prejuízos a uma sociedade para atender ao interesse da outra." (LAMY FILHO; PEDREIRA, 2009, p. 1939). Ainda: “[...] any regulation of corporate groups should establish legitimacy for the promotion of interests and legal safety for the group's specific operations, but measures will also have to be put forward to protect those that may suffer from the primacy of the group's interests over those of the constituent companies." (EMBID IRUJO, José Miguel. Trends and Realities in the Law of Corporate Groups. European Business Organization Law Review, n. 6, p. 65-91, 2005, p. 69-70). Vide também LOBO, Carlos Augusto da Silveira; NEY, Rafael de Moura Rangel. conflito de interesses entre o administrador e a companhia - inexistência de impedimento de votar em deliberação do conselho de administração da controlada, do qual é membro, que aprova concessão de mútuo à controladora, da qual é Chefe do Departamento Jurídico. RDM, n. 144, p. 275-286, out./dez. 2006, p. 281-285.

158 Nos grupos de fato, principalmente: "In the de facto group, the parent is not allowed to induce its subsidiary to enter into disadvantageous transactions unless compensation is granted for such disadvantage in the same financial year. Where the parent fails to compensate, the subsidiary can claim for consequential damages. However, although de facto group concept is straightforward in theory, the practical difficulties in establishing the parent's liability have proved to be enormous." (BICKER, 2006, p. 4). Vale destacar que este autor fala da compensação da sociedade de comando pelos prejuízos causados à sociedade dominada num contexto de direito alemão.

${ }^{159}$ EMBID IRUJO, 2003, p. 1. 


\subsubsection{A disciplina dos grupos de sociedades}

Feitas as considerações anteriores, sobre a direção unitária como elemento caracterizador dos grupos de sociedade, cumpre analisar os principais aspectos da disciplina desta figura empresarial.

\subsubsection{Sistemas de regulação dos grupos no direito comparado}

Arriba Fernández indica que o objetivo da regulação dos grupos de sociedade consiste no reconhecimento jurídico da constituição e organização desta figura empresarial, legitimando o exercício da direção unitária sobre as sociedades dominadas e a primazia do interesse do grupo sobre o interesse de cada uma das sociedades agrupadas. Além disso, a regulação teria o objetivo de determinar mecanismos de tutela das sociedades dependentes, seus sócios e seus credores, mecanismos estes que deveriam substituir os mecanismos de proteção do direito comum (aplicável às sociedades isoladas). ${ }^{160}$

Antunes divide os sistemas de regulação dos grupos de sociedade em três grandes correntes: (i) o entity law approach da doutrina norte-americana; (ii) o enterprise approach da doutrina européia; e (iii) o dualist approach da doutrina alemã. ${ }^{161}$ Como bem observado por Munhoz, embora a abordagem de Antunes diga respeito especificamente à responsabilidade das empresas grupadas perante os credores, a classificação proposta pelo autor português é adequada para classificar os sistemas de regulação dos grupos no que diz respeito a diversos outros aspectos, tais como a proteção dos minoritários. ${ }^{162}$

\subsection{O modelo clássico norte-americano}

\footnotetext{
160 ARRIBA FERNÁNDEZ, 2004, p. 36.

161 ANTUNES, 1994, p. 231.

162 MUNHOZ, 2002, p. 263-264.
} 
Iniciando pela abordagem do entity law approach, Antunes indica que para a doutrina norte-americana a independência das sociedades seria um princípio fundamental: "one member of a corporate group, namely the parent corporation, cannot be made liable for the debts or the acts of another group member for the reason that they are distinct legal entities."163 Como explica Munhoz, a doutrina norte-americana entende que cada sociedade do grupo é um sujeito de direito distinto e juridicamente independente, segundo os princípios do direito societário clássico. Assim, cada uma das sociedades grupadas possui patrimônio e organização autônomos, não podendo a sociedade controladora ser responsabilizada por débitos das sociedades controladas. Os grupos são mero conjunto de sociedades e aplicam-se a eles as mesmas regras do direito societário clássico (o das sociedades isoladas). ${ }^{164}$ Em vista disso, não há regras específicas de responsabilidade ou proteção aos credores das empresas grupadas.

Para Arriba Fernández, a opção pela não regulação dos grupos de sociedades, sem a criação de um regime jurídico distinto do direito comum de sociedades (onde os Estados Unidos são caso paradigmático) é uma decisão política. Para a autora, isso se dá porque acredita-se que um direito global de grupos seria ineficiente na medida em que comportaria custos elevados para a sociedade de comando, desestimulando a criação de grupos de sociedades. Além disso, um modelo de regulação de grupos não seria capaz de abarcar totalmente um fenômeno tão complexo e maleável como os grupos de sociedades, o que destruiria a flexibilidade do instituto. Desta forma, o aplicador do direito somente interviria

163 ANTUNES, 1994, p. 237. O princípio também é válido para o direito inglês: "The starting point for any discussion in English company law of the legal problems arising from corporate group activitiy is the corporate entity doctrine by which a company on incorporation becomes a legal entity which is separate and distinct from the members who compose it." (PRENTICE, D.D. Groups of Companies: the English Experience. In: HOPT, Klaus J. (Org.). Groups of Companies in European Laws. Berlin: Walter de Gruyter, 1982. v. II, p. 100.)

164 MUNHOZ, 2002, p. 264. No mesmo sentido: “Entity law rigidly governs all legal relationships of a corporation, without regard to whether the corporation is owned and controlled by individual human beings or by another corporation. Althought the concept had been formulated centuries before corporations could acquire the shares of other corporations, entity law was automatically and apparently unthinkingly applied when corporate groups emerged in American law barely a century ago. Thus, entity law prevails even where the corporation is part of a corporate group owned by a parent corporation, and the corporation is one of a number of companies of a group collectively conducing an integrated business under their parent's control." (BLUMBERG, Phillip I. et al. Blumberg on Corporate Groups, Frederick: Aspen, 2007. v. 1, p. 10-3). 
no caso concreto para coibir os abusos que pudessem ser praticados pelos grupos, por meio da utilização dos princípios gerais do direito de sociedades. ${ }^{165}$

O problema deste modelo de regulação é que muitas vezes as regras do direito societário clássico não são suficientes para regular as questões inerentes aos grupos societários. Como sustenta Blumberg:

For many purposes and in many areas, entity law admirably serves the needs and objectives of the law and the social order. In other circumstances, it is so dysfunctional or lead to such unjust results that the law has developed a variety of doctrines supporting the attribution of the legal consequences of the acts of one constituent company of a corporate group to another. This most often takes the form of imposing the obligations or other legal consequences arising from acts of a subsidiary (or controlled corporation) upon its parent corporation (or individual controlling shareholder). However, it may also involve subjecting the subsidiary to legal consequences arising from the acts of its parent corporation or sister subsidiary. ${ }^{166}$

Para os problemas que pudessem surgir das relações entre as sociedades pertencentes a grupos, a principal solução encontrada foi a aplicação da doutrina da desconsideração da personalidade jurídica ${ }^{167}$, de origem jurisprudencial. ${ }^{168,169}$ Contudo, a

165 ARRIBA FERNÁNDEZ, 2004, p. 40-41. A autora menciona que este é também o sistema vigente no direito espanhol. De fato, o artigo 89.3 da lei de sociedades anônimas espanhola determina que "Se reputarán como responsables de la infracción a los administradores de la sociedad infractora y, en su caso, a los de la sociedad dominante que hayan inducido a cometer la infracción. Se considerarán como administradores no sólo a los miembros del Consejo de administración, sino también a los directivos o personas con poder de representación de la sociedad infractora. La responsabilidad se exigirá conforme a los criterios previstos en los artículos 127 y 133 de la presente ley" (grifo nosso).

166 BLUMBERG et al, 2007, p. 10-4.

167 O capítulo seguinte tratará especificamente deste assunto.

168 ANTUNES, 1994, p. 238: “[...] entity law appears to be ultimately responsible for the emergence of a legal doctrine, developed essentially via judicial case-law to solve liability problems raised in the context of parent-subsidiary relationships - the so-called piercing the corporate veil jurisprudence. This doctrine is characterized essentially by bringing intragroup liability issues under a sort of rule-exception approach, that is, the parent corporation is not ordinarily liable for its subsidiary's debts save for exceptional cases where special and unusual circumstances authorize the disregard of the separate corporateness of the two entities.". No mesmo sentido: "Piercing the veil jurisprudence' dominates the common law cases involving the imposition of liability on one affiliate of a corporate group for acts of another affiliate, whether they be contract or tort cases, and is frequently employed in cases involving property rights as well. Although other doctrines play some role in resolving questions of intragroup tort liability, 'piercing the veil' is the traditional approach of the courts to consideration of intragroup liability matters. Under this view, the imposition of liability upon a parent (or other component) of a group for the torts or contracts of a subsidiary (or other affiliate) rests on a disregard of the separate corporate entities of the two corporations. These courts start with the premise that entity law controls and that entity law exists to serve a fundamental principle underlying the corporate system - the principle of 'limited liability'. This leads to the corollary that the disregard of entity (that is, 'piercing the corporate veil') should be approached 'reluctantly' or 'cautiously' and should be undertaken only in 'exceptional' 
aplicação da desconsideração da personalidade jurídica a estes casos é feita em caráter excepcional e de forma extremamente casuística e pouco sistemática, o que gera grande insegurança jurídica. ${ }^{170}$

Essa situação resultou em diversas críticas ao modelo por parte da doutrina norteamericana. Antunes faz detalhada análise das principais críticas ao modelo. ${ }^{171}$ Munhoz, em bela síntese, indica as principais críticas apresentadas.

Primeiramente, destaca que no modelo das sociedades isoladas a limitação da responsabilidade dos acionistas serve para a mobilização da poupança popular. No caso dos grupos de sociedades, a situação é completamente diversa. Neste caso, a limitação da responsabilidade da controladora pelos atos da sociedade controlada pode incentivar o investimento em empreendimentos econômicos de risco elevado, externalizando os custos à comunidade e incentivando a irresponsabilidade empresarial. ${ }^{172}$

cases.” (BLUMBERG, Phillip I. The Law of Corporate Groups - substantive law. London: Little, Brown and Company, 1987, p. 105-106).

${ }^{169}$ Como observa Galgano: "La giurisprudenza dei paesi anglosassoni si atiene ad una significativa massima: la persona giuridica deve essere considerate un soggeto distinto dalle persone fisiche dei suoi membri fino a cuando non sussita un ragionevole motivo per efermare il contrario. Così quei giudici reprimono gli abusi della personalità giuridica e, come là si dice, ne 'perforano lo achermo' o ne 'squarciano il velo': essi, ad esempio, considerano tassabili come beni del socio I beni che questi, per frodare al fisco, abbia intestate ad una società; oppure condannano per violazione di un patto di non concorrenza l'imprenditore che, per eludere il patto, abbia costituito una società e svolga sotto il nome di questa l'attività concorrenziale. Ocorre un 'ragionevole motivo' dicono I giudici di common law; il superamento dello schermo della personalità giuridica à considerato - come deve essere considerato quale rimedio estremo, al quale fare ricorso quando nessun otro rimedio è esperibile per reprimere l'abuso." (GALGANO, 2003, p. 234).

170 "The crucial question that such a principle-exception approach to intragroup liability problems immediately puts is: which are those exceptional cases where disregard may be justified and liability may be imposed on parent corporations? Here we are forced to answer that we are facing a wilderness of principle. Built as they are upon metaphoric, formal and universal standards, the cases in which the courts pierced the corporate veil are devoid of any consistent policy and make it impossible to predict with any degree of accuracy the occasions when courts will disregard the corporateness of group affiliates." (ANTUNES, 1994, p. 241). Ainda: "[T]he piercing cases often turn on a disorganized accumulation of the facts, more circumspectly described as 'the totality of the circumstances'. Courts frequently allude to so-called guidelines for piercing, sometimes enumerating a score of factors to be evaluated. However, these courts simultaneously caution that no one factor is decisive, and thus such factors provide limited guidance for the ultimate decision-making process. In consequence, the rules developed by the courts have confused rathers than clarified the problem. [...] As a result, we are faced with hundreds of decisions that are irreconcilable and not entirely comprehensible." (BLUMBERG et al, 2007, p. 10-6-10-7.). No mesmo sentido, MUNHOZ, 2002, p. 264. No direito inglês, vale a mesma observação: "Although the courts will on occasions pierce the corporate veil and examine the underlying economic and commercial factors, it is impossible to predict with any degree of accuracy when they will do so. The cases in which the courts have pierced the corporate veil are a wilderness of principle and are devoid of any consistent policy." (PRENTICE, 1982, p. 101).

171 ANTUNES, op. cit., p. 259-277.

172 Conforme MUNHOZ, op. cit., p. 265; ANTUNES, op. cit., p. 271. 
Além disso, o grupo pode ser utilizado com a finalidade de exteriorização de riscos, na medida em que uma sociedade pode desmembrar-se em várias unidades produtivas (e juridicamente independentes), isolando os principais ativos em uma sociedade não operacional, protegendo-os assim de seus credores.

Por fim, Munhoz lembra que o princípio da responsabilidade limitada, como dito acima, busca a proteção do público investidor. Nos grupos de sociedade, o investidor é uma única sociedade (ou poucas sociedades) e não a comunidade. ${ }^{173}$ Não faz sentido que o grau de proteção seja o mesmo.

\subsection{O modelo orgânico europeu}

Modelo completamente diferente é o enterprise approach da doutrina européia, também denominado modelo orgânico. Antunes aponta que o princípio fundamental desta corrente é o de que "the parent corporation shall be liable for all the unpaid debts and acts of its subsidiaries for the reason that the former controls the latter forming thereby a unitary economic enterprise." 174 Na contramão do modelo norte-americano, o modelo orgânico prega a responsabilidade ilimitada da controladora do grupo pelas dívidas das sociedades filiadas, na medida em que elas compõem uma unidade empresarial.

A tentativa de sistematização do modelo orgânico, como apontada pelo autor português, vem do projeto de sociedade anônima européia de $1970^{175}$ e do projeto de $9^{\mathrm{a}}$

173 Conforme MUNHOZ, 2002, p. 265-266.

174 ANTUNES, 1994, p. 277.

175 A idéia por trás deste projeto era a elaboração de regras para uma sociedade anônima européia "tipo", de atuação supranacional, que existiria concomitantemente com as sociedades anônimas nacionais européias e que seriam utilizadas por empresas que desejassem desenvolver atividades em toda a Comunidade Européia. A íntima relação entre o propósito original da proposta e o fenômeno da concentração interempresarial explica por que o estatuto da sociedade anônima européia considerava o problema dos grupos de sociedades e incluiu uma regulamentação geral sobre o assunto (Ibid., p. 277-279). O projeto original foi apresentado em 1970, sendo aditado em 1975. Posteriormente, novas versões foram apresentadas em 1989 e 1991, mas nestas duas últimas versões a disciplina própria dos grupos de sociedade foi suprimida. O Estatuto da Sociedade Européia foi aprovado em 8 de outubro de 2001, e entrou em vigor em 8 de outubro de 2004 (Regulamento n 2.157 do Conselho da União Européia), mas a versão aprovada não trata dos grupos de sociedade de forma sistematizada (conforme ANTUNES, op. cit., p. 279; MUNHOZ, op. cit., p. 267; PRADO, 2006, p. 116-117). Em vista disso, os comentários relativos ao modelo orgânico feitos nesta dissertação terão por base os textos de 1970/1975. 
Diretiva da União Européia relativa à harmonização das regras relativas aos grupos de sociedades. ${ }^{176}$

O modelo orgânico pode ser considerado, como dito acima, o extremo oposto do entity approach, "substituindo totalmente o paradigma da sociedade juridicamente autônoma, pelo critério da unidade empresarial." ${ }^{177}$ O ponto de partida do modelo é a própria definição do grupo de sociedade, baseada em dois aspectos fundamentais: a influência dominante e a direção unitária.

O conteúdo destes dois elementos, contudo, é definido no projeto de maneira bastante vaga e genérica. A influência dominante é definida em função do poder de controle exercido pela sociedade de comando sobre as sociedades filiadas, isto é, a relação de controle é definida como a habilidade de uma empresa de exercer uma influência dominante direta ou indiretamente sobre outra. A definição da direção unitária simplesmente não está incluída no projeto e, em vista disso, há um "sistema de presunções" desenhado para facilitar a sua identificação.

A existência de uma direção unitária e, conseqüentemente, de um grupo, é presumida sempre que existir relação de controle entre duas empresas. A existência desta relação, por sua vez, é presunção iuris tantum caso uma das empresas tenha a maioria do capital social da outra, e presunção iuris et de iure caso a primeira: (i) tenha a maioria do capital votante da empresa controlada; ou (ii) esteja em posição de apontar metade dos membros da diretoria e conselho de administração da última; ou (iii) exerça sobre a última influência dominante por meio de contrato ou qualquer outra forma. ${ }^{178}$

Uma vez enquadrada a situação fática na definição contida acima, está configurado o grupo de sociedades. Arriba Fernández indica que, neste modelo de regulação, não importa a origem da direção unitária (contratual, participação em outras sociedades,

176 Este documento era dividido em duas partes, tendo sido a primeira publicada em 1974 e a segunda em 1975. A primeira parte trazia algumas alterações a diretivas anteriores da União Européia com relação a certas definições que se relacionavam aos grupos de sociedades. A segunda parte era a efetiva regulamentação dos grupos de sociedades. Este documento trazia, em realidade, uma compilação das estruturas regulatórias sobre os grupos existentes até então na Europa, composta dos modelos orgânico (contido basicamente no projeto de sociedade anônima européia de 1970 que será analisado nas próximas linhas) e contratual, vigente na Alemanha (que será tratado a seguir, quando da análise do dualist approach). Os modelos eram alternativos, cabendo a cada um dos Estados Membros a definição de qual deles seria adotado pelo legislador nacional. Entretanto, o documento mostrava evidente preferência pelo modelo orgânico (conforme ANTUNES, op. cit., p. 286-287).

177 MUNHOZ, 2002, p. 267.

178 Conforme ANTUNES, 1994, p. 280-281. 
coincidência de membros dos órgãos de administração etc.) nem a forma como o grupo se estrutura. Importa apenas que o grupo preencha os requisitos fáticos legalmente estabelecidos. Desta forma, a aplicação da regulação dos grupos não depende da vontade das partes, mas sim da verificação de uma situação concreta. ${ }^{179}$

Verificada a existência do grupo na realidade fática, aplica-se então a regra de responsabilidade do modelo orgânico, na qual a sociedade dominante possui responsabilidade ilimitada pelos débitos das sociedades dependentes. ${ }^{180}$ Como destaca Munhoz,

[...] não se trata, propriamente, de uma responsabilidade subsidiária, pois não há a necessidade da excussão prévia dos bens da sociedade dependente para a sua configuração. Basta a falta de pagamento do débito pela sociedade dependente e a sua constituição em mora para que o credor possa se voltar contra a sociedade dominante. $^{181}$

Este modelo orgânico recebeu tantas críticas quanto o modelo norte-americano. A primeira delas diz respeito à insegurança. Como a definição dos elementos que caracterizam os grupos de sociedades é bastante vaga, é difícil identificar quais estruturas, no caso concreto, configurarão um grupo de sociedades. Assim,

[...] os agentes econômicos não disporiam de critérios seguros para conhecer previamente a extensão dos riscos assumidos, ou seja, de suas responsabilidades [...]. Nessa linha, a adoção do modelo orgânico não traria maiores benefícios do que aqueles proporcionados pelo modelo clássico [norte-americano] [...]. [N]o sistema orgânico, os tribunais teriam ampla margem de interpretação para decidir os casos concretos, sem que houvesse maior sistematização teórica."182

179 ARRIBA FERNÁNDEZ, 2004 p. 38-39. Vide também comentários sobre este modelo em EMBID IRUJO, 1984b, p. 31-32.

${ }^{180}$ No mesmo sentido, Leonardo de Gouvêa Castellões: "Ante a mera constatação da existência do grupo como unidade econômico-empresarial - constatação que se deve levar a cabo através de um sistema de presunções revelador da ocorrência de influência dominante e de direção unitária - se lhe aplica o regime jurídico específico." (CASTELLÕES, 2008, p. 104).

181 MUNHOZ, 2002, p. 269.

182 Ibid., p. 269. No mesmo sentido, ANTUNES, 1994, p. 296-298. 
Outra crítica apontada é a rigidez do modelo ${ }^{183}$, que pressupõe a aplicação da responsabilidade ilimitada da sociedade controladora pelas dívidas das controladas independente das múltiplas formas de organização e concentração que os grupos possam adotar.

By not distinguishing between potential control and actual control, nor between 'bad' control and 'good' control, the system thus holds parent corporations inescapably liable for all the debts of their subsidiaries, including those debts without any connection with its real control or those issuing from a parent's control which have been undertaken in the best interests of the subsidiary. ${ }^{184}$

Essa rigidez, como indica Munhoz, baseado em Antunes, cria uma desvantagem competitiva para os grupos. Isso porque, mesmo que atuem de forma descentralizada, com manutenção da autonomia das sociedades filiadas, estas sociedades ainda assim seriam entendidas como uma unidade econômica, e acabariam por ter de observar um sistema de responsabilidade mais rigoroso que o das sociedades isoladas. ${ }^{185}$ Isso poderia resultar, em última instância, em um grande desincentivo à utilização da figura dos grupos.

Por fim, Antunes e Munhoz destacam que o modelo orgânico traz também problemas com relação aos sócios e credores das sociedades dominante e dominadas.

$\mathrm{Na}$ medida em que a sociedade dominante tem responsabilidade ilimitada sobre os débitos das sociedades dominadas, os credores da primeira passam a correr os riscos empresariais das últimas, e os sócios minoritários da sociedade dominante podem não ter meios adequados para exercer a adequada fiscalização das atividades das dominadas.

Nas sociedades controladas, os sócios minoritários ficarão ainda mais dependentes da sociedade dominante, na medida em que ela não se sujeitará a nenhuma decisão empresarial relevante das sociedades filiadas de que não tenha participado (pois possui responsabilidade ilimitada). Quanto aos credores das controladas, embora exista a possibilidade de benefício em função da responsabilidade ilimitada da controladora, poderão ser prejudicados pelo esvaziamento do patrimônio da sociedade dependente com a

183 “[...] la gran ventaja de este modelo se convierte en su mayor inconveniente: a saber, su rigidez, dicho de otro modo, su carácter imperativo.” (ARRIBA FERNÁNDEZ, 2004, p. 39).

${ }^{184}$ ANTUNES, 1994, p. 300.

${ }^{185}$ MUNHOZ, 2002, p. 270. 
qual originalmente contrataram caso este patrimônio seja utilizado, por determinação da sociedade dominante, para o pagamento dos débitos de outra sociedade dominada integrante do mesmo grupo. ${ }^{186,187}$

${ }^{186}$ ANTUNES, 1994, p. 306-308; MUNHOZ, 2002, p. 270-271.

187 Ainda com relação às propostas de regulamentação dos grupos nos Estados Membros da União Européia, merece destaque a chamada "Proposta Cousté" de 1970 (proposta de lei sobre regulação dos grupos de sociedades e proteção de acionistas, trabalhadores e credores, que ficou assim conhecida por ter sido enviada para a Assembléia Legislativa da França em 19 de fevereiro de 1970 pelos deputados Cousté e Le Douarec). A Proposta Cousté, em linha com o modelo orgânico então discutido na Europa, definia os grupos por meio dos conceitos de influência dominante e direção unitária. A novidade é a introdução de uma presunção de influência dominante quando uma empresa detivesse $25 \%$ ou mais do capital votante de outra. Não existia definição de direção unitária. As regras de proteção de acionistas, trabalhadores e credores em nenhum momento se referiam à noção de grupo, mas apenas a sociedades "dominantes" e "dominadas". Assim, a mera existência de controle de uma sociedade sobre a outra poderia ser suficiente para que as regras de proteção de acionistas, trabalhadores e credores do grupo pudessem ser aplicadas. Considerando que a mera detenção de $25 \%$ do capital votante de uma empresa era presumido como existência de influência dominante, a doutrina considerou a proposta extremamente severa. Além disso, havia previsão de que a sociedade dominante era solidariamente responsável com a sociedade dominada pelas dívidas, com terceiros, contraídas pela última anteriormente ao final do exercício social anterior e que não houvessem sido pagas em três meses contados da aprovação das contas deste mesmo exercício fiscal. Sociedades dominantes tinham também a obrigação de cobrir as perdas anuais de suas controladas. Em 1974 uma nova versão da proposta, mais flexível, foi apresentada. Os grupos continuavam a ser identificados pelos elementos da influência dominante e da direção unitária, mas a presunção de dependência passou a ser considerada apenas quando uma sociedade detivesse $50 \%$ ou mais do capital votante de outra. Uma terceira proposta foi elaborada em 1977/1978. Esta terceira versão continha uma definição de grupos muito influenciada pela legislação alemã e pelo projeto de estatuto da sociedade anônima européia. Desta forma, haveria grupo de sociedades quando houvesse ligação de dependência entre duas sociedades com administração unitária. Haveria também presunção de formação de grupo entre sociedade controladora e controlada e presunção de dependência quando uma sociedade exerce, direta ou indiretamente, o controle sobre outra. Por fim, havia presunção de dependência quando uma sociedade detivesse 50\% do capital social votante de outra (conforme ANTUNES, op. cit., p. 289-292; PRADO, 2006, p. 119-120). Sobre a Proposta Cousté, vide também HOUIN, Roger. Les Groupes de Sociétés em Droit Français. In: HOPT, Klaus J. (Org.). Groups of companies in European Laws. Berlin: Walter de Gruyer, 1982. v. II, p. 56-57. Também merece destaque a iniciativa do Fórum Europaeum, apontada por Embid Irujo. Segundo este autor, um grupo de estudiosos europeus reuniu-se no chamado Forum Europaeum e apresentou um extenso trabalho cuja finalidade era dotar a figura dos grupos de sociedades de um regime jurídico ponderado, que garantisse um marco seguro e adequado para o funcionamento dos grupos. O Forum Europaeum não apresentou, contudo, um quadro normativo fechado relativo aos grupos de sociedades. Nem era esta a intenção. Os estudiosos limitaram-se a apresentar considerações, diretivas a respeito de algumas questões consideradas fundamentais no âmbito dos grupos: (i) definição; (ii) publicidade; (iii) administração; (iv) controle especial; (v) ofertas públicas de aquisição de ações de caráter obrigatório; (vi) exclusão e direito de recesso dos minoritários; e (vii) responsabilidade nas situações de crise e insolvência do grupo. Não cabe aqui fazer uma análise exaustiva do conteúdo do Forum Europaeum, apenas destacar o esforço para buscar as bases que viabilizariam a determinação de uma série de regras básicas sobre os grupos de sociedades na União Européia. Cumpre destacar também que a iniciativa do Forum Europaeum não teve qualquer incentivo governamental ou comunitário. Como definiu Embid Irulo, "Ante la atonía que, por el momento, muestran las instituciones comunitarias respecto de este tema, corresponde a la Ciencia jurídica europea, ejerciendo la antes indicada autonomía de la voluntad 'intelectual', la tarea de mejorar el importante trabajo del Forum" (EMBID IRULO, 2003, cap.VI). Sobre este assunto, vide também HOPT, Klaus J. Comparative company law. 1 dec. 2006. Disponível em: 〈http://www.ssrn.com/abstract=980981〉. Acesso em: 30 maio 2008, p. 11751176. 
2.2.3.1.3 O modelo dualista alemão

O último modelo de regulação dos grupos a ser analisado é aquele que Antunes denomina dualist approach, de origem alemã (e que alguns autores denominam modelo contratual). Para Antunes, trata-se de uma solução intermediária entre os modelos norteamericano e europeu, e sua principal característica é a distinção entre dois tipos de grupos de sociedades, os grupos contratuais e os grupos de fato, cada qual com um tratamento jurídico distinto.

Os grupos contratuais (também chamados grupos de direito) são aqueles nos quais a direção unitária e a influência exercida pela sociedade dominante são legitimadas pela existência de um contrato firmado entre esta e a(s) sociedade(s) dominada(s), afastando a incidência de alguns dos "cânones da lei societária básica como lei da sociedade isolada". No caso dos grupos de fato, nos quais a direção unitária e a influência exercida pela sociedade dominante é feita sem a existência do contrato mencionado acima, persiste a obrigação de respeitar "os cânones da lei societária tradicional, especialmente o respeito à autonomia e interesse" da sociedade dominada. ${ }^{188}$

O que se verifica, na verdade, é que regras especiais aplicáveis aos grupos de sociedade (que derrogam as regras do direito societário clássico) aplicam-se somente aos grupos contratuais.

Por lo que respecta a este modelo, su característica fundamental consiste en que el régimen jurídico promulgado para los grupos de sociedades sólo entra en escena si el grupo se ha constituido con arreglo a un instrumento jurídico previsto en la propia ley, generalmente un contrato por el que las sociedades contratantes se someten a la dirección unitaria de una de ellas. Sobre la base de este contrato, se legitima el interés del grupo, en definitiva el poder de dirección del grupo, y se autoriza, por tanto, la posibilidad de que las sociedades integrantes del mismo sufran perjuicios en la persecución de dicho interés; perjuicios que deberán ser convenientemente indemnizados o compensados mediante los mecanismos previstos en la legislación especial de grupos. ${ }^{189}$

O regramento dos grupos de sociedades no direito alemão está contido na lei societária de 1965 deste país, embora o diploma societário anterior, de 1937, já contivesse algumas disposições dispersas sobre o tema. Por ser "the most pioneering, elaborated and

188 ANTUNES, 1994, p. 313-314.

189 ARRIBA FERNÁNDEZ, 2004, p. 37. 
complex attemp so far developed at a general regulations of corporate groups”, o regramento alemão influenciou todos os seguintes esforços legislativos de codificação dos grupos, tanto no nível internacional (há influência da lei alemã nas propostas de diretivas européias para harmonização das regras sobre grupos de sociedades) quanto no nível nacional (a legislação alemã serviu de inspiração para outros países que emitiram legislações posteriores sobre grupos de sociedades, tais como Brasil, Portugal e Hungria). ${ }^{190}$

Em linhas gerais, conforme Antunes, a regulamentação sobre os grupos contida na legislação societária alemã pode ser dividida em dois blocos. No primeiro deles, há normas contendo a definição geral das várias formas de ligação de empresas ${ }^{191}$, sendo que, em todas elas, pode haver uma relação de dependência ou uma relação de grupo.

Há dependência econômica sempre que uma empresa, denominada dominante, tem a possibilidade de exercer, direta ou indiretamente, uma influência dominante sobre outra empresa, chamada dominada, sendo essa possibilidade presumida caso a empresa dominante detenha a maioria do capital social da dominada. Já o grupo de sociedades, a forma mais intensa de ligação entre empresas, existe sempre que uma empresa dominante reúna uma ou mais empresas dominadas sob uma direção unitária. ${ }^{192}$

A lei alemã não define o conceito de influência dominante nem o de direção unitária (e, como visto anteriormente, a definição destes conceitos é bastante difícil). A existência do grupo, com base nos critérios descritos acima, é feita com base em presunções, sendo a presunção de existência do grupo iure et de iure em caso de existência de um contrato de dominação firmado entre as empresas ligadas e iure tantum em caso de existência de mera relação de dependência entre as empresas. ${ }^{193}$

190 ANTUNES, 1994, p. 314-317.

191 Viviane Muller Prado ensina que, nos termos da legislação alemã, empresas ligadas são aquelas legalmente independentes que possuem relações com as outras de uma das seguintes naturezas: participação majoritária, dependência e domínio, grupo de empresas (Konzern), participações recíprocas ou vínculos contratuais. Também configuram casos de relação entre empresas a aquisição de todas as ações da sociedade dominada pela dominante (PRADO, 2006, p. 11-112).

192 ANTUNES, op. cit., p. 316.

193 Ibid., p. 316. Cabe transcrever a sistemática explicação de Prado: “A cadeia de presunção é a seguinte: presume-se que na participação majoritária há relação de dependência entre a empresa dominante e a sociedade dependente e, em seguida, pressupõe-se que a relação de dependência configura um grupo empresarial. [...] [A] relação de dependência [...] existe quando, sobre sociedades juridicamente autônomas, pode ser exercida influência dominante, direta ou indiretamente, pela empresa dominante. Em seguida, a lei pressupõe haver relação de dependência quando houver participação majoritária [...]. Posteriormente, [...] estabelece expressamente uma nova presunção de que há grupo de empresas (Konzern) nas hipóteses de dependência, bem como de contrato de domínio e de aquisição de todas as 
O segundo bloco de regras, que a lei alemã trata, consiste no efetivo regramento dos grupos e é dividido em cinco partes.

O primeiro deles trata dos contratos de dominação ${ }^{194}$, "providing substantial regulation on the power of direction of the parent corporation over the subsidiary corporation [...] and the corresponding protective measures for the subsidiary corporation, shareholders and creditors". ${ }^{195}$ A segunda parte trata das situações em que as relações de dependência e de grupo se tratam sem a existência de um contrato de dominação, estabelecendo os limites em que a influência da sociedade dominante sobre a sociedade dependente é permitida, com a obrigação de compensação, pela sociedade dominante, dos prejuízos causados à dependente em razão desta influência. A terceira, quarta e quinta partes, respectivamente, tratam de integração de subsidiárias integrais, participações recíprocas e demonstrações financeiras consolidadas. ${ }^{196}$

Com este panorama regulatório, estabelece-se o sistema dualista alemão, baseado no contraste entre grupos de direito e grupos de fato. Para os grupos de direito, a existência de um contrato de dominação voluntariamente firmado entre as empresas legitima a subordinação de uma ou mais sociedades à sociedade dominante, afastando algumas regras do direito societário clássico aplicáveis às sociedades isoladas e, em contrapartida, estabelecendo determinadas formas de proteção dos interesses de terceiros (minoritários e credores). Para os grupos de fato, permanece a aplicação das regras societárias clássicas

ações pela empresa dominante. Em virtude dessas presunções legais, constata-se que as hipóteses de empresas ligadas previstas no $§ 15$ [da lei de sociedades anônimas alemã] não são excludentes entre si. Em um mesmo caso, pode-se verificar a participação majoritária, que representa a dependência, que por sua vez possibilita a existência de um grupo de empresas. Por outro lado, pode haver relação de dependência sem que se configurem necessariamente grupos de empresas. Esta possível não-coincidência decorre da indispensabilidade da verificação da direção unitária para a configuração dos grupos." (PRADO, op. cit., p. 112-113).

194 E demais contratos de integração empresarial, listados por Eduardo Secchi Munhoz: contrato de dominação, contrato de transferência global de lucros, contrato de comunhão de lucros, contrato de transferência parcial de lucros, contrato de arrendamento de fundo de comércio e contrato de cessão de estabelecimento (MUNHOZ, 2002, p. 274).

195 A proteção a credores e minoritários é bem sintetizada por Munhoz: "Em relação aos minoritários, confere-se o direito à alienação de suas quotas [...], ou o direito a uma garantia de lucros, consistente no recebimento de uma compensação monetária periódica, baseada nos lucros auferidos pela sociedade dependente antes da constituição do grupo e numa previsão de resultados futuros, caso esta se mantivesse como sociedade independente [...]. No tocante aos credores, a lei alemã não estabelece a responsabilidade subsidiária ou solidária da dominante, mas obriga a compensar anualmente qualquer perda eventualmente sofrida pela sociedade dependente [...]." (Ibid., p. 272-275).

196 ANTUNES, 1994, p. 316. O autor salienta que a quinta parte foi substituída por nova regulamentação contina no Código Comercial Alemão em razão de necessária harmonização do direto alemão com Diretivas emanadas da União Européia. Uma análise detalhada destas regras foge ao escopo deste trabalho. 
das sociedades isoladas, devendo a sociedade dominante exercer sua influência no interesse da sociedade dominada, com compensação de eventuais prejuízos causados à última em decorrência do exercício desta influência. ${ }^{197}$

Apesar dos méritos de pioneiramente criar um sistema de regulamentação dos grupos de sociedades, o modelo dualista alemão, assim como o modelo clássico norteamericano e o modelo orgânico europeu, recebeu diversas críticas, todas profundamente debatidas por Antunes. ${ }^{198}$ Dentre as principais críticas, podemos destacar: (i) a não adoção dos grupos contratuais, na medida em que a celebração do contrato de grupo é voluntário e não existe um sistema de sanções para a manutenção de grupos como "de fato" "199; e (ii) a extrema dificuldade - para não dizer impossibilidade - de implementar o sistema de compensação dos prejuízos causados à sociedade dominada em decorrência do exercício da influência da sociedade dominante.

Além disso, Antunes sustenta que o modelo dualista alemão faz uma distinção muito estanque entre grupos de direito e grupos de fato, de forma que os grupos de direito corresponderiam aos grupos centralizados e os grupos de fato corresponderiam aos grupos descentralizados. O problema verificado é que na realidade fática há grupos de direito descentralizados e grupos de fato centralizados. Como conclui Munhoz, com base no texto de Antunes:

Vale dizer, os paradigmas adotados na lei de grupos de direito centralizados e grupos de fato descentralizados, classificados segundo o critério de celebração de um instrumento contratual, não se vinculam às múltiplas formas de organização dos grupos na realidade, deixando sem solução o descompasso entre o direito societário clássico e a realidade, que o modelo contratual objetiva superar. ${ }^{200}$

197 ANTUNES, 1994, p. 320-322. Vide também comentários sobre o modelo contratual em EMBID IRUJO, 1984 b, p. 28-31.

198 ANTUNES, 1994, p. 330-379.

199 Conforme observado também por ARRIBA FERNÁNDEZ, 2004, p. 40.

${ }^{200}$ MUNHOZ, 2002 p. 277. No mesmo sentido, Viviane Muller Prado: "Dentro deste esquema, a classificação dos grupos bifurca-se em grupos contratuais e grupos de fato. Ocorre que a realidade mostrou-se mais rica, exigindo que a doutrina e a jurisprudência refletissem sobre a situação de forte dependência entre empresas, sem o fundamento em um contrato de domínio. Assim, apesar de existirem regras próprias sobre grupos de empresas, há grande influência da jurisprudência no direito grupal. Isso se deve, em especial, à inadequação das regras sobre grupos de fato para a proteção dos minoritários e dos credores. Em linhas gerais, o contrato representa o instrumento jurídico para a formação dos grupos de estrutura centralizada, em que há forte dependência entre a empresa dominante e as dependentes. Nas estruturas das empresas organizadas em grupos, entretanto, constata-se uma riqueza muito maior que o esquema legal, tendo a jurisprudência que analisar situações nas quais, apesar da inexistência de contrato, há o exercício de forte influência da empresa dominante sobre a sociedade dependente [...]”. (PRADO, 2006, p. 121). 
Além das críticas descritas acima, Embid Irujo faz uma crítica genérica aos modelos de regulação dos grupos no direito comparado, especialmente os modelos orgânico e contratual. Para este autor, os modelos existentes pecam por não considerarem os grupos de sociedade como um fenômeno dinâmico. Os grupos de sociedades, na maioria dos casos, não surgem "do nada"; são resultado de um processo de aquisição de participações sociais, pelos mais variados mecanismos (oferta pública de aquisição de ações, cessão de controle, celebração de contratos etc.), que facilitam a integração de uma sociedade à outra.

A obtenção do controle de uma sociedade, por qualquer dos mecanismos descritos acima, e o conseqüente estabelecimento de relação de dependência econômica entre as sociedades não equivale, contudo, a uma situação de grupo, já que não implicam, necessariamente, no exercício de direção unitária. Se não houver direção unitária (ou seja, se não houver relação de grupo), as sociedades dominante e dependente, sem prejuízo de sua vinculação, permanecem independentes e com interesses sociais respectivos, devendo ser aplicadas as regras comuns do direito societário (da sociedade isolada). Quando se instala a direção unitária (e, portanto, o grupo), tem-se uma nova estrutura empresarial, que necessita de regras próprias.

Assim, finaliza Embid Irujo,

[...] empieza a ganar adeptos en la doctrina especializada la idea de que la tipificación jurídica de los grupos de sociedades no debe limitar-se a la consideración exclusiva de éstos, sino que, además, debe incorporar el tratamiento de las técnicas más características de obtención del control de una sociedad y de la situación de dependencia. En ambos casos el tratamiento jurídico aspira a satisfazer las pretensiones de los intereses en presencia, cuidando con especial atención de aquello articulados alrededor de la sociedad cuyo control se obtiene o de la sociedad dependiente. De esta manera en la transición producida desde la sociedad independiente hasta la sociedad integrada en un grupo, el ordenamiento juridico intentará cuidar - de acuerdo con la concepción 'dinámica' del grupo - de los intereses más débiles, incleados alrededor de la sociedad cuyo control se cede, se convierte en sociedad dependiente $y$, porteriormente formajarte de un grupo. Así, se pretende conseguir la salvaguardia de los intereses dignods de tutela a lo largo de todo el proceso que conduce al grupo, sin fiar la protección de los mismos a su consideración exclusiva dentro del grupo, puesto que - como ha mostrado paradigmáticamente la aplicación del Derecho alemán - este planteamiento reduccionista puede conducir a una situación de efectiva desprotección de los intereses que se pretende tutelar. ${ }^{201}$

${ }^{201}$ EMBID IRUJO, 1984b, p. 34-35. A opinião é compartilhada por Herbert Wiedemann: "The law 


\subsubsection{Sistema de regulação dos grupos no direito brasileiro}

As linhas antecedentes procuraram demonstrar um apanhado geral dos principais sistemas de regulação dos grupos de sociedades no direito comparado. Sua intenção era demonstrar as linhas mestras da regulamentação existente no direito comparado, para embasamento da análise do modelo de regulamentação dos grupos de sociedades contidos na LSA.

\subsection{Contexto histórico}

No Brasil, a regulamentação dos grupos de sociedade está contida na LSA, datada de 1976. Em meados da década de 70, o Brasil passava por dificuldades econômicas e políticas que anunciavam o fim do chamado "Milagre Econômico" e ameaçavam o então vigente Regime Militar. Neste contexto, o General Ernesto Geisel assumiu a presidência em março de 1974 e, em seguida, lançou o II Plano Nacional de Desenvolvimento ("II PND").

De acordo com a política da época, apenas por meio da concentração institucional fomentada pelo Estado, as empresas privadas brasileiras poderiam competir em igualdade de condições com as empresas estatais e multinacionais e, assim, o II PND criou um amplo programa de formação de conglomerados financeiro-industrial-comerciais. Embora em franca oposição à tendência mundial de repressão às concentrações empresariais (o Sherman Act e o Clayton Act haviam sido promulgados no final do século XIX), o governo brasileiro considerava a formação de conglomerados fundamental para o revigoramento das atividades empresariais de nosso setor privado $^{202}$.

concerning affiliated companies governs the existing structure of the affiliated enterprises, rather than the process of combine formation. This accounts for the fact that important components of any law concerning the affiliation of the enterprises are not covered by the statute and have been treated by scholars only sporadically. (for example, insider trading, take-over bids, sale of control etc.). Legal control should begin earlier, i.e., already during the formation of the affiliated enterprise, in order, in the interest of the shareholders, creditors and employees, to make penetration by an outside enterprise impossible or at least dependent upon the fulfillment of certain conditions." (WIEDEMANN, Herbert. The German Experience with the Law of Affiliated Enterprises. In: HOPT, Klaus J. (Org.) Groups of Companies in European Laws. Berlin: Walter de Gruyter, 1982. v. II, p. 24.)

202 CARVAlHOSA, Modesto. Comentários à Lei de Sociedades Anônima. 2. ed. São Paulo: Saraiva, 2003, v. 4, tomo II, p. 294. No mesmo sentido: "No direito brasileiro, as concentrações receberam um poderoso 
Como a grande empresa, do ponto de vista jurídico, revestia-se da forma de sociedade por ações, surgiu a necessidade de reforma da lei de sociedades anônimas então vigente, datada de 1940. "A reforma da Lei das Sociedades Anônimas tornava-se imperativa para contemplar a estrutura e o funcionamento da grande empresa privada nacional."203

Com respaldo nestes fundamentos políticos e econômicos, a LSA foi promulgada contendo diversos dispositivos que facilitavam a concentração de empresas e, também, a formação de grupos de sociedades, que eram então considerados um dos principais instrumentos de formação da grande empresa. ${ }^{204}$

O regramento dos grupos de sociedade na LSA, contudo, é bastante simples, pois a intenção era dar bastante liberdade ao empresariado brasileiro para formação de conglomerados. O resultado desta opção política e econômica, como se verá a seguir, é uma disciplina bastante favorável à estrutura organizacional dos grupos e pouca ou nenhuma proteção aos interesses de terceiros, tais como acionistas minoritários e credores. $^{205}$

\subsection{A sistemática da LSA}

O Brasil foi o segundo país do globo a adotar legislação regulamentando os grupos de sociedades, sendo a sua sistemática fortemente inspirada no modelo dualista alemão

estímulo [...]. As razões político-econômicas para isso são claras e se encontram na política de desenvolvimento implantada no Brasil a partir dos anos 60, cuja tradução jurídica ocorre principalmente nos anos 70. Trata-se de uma política claramente orientada no sentido do fortalecimento da grande empresa nacional. Sua expressão máxima está no II Plano Nacional de Desenvolvimento (II PND). Nesse documento faz-se referência explícita à necessidade de fortalecimento da indústria nacional, através da formação de conglomerados para fazer frente à concorrência internacional. [...] Estes princípios foram aplicados ao direito societário na lei acionária brasileira de 1976." (SALOMÃO FILHO, 2002, p. 246247).

203 PRADO, 2006, p. 48.

204 Viviane Muller Prado aponta que o governo brasileiro tomou também outras medidas para facilitar a concentração, retirando impedimentos fiscais para a constituição de holdings. Pela redação do artigo 23 do Decreto-Lei $n^{\circ}$ 1.338/74: "Não estão sujeitos ao desconto do imposto de renda na fonte os lucros, os dividendos, as bonificações em dinheiro e quaisquer outros interesses distribuídos por pessoa jurídica a outra pessoa jurídica, em decorrência de participação societária ou acionária.” (PRADO, 2006, p. 50). Para uma análise detalhada do contexto histórico e do processo de elaboração da LSA, vide LAMY FILHO; PEDREIRA, 1997, p. 117-314. Vide também, no mesmo sentido, CASTELLÕES, 2008, p. 107114.

205 PRADO, op. cit., p. 50-51. 
tratado acima. ${ }^{206}$ Sendo assim, embora com sensíveis diferenças com relação ao modelo alemão, a disciplina dos grupos de sociedades no Brasil é centrada no modelo dualista dos grupos de direito em oposição aos grupos de fato.

A regulamentação dos grupos está contida nos capítulos XX a XXII da LSA. O Capítulo XX trata das sociedades coligadas, controladoras e controladas, constituindo a regulamentação aplicável aos grupos de fato. Os grupos de direito são tratados nos Capítulos XXI e XXII da LSA, que tratam, respectivamente, dos Grupos de Sociedades e dos Consórcios. ${ }^{207}$

Um esclarecimento faz-se necessário. Para o direito brasileiro, os grupos de direito podem ser de coordenação ou de subordinação, sendo a diferença entre eles a não existência, nos grupos de coordenação (também chamados paritários), de relações de controle ou domínio entre as sociedades grupadas. ${ }^{208}$ Grupos de subordinação (de direito) são regulados pelas disposições do Capítulo XXI da LSA, e grupos de coordenação são os consórcios, regulados pelas disposições do Capítulo XXII da LSA. Entretanto, como já demonstrado anteriormente, a análise desta última figura empresarial não faz parte do escopo deste trabalho. Assim, nas linhas seguintes, ao se falar de grupos de direito, entenda-se grupos de direito de subordinação previstos no Capítulo XXI da LSA.

Contrariando a ordem em que as regras estão dispostas na LSA, inicia-se a análise pelos grupos de direito.

$\mathrm{Na}$ LSA, as regras previstas para a regulamentação das sociedades anônimas partem da noção clássica da sociedade isolada. Quando da constituição de um grupo de direito, todavia, estabelece-se um regime específico, aplicável às sociedades grupadas, que derroga algumas das regras aplicáveis às sociedades isoladas e independentes.

O grupo de direito é constituído mediante convenção de grupo firmada entre a sociedade controladora e as sociedades controladas, pela qual tais sociedades se obrigam a "combinar os seus recursos ou esforços para a realização dos respectivos objetivos, ou a participar de atividades ou empreendimentos comuns." (art. 265, caput, LSA). A

${ }^{206}$ Ibid., p. 53; CASTELLÕES, op. cit., p. 107.

207 Viviane Muller Prado: “[...] ressalta-se que a bipartição em grupos de fato e grupos de direito, usualmente utilizada em estudos sobre o tema, não decorre da legislação, mas corresponde à denominação doutrinária, servindo para facilitar o entendimento da sistemática da lei. A Lei das Sociedades por Ações não diferencia expressamente os grupos de fato dos grupos de direito, apenas sugere tal distinção." (PRADO, 2006, p. 53).

208 Ibid., p. 57. 
sociedade $^{209}$ controladora deve ser brasileira ${ }^{210}$ e exercer, direta ou indiretamente e de modo permanente, o controle das sociedades filiadas, sendo que este controle pode ser exercido isoladamente, mediante direitos de sócio ou acionista, ou de forma conjunta, mediante acordo com outros sócios ou acionistas. Nos termos do art. 267 da LSA, somente os grupos de direito, constituídos mediante convenção grupal devidamente levada a registro no Registro do Comércio, podem usar a denominação "grupo" ou "grupos de sociedades". 211

A convenção de grupo deve possuir os requisitos mínimos determinados no art. 269 da LSA. ${ }^{212}$ Em linhas gerais, conforme determina o art. 266 da LSA, a convenção deve estabelecer as relações entre as sociedades, a estrutura de administração do grupo e a coordenação ou subordinação dos administradores das sociedades filiadas. Não obstante, cada uma das sociedades integrantes do grupo mantém personalidade e patrimônio distinto das demais.

Merece destaque a questão da administração dos grupos de direito. Como dito acima, a convenção deve estabelecer a estrutura de administração do grupo e, nos termos do art. 272 da LSA, é permitida inclusive a criação de órgãos de deliberação colegiada e cargos de direção-geral, embora a representação de cada uma das sociedades filiadas possa ser exercida por seus respectivos administradores, exceto se a convenção dispuser de forma diversa.

A partir do momento em que se firma uma convenção grupal determinando o objetivo comum do grupo, as sociedades filiadas estão obrigadas a pautar suas atividades em observância à orientação geral estabelecida na convenção, quer representadas pelos

${ }^{209}$ Como a lei fala expressamente em "sociedades", entende-se que sociedades de quaisquer tipos possam constituir grupos, desde que respeitada a determinação de que a sociedade de comando deve ser brasileira e que estabeleça relações de controle com as sociedades filiadas. Nesse sentido, a legislação brasileira é mais restrita que a alemã, pois a última admite a ligação de formas societárias e não societárias, podendo a empresa dominante ser uma pessoa física, e até mesmo o Estado (conforme PRADO, op. cit., p. 56 e 58; CASTELLÕES, 2008, p. 117). Ainda com relação a este aspecto, vide crítica de FRANCO, Vera Helena de Mello. Particularidades da "Affectio Societatis" no Grupo Econômico. RDM, ano XXXII, n. 89, p. 4755, jan./mar. 1993, p. 47-50.

${ }^{210}$ Respeitando os requisitos determinados no $§$ único do art. 269 da LSA.

${ }^{211}$ Embora a LSA não preveja nenhum tipo de sanção para a violação desta norma (PRADO, 2006, p. 58).

212 São eles: (i) a designação do grupo; (ii) a indicação da sociedade de comando e das filiadas; (iii) as condições de participação das diversas sociedades; (iv) o prazo de duração, se houver, e as condições de extinção; (v) as condições para admissão de outras sociedades e para a retirada das que o componham; (vi) os órgãos e cargos da administração do grupo, suas atribuições e as relações entre a estrutura administrativa do grupo e as das sociedades que o componham; (vii) a declaração da nacionalidade do grupo; e (viii) as condições para alteração da convenção grupal. 
órgãos gerais de administração do grupo, quer por seus próprios administradores. ${ }^{213}$ Isso dá margem à principal característica dos grupos de direito: a legitimação da subordinação do interesse das sociedades filiadas ao interesse do grupo, que pode significar privilegiar o interesse de uma sociedade do grupo em detrimento de outra. ${ }^{214}$ Nos termos do art. 276 da $\mathrm{LSA}^{215}$, é a própria convenção de grupo que determina eventual forma de compensação dos prejuízos causados às sociedades filiadas.

Nesse mesmo sentido, Guerreiro afirmou em artigo publicado em 1983, que "a submissão do interesse da companhia a outro interesse só se admite nos grupos de direito, e nos precisos termos da convenção, que fixam o interesse comum do grupo". 216

Note-se que, apesar de a LSA determinar que a convenção de grupo deva determinar os objetivos comuns do grupo e a sua forma de administração, o direito brasileiro não considera a direção unitária como elemento caracterizador dos grupos de sociedades.

Lembrando que o legislador da LSA tinha um interesse econômico e político em fomentar esta forma de concentração de empresas, como visto anteriormente, há pouca ou nenhuma proteção aos minoritários e credores. Para os minoritários, as duas únicas medidas de proteção são a exigência de quorum qualificado de mais da metade dos sócios ou acionistas com direito a voto para a aprovação da convenção (art. 136, V, combinado com o 270, LSA) e o direito de recesso em caso de dissidência da deliberação de formação do grupo (art. 137, combinado com o 270, § único, LSA). Para os credores, a LSA não prevê nenhum mecanismo de tutela especial. ${ }^{217-218}$

213 Aos administradores da sociedade filiada, ressalvados os deveres e responsabilidades comuns ao exercício do cargo, caberia observar a orientação geral estabelecida pelo grupo, desde que não importe em violação da convenção, enquanto que à sociedade de comando caberia a coordenação e o controle das atividades do grupo (cf. CUNHA, Rodrigo Ferraz Pimenta da. Estrutura de Interesses nas Sociedades Anônimas hierarquia e conflitos. São Paulo: Quartier Latin, 2007, p. 308).

214 Conforme PRADO, 2006, p. 58-59.

215 “Art. 276. A combinação de recursos e esforços, a subordinação dos interesses de uma sociedade aos de outra, ou do grupo, e a participação em custos, receitas ou resultados de atividades ou empreendimentos, somente poderão ser opostos aos sócios minoritários das sociedades filiadas nos termos da convenção de grupo.” Do texto legal, Alfredo Sérgio Lazzareschi Neto depreende que o que não estiver textualmente previsto na convenção de grupo não será oponível aos sócios minoritários das sociedades filiadas (LAZZARESCHI NETO, Alfredo Sérgio. Lei das Sociedades por Ações Anotada. 3. ed. São Paulo: Saraiva, 2010, p. 652).

216 GUERREIRO, 1983, p. 32.

217 Conforme PRADO, 2006, p. 61-62. Sobre o direito de recesso dos minoritários, vide CASTELLÕES, 2008, p. 164-165. Para este autor, guardadas as devidas vênias, as críticas quanto ao fato de ser o direito de recesso a única forma de proteção dos minoritários quando da formação do grupo poderiam ser menos 
Apesar de todo o regramento dos grupos de direito descrito nas linhas anteriores, cumpre destacar que os grupos de direito são figura praticamente inexistente na realidade empresarial brasileira. Para Salomão,

Não é exagerado dizer que o direito grupal brasileiro enfrenta momento de séria crise. Do modelo original praticamente nada resta. Sepultadas pela prática ou pelo legislador, as principais regras conformadoras do direito grupal (grupo de direito) como originalmente idealizado não têm aplicação. Os grupos de direito são letra absolutamente morta na realidade empresarial brasileira, em função sobretudo da inexistência de definição de regras de responsabilidade ${ }^{219}$ e da

rigorosas, uma vez que a decisão sobre a celebração de uma convenção de grupo estaria inteiramente a cargo dos minoritários, já que a sociedade controladora estaria impedida de votar nesta deliberação pela regra de conflito de interesses do art. $115, \S 1^{\circ}$ da LSA.

218 Com relação à (inexistente) proteção aos credores dos grupos, Eduardo Secchi Munhoz sustenta que "Por um lado, os grupos se beneficiam do princípio da limitação da responsabilidade em relação a cada unidade jurídica e, por outro, transferem os riscos ao credor, na medida em que o patrimônio autônomo, que deveria caracterizar cada uma dessas unidades, é inteiramente desvirtuado, não servindo como garantia de cumprimento de obrigações assumidas. Essa situação afeta particularmente os credores dotados de menor poder de negociação (v.g. fornecedores, consumidores, titulares de créditos decorrentes de ilícitos extracontratuais), que não são capazes de exigir garantias da sociedade dominante, como ocorre em relação, por exemplo, às instituições financeiras." (MUNHOZ, 2002, p. 141). No mesmo sentido, Gerard Hertig e Hideki Kanda: "A group structure may adversely affect creditors in two ways. First, such a structure might reduce transparency by blurring divisions between the assets of group members, and by suggesting - often wrongly - that the entire group stands behind each member's debts. Second, a group structure allows controllers to set the terms of intra-group transactions, and thus to assign (and reassign) value within the group. Sometimes an intra-group transaction is designed solely in order to extract value from the creditors or minority shareholders of a group member. More often, however, creditors are injured by transactions that are undertaken for other reasons. For example, the entire group might gain a production, distribution, or tax advantage by shifting assets from one member to another, even though this shift makes the transferor's debt far riskier and thus injuries its creditors (absent explicit guarantees from the other group members).” (KRAAKMAN et al, 2006, p. 75). A explicação para a ausência de regras de proteção aos credores pode ser encontrada na Exposição de Motivos da LSA, a qual dispunha que "[N]o artigo 267, o Projeto absteve-se de criar a responsabilidade solidária presumida das sociedades do mesmo grupo, que continuam a ser patrimônios distintos, como unidades diversas de responsabilidade e risco, pois a experiência mostra que o credor, em geral, obtém a proteção dos seus direitos pela via contratual, e exigirá solidariedade quando o desejar. Ademais, tal solidariedade, se estabelecida em lei, transformaria as sociedades grupadas em departamentos da mesma sociedade, descaracterizando o grupo, na sua natureza de associação de sociedades com personalidade e patrimônio distintos". Neste tocante, COMPARATO dispara: “A explicação é inconvincente no seu todo. [...] [A] prática também ensina sobejamente, que os credores que logram obter garantias complementares aos seus créditos são, em geral, instituições financeiras; raramente os fornecedores, sobretudo de economicamente fracos. São estes, no entanto, que formam a legião dos quirografários desamparados nas falências e concordatas, e são eles que deveriam - em boa justiça - merecer a tutela do legislador. A irresponsabilidade da sociedade de comando grupal, pelas dívidas da controlada, é insustentável na fase hodierna da evolução jurídica" (COMPARATO; SALOMÃO FILHO, 2008, p. 501-502).

219 Isso é notado até mesmo nos doutrinadores de direito comparado, como aponta ANTUNES, 1994, p. 325 : "The Brazilian law [...] develops a group regulation along a set of norms whose basic system can be led back to the distinction between factual and contractual groups, although containing some curious differences from the German model. [...] [A]part from other original features, the group should have its own management organs (distinct from those of the parent) which hold a broad legal power of control over affiliates, in particular a right to issue binding instructions to their management; however, neither the parent nor the group holds any type of direct or indirect responsibility for debts of the group affiliates." 
possibilidade de retirada em massa dos minoritários da sociedade quando da celebração da convenção de grupo. ${ }^{220}$

Prado afirma que como possíveis razões, para a não adoção do grupo convencional, podem-se apontar a artificialidade do modelo importado ${ }^{221}$, a facultatividade de formação de grupos convencionais ${ }^{222}$ e a oneração com o direito de recesso ${ }^{223}$ dos minoritários e com a estrutura administrativa. ${ }^{224}$ Além disso, há grande insegurança jurídica com relação a este instituto, na medida em que sua quase inexistência na vida prática acarreta a existência de poucos estudos nacionais ou jurisprudência sobre o tema. Por fim, o modelo da LSA relativo aos grupos de direito não espelha adequadamente as "necessidades de várias arquiteturas organizacionais, que consideram a sua dinâmica, as estratégias, as peculiaridades de determinados mercados e fatores como o porte, tecnologia, localização e variáveis ambientais'.,225

Pelas razões acima expostas, e conforme já mencionado anteriormente, esta dissertação não dará maior destaque aos grupos de direito, focando sua atenção nos grupos de fato, de que se trata nos parágrafos seguintes.

Com relação aos grupos de fato, regulados no Capítulo XX da LSA, a abordagem é feita a partir do critério do controle societário. Significa dizer que a LSA não disciplina propriamente os grupos societários de fato, mas sim a situação na qual o controle de uma sociedade é exercido por outra sociedade, o que, segundo a doutrina, é o reconhecimento da existência do fenômeno dos grupos de fato. ${ }^{226}$

${ }^{220}$ COMPARATO; SALOMÃO FILHO, 2008, p. 414.

${ }^{221}$ Relacionada à importação parcial do modelo alemão que não tinha qualquer tradição no Brasil e sem a concessão de qualquer benefício econômico.

${ }^{222}$ Cabe à controladora adotar ou não a convenção de grupo. Caso se opte pela não adoção da convenção, não há qualquer penalidade prevista para a manutenção de grupo de fato.

${ }^{223}$ Com o direito de recesso, os acionistas dissidentes da deliberação de formação do grupo podem receber o valor de suas ações ou quotas, o que representa alto custo para a sociedade controladora, semelhante aos custos de realização de operações de fusão ou incorporação. É o que indica Bulhões Pedreira: "Quase todos os grupos existentes no País [...] são sujeitos ao regime do Capítulo XX [da LSA, que regulamenta os chamados grupos de fato], porque a formação de grupo de direito é dificultada pelo direito de retirada dos dissidentes da deliberação da sociedade de integrar o grupo." (PEDREIRA,José Luiz Bulhões. Acordo de acionistas sobre controle de grupo de sociedades. Revista de Direito Bancário, do Mercado de Capitais e da Arbitragem, n. 15, p. 226-248, jan./mar. 2002, p. 244-245.

${ }^{224}$ Não se justifica incorrer em custos para a criação de uma estrutura de administração do grupo se, teoricamente, este resultado pode ser atingido mediante simples participação majoritária nas sociedades controladas.

${ }^{225}$ Conforme PRADO, 2006, p. 70-74.

${ }^{226}$ Conforme PRADO, 2006, p. 137. 
Ao tratar das sociedades coligadas, controladoras e controladas, a LSA prevê três formas de ligação entre empresas: controle, coligação e controle total. ${ }^{227}$

O controle de uma sociedade por outra está definido no art. $243, \S 2^{\circ}$ da LSA:

Considera-se controlada a sociedade na qual a controladora, diretamente ou através de outras controladas, é titular de direitos de sócio que lhe assegurem, de modo permanente, preponderância nas deliberações sociais e o poder de eleger a maioria dos administradores.

Esta definição de sociedade controladora corresponde ao conceito de acionista controlador do art. 116 da LSA, com as adaptações necessárias para compreender todas as formas de controle societário, direto ou indireto (o que inclui as hipóteses de grupo sob controle comum). Importante destacar que, para o caso de sociedades controladoras, não existe o requisito do efetivo exercício do poder para dirigir as atividades das sociedades controladas, pois isso se presume nas relações intersocietárias. ${ }^{228}$

O conceito de coligação de empresas, recentemente alterado pela Lei $n^{\circ}$ $11.941 / 2009$, está previsto nos $\S \S 1^{\circ}, 4^{\circ}$ e $5^{\circ}$ da LSA. Assim, são coligadas as sociedades nas quais a investidora tenha influência significativa, considerando-se influência significativa a hipótese na qual a sociedade investidora detém ou exerce o poder de participar nas decisões das políticas financeira ou operacional da investida, sem controlála. A influência significativa é presumida quando a investidora detém $20 \%$ ou mais do

capital social da sociedade investida, sem controlá-la. ${ }^{229}$

227 Ibid., p 137-138.

${ }^{228}$ Conforme LAZZARESCHI NETO, 2010, p. 593-594.

229 "A influência significativa exclui a existência de controle: em havendo controle, não há que se falar em influência significativa. A lei emprega a expressão 'detém ou exerce'. Com isso, a primeira questão que se põe é se a lei exige que a investidora exerça efetivamente a sua influência sobre a investida, ou se basta que detenha a mera possibilidade de exercê-la. Parece não haver dúvida que é suficiente a mera possibilidade do exercício da influência significativa, porque a lei emprega os termos 'detém ou exerce'; de modo que, se a investidora não o exerce, mas apenas detém a possibilidade de exercício, configurada está a hipótese legal. O que interessa para a lei é a possibilidade de participar das decisões da política financeira ou operacional da investida, parecendo que o legislador quis ser o mais abrangente possível. Assim, por exemplo, se a investidora detém participação societária capaz de eleger um membro do conselho de administração da investida, há influência significativa, porquanto a investidora tem a possibilidade de participar (via conselheiro) das decisões da política financeira ou operacional da coligada, prevaleça ou não o voto do conselheiro eleito pela investidora. O poder de veto (sem controle) 
Por fim, a última hipótese prevista na LSA para ligação entre sociedades é o controle total, corporificado na figura da subsidiária integral (art. 251 da LSA).

Estabelecidas as possibilidades de ligação entre sociedades, o Capítulo XX da LSA trata do regramento jurídico a ser dispensado a tais sociedades em relação de controle e coligação. O princípio fundamental do regramento aplicável aos grupos de fato, que o difere substancialmente do regramento aplicável aos grupos de direito, é o de que exceto para algumas regras específicas aplicáveis às sociedades ligadas ${ }^{230}$, "as sociedades que formam um grupo de fato devem observar a disciplina incidente para as sociedades isoladas". Significa dizer que, nos grupos de fato, não pode haver submissão do interesse de uma sociedade aos interesses de outra sociedade ou do grupo. Essa regra, em princípio, inviabiliza o funcionamento das sociedades integrantes do grupo em conjunto, formando uma unidade econômica. ${ }^{231}$

Esta proteção à individualidade e interesse das sociedades grupadas é bem evidenciada pelas regras de responsabilidade dos administradores e sociedades controladoras previstas nos arts. 245 e 246 da LSA. Pelo art. 245, “Os administradores não podem, em prejuízo da companhia, favorecer sociedade coligada, controladora ou controlada, cumprindo-lhes zelar para que as operações entre as sociedades, se houver, observem condições estritamente comutativas, ou com o pagamento compensatório adequado; e respondem perante a companhia pelas perdas e danos resultantes de atos praticados com infração ao disposto neste artigo". Pelo art. 246, "A sociedade controladora será obrigada a reparar os danos que causar à companhia por atos praticados com infração ao disposto nos arts. 116 e 117" (que tratam de conflito de interesses e abuso de poder de controle).

O modelo proposto para os grupos de fato, assim como o modelo dos grupos de direito, é objeto de críticas da doutrina.

no tocante a certas matérias também caracteriza a influência significativa.” (LAZZARESCHI NETO, 2010, p. 595).

${ }^{230}$ São elas: (i) as regras sobre relatório da administração e demonstrações financeiras dos arts. 243 e $247-$ 250; (ii) as regras sobre responsabilidade dos administradores do art. 245; (iii) as regras sobre participações recíprocas do art. 244; (iv) as regras de reparação de danos causados pela controladora à controlada do art. 246; (v) as regras sobre constituição e funcionamento da subsidiária integral dos arts. 251 e seguintes; (vi) as regras sobre alienação de controle dos arts. 254 e seguintes; e (vii) as regras sobre incorporação de companhia controlada do art. 264, todos da LSA.

231 PRADO, 2006, p. 55-56. 
O direito brasileiro trata os grupos de fato por meio da regulamentação do poder de controle exercido pela controladora sobre as controladas, sem levar em consideração a unidade econômica que comumente se estabelece entre as sociedades ligadas em um grupo de fato.

Munhoz explicita com clareza os principais argumentos da ineficácia da regulamentação dos grupos de fato no Brasil:

\begin{abstract}
A lei parte da ilusória independência das sociedades, classificando como ilícita a eventual subordinação de interesses, quando se demonstrou, porém, que esta subordinação tem natureza estrutural, constituindo elemento integrante da própria função econômica dos grupos. A lei é, portanto, sistematicamente descumprida, sendo os remédios judiciais (ação de reparação por ato abusivo de controle - art. 246; e ação anulatória de deliberação viciada por conflito de interesses - art. 115, $\S 4^{\circ}$ ) incapazes de debelar esta situação. [...] Contribui, ainda, para a ineficácia do sistema, a dificuldade em comprovar o ato abusivo de controle, dada a complexidade dos sistemas de transferência de recursos entre as sociedades. [...] Ademais, a Lei n. 6.404/1976 não previu em relação aos ditos grupos de fato nenhum mecanismo de monitoração ou de fiscalização, direta ou indireta, para os sócios minoritários, da sociedade controladora ou das controladas, em relação às demais sociedades do grupo. [...] No que respeita aos credores das sociedades controladas, o Capítulo XX da lei acionária brasileira não estabelece nenhum mecanismo especial de proteção, na medida em que parte da presunção de que as sociedades integrantes do grupo constituem unidades jurídicas e econômicas autônomas. Nem mesmo para a ação de reparação de danos por atos de abuso de controle, prevista no art. 246 , os credores tiveram reconhecida sua legitimidade, como se não pudessem sofrer prejuízos em decorrência desses atos. ${ }^{232}$
\end{abstract}

Este capítulo tratou do conceito e das principais características dos grupos de sociedades. Como visto acima, embora louváveis os esforços da doutrina em conceituar e sistematizar o fenômeno, há ainda diversas lacunas e questões não resolvidas, especialmente no que diz respeito à adequada conceituação dos grupos e à proteção de credores e acionistas minoritários das sociedades dele integrantes.

Em razão destas lacunas, os operadores do direito buscam alternativas para lidar com os problemas encontrados no caso concreto, e a desconsideração da personalidade jurídica das sociedades integrantes de grupos societários tem sido uma das alternativas mais empregadas. Desta forma, passa-se a uma breve análise, no capítulo seguinte, da

${ }^{232}$ MunHOZ, 2002, p. 279-282. 
desconsideração da personalidade jurídica, para depois estudar sua aplicação aos grupos de sociedades. 


\section{CAPÍTULO 3}

\section{DESCONSIDERAÇÃO DA PERSONALIDADE JURÍDICA}

\subsection{Primórdios}

\subsubsection{A origem jurisprudencial da desconsideração da personalidade jurídica}

Costuma-se apontar o caso Bank of United States vs. Deveaux como o leading case da aplicação da teoria da desconsideração da personalidade jurídica. Neste caso, a discussão centrava-se na competência das Cortes Federais norte-americanas para julgar uma ação em face de um dispositivo da Constituição Federal deste mesmo país que determinava que as Cortes Federais somente pudessem julgar controvérsias entre cidadãos de diferentes estados.

O Chief Justice Marshall decidiu o caso com o intuito de preservar a competência das Cortes Federais para as duas companhias envolvidas na disputa, e para isso teve de "olhar através da sociedade para as características dos indivíduos que a compunham". A Suprema Corte Norte-Americana decidiu que, na essência, as partes da ação eram os sócios e que suas diversas cidadanias (estaduais) deveriam ser consideradas. ${ }^{1}$

Muito embora Nunes e Bianqui destaquem o fato de que a desconsideração da personalidade jurídica foi invocada no caso Bank of United States vs. Deveaux em uma discussão sobre competência e não de utilização da pessoa jurídica como anteparo aos sócios da sociedade, os referidos autores indicam que dela seguiram-se uma série de

1 NUNES, Simone Lahorgue; BIANQUI, Pedro Henrique Torres. A Desconsideração da Personalidade Jurídica: Considerações sobre a Origem do Princípio, sua Positivação e a Aplicação no Brasil. In: FRANÇA, Erasmo Valladão de Azevedo e Novaes (Coord.). Direito Societário Contemporâneo I, São Paulo: Quatier Latin, 2009. p. 299-328, p. 301-302. No mesmo sentido, NUNES, Márcio Tadeu Guimarães. Desconstruindo a Desconsideração da Personalidade Jurídica. São Paulo: Quartier Latin, 2007, p. 89. 
decisões que responsabilizavam pessoas que agiam por intermédio de sociedades, especialmente seus sócios, com a finalidade de prejudicar terceiros (mormente credores). ${ }^{2}$

Outros autores, como é o caso de Requião, apontam o famoso caso Salomon vs. Salomon, julgado em Londres, como o primeiro caso em que a teoria da desconsideração da personalidade jurídica foi utilizada. ${ }^{3}$

Neste caso, o comerciante Aaron Salomon constituiu uma sociedade juntamente com outras seis pessoas de sua família e transferiu à nova sociedade seu fundo de comércio. Em contrapartida, recebeu da nova sociedade a quase totalidade das ações representativas do capital social da companhia, além de obrigações garantidas. Quando a sociedade entrou em liquidação, seus ativos não eram suficientes para o pagamento das obrigações garantidas e, desta forma, não sobrariam bens ou ativos para o pagamento dos credores quirografários. Estes sustentaram, então, que a sociedade era ainda a atividade pessoal exercida por Aaron Salomon, criada apenas com a intenção de limitar a sua própria responsabilidade. ${ }^{4}$

Não obstante a decisão final, do caso, ter sido favorável a Aaron Salomon ${ }^{5-6}$, a técnica da desconsideração da personalidade jurídica alcançou grande sucesso nos tribunais

NUNES; BIANQUI, 2009, p. 301-302.

Suzy Elizabeth Cavalcante Koury, assim como Nunes e Bianqui, sustenta que o caso Salomon vs. Salomon foi julgado 88 anos após o caso americano de 1809 mencionado acima, e que por isso a afirmação de que o caso inglês seria o leading case da desconsideração da personalidade jurídica seria uma inverdade. Para a autora, o caso Salomon vs. Salomon pode ser considerado um leading case apenas para o direito inglês (KOURY, 1998, p. 64).

4 "O comerciante Aaron Salomon, havia constituído uma 'Company', em conjunto com outros seis componentes de sua família, cedido o seu fundo de comércio à sociedade assim formada, recebendo 20.000 ações representativas de sua contribuição ao capital, enquanto para cada um dos outros membros foi distribuída uma ação apenas; para a integralização do valor do aporte efetuado, Salomon recebeu ainda obrigações garantidas de dez mil libras esterlinas. A companhia logo em seguida começou a atrasar os pagamentos, e um ano após, entrando em liquidação, verificou-se que seus bens eram insuficientes para satisfazer as obrigações garantidas, sem que nada sobrasse para os credores quirografários. O liquidante, no interesse desses últimos credores sem garantia, sustentou que a atividade da 'company' era ainda a atividade pessoal de Salomon para limitar a própria responsabilidade; em consequiência, Aaron Salomon deveria ser condenado aos débitos da 'company', vindo o pagamento de seu crédito após a satisfação dos demais credores quirografários. O magistrado que conheceu o caso em primeira instância, secundado depois pela Corte de Apelação, acolhe esta solicitação, julgando que a 'company' era exatamente apenas uma fiduciária de Salomon, ou melhor, um seu 'agent' ou 'trustee', que permanecera, na verdade, o efetivo proprietário do fundo de comércio." (REQUIÃO, Rubens. Abuso de Direito e Fraude Através da Personalidade Jurídica. $R T$, n. 410, p. 12-24, dez. 1969, p. 18).

5 "'.... A Casa dos Lordes acolheu o recurso de Aaron Salomon, para reformar aquele entendimento das instâncias inferiores, na consideração de que a 'company' tinha sido validamente constituída, pois a lei simplesmente requeria a participação de 7 pessoas, que no caso não haviam perseguido nenhum intuito fraudulento. Esses acionistas, segundo os 'Lords', haviam dado vida a um sujeito diverso de si mesmos, e em última análise não podia julgar-se que a 'company' fosse um 'agent' de Salomon. Em consequiência, não existia responsabilidade de Salomon para a 'company' e seus credores e era, conseqüentemente, válido seu crédito privilegiado.” (REQUIÃO, 1969, p. 18). 
norte-americanos, tornando a doutrina muito mais uma construção jurisprudencial norteamericana que britânica. ${ }^{7}$

No direito europeu, Nunes e Bianqui indicam como o leading case uma decisão de 1920 do Tribunal Supremo Alemão, que entendeu que o sócio de uma sociedade unipessoal poderia ser responsabilizado. O tribunal entendeu que "o juiz deve dar mais valor ao poder dos fatos e à realidade da vida do que à construção jurídica". ${ }^{8}$

\subsubsection{Brevíssima notícia sobre estudos para sistematização da teoria no direito comparado}

Foge ao escopo deste trabalho fazer uma análise detalhada dos estudos sobre a desconsideração da personalidade jurídica no direito comparado. Não obstante, apresentam-se abaixo breves notas sobre os esforços da doutrina estrangeira para a sistematização da teoria, na medida em que tais estudos influenciaram a doutrina brasileira sobre o tema, da qual trataremos no item a seguir.

Como dito acima, foi nos Estados Unidos que a teoria da desconsideração da personalidade jurídica desenvolveu-se com vulto nos tribunais. Em vista disso, diversas doutrinas surgiram para explicar o instituto, como ensina Blumberg, mas sempre com base na jurisprudência. ${ }^{9}$

Vide também NUNES, 2007, p. 90-91.

REQUIÃO, 1969, p. 18.

NUNES; BIANQUI, 2009, p. 302.

Blumberg indica que a regra primordial com relação à desconsideração da personalidade jurídica na jurisprudência norte-americana é baseada nas chamadas "jurisprudência clássica de três fatores" e na "jurisprudência de alter ego". Para o autor, "although the two doctrines are expressed differently, they involve the same elements and are interchangeable. They rest on three essential factors: 1. Lack of independent existence of the subsidiary, arising from lack of real-world existence, disregard of corporate forms and formalities, or from excessive exercise of control. 2. Abuse of the corporate form to accomplish fraudulent, inequitable, or wrongful purpose. 3. Causal relationship to the plaintiff's loss." (BLUMBERG et al, 2007, p. 10-8). Apesar de essas teorias serem as dominantes na jurisprudência norteamericana, Blumberg indica a existência de outras teorias, as quais chama de single-factor piercing doctrines. Nestes casos, "instead of dismissing piercing cases in which one of the essential three factors required for traditional piercing has not been established, courts using these doctrines disregard corporate identities and attribute legal consequences of one group affiliate to another. They typically do so in reliance on a particularly egregious demonstration of just a single factor." Este "único fator", geralmente, é a evidência de que a empresa controlada não existe de fato como entidade separada ou a 
No que diz respeito à doutrina, especialmente européia, Salomão apresenta bela síntese sobre as teorias mais importantes a respeito da desconsideração da personalidade jurídica. ${ }^{10}$

Para este autor, apesar de Biagivi ${ }^{11}$ ter sido o primeiro a tratar do tema na doutrina, as principais teorias desenvolvidas sobre a desconsideração da personalidade jurídica

existência de uma subsidiária que é utilizada com propósitos fraudulentos (p. 10-8-10-10). Além das doutrinas descritas acima, Blumberg também destaca outra família de doutrinas que tratam da desconsideração da personalidade jurídica sem qualquer referência às doutrinas indicadas anteriormente. "These doctrines attribute legal rights and duties to the corporate enterprise and its componentes without regard to entity law, focusing instead on the common business, control, and extensive integration of operations and management of the enterprise. They include: (1) the 'single integrated enterprise' doctrine developed in Texas and Lousiana; (2) the intragroup 'descentralization and delegation' doctrine developed in New York for use in determining amenability of jurisdiction (in New York it is know as the 'agency doctrine'); (3) the 'fragmentation of enterprise' doctrine adopted by the Court of Appeals of the Seventh Circuit, which has drawn wide, if scattered, support throughout the country; and (4) the 'integrated enterprise' doctrine developed by the National Labor Relations Board for purposes of the labor acts and widely applied by most courts (excluding the Court of Appeals of the Seventh Circuit) for contruction and application of the labor relations, employment, and antidiscrimination statutes generally.” (p. 10-10-10-11). No primeiro caso, cortes do Texas e da Louisiana trataram sociedades fortemente relacionadas desenvolvendo conjuntamente uma única atividade produtiva como uma única entidade jurídica para fins jurisprudenciais. Apesar desta doutrina não ser comumente referida como uma forma de desconsideração, a Suprema Corte do Texas expressamente a reconheceu como uma variante da jurisprudência da desconsideração, conforme indica o autor. No segundo caso, a jurisprudência entende que quando uma subsidiaria desempenha uma atividade essencial nos negócios do grupo que, de outro modo, deveria ser desenvolvida por sua sociedade controladora localizada em outro estado, a controladora deverá sujeitar-se à jurisdição do estado onde se localiza a controlada. O terceiro caso seria um tema recorrente em algumas jurisdições, que relutam em reconhecer a separação das sociedades que, em vista de excessivas subdivisões da empresa em diversos estados, podem de alguma forma evitar a submissão a várias jurisdições e aparentar esforço de evitar responsabilidades em outros estados. Por fim, o último caso trata de decisões onde a entidade econômica sob controle comum como entidade jurídica responsável pelo propósito em questão (sendo que estes casos são mais comuns em casos de direito antitruste) (p. 10-10-10-13). Para outras doutrinas menos relevantes no direito norte-americano, vide páginas 10-13 a 10-17 da obra acima referida.

10 SALOMÃO FILHO, 2006, p. 208-247.

11 Calixto Salomão Filho aponta que o primeiro a tratar do tema na doutrina foi W. Biagivi, em sua obra L'imprenditore occulto. Segundo Salomão Filho, a teoria de W. Biagivi é centrada na figura do "sócio tirano", que faz uso da sociedade como "coisa própria". "O autor chega à responsabilidade ilimitada do sócio tirano através de sua equiparação à figura do empresário oculto, para o qual já havia deduzido uma regra de responsabilidade pessoal. Essa equiparação é feita com base no domínio por ele exercitado sobre a sociedade, domínio qualificado, verdadeira tirania, segundo o autor, que o transforma em empresário indireto. A este ponto parece já estar claro que o modelo típico de tirania, o sócio único, deve ser invocado para sustentar a teoria. Com efeito, o artigo 2.362 do Codice Civile italiano, que prevê a responsabilidade ilimitada do sócio único, é visto como uma confirmação do princípio da responsabilidade ilimitada do sócio tirano, a ponto de o legislador criar uma presunção iures et de iure de tirania. A desconsideração da personalidade jurídica que essa teoria implica é bastante evidente, ainda que assim não seja qualificada expressamente. Atualmente, é pequeno o seu reconhecimento jurisprudencial, tendo em vista a interpretação restritiva que vem sendo dada ao art. 2.362 do Codice Civile.”. Em nota de rodapé, Salomão indica que Francesco Galgano criticou a confusão da teoria de W. Biagivi com a da desconsideração, porque a primeira não parte de uma discussão crítica do conceito de pessoa jurídica com seus requisitos e pressupostos de aplicação. Entretanto, Salomão cita também a opinião de S. ScottiCamuzzi, segundo o qual a própria teoria de Galgano nada mais é que a transferência e oportuna transformação, para o plano societário, da teoria que Biagivi havia mantido no plano da empresa. (SALOMÃO FILHO, 2006, p. 210). 
podem ser reunidas em duas correntes: a teoria unitarista e a teoria dos centros de imputação.

O principal representante da teoria unitarista é o alemão Serick, responsável pela primeira tentativa de sistematização da teoria da desconsideração da personalidade jurídica com base na jurisprudência alemã e norte-americana, em meados da década de $50^{12}$.

Serick adota um conceito unitário de desconsideração, "ligado a uma visão unitária da pessoa jurídica como ente dotado de uma essência pré-juridica que se contrapõe e, eventualmente, se sobrepõe ao valor específico de cada norma" ${ }^{13}$ Assim, a desconsideração seria um conceito técnico específico, contraposto e excepcional com relação ao princípio da separação patrimonial. Em outras palavras, a personalidade jurídica seria a regra e a desconsideração a exceção, existindo duas hipóteses básicas que possibilitariam a desconsideração da pessoa jurídica: a fraude ou a necessidade de se imputar responsabilidade a um determinado sócio, em função da aplicação de uma lei. ${ }^{14}$

Embora tenha méritos por ser o primeiro sistematizador da teoria da desconsideração da personalidade jurídica, sua obra recebeu diversas críticas por dar tratamento único aos diversos tipos de pessoas jurídicas, mesmo às sociedades unipessoais. $^{15}$

Salomão sustenta que dentro das teorias unitaristas há duas correntes principais. $\mathrm{Na}$ primeira delas, na qual se inclui o próprio Serick, a desconsideração seria justificada pelo "elemento intencional na utilização fraudulenta da forma societária"16. Para a segunda corrente, a desconsideração justificar-se-ia "de um ponto de vista objetivo institucional,

12 Em sua tese de doutoramento apresentada na Universidade de Tübingen em 1952/1953, publicada em 1955 sob o nome Rechtform und Realität Juristicher Personen, conforme OLIVEIRA, J. Lamartine Corrêa de. A dupla crise da pessoa jurídica. São Paulo: Saraiva, 1979, p. 296-297; NUNES; BIANQUI, 2009, p. 303.

13 SALOMÃO FILHO, op. cit., p. 210.

14 NUNES; BIANQUI, op. cit., p. 304.

15 Conforme SALOMÃO FILHO, 2006, p. 211; NUNES; BIANQUI, 2009, p. 306.

16 Além de Rolf Serick, Salomão Filho aponta como principais representantes desta corrente Ulrich Drobnig e o Francesco Galgano. Com relação a Galgano, contudo, Salomão indica que este autor criticou fortemente a teoria unitarista de Serick, mas chegou a resultados muito próximos dela. Para Galgano, segundo Salomão Filho, o "tipo de raciocínio regra/exceção, sem uma conveniente crítica do conceito de pessoa jurídica, levaria a admitir a desconsideração com base em princípios vagos e de difícil determinação como os de eqüidade e justiça". Contudo, Galgano reduz o conteúdo normativo do conceito de pessoa jurídica à responsabilidade limitada de seus membros e, desta forma, a desconsideração só seria possível em caso de abuso e para atribuição de responsabilidade a um sujeito diferente do devedor. "Conseqüentemente, mesmo partindo de pressupostos diversos, chega a resultados muito semelhantes aos da teoria por ele criticada." (SALOMÃO FILHO, op. cit., p. 211-213). 
utilizando critérios não sempre de fácil determinação", tais como utilização contrária de estatutos, à função ou objetivos da pessoa jurídica. ${ }^{17}$

A teoria dos centros de imputação, segundo ensina Salomão, surgiu com o trabalho de Müller-Freienfels. Para este autor, a personalidade jurídica e sua desconsideração não podem ser vistas como um fenômeno unitário, como sustentava Serick. O respeito à separação patrimonial entre a sociedade e seus membros dependeria da análise do caso concreto e da intenção do legislador na determinação de uma dada disciplina legal.

Desta forma, o posicionamento de Müller-Freienfels permite:

[...] uma visão menos rígida da desconsideração, que passa a incluir não apenas as situações de fraude, mas, também, quando necessário, situações em que, à luz da importância e do objetivo da norma aplicável, é conveniente não levar em conta a personalidade jurídica. A desconsideração não é portanto apenas uma reação a comportamentos fraudulentos, mas também uma técnica legislativa ou uma técnica de aplicação de normas [...] que permite dar valor diferenciado aos diversos conjuntos normativos. ${ }^{18}$

A teoria de Müller-Freienfels também considera a avaliação diferenciada dos diversos tipos de sociedade quando da aplicação da teoria da desconsideração da personalidade jurídica, dependendo da função econômica que representam. ${ }^{19}$

Salomão Filho indica que a teoria de Müller-Freienfels pode ser considerada dominante na Alemanha, com grande aceitação na doutrina e na jurisprudência, embora alguns autores discutam se sua teoria pode ser classificada propriamente como uma teoria sobre a desconsideração da personalidade jurídica. Para estes, deveria haver uma distinção entre problemas de mera aplicação das normas existentes no direito civil e problemas de

17 Salomão Filho indica como representante desta corrente Ulrich Immenga (conforme SALOMÃO FILHO, op. cit., p. 211).

18 Ibid., p. 217.

19 SALOMÃO FILHO, 2006, p. 217-219. Para uma análise mais detalhada das obras de Rolf Serick, Ulrich Drobnig e Wolfram Müller-Freienfels, vide OLIVEIRA, 1979, p. 296-368. Vide também as sínteses de BARROS, Cecília Vidigal Monteiro de. A responsabilidade da sociedade controladora pelas dívidas da sociedade controlada nos grupos de sociedades no direito brasileiro e alemão. 1992. Dissertação (Mestrado) - Faculdade de Direito, Universidade de São Paulo, São Paulo, 1992, p. 135-149; NUNES; BIANQUI, 2009, p. 303-307. 
desconsideração da personalidade jurídica em sentido próprio, para cuja caracterização o princípio da separação patrimonial deve ser atingido de uma forma ou de outra. ${ }^{20}$

\subsection{A desconsideração da personalidade jurídica na doutrina brasileira}

Feitas as considerações acima sobre os esforços da doutrina estrangeira para uma sistematização da desconsideração da personalidade jurídica, passa-se a analisar as principais contribuições para a admissão da teoria pelo direito pátrio. Sendo assim, as páginas seguintes tratarão, de forma breve, das três principais obras que contribuíram para o estudo da desconsideração da personalidade jurídica na doutrina nacional.

\subsubsection{O artigo de Rubens Requião}

No Brasil, pode-se dizer que foi Requião o introdutor do conceito da desconsideração da personalidade jurídica no ordenamento pátrio, no já mencionado artigo publicado em 1969. Nele, o autor questiona o absolutismo do direito da personalidade jurídica:

Se a personalidade jurídica constitui uma criação de lei, como concessão do Estado, objetivando, como diz Cunha Gonçalves, 'a realização de um fim', nada mais procedente do que se reconhecer ao Estado, através de sua justiça, a faculdade de verificar se o direito concedido está sendo adequadamente usado. A personalidade jurídica passa a ser considerada doutrinariamente um direito relativo, permitindo ao juiz penetrar o véu da personalidade para coibir os abusos ou condenar a fraude, através de seu uso. ${ }^{21}$

Fortemente inspirado pelos estudos de direito comparado sobre o tema, especialmente a obra de Serick, Requião sustenta que a teoria da desconsideração da personalidade jurídica seria um mecanismo para coibir os casos em que a personalidade

20 SALOMÃO FILHO, op. cit., p. 218.

21 REQUIÃO, 1969, p. 15. 
jurídica (e a conseqüente separação patrimonial que ela proporciona) é utilizada com abuso de direito ou com fraude à lei:

Com efeito, o que se pretende com a doutrina do 'disregard' não é a anulação da personalidade jurídica em toda a sua extensão, mas apenas a declaração de sua ineficácia para determinado efeito, em caso concreto, em virtude de o uso legítimo da personalidade ter sido desviado de sua legítima finalidade (abuso de direito) ou para prejudicar credores ou violar a lei (fraude) [...]. Com isto no fundo não se nega a existência da pessoa, senão que se a preserva na forma com que o ordenamento jurídico a tem concebido. ${ }^{22}$

Adotando o mesmo raciocínio Serick, de que a personalidade jurídica seria a regra e a desconsideração a exceção ${ }^{23}$, Requião conclui em seu mencionado artigo que a teoria da desconsideração da personalidade jurídica é perfeitamente compatível com as regras e princípios do ordenamento brasileiro, chegando a citar casos da jurisprudência brasileira em que o princípio foi aplicado, ainda que sem qualquer menção expressa à teoria. ${ }^{24}$

\subsubsection{Fábio Konder Comparato e o poder de controle}

Posição distinta (e de unitarismo menos evidente, na opinião de Salomão ${ }^{25}$ ) foi adotada por Comparato, que abordou a questão da desconsideração da personalidade jurídica sob o aspecto do poder de controle societário.

Para este autor, embora uma grande parte da doutrina e da jurisprudência tenha procurado justificar a desconsideração da personalidade jurídica com as noções de abuso de direito e de fraude à lei, estes conceitos não englobam todas as possibilidades de aplicação da teoria. Não se considerou, segundo o professor, os casos em que a

22 Ibid., p. 17.

23 "Há, pois, necessidade de se atentar com muita agudeza para a gravidade da decisão que pretender desconsiderar a personalidade jurídica. [...] [N]ão devemos imaginar que a penetração do véu da personalidade jurídica e a desconsideração da pessoa jurídica se torne instrumento dócil nas mãos inábeis dos que, levados ao exagero, acabassem por destruir o instituto da pessoa jurídica, construído através de séculos pelo talento dos juristas dos povos civilizados [...]." (Ibid., p. 24).

24 Ibid., p. 21-24. Sobre a obra de Requião, vide também SALOMÃO FILHO, 2006, p. 226-227; NUNES; BIANQUI, 2009, p. 308-309.

25 SALOMÃO FILHO, 2006, p. 227. 
desconsideração é promovida em benefício do controlador, sem qualquer abuso ou fraude. ${ }^{26}$

Sendo assim, Comparato sustenta que o verdadeiro critério a ser utilizado para a aplicação da desconsideração da personalidade jurídica está ligado à interpretação funcional da personalização.

Toda pessoa jurídica é criada para o desempenho de funções determinadas, gerais e especiais. A função geral da personalização de coletividades consiste na criação de um centro de interesses autônomo, relativamente às vicissitudes que afetam às pessoas físicas que lhe deram origem, ou que atuam em sua área: fundadores, sócios, administradores. As funções específicas variam, conforme as diferentes categorias de pessoas jurídicas e ainda dentro de cada categoria, de coletividade a coletividade, em razão de seus atos constitutivos, estatutos ou contratos sociais.

\section{Comparato prossegue:}

A desconsideração da personalidade jurídica é operada como conseqüência de um desvio de função, ou disfunção, resultante, sem dúvida, no mais das vezes, de abuso ou fraude, mas que nem sempre constitui um ato ilícito. Daí porque não se deve cogitar da sanção de invalidade, pela inadequação de sua excessiva amplitude, e sim da ineficácia relativa. ${ }^{27}$

Em outras palavras, como ensina Salomão, para Comparato a função da personalização é a criação de um centro de interesses autônomo e, na ausência deste centro de interesses, estaria autorizado o uso da teoria da desconsideração da personalidade jurídica. $^{28}$

26 Como exemplo desta situação, Comparato cita a interpretação ampliativa feita pela jurisprudência brasileira ao art. $8^{\circ}$, alínea $e$, do Decreto $\mathrm{n}^{\circ}$ 24.150/1934 (revogado pela Lei $\mathrm{n}^{\circ}$ 8.245/91, promulgada posteriormente à publicação da primeira edição da obra de Comparato), que permitia a retomada de imóvel, na locação de prédio de fundo de comércio, por sociedade cujo controlador é proprietário do prédio. Para o autor, a jurisprudência alargou o alcance da norma legal, que permitia a retomada do imóvel para uso próprio do locador, quando a Súmula 486 do Supremo Tribunal Federal admitiu "a retomada para a sociedade da qual o locador, ou seu cônjuge, seja sócio, com participação predominante no capital social". Para Comparato, " "uso próprio do locador', de acordo com esta interpretação pretoriana, corresponde à utilização por sociedade de que o locador ou seu cônjuge sejam controladores." (COMPARATO; SALOMÃO FILHO, 2008, p. 355-356). Sobre a desconsideração da personalidade jurídica em benefício do sócio, vide SALOMÃO FILHO, op. cit., p. 224-226.

27 COMPARATO; SALOMÃO FILHO, 2008, p. 356.

28 SALOMÃO FILHO, 2006, p. 227. 
Ainda segundo Comparato, nos grupos societários esta situação (de desaparecimento de um centro de interesses autônomo, que ensejaria a desconsideração da personalidade jurídica) é especialmente notória. Para Salomão, Comparato substitui o unitarismo subjetivo de Serick por um método objetivo, mas da mesma maneira unitário. ${ }^{29}$

\subsubsection{A dupla crise da pessoa jurídica de J. Lamartine Corrêa de Oliveira}

Outra importante contribuição à admissão da teoria da desconsideração da personalidade jurídica pelo direito brasileiro é a obra de Oliveira.

Para este autor, a principal função da personalidade jurídica é a separação patrimonial. Embora reconheça que a responsabilidade limitada não decorra necessariamente da personalidade jurídica, entende o autor que a limitação da responsabilidade seria a expressão máxima do princípio da separação entre a pessoa jurídica e seus membros. ${ }^{30}$

A desconsideração da personalidade jurídica das sociedades com responsabilidade $\operatorname{limitada}^{31}$ seria, então, conseqüência de uma crise de função da pessoa jurídica. ${ }^{32}$

29 Ibid., p. 227. No mesmo sentido, NUNES; BIANQUI, 2009, p. 310: "Olha o autor [Comparato] a desconsideração sempre a partir da óptica do controle societário, afirmando que a perda da autonomia da gestão empresarial (que ocorre com freqüência nos grupos econômicos), traduz-se sempre pelo sacrifício dos interesses de cada sociedade no interesse global do grupo. O critério para a desconsideração da pessoa jurídica está nos pressupostos da separação patrimonial e não no uso que se faz dela. A partir disso, afasta ele o subjetivismo trazido por Rolf Serick e traça uma concepção objetiva da teoria, embutida no próprio conceito de pessoa jurídica, classificando os fundamentos da desconsideração a partir dos negócios que são feitos, em: interna corporis (desvio de poder e fraude) ou externa corporis (confusão patrimonial). A crítica que faz ao subjetivismo reside em dois fundamentos: afirma ele que inexiste, nos trabalhos de Serick, Verrucoli e Requião um aprofundamento teórico acerca da desconsideração e sua relação ontológica com o conceito de pessoa jurídica, bem como a formulação subjetiva não contempla a situação de disregard em relação ao controlados ou à própria sociedade, que é o caso da súmula n. 486 do STF sobre a Lei de Luvas."

30 OLIVEIRA, 1979, p. 261-263.

31 Em sua obra, Oliveira propõe-se a analisar apenas a crise de função das sociedades de responsabilidade limitada.

32 "Na verdade, o que as páginas seguintes irão demonstrar é a existência de uma crise de função da pessoa jurídica de Direito Privado. De modo especial, da função das sociedades e, de modo ainda mais especial, das anônimas e das por quotas de responsabilidade limitada. Não se trata de uma simples alteração de necessidades levando a uma utilização do instituto para necessidades novas, não previstas pelo legislador. Tal fenômeno é sempre possível, desde que as novas necessidades e a sua satisfação guardem relação de conformidade com os grandes princípios informadores do ordenamento jurídico. Trata-se, ao contrário, da 
Oliveira aproxima-se de Comparato ao sustentar que o maior foco de incidência sobre esta crise de função da pessoa jurídica são as sociedades unipessoais e os grupos de sociedades, mas critíca a opinião do último ao sustentar que a desconsideração da personalidade jurídica da sociedade controlada para imputação de responsabilidade à controladora, com fundamento e mera situação de controle, seria mais que desconsiderar; seria colocar em dúvida todo o sistema, pelo qual a criação de um grupo de sociedades não afeta o quadro das pessoas jurídicas, na medida em que não extingue a personalidade das sociedades grupadas nem cria personalidade jurídica distinta para o grupo. ${ }^{33}$

Finalmente, vale destacar que Oliveira adverte que casos de mera imputação de ato não podem ser confundidos com casos de desconsideração. Nos casos de imputação de um ato próprio, a solução estaria na aplicação de institutos do direito civil, e não da desconsideração. ${ }^{34}$

Aqui, vale a crítica de Salomão. Para este autor, quando chegou o momento de definir os casos de desconsideração propriamente dita, Oliveira admite que, mesmo nestas hipóteses, os problemas são freqüentemente de imputação.

A única diferença real para o autor entre desconsideração e mera imputação de atos parece, portanto, residir no fato de que nos casos de desconsideração ocorre imputação de responsabilidade por dívida alheia, o que não se verifica nos demais casos em que há imputação de ato próprio, com relação aos quais deverse-iam aplicar os institutos civilísticos. ${ }^{35}$

\subsection{Nota sobre a experiência dos tribunais brasileiros}

Segundo indica Salomão, a jurisprudência brasileira, influenciada pela doutrina descrita anteriormente, atribui valor paradigmático à personalidade jurídica e reafirma que

utilização do instituto na busca de finalidades consideradas em contradição com tais princípios básicos. E da reação que os tribunais desenvolveram através de um conjunto de julgados que tiverem por ponto comum uma espécie de suspensão de vigência - para o caso concreto em julgamento - do princípio da separação entre pessoa jurídica e pessoa-membro. Esse fenômeno é conhecido pelo pensamento jurídico moderno pelas expressões 'desconsideração' da pessoa jurídica (tradução aproximada da expressão norteamericana 'disregard of the legal entity') ou 'penetração' na pessoa jurídica (aproximada tradução do alemão ‘Durchgriff').” (Ibid., p. 262-263).

33 Conforme OLIVEIRA, op. cit., p. 594-595; NUNES; BIANQUI, 2009, p. 312.

34 Conforme NUNES; BIANQUI, op. cit., p. 312; SALOMÃO FILHO, 2006, p. 228-229.

35 SALOMÃO FILHO, 2006, p. 229. 
a sua desconsideração somente pode ser admitida em caso de previsão legal expressa ou de comportamentos fraudulentos.

Os julgados brasileiros, segundo o autor, podem ser classificados segundo o fundamento jurídico invocado para fundamentar a desconsideração, sendo os casos mais recorrentes de dois tipos: fundamentação em dispositivos legais e demonstração de abuso ou fraude à lei.

No primeiro caso, a desconsideração é determinada com fundamento em dispositivos legais presentes no ordenamento que a autorizam. É o caso, por exemplo, do art. $2^{\circ}, \S 2^{\circ}$ da Consolidação das Leis do Trabalho (CLT) e do art. 28 do Código de Defesa do Consumidor (CDC), entre outros que serão analisados a seguir. Salomão indica que esta classificação também inclui os casos de decisões que buscam fundamentos para a desconsideração no direito civil, usando regras de nulidade, anulação e fim ilícito.

No segundo caso, como não existe fundamento legal que autorize a desconsideração, a jurisprudência busca demonstrar a existência de abuso ou fraude à lei no comportamento do sócio majoritário para justificar a aplicação da teoria. ${ }^{36-37}$

\subsection{Previsão legal de casos de desconsideração no ordenamento brasileiro}

Segundo a doutrina, há previsão legal de casos de desconsideração da personalidade jurídica em diversos diplomas legais do ordenamento jurídico brasileiro. Segue, portanto, uma breve análise de cada um destes dispositivos, com algumas críticas que serão importantes para o desenvolvimento deste trabalho.

36 Ibid., p. 229-233, com ampla referência jurisprudencial. Note-se que Salomão critica a pouca frequiência da desconsideração da personalidade jurídica em sociedades anônimas. Para o autor, a existência de um maior número de regras organizativas nas sociedades anônimas poderia justificar a não aplicação de critérios objetivos de desconsideração às sociedades anônimas, mas não pode afastar em absoluto a desconsideração nestes tipos societários, especialmente nos casos de atividade irregular ou fraudulenta.

37 Este item é uma breve nota sobre o tratamento dado nos julgados brasileiros a respeito da desconsideração da personalidade jurídica. No capítulo seguinte, há uma análise mais detalhada de julgados recentes a respeito do tema, mas direcionado ao escopo desta dissertação, a saber, a desconsideração da personalidade jurídica nos grupos de fato por subordinação. 


\subsubsection{O art. $2^{\circ}, \S 2^{\circ} \mathrm{da} C L T$}

O caput do art. $2^{\circ}$ da CLT determina que "considera-se empregador a empresa, individual ou coletiva, que, assumindo os riscos da atividade econômica, admite, assalaria e dirige a prestação pessoal de serviço". Mais adiante, o $\S 2^{\circ}$ dispõe que "sempre que uma ou mais empresas, tendo, embora, cada uma delas, personalidade jurídica própria, estiverem sob a direção, controle ou administração de outra, constituindo grupo industrial, comercial ou de qualquer outra atividade econômica, serão, para os efeitos da relação de emprego, solidariamente responsáveis a empresa principal e cada uma das subordinadas."

Este dispositivo é comumente identificado pela doutrina como previsão legal de desconsideração da personalidade jurídica nas sociedades integrantes de grupos societários em benefício de trabalhadores. Essa é, por exemplo, a posição de Requião. ${ }^{38}$

A intenção do legislador em inserir tal dispositivo na CLT parece bastante clara. O objetivo da norma é tutelar o interesse do trabalhador, protegido constitucionalmente. Entretanto, em que pese a opinião de sensível parte da doutrina, este dispositivo não parece ser propriamente um caso de desconsideração da personalidade jurídica, mas sim de imposição de responsabilidade solidária por força de lei.

Como salientam Nunes e Bianqui, o dispositivo supra mencionado da CLT não faz qualquer menção a fraude ou qualquer tipo de abuso na utilização da pessoa jurídica, para que se pudesse falar em desconsideração. ${ }^{39}$ Neste caso, parece que o que comumente se identifica com a desconsideração é na verdade uma questão de política legislativa: entre a satisfação do crédito trabalhista e a separação patrimonial, fica-se com a primeira. ${ }^{40}$

38 "Quando a Consolidação das Leis do Trabalho, por exemplo, no art. $3^{\circ}\left[2^{\circ}\right]$, concebe como uma única entidade econômica a união de empresas, ou entre a empresa 'mater' e suas filiadas, para os efeitos do direito social, nada mais está admitindo senão a aplicação da doutrina [da desconsideração da personalidade jurídica], pois despreza e penetra o 'véu' que as encobre e individualiza, desconsiderando a personalidade independente de cada uma das subsidiárias.” (REQUIÃO, 1969, p. 20). No mesmo sentido, vide nota de rodapé no 53 em NUNES; BIANQUI, 2009, p. 320.

39 NUNES; BIANQUI, 2009, p. 320.

40 Vale transcrever Walfrido Jorge Warde Júnior: "Diante de dois bens jurídicos, o magistrado prefere um em detrimento do outro. A escolha ganha suporte de uma reflexão de natureza ético-econômica em que o juiz se convence - para usar a terminologia do Law and Economics - da ineficiência da limitação de responsabilidade. Esse juízo e seus fundamentos (ético-econômicos) serão, nesses casos, as únicas causas de imputação de responsabilidade. As freqüentes referências à teoria da desconsideração da personalidade 
Para Barros, a CLT optou por sobrepor a evidência de uma realidade sócioeconômica ao formalismo jurídico quando determinou a responsabilidade solidária de empresas do mesmo grupo para efeitos da relação de emprego. Para esta autora, o grupo é o verdadeiro empregador, tratando a "empresa" não como uma sociedade isolada, mas sim como uma categoria econômica. ${ }^{41}$

\subsubsection{O art. 28 do CDC}

Situação muito semelhante à descrita acima pode ser verificada no CDC, instituído pela Lei no $8.078 / 90$.

O caput do seu art. 28 determina: "O juiz poderá desconsiderar a personalidade jurídica da sociedade quando, em detrimento do consumidor, houver abuso de direito, excesso de poder, infração da lei, fato ou ato ilícito ou violação dos estatutos ou contrato social. A desconsideração também será efetivada quando houver falência, estado de

\footnotetext{
jurídica são evidente técnica para que - apenas formalmente - não se possa falar em judge-made law. Na larga maioria das vezes, imputa-se responsabilidade aos sócios sem que existam, nos autos, quaisquer provas de abuso de direito, fraude, abuso da personalidade jurídica, desvio de finalidade, i.e., as razões mais recorrentes à aplicação da teoria da desconsideração. Basta que se verifique a insolvência ou o esgotamento do patrimônio social, prescindindo-se, por completo, da prova das causas que impedem a sociedade de adimplir o crédito trabalhista, para que se impute responsabilidade aos sócios [...]. Essa é, apenas para refutar a pecha de exceção, conduta consolidada em matéria trabalhista. De resto, observa-se, em razão do privilégio, a especialidade do crédito em tela, cuja satisfação não pode ser obstaculizada pela limitação da responsabilidade. Do mesmo modo, a despeito de pretender-se aplicada a disregard doctrine, dá-se imputação de responsabilidade pela simples insuficiência do patrimônio social [...]. No caso específico da responsabilidade grupal, a norma do $\S 2^{\circ}$, do artigo $2^{\circ}$ da Consolidação das Leis do Trabalho torna desnecessário - para mascarar um juízo acerca da ineficiência da limitação da responsabilidade - o apelo à teoria da desconsideração. A determinação legal, nesse particular, tem a sociedade controladora como empregadora (por determinação do $\S 2^{\circ}$ cumulado com o caput do artigo $2^{\circ}$ da CLT) e, conseqüentemente, diante da apropriação e organização empresarial do trabalho como meio de produção, também como co-titular da atividade empresarial desenvolvida pela controlada [...]. A norma em destaque contém presunção absoluta de que, para os fins do direito do trabalho, sobreponham-se - em vista do seu exercício pela mesma pessoa - os, conceitualmente distintos, controles empresarial e societário. Presume-se que o controlador não só influencie a vontade social, mas também exerça a empresa. Por esse motivo, é solidária e ilimitadamente responsável. E como o $\S 2^{\circ}$ refere-se, erroneamente, a um esquema de controle e subordinação entre empresas, e não entre pessoas, há mesmo quem amplie - por existirem empresas individuais e societárias - o âmbito de aplicação da norma ao controlador que seja pessoa física. No direito o trabalho, portanto, é claramente constatado que a imputação de responsabilidade aos sócios é consequiência de juízos ético-econômicos realizados tanto pelo magistrado, quanto pelo legislador." (WARDE JÚNIOR, 2007, p. 289-295).

41 BARROS, 1992, p. 170.
} 
insolvência, encerramento ou inatividade da pessoa jurídica provocados por má administração."

Adiante, o $\S 5^{\circ}$ do mesmo artigo prevê: “Também poderá ser desconsiderada a pessoa jurídica sempre que sua personalidade for, de alguma forma, obstáculo ao ressarcimento de prejuízos causados aos consumidores."

Assim como a proteção ao trabalhador, a proteção ao consumidor é constitucionalmente protegida (art. $5^{\circ}, \mathrm{XXXII}, \mathrm{CF} / 88$ ). Desta forma, o raciocínio que se aplica para a inserção, no CDC, de previsão de desconsideração da personalidade jurídica, segue a mesma linha descrita acima para o caso de proteção de trabalhadores: trata-se de uma escolha do legislador de proteger o crédito do consumidor em detrimento da separação patrimonial.

Especialmente no $\S 5^{\circ}$ do art. 28 , não há qualquer referência aos requisitos que normalmente são considerados para justificar a desconsideração, como a fraude ou abuso de direito. A personalidade jurídica pode ser desconsiderada sempre que for "obstáculo ao ressarcimento de prejuízos causados aos consumidores".

Como ensina Warde Júnior:

O legislador, particularmente no que concerne ao $\S 5^{\circ}$ do artigo 28 , desprezou os critérios de desconsideração. A referência à disregard doctrine decorre somente da necessidade, diante da crença de que a limitação de responsabilidade resulte da personalidade jurídica, de eleger uma técnica capaz de imputar aos sócios a responsabilidade pelas dívidas da sociedade. De resto, não é possível encontrarse no suporte fático da norma em tela, as características da teoria da desconsideração. Torna-se claro, portanto, que o legislador, preferindo a satisfação do crédito do consumidor à limitação da responsabilidade dos sócios da sociedade devedora, pretendeu abrogar - relativamente às questões de consumo - as normas dos artigos 1.045, 1.052 do Código Civil e $1^{\circ}$ da Lei de Sociedades Anônimas."42

$42 \mathrm{O}$ art. 28 do CDC é considerado pela doutrina a primeira previsão legal de desconsideração da personalidade jurídica no direito brasileiro, que até então era aplicada pelos nossos tribunais como teoria. Com relação a isso, importante destacar a observação de Warde Júnior no sentido de que o caput do art. 28 lista os critérios mais frequientes de aplicação da teoria da desconsideração, além de incluir algumas inovações. Contudo, em algumas das hipóteses ali listadas, a imputação de responsabilidade se funda em atos e situações que evidenciam, a aquisição e exercício, por parte dos sócios, de poder de controle empresarial (conforme WARDE JÚNIOR, 2007, p. 297-298). 
Merece destaque a previsão do $\S 2^{\circ}$ do art. 28 do $\mathrm{CDC}$, que determina que sociedades integrantes de grupos societários e sociedades controladas são subsidiariamente responsáveis pelas obrigações decorrentes do CDC. Note-se que aqui não se fala em desconsideração, mas sim em responsabilidade subsidiária, regra menos severa que a prevista na CLT, indicada acima.

Para Muniz, esta norma do CDC:

[...] baseia-se no fato de que os bens de um grupo empresarial estão divididos entre as pessoas jurídicas dele integrantes de acordo com as conveniências econômicas e administrativas de seus sócios. Por isso, muitas vezes uma sociedade não possui recursos para cumprir com suas obrigações, apesar de pertencer a um grupo econômico sólido financeiramente.

O autor complementa sustentando que, embora essa regra possa ser justa em alguns casos, ela é um duro golpe no princípio da autonomia patrimonial dos sócios, especialmente considerando a falta de regulamentação adequada dos grupos de sociedades no direito brasileiro. ${ }^{43}$

Esta observação não afasta, contudo, o caráter de proteção a interesse constitucionalmente garantido conferido à desconsideração da personalidade jurídica prevista nos casos aqui descritos.

\subsubsection{O art. $4^{\circ}$ da Lei $n^{\circ} 9.605 / 98$}

A Lei $n^{\circ}$ 9.605/98 dispõe sobre sanções penais e administrativas derivadas de condutas e atividades lesivas ao meio ambiente, determina em seu art. $4^{\circ}$ que "poderá ser desconsiderada a pessoa jurídica sempre que sua personalidade for obstáculo ao ressarcimento de prejuízos causados à qualidade do meio ambiente".

${ }^{43}$ MUNIZ, 2003, p. 162-163. 
Por ter redação bastante semelhante à do $\S 5^{\circ}$ do art. 28 do CDC, a desconsideração da personalidade jurídica prevista neste diploma para a proteção do meio ambiente tem a mesma fundamentação e a mesma crítica prevista para o caso previsto no CDC. O legislador entendeu que a personalidade jurídica não pode ser um óbice para a proteção do meio ambiente. ${ }^{44}$

Esta opção do legislador é bem explicada por Silva:

As normas constitucionais assumiram a consciência de que o direito à vida, como matriz de todos os demais direitos fundamentais do homem, é que há de orientar todas as formas de atuação no campo da tutela do meio ambiente. Compreendeu que ele é um valor preponderante, que há de estar acima de quaisquer considerações como as de desenvolvimento, como as de respeito ao direito de propriedade, como as de iniciativa privada. Também estes são garantidos no texto contitucional, mas, a toda evidência, não podem primar sobre o direito fundamental à vida, que está em jogo quando se discute a tutela do meio ambiente, que é instrumental no sentido de que, através dessa tutela, o que se protege é um valor maior: a qualidade da vida humana. ${ }^{45}$

\subsubsection{O art. 135 da Lei $n^{\circ} 5.172 / 66$}

44 “A compensação adequada do sentido inspirador da teoria da desconsideração da personalidade jurídica, como dissemos, faz compreender que a sua aplicação deve ser dirigida, realmente, apenas àquelas situações que caracterizam um desvio de função através do uso da personalidade jurídica, seja em razão de condutas pessoais dos sócios, seja pela confusão patrimonial. Fora daí, não há espaço para a incidência da teoria da desconsideração. Por isso, a nosso ver, nos casos em exame, tecnicamente, não há desconsideração da personalidade jurídica, porque não há qualquer desvio no uso da pessoa jurídica decorrente de ato praticado pelo sócio, apenas há a responsabilidade patrimonial por dívida alheia, tendo por pressuposto a falta, da pessoa jurídica, fundada na sua função social, de forma a garantir a reparação dos danos causados ao consumidor ou ao meio ambiente, independentemente do fato de a pessoa jurídica ser a única causadora dos danos. Nesses casos, nos termos dos preceitos citados, 'desconsidera-se' a existência da pessoa jurídica, atingindo-se os bens pessoais do sócio, tudo em conformidade com os novos valores e princípios que hoje passaram a ganhar relevo pelo Texto Constitucional. Isso porque a defesa do consumidor e do meio ambiente passaram, por força constitucional, à categoria de princípios gerais da atividade econômica, de forma que os danos a eles causados devem ser efetivamente reparados, independentemente de outros valores ou dogmas." (BANDEIRA, Gustavo. Dano ambiental e violação da função social da pessoa jurídica. Fundamento para a Responsabilização Patrimonial do sócio: relativização da pessoa jurídica. Revista da EMERJ, v. 7, n. 28, p. 167-203, 2004, p. 200). Vide também os comentários a respeito da desconsideração da personalidade jurídica em casos de crimes ambientais em MUNIZ, 2003, p. 163-164.

45 SILVA, José Afonso da. Curso de Direito Constitucional Positivo. 18. ed. São Paulo: Malheiros, 2000, p. 822. 
A Lei $n^{\circ} 5.172 / 66$, que estabelece o Código Tributário Nacional (CTN), determina em seu art. 135 que

[...] são pessoalmente responsáveis pelos créditos correspondentes a obrigações tributárias resultantes de atos praticados com excesso de poderes ou infração de lei, contrato social ou estatutos [...] os diretores, gerentes ou representantes de pessoas jurídicas de direito privado.

Este artigo é comumente apontado pela doutrina como previsão legal de desconsideração da personalidade jurídica, na medida em que imputa responsabilidade aos administradores e/ou representantes das pessoas jurídicas de direito privado por créditos tributários decorrentes de atos praticados com excesso de poder ou infração à lei ou atos constitutivos.

A afirmativa em nada parece correta. Neste caso, não se trata de previsão de desconsideração da personalidade jurídica, mas sim de regra de imputação de responsabilidade civil a administradores. O mesmo vale para o art. 158 , caput e $\S 2^{\circ}$ da LSA $^{46}$ e para o art. 1016 do atual Código Civil ${ }^{47}$, que costumam também ser confundidos com casos de previsão legal de desconsideração da personalidade jurídica, quando são, igualmente, regras de imputação de responsabilidade.

\section{Conforme Nunes e Bianqui:}

É importante ressaltar que tais normas de imputação de responsabilidade civil aos administradores que ajam fora dos limites do estatuto ou contrato social, praticando ato ilícito, encontram-se dentro da disciplina do Direito Societário.

Não há que se falar, portanto, da desconsideração da personalidade jurídica para atingi-los; eles respondem como pessoas físicas por ilícitos pessoais, em função de aplicação de dispositivo legal. ${ }^{48}$

46 “Art. 158. O administrador não é pessoalmente responsável pelas obrigações que contrair em nome da sociedade e em virtude de ato regular de estão; responde, porém, civilmente, pelos prejuízos que causar, quando proceder: I - dentro de suas atribuições ou poderes, com culpa ou dolo; II - com violação de lei ou estatuto. [...] $\S 2^{\circ}$. Os administradores são solidariamente responsáveis pelos prejuízos causados em virtude do não cumprimento dos deveres impostos por lei para assegurar o funcionamento normal da companhia, ainda que, pelo estatuto, tais deveres não caibam a todos eles."

47 "Art. 1016. Os administradores respondem solidariamente perante a sociedade e os terceiros prejudicados, por culpa no desempenho de suas funções."

48 NUNES; BIANQUI, 2009, p. 322. 
A mesma observação é feita por Muniz: "Entretanto, nas hipóteses constantes das normas acima mencionadas [dentre as quais o autor cita o art. 135 do CTN], a responsabilização pessoal dos sócios não advém da disregard doctrine, mas sim da prática de atos ilícitos." ${ }^{49}$

Ainda com relação ao CTN, Nunes e Bianqui chamam a atenção para outro dispositivo.

A Lei Complementar $n^{\circ}$ 104/2001 acrescentou um $\S$ único ao art. 116 do CTN, estabelecendo que:

[...] a autoridade administrativa poderá desconsiderar atos ou negócios jurídicos praticados com a finalidade de dissimular a ocorrência do fato gerador do tributo ou a natureza dos elementos constitutivos da obrigação tributária, observados os procedimentos a serem estabelecidos em lei ordinária.

O texto legal é vago e, conforme indicam Nunes e Bianqui, ainda não se conhece a extensão desta inovação legal. Se a autoridade administrativa pode desconsiderar "atos e negócios jurídicos" praticados com a finalidade de dissimular a ocorrência do fato gerador do tributo ou a natureza dos elementos constitutivos da obrigação tributária, não parece impossível afirmar que o contrato de sociedade possa estar entre tais atos e negócios jurídicos que possam ser desconsiderados.

Estar-se-ia diante de uma nova previsão de legal de caso de desconsideração da personalidade jurídica? A prática vai dizer. ${ }^{50}$ Há ação direta de inconstitucionalidade em trâmite perante o Supremo Tribunal Federal acerca da constitucionalidade do referido dispositivo, ainda sem julgamento. ${ }^{51}$

49 MUNIZ, 2003, p. 160.

50 "Novamente, aqui nos parece que mecanismo distinto e de efeitos muito mais amplos do que a aplicação do princípio da desconsideração da personalidade jurídica está prestes a ser incorporado no ordenamento jurídico brasileiro, eis que seria efetivada uma 'desconsideração': (i) por um fiscal, sem a participação do Judiciário; (ii) não haveria a necessidade de prática fraudulenta ou de qualquer forma de abuso de direito e (iii) não seria respeitado o direito à defesa do sócio que terá seu patrimônio pessoa comprometido." (NUNES; BIANQUI, 2009, p. 321).

51 Ação Direta de Inconstitucionalidade (ADIN) nº 2446/2001. 


\title{
3.4.5 O art. 18 da Lei $n^{\circ} 8.884 / 94$
}

A Lei $\mathrm{n}^{\circ} 8.884 / 94$, que dentre outras questões disciplina as infrações contra a ordem econômica, determina em seu art. 18 que:

\begin{abstract}
A personalidade jurídica do responsável por infração da ordem econômica poderá ser desconsiderada quando houver da parte deste abuso de direito, excesso de poder, infração da lei, fato ou ato ilícito ou violação dos estatutos ou contrato social. A desconsideração também será efetivada quando houver falência, estado de insolvência, encerramento ou inatividade da pessoa jurídica provocados por má administração.
\end{abstract}

O raciocínio a ser aqui aplicado é o mesmo já descrito anteriormente. Preferiu o legislador privilegiar a ordem econômica, que tem proteção constitucional, em detrimento da separação patrimonial. Na síntese de Nunes e Bianqui:

[O]s artigos de lei aqui trazidos para estudo têm por objetivo tutelar valores constitucionalmente previstos ou mesmo o patrimônio público, o que já confere a este grupo de normas um certo destaque que é, inclusive, reconhecido por parte da doutrina ao diferenciar credores como o Fisco, os empregados e a coletividade dos credores 'privados', alegando, alegando que os últimos puderam avaliar os riscos, bem como protegerem-se com garantias adequadas quando da constituição da dívida. Por outro lado, os primeiros, que não tiveram tal oportunidade, deveriam ser privilegiados com a aplicação da desconsideração de modo a terem mais chances de verem seus créditos ressarcidos. ${ }^{52}$

\subsubsection{O art. 50 do atual Código Civil}

Os artigos de lei tratados anteriormente, nos quais há previsão de casos de desconsideração da personalidade jurídica (ainda que alguns deles mereçam críticas), foram inseridos no ordenamento brasileiro antes da promulgação da Lei $n^{\circ} 10.406 / 02$, que instituiu o atual Código Civil.

52 NUNES; BIANQUI, op. cit., p. 324. 
Sendo assim, até a entrada em vigor do atual Código Civil, a desconsideração da personalidade jurídica era aplicada por nossos tribunais: (i) com invocação da teoria, independente de qualquer previsão legal, nos casos de abuso de direito ou fraude; e (ii) nos casos previstos em lei descritos anteriormente.

$\mathrm{O}$ art. 50 do atual Código Civil, contudo, pretendeu sistematizar a teoria da desconsideração da personalidade jurídica em seu art. 50, o qual determina que:

[...] em caso de abuso da personalidade jurídica, caracterizado pelo desvio de finalidade, ou pela confusão patrimonial, pode o juiz decidir, a requerimento da parte, ou do Ministério Público quando lhe couber intervir no processo, que os efeitos de certas e determinadas relações de obrigações sejam estendidos aos bens particulares dos administradores ou sócios da pessoa jurídica. ${ }^{53}$

53 Essa não era, contudo, a redação original proposta no primeiro Anteprojeto de Código Civil. Inicialmente, o texto dizia: "Art. 49. A pessoa jurídica não pode ser desviada dos fins que determinaram a sua constituição, para servir de instrumento ou cobertura à prática de atos ilícitos, ou abusivos, casos em que caberá ao juiz, a requerimento do lesado ou do Ministério Público, decretar-lhe a dissolução. Parágrafo único. Neste caso, sem prejuízo de outras sanções cabíveis, responderão, conjuntamente com os da pessoa jurídica, os bens pessoais do administrador ou representante que dela se houver utilizado de maneira fraudulenta ou abusiva, salvo se norma especial determinar a responsabilidade solidária de todos os membros da administração". Essa redação foi objeto de crítica de Lamartine, que acreditava que o texto proposto não correspondia às idéias básicas da teoria da desconsideração, na medida em que misturava os conceitos de desconsideração e dissolução da sociedade. Lamartine chega inclusive a citar a opinião de Requião, para o qual da redação originalmente proposta não reflete adequadamente a teoria da desconsideração, pois pune os sócios inocentes com a dissolução da sociedade. Em 1973, em vista das críticas recebidas pela doutrina, a redação do caput do artigo citado acima foi alterada para (o parágrafo único permaneceu inalterado): “A pessoa jurídica não pode ser desviada dos fins estabelecidos no ato constitutivo, para servir de instrumento ou cobertura à prática de atos ilícitos, ou abusivos, caso em que poderá o juiz, a requerimento de qualquer dos sócios ou do Ministério Público, decretar a exclusão do sócio responsável, ou tais sejam as circunstâncias, a dissolução da entidade”. Esse texto foi mantido no Projeto $n^{\circ}$ 634/1975, que foi enviado à Câmara dos Deputados, mas não ficou livre de novas críticas da doutrina. Lamartine indica que Requião foi feliz em suas duas principais críticas à nova redação. Em primeiro lugar, não se deveria conferir legitimidade ao Ministério Público nem aos sócios para pedir a desconsideração, apenas aos credores insatisfeitos. Em segundo lugar, quando se fala em desconsideração, não há que se falar em dissolução da sociedade, mas sim em deixar de levar em conta a sua autonomia no caso concreto. Requião chegou a sugerir uma nova redação para este artigo, mas a redação proposta, na opinião de Lamartine, limitava a aplicação da desconsideração apenas àqueles casos em que se atinge a sociedade para atender a pretensão de credor do sócio (o texto proposto por Requião dizia: "A pessoa jurídica não pode ser desviada dos fins que determinam a sua constituição, para servir de instrumento ou cobertura à prática de atos ilícitos ou abusivos de sócio. Neste caso, o juiz, desconsiderando a existência da personalidade jurídica, a pedido do credor do sócio, poderá permitir a efetivação de sua responsabilidade sobre os bens incorporados na sociedade para a sua participação no capital social"). Comparato também criticou a redação do Projeto de Código Civil. Como visto acima, este autor aborda a questão da desconsideração sob a ótica do poder de controle e, portanto, o verdadeiro pressuposto da desconsideração seria a confusão patrimonial, e não o abuso de direito ou a fraude. Para Comparato, a redação proposta pecava no parágrafo único ao mencionar administradores e representantes e deixar de mencionar o controlador que não administra nem representa a pessoa jurídica. Durante a tramitação no Congresso Nacional, a matéria foi objeto de diversas modificações, sendo então aprovada com a redação que consta no corpo do texto desta dissertação (conforme OLIVEIRA, 1979, p. 555-558; MUNHOZ, 2002, p. 164-166; KOURY, 1998, p. 143-144). 
Aqui vale transcrever as observações de Munhoz:

De forma coerente com a doutrina mais abalizada, [o art. 50 do atual Código Civil] define a desconsideração como uma suspensão provisória, em situações determinadas, do princípio da separação entre pessoa jurídica e seus sócios e administradores (não apenas administradores, como na versão original). Também coerente com a melhor doutrina foi a definição do abuso do instituto, ou seja, do abuso da personalidade jurídica, como pressuposto da desconsideração, estabelecendo-se, desde logo, as hipóteses de desvio de finalidade e de confusão patrimonial, como caracterizadoras da situação abusiva. Apesar desses inegáveis avanços, não se pode deixar de reconhecer que o dispositivo não será suficiente para eliminar a incerteza que atualmente cerca a matéria, pois remanescerá aos juízes ampla margem para interpretar os conceitos indeterminados nele previstos (abuso da personalidade jurídica, desvio de finalidade, confusão patrimonial), segundo os critérios que pareçam mais adequados à justiça do caso concreto. Essa parece constituir uma crítica, porém, que não se dirige ao dispositivo em exame, mas à própria teoria da desconsideração $[\ldots]^{54}$

$\mathrm{O}$ art. 50 do atual Código Civil merece destaque pois os outros dispositivos legais que tratam do tema (CLT, CDC, legislação ambiental, etc., mencionadas acima) são normas especiais e aplicam-se somente às relações jurídicas a que se referem. A regra de desconsideração da personalidade jurídica prevista no Código Civil, em contrapartida, é norma geral, aplicável a todas as relações jurídicas privadas. Como ensinam Gagliano e Pamplona:

[...] a grande virtude, sem sobra de qualquer dúvida, da desconsideração da personalidade jurídica prevista no art. 50 - e todos reconhecem ser esta uma das grandes inovações do $\mathrm{CC}-02$ - é o estabelecimento de uma regra geral de conduta para todas as relações jurídicas travadas na sociedade, o que evita que os operadores do Direito tenham de fazer - como faziam - malabarismos dogmáticos para aplicar a norma - outrora limitada a certos microssistemas jurídicos - em seus correspondentes campos de atuação. ${ }^{55}$

De fato, no que diz respeito à aplicação da desconsideração da personalidade jurídica no caso concreto, pouco se alterou com a sistematização da teoria no Código Civil, pois a redação do art. 50, como dito acima, reflete de maneira de certa forma adequada a doutrina desenvolvida a respeito até então.

54 MUNHOZ, op. cit., p. 166.

55 GAGliANO, Pablo Stolze; PAMPLONA FILHO, Rodolfo. Novo Curso de Direito Civil. São Paulo: Saraiva, 2003. v. I, p. 240. 
A desconsideração aplica-se apenas para um caso particular, sem se negar a personalidade de uma sociedade como um todo. A intenção da doutrina (e do art. 50 do atual Código Civil) é a declaração da ineficácia da personalidade única exclusivamente para um determinado efeito, no caso concreto, em caso de abuso de direito ou fraude para violar a lei e/ou prejudicar credores. Trata-se de medida excepcional que rompe a separação patrimonial antes existente em certas circunstâncias e sob determinados critérios.

Assim, a determinação da desconsideração da personalidade jurídica não determina o rompimento da separação que existe entre a sociedade e seus membros como um todo. A separação subsiste a despeito, e apesar, da imputação do instituto. A desconsideração opera a transferência da responsabilidade de um sujeito para outro e o faz mediante e rompimento do vínculo jurídico anteriormente formado entre a sociedade e o credor da obrigação, estabelecendo uma relação jurídica com o responsável, sócio ou administrador, a quem é imputado o dever de suportar os efeitos da obrigação original. As demais relações da sociedade não sofrem qualquer alteração ${ }^{56}$. Como ensina Coelho: "A aplicação da teoria da desconsideração não implica a anulação ou o desfazimento do ato constitutivo da sociedade empresária, mas apenas a sua ineficácia episódica". 57

Foram, até aqui, tratadas brevemente as regras especiais de desconsideração da personalidade jurídica aplicáveis a relações jurídicas específicas, tais como as relações de trabalho, as relações de consumo, as relações com o meio ambiente e com a ordem econômica etc. A análise mais detalhada destas relações foge ao escopo deste trabalho e, por isso, as seguintes páginas tratarão especificamente a desconsideração da personalidade jurídica aplicável como regra geral às relações societárias, e, posteriormente, especificamente aos grupos de sociedades.

56 ANDRADE FILHO, Edmar Oliveira. A desconsideração da personalidade jurídica no Novo Código Civil. São Paulo: MP, 2005, p. 79-80.

57 COELHO, Fábio Ulhoa. Curso de Direito Comercial. São Paulo: Sarai va, 2002. v. 2, p. 40. 


\subsection{A desconsideração da personalidade jurídica no direito societário}

Segundo Munhoz, no âmbito do direito societário a desconsideração da personalidade jurídica está intimamente ligada ao princípio da responsabilidade limitada. Embora a limitação da responsabilidade não esteja indissociavelmente ligada à personalidade jurídica, no direito societário o que se pretende com a desconsideração é a superação do princípio da responsabilidade limitada, para imputação de responsabilidade a sócios e administradores. Deve-se ter em mente a função sócio-econômica da responsabilidade limitada para se definir as situações em que "se justifica a derrogação da responsabilidade limitada, ou seja, a definição das situações em que esta deixa de ser socialmente desejável." 58

O autor sustenta que a responsabilidade limitada, intimamente relacionada ao desenvolvimento do capitalismo, desempenha funções específicas dependendo do tipo societário a que se refere. Assim, nas sociedades de capital aberto, por exemplo, a responsabilidade limitada permite a diversificação dos investimentos e a dispersão acionária, na medida em que a responsabilidade limitada é pressuposto de existência do mercado de capitais. Nas sociedades de capital fechado, a limitação da responsabilidade é uma regra socialmente desejável de distribuição de riscos, criada para incentivar o desenvolvimento da empresa.

No primeiro caso (das sociedades de capital aberto), os acionistas pouco ou nada interferem nos negócios da sociedade e a eventual exceção ao princípio da responsabilidade limitada se torna pouco defensável. Nas sociedades de capital fechado, a desconsideração deveria ser aplicável àqueles casos em que a exteriorização de $\operatorname{riscos}^{59}$ é excessiva, justificando a extensão da responsabilidade aos seus membros. ${ }^{60}$

Em vista disso, do ponto de vista do direito societário, como indica Munhoz, o problema é que:

58 MUNHOZ, 2002, p. 169.

59 Sobre responsabilidade limitada e exteriorização de riscos, SALOMÃO FILHO, 2006, p. 238-244.

60 MUNHOZ, 2002, p. 170-172. 
[...] a prática tem demonstrado que, em vez de eleger critérios tecnicamente adequados, que permitam a distribuição equilibrada e segura dos riscos inerentes ao exercício da atividade empresarial, a teoria clássica da desconsideração surge como um remédio que ataca a doença (crise da pessoa jurídica) depois que ela se manifesta, definindo casuisticamente as situações em que a exteriorização dos riscos parece excessiva, sem maior preocupação sistemática. A lógica de uma política legislativa, preocupada em criar uma disciplina consentânea com os objetivos sociais, é substituída pela lógica de um remédio jurisprudencial, administrado pelos juízes em caso de patologia. Essa solução casuística acaba por turvar a verdadeira finalidade que deveria orientar a doutrina da desconsideração, qual seja, reequilibrar, numa situação concreta, a distribuição dos riscos da atividade empresarial, segundo os objetivos estabelecidos pelo ordenamento jurídico. ${ }^{6}$

Desta forma, alguns critérios que deveriam ser considerados para a aplicação da teoria da desconsideração da personalidade jurídica no direito societário, tais como o tipo societário em questão, a natureza da relação jurídica objeto da desconsideração ${ }^{62}$, ou se a sociedade é isolada ou integrada em um grupo de sociedades, não são analisados para a aplicação da teoria. ${ }^{63}$

Para Muniz,

61 Ibid., p. 172.

62 Quando se fala em análise da natureza jurídica da relação objeto da desconsideração a doutrina normalmente menciona o tratamento diferenciado que distintas classes de credores estabelecem com a sociedade. A lição de Calixto Salomão Filho neste sentido não poderia ser mais clara: “Assim é que se podem individuar dois grupos de credores [...]. O primeiro grupo é composto pelos credores profissionais ou institucionais, geralmente instituições financeiras. Com relação a eles é possível pressupor a existência de livre mercado. Portanto, com relação a eles pode-se presumir a possibilidade de, com emprego da diligência normal do bom comerciante, informar-se sobre o risco envolvido na transação e, ao mesmo tempo, negociar este risco com a sociedade [...]. O segundo grupo, ao contrário, é composto de todos aqueles credores aos quais não se pode aplicar a hipótese da concorrência perfeita. Nele estão compreendidos, portanto, tanto os credores de delito, que não negociam com a sociedade, como os credores que tiveram a possibilidade teórica mas não efetiva de informar-se sobre a situação da sociedade - ou, em termos mais técnicos: não têm o dever de informar-se em face de seus escassos meios econômicos e do alto custo da informação. E também aqueles que, mesmo informados, não teriam condições de negociar com a sociedade. Esse grupo é composto tipicamente por pequenos fornecedores e empregados. [...] Essa distinção entre credores tem influência direta sobre a desconsideração. Em face dela pode-se sustentar uma aplicação mais restritiva da desconsideração com relação àqueles credores, como os credores institucionais (profissionais) que têm o dever de verificar a situação econômica do devedor e têm a possibilidade de negociar uma taxa de risco. O mesmo deve ser dito com relação a outros credores, se do contrato pode-se depreender claramente a existência de um controle prévio das condições econômicas do devedor e da assunção do risco. Nesse caso, será admissível a desconsideração apenas com base em um aumento superveniente e imprevisível dos riscos, de modo a modificar substancialmente a situação inicial. [...] Com relação ao segundo grupo, no entanto, a desconsideração poderia basear-se em qualquer fato já existente no momento da contratação ou mesmo, caso o objetivo da norma a ser aplicada justificasse, na própria utilidade de imputar uma determinada relação também ao sócio. É o caso, já exemplificado, das disposições a respeito da desconsideração constantes do Código do Consumidor." (SALOMÃO FILHO, 2006, p. 245-247).

63 Conforme MUNHOZ, 2002, p. 173. 
[...] quase todo grupo econômico possui, em maior ou menor grau, certo nível de confusão patrimonial entre seus integrantes. Como o Código Civil de 2002 furtou-se de regular a responsabilidade entre empresas do mesmo grupo, caberá ao poder judiciário delimitar o campo de aplicação da disregrad doctrine nessas situações. $^{64}$

Para os fins deste trabalho, é exatamente esta vertente da desconsideração da personalidade jurídica no âmbito do direito societário que interessa: aquela relacionada às sociedades integradas em grupos. É este aspecto que se tratará no capítulo seguinte.

64 MUNIZ, 2003, p. 167. 


\section{CAPÍTULO 4}

\section{A DESCONSIDERAÇÃO DA PERSONALIDADE JURÍDICA NOS GRUPOS DE SOCIEDADES}

Neste capítulo, tratar-se-á da desconsideração da personalidade jurídica aplicada aos grupos de sociedades. Inicialmente, cumpre ressaltar que, conforme descrito no capítulo anterior, a análise será focada em uma perspectiva puramente societária. Desta forma, aqueles casos em que a desconsideração da personalidade jurídica de empresas integradas em grupos é utilizada para fins de proteção de interesses constitucionalmente protegidos, tais como a proteção ao trabalhador, ao consumidor, ao meio ambiente etc., não serão escopo deste trabalho.

\subsection{Análise da jurisprudência}

A análise da jurisprudência relativa à aplicação da desconsideração da personalidade jurídica aos grupos de sociedades, para os fins deste trabalho, concentrou-se nos acórdãos (e somente acórdãos) que tratam do tema emanados pelo Superior Tribunal de Justiça (STJ) e pelo Tribunal de Justiça do Estado de São Paulo (TJSP) nos últimos cinco anos. ${ }^{1}$

Em ambos os tribunais, para identificação dos acórdãos relevantes ao presente estudo, utilizou-se como critério de busca decisões que contivessem as expressões "grupo

1 Para os acórdãos do STJ, foram consideradas as decisões proferidas entre 6 de setembro de 2010 e 6 de setembro de 2005, disponíveis para consulta no website do STJ (http://www.stj.jus.br), tendo sido a consulta realizada em 6 de setembro de 2010. Para os acórdãos do TJSP, foram consideradas as decisões proferidas entre 17 de agosto de 2010 de 2010 e 17 de agosto de 2005, disponíveis para consulta no website do TJSP (http://www.tj.sp.gov.br), tendo sido a consulta realizada em 17 de agosto de 2010. 
econômico"2 e "desconsideração". Nas linhas seguintes, apresentam-se os resultados da pesquisa realizada.

\subsubsection{A jurisprudência do STJ}

Com a pesquisa realizada de acordo com os critérios de busca indicados anteriormente, foram identificados 10 (dez) acórdãos emanados pelo STJ nos últimos cinco anos que continham as expressões "grupo econômico" e "desconsideração".

Dentre tais acórdãos, 6 (seis) deles foram excluídos desta análise por tratarem de matéria meramente processual, apesar de apresentarem em seu texto as duas expressões utilizadas como critério de busca, ou por tratarem de matéria completamente diversa daquela que ora se analisa.

Com relação aos 4 (quatro) acórdãos que restaram à análise, as conclusões são bastante interessantes.

No acórdão da Terceira Turma do STJ, na Medida Cautelar n $15.526 / \mathrm{SP}$, Relatora Min. Nancy Andrighi, julgado em 22 de setembro de 2009 (v.u.), a requerente visava a antecipação da tutela buscada em recurso especial, para suspensão de decisão que estendeu os efeitos da quebra de uma sociedade à requerente. Neste julgado, a medida cautelar foi concedida, uma vez que nas instâncias inferiores não foi devidamente demonstrado que a empresa falida e a requerente pertenciam ao mesmo grupo econômico. Nas palavras da relatora:

2 Como indicado anteriormente neste trabalho, a pesquisa concentra-se nos grupos de fato, e por isso a expressão "grupo de direito" não foi utilizada como critério de busca. Não obstante, vale destacar que se verificou que a jurisprudência não utiliza, via de regra, a expressão "grupo de fato" em suas decisões sobre o tema, mas sim a expressão "grupo econômico". Ressalte-se que a expressão "grupo de fato" é de origem doutrinária, não estando refletida em nenhum diploma legal. Acredita-se que a jurisprudência utilize sempre a expressão "grupo econômico" pois ela não só reflete, de certa forma, a realidade dos grupos de fato, como também é a expressão adotada no primeiro diploma legal do ordenamento brasileiro a se referir, de uma forma ou de outra, a este fenômeno: o art. $2^{\circ}, \S 2^{\circ}$ da CLT. Sendo assim, optou-se por realizar a busca utilizando-se apenas a expressão "grupo econômico". 
Ao permitir a extensão da falência mediante procedimento incidental, o STJ teve em mira as hipóteses em que há vínculo societário. Sem ele, não há como atingir, mediante a desconsideração, o patrimônio de terceiro alheio ao grupo econômico. A gravidade da decisão que determina extensão dos efeitos da falência de uma empresa a outra é notória. Normalmente, a falência consubstancia medida irreversível. Assim, todas as cautelas devem ser tomadas para que tal decisão somente seja tomada de maneira segura. A dúvida quanto ao grupo econômico a que pertence a SECURINVEST recomenda que, inicialmente, o seu direito seja acautelado. Até que se possa definir a que grupo econômico essa empresa pertence, entendo conveniente suspender, por ora, a falência decretada, antes que se tornem irreversíveis os danos causados à empresa.

No acórdão da Quarta Turma do STJ, no Recurso Especial n 1.071.643/DF, Relator Min. Luis Felipe Salomão, julgado em 2 de abril de 2009 (v.u.), a recorrente insurgiu-se contra decisão do tribunal de segunda instância que decretou a desconsideração da personalidade jurídica de empresa devedora em ação de execução de título judicial, para arrecadação de bens da recorrente, visto que ambas petenceriam ao mesmo grupo econômico. Embora os ministros tenham mantido a decisão do juízo a quo em razão da impossibilidade de reexaminarem matéria probatória, nos termos da Súmula $n^{\circ} 07$ do STJ, o relator frisou que "Esta Corte se manifestou em diversas ocasiões no sentido de ser possível atingir, com a desconsideração da personalidade jurídica, empresa pertencente ao mesmo grupo, quando evidente que a estrutura deste é meramente formal.". O relator cita precedente da Ministra Nancy Andrigui (Recurso Ordinário em Mandado de Segurança $\mathrm{n}^{\circ}$ 12.872/SP, Terceira Turma, Rel. Ministra Nancy Andrighi, julgado em 24 de junho de 2002 - anterior, portanto, ao período incluído no critério de pesquisa dos acórdãos analisados para fins desta dissertação) onde menciona-se na ementa:

Pertencendo a falida a grupo de sociedades sob o mesmo controle e com estrutura meramente formal, o que ocorre quando as diversas pessoas jurídicas do grupo exercem suas atividades sob unidade gerencial, laboral e patrimonial, é legitima a desconsideração da personalidade jurídica da falida para que os efeitos do decreto falencial alcancem as demais sociedades do grupo. Impedir a desconsideração da personalidade jurídica nesta hipótese implicaria prestigiar a fraude à lei ou contra credores.

No acórdão da Quinta Turma do STJ, no Recurso Especial n 968.564/RS, Relator Min. Arnaldo Esteves Lima, julgado em 18 de dezembro de 2008 (v.u.), a recorrente irresigna-se com decisão proferida pelo juízo de segundo grau que negou a 
desconsideração da personalidade jurídica de empresa devedora, para arrecadação de bens de sua controladora. $\mathrm{O}$ recurso especial foi improvido, com a seguinte fundamentação:

\begin{abstract}
Com efeito, a desconsideração da pessoa jurídica, mesmo no caso de grupos econômicos, deve ser reconhecida em situações excepcionais, quando verificado que a empresa devedora pertence a grupo de sociedades sob o mesmo controle e com estrutura meramente formal, o que ocorre quando diversas pessoas jurídicas do grupo exercem suas atividades sob unidade gerencial, laboral e patrimonial, e, ainda, se visualizar a confusão de patrimônio, fraudes, abuso de direito e má-fé com prejuízo a credores. Da mesma forma, nos termos dos arts. 116, 117 e 246 da Lei das Sociedades Anônimas, somente imputa-se à empresa controladora a obrigação de arcar com as dívidas contraídas pela empresa controlada quando decorrentes de danos causados por atos praticados com abuso de poder. $\mathrm{Na}$ hipótese dos autos, contudo, tendo o Tribunal de origem, com base no conjunto probatório dos autos, firmado a compreensão no sentido de que não restaria demonstrada a má administração ou prática de ato fraudulento pela executada, rever tal entendimento importaria incursão na seara fático-probatória, o que atrai o óbice da Súmula 7/STJ.
\end{abstract}

Nos casos descritos acima, nota-se que as decisões sobre a desconsideração ou não da personalidade jurídica de sociedades integrantes de grupos societários geralmente respeita a decisão do tribunal a quo em vista da Súmula $n^{\circ} 7$ do STJ, que veda o reexame, pelo STJ, de matéria fático-probatória. Não obstante, nota-se também que os casos versam sobre credores que, em dificuldade de reaver seus créditos (em ações de execução ou em processos falimentares), tentam recorrer à desconsideração da personalidade jurídica para arrecadar bens de outras empresas integrantes do mesmo grupo econômico da falida/executada, tudo na tentativa de satisfazer sua pretensão.

Embora os julgados acima tenham demonstrado certa cautela do STJ no que diz respeito à desconsideração da personalidade jurídica, visto ser uma decisão extremamente gravosa para as sociedades envolvidas, chama-se a atenção para o precedente de relatoria da Ministra Nancy Andrighi mencionado.

Este precedente é citado na maioria dos julgados do TJSP nos quais a desconsideração da personalidade jurídica de empresas pertencentes a grupos de sociedades foi deferida (vide análise detalhada no próximo tópico). O problema deste precedente é que nele foi inserida uma "definição" de grupos de sociedades que não existe na LSA: o grupo de sociedades sob o mesmo controle e com estrutura meramente formal 
ocorre quando as diversas pessoas jurídicas do grupo exercem suas atividades sob unidade gerencial, laboral e patrimonial.

Como visto, a direção unitária é elemento caracterizador dos grupos de sociedades, embora tal conceito não seja previsto na LSA. Existindo uma direção unitária na realidade fática dos grupos, é esperado que exista unidade gerencial, laboral e patrimonial entre as sociedades que o integram. Esta unidade, contudo, não é, de pronto, ensejadora de confusão patrimonial, abuso de direito ou fraude a credores (embora isso possa ocorrer na prática e, neste caso, o abuso deve sim ser reprimido). Ela é inerente à figura dos grupos.

Como se verá adiante, especialmente quando da análise dos acórdãos do TJSP, a desconsideração da personalidade jurídica de sociedades integrantes de grupos vem sendo utilizada para dar guarida à proteção de credores, mas os fundamentos desta desconsideração parecem equivocados. O que se argumenta como fundamento para a desconsideração não é evidência de abuso, fraude ou outro dos requisitos do art. 50 do Código Civil, mas sim elemento essencial da figura dos grupos. Como a regulamentação dos grupos, como visto, não é precisa em regulamentar o fenômeno e proteger todos os interesses envolvidos, a desconsideração da personalidade jurídica acaba sendo utilizada como uma "válvula de escape". É como se os juízes tivessem encontrado uma forma de fazer justiça, quando a aplicação da lei não é capaz de fazê-lo.

Um único acórdão do STJ, incluído em nossa análise, sustentou que a desconsideração da personalidade jurídica em sociedades integrantes de grupos de sociedade somente pode ser decretada quando houver abuso de direito, excesso de poder, infração à lei, fato ou ato ilícito ou violação dos estatutos ou contrato social, por ser medida excepcional. Para o relator deste caso, amparado em doutrina, a desconsideração não deve ser utilizada como instrumento de investigação dos fatos; há de se comprovar o abuso (STJ, Recurso Especial n ${ }^{\circ} 744.107 / S P$, Rel. Min. Fernando Gonçalves, Quarta Turma, julg. 20.05.2008, v.u.). 


\subsubsection{A jurisprudência do TJSP}

Com a pesquisa realizada de acordo com os critérios de busca indicados acima, foram identificados 540 (quinhentos e quarenta) acórdãos emanados pelo TJSP nos últimos cinco anos que continham as expressões "grupo econômico" e "desconsideração".

Dentre eles, 325 (trezentos e vinte e cinco) acórdãos foram excluídos desta análise devido a quatro critérios distintos: (i) por tratarem de matéria de direito público, que foge ao escopo desta dissertação; (ii) por tratarem da desconsideração da personalidade jurídica em grupos societários com base em um dos dispositivos legais citados nos itens 3.4.1 a 3.4.5 do Capítulo 3 deste trabalho, e que por isso fogem à perspectiva societária que ora se analisa $^{3}$; (iii) por tratarem de matéria meramente processual, apesar de apresentarem em seu texto as duas expressões utilizadas como critério de busca; e (iv) por tratarem de matéria completamente diversa daquela que ora se analisa, apesar de apresentarem em seu texto as duas expressões utilizadas como critério de busca.

Consideradas as exclusões identificadas acima, restaram a esta análise 214 (duzentos e quatorze) acórdãos do TJSP nos quais se trata especificamente da desconsideração da personalidade jurídica nos grupos de sociedades.

Apesar do elevado número de decisões relevantes identificadas, os casos são altamente semelhantes. Em todos os casos relevantes analisados, a matéria discutida é uniforme: trata-se de credor que, em vista da impossibilidade de satisfação de seu crédito, requereu a desconsideração da personalidade jurídica do devedor, integrante de grupo econômico, para que outras empresas do grupo integrem o pólo passivo da lide, na tentativa de satisfação do crédito.

A solução encontrada pelos magistrados em todos os casos analisados segue duas linhas argumentativas bastante claras e distintas, como se verá a seguir.

3 Como ensina Blumberg: "[...] cases arising in different areas of the law require analysis in terms of the underlying policies of the area under consideration. The indiscriminate application of 'piercing the veil jurisprudence' as a universal concept has been one of its most serious limitations. ” (BLUMBERG, 1987, p. 136). 
Em 80 (oitenta) acórdãos, os magistrados sustentaram que a desconsideração da personalidade jurídica de uma sociedade pertencente a um grupo econômico só pode ser determinada se presentes os requisitos que autorizam a aplicação da medida, tal como determinados pelo art. 50 do Código Civil, isto é, a confusão patrimonial, a fraude a lei ou o abuso de direito ${ }^{4}$.

Nesses julgados, os magistrados sustentam, em suma: (i) que a mera participação de um sócio em mais de uma empresa não configura grupo econômico; e (ii) que a existência de grupo econômico não implica necessariamente em confusão patrimonial, fraude à lei ou abuso de direito. $\mathrm{O}$ abuso de direito, a confusão patrimonial e a eventual tentativa de fraudar credores sob o "escudo" da pessoa jurídica deve ser demonstrado. Os principais argumentos empregados nestes acórdãos são exemplificados abaixo.

No acórdão da $18^{\mathrm{a}}$ Câmara de Direito Privado do TJSP, no Agravo de Instrumento $\mathrm{n}^{\circ}$ 991.09.054380-8, Relator Alexandre Lazzarini, julgado em 25 de maio de 2010 (v.u.), os desembargadores entenderam que a mera inatividade da empresa não enseja a desconsideração da personalidade jurídica se não demonstrados os requisitos descritos no art. 50 do Código Civil. Menciona o relator em seu voto:

O fato de não saber sobre a existência de bens, haveres hábeis a suportar a execução e, até mesmo, a inatividade da empresa não configuram de pronto, o preenchimento dos requisitos já apontados do art. 50 do Código Civil, assim como, a insolvência da agravada não autoriza a invasão no patrimônio pessoal dos sócios, sem a comprovação de fraude na administração da sociedade.

O que fica demonstrado neste acórdão é que, na opinião dos desembargadores, a mera dificuldade de satisfação do crédito não enseja, de pronto, a desconsideração da personalidade jurídica dos grupos de sociedade. Há que se demonstrar a fraude à lei, a confusão patrimonial ou o abuso de direito, tendo diversas outras decisões no mesmo

4 A relação completa dos acórdãos relevantes nos quais decidiu-se pela não aplicação da desconsideração da personalidade jurídica aos grupos de sociedades encontra-se nas referências deste trabalho. 
sentido sido encontradas na pesquisa. ${ }^{5}$

Outro argumento bastante recorrente nos julgados em que a desconsideração da personalidade jurídica dos grupos de sociedade foi afastada é o de que a simples condição de sócio de mais de uma empresa não implica, necessariamente, na existência de um grupo econômico e, portanto, não enseja de imediato a desconsideração.

No acórdão da $23^{\text {a }}$ Câmara de Direito Privado do TJSP, no Agravo de Instrumento n 9 990.10.067054-9, Relator Elmano de Oliveira, julgado em 9 de junho de 2010 (v.u.), os desembargadores sustentaram que:

[...] [i]nicialmente, cumpre ressaltar que a simples condição de sócio da sociedade executada, não autoriza a inclusão automática deste no pólo passivo da execução, eis que o mesmo não participou da relação negocial que deu origem ao crédito exeqüendo. Por conseqüência, é inadmissível que a execução recaia prematuramente sobre os seus bens, pois, caso contrário, haveria indevida aplicação extensiva do instituto da desconsideração da personalidade jurídica, sem que os requisitos e pressupostos necessários para sua incidência estivessem presentes. [...] No caso em apreço, o agravante consubstancia seu pedido de inclusão de terceira empresa, sócia da sociedade executada, em meras conjecturas acerca de suposto abuso da personalidade jurídica desta, sem, contudo, demonstrar concretamente a sua ocorrência, a teor do que dispõe o art. 50 do Código Civil.

No mesmo sentido, vale destacar trecho de outro julgado analisado durante a pesquisa:

O fato de as agravantes terem sido reconhecidas como integrantes de um grupo econômico para fins de dissídio coletivo perante a Justiça do Trabalho não induz

5 Tais como, entre outros menos recentes: TJSP, Agravo de Instrumento n ${ }^{\circ}$ 990.09.276489-6, Rel. Emanuel Oliveira, 27 $7^{\mathrm{a}}$ Câmara de Direito Privado, julg. 19.01.2010, v.u.; TJSP, Agravo de Instrumento $\mathrm{n}^{\circ}$ 992.08.061282-1, Rel. Francisco Thomaz, 29a Câmara de Direito Privado, julg. 21.10.2009, v.u.; TJSP, Agravo de Instrumento no 992.09.067007-7, Rel. José Malerbi, 35 a Câmara de Direito Privado, julg. 19.10.2009, v.u.; TJSP, Agravo de Instrumento no 650.416-4/9-00, Rel. Ribeiro da Silva, $8^{\text {a }}$ Câmara de Direito Privado, julg. 16.09.2009, v.u; TJSP, Agravo de Instrumento $\mathrm{n}^{\circ}$ 1.226.133-0/8, Rel. César Lacerda, 28 ${ }^{\mathrm{a}}$ Câmara de Direito Privado, julg. 28.07.2009, v.u.; TJSP, Agravo de Instrumento $\mathrm{n}^{\circ}$ 541.712.4/0-00, Rel. Francisco Loureiro, 4 ${ }^{\mathrm{a}}$ Câmara de Direito Privado, julg. 19.06.2008, v.u.; TJSP, Agravo de Instrumento $\mathrm{n}^{\mathrm{o}}$ 7228586-4, Rel. Térsio Negrato, 17 Câmara de Direito Privado, julg. 07.05.2008, v.u.; TJSP, Agravo de Instrumento 7207355-9, Rel. Ricardo Negrão, 19ª Câmara de Direito Privado, julg. 15.04.2008, v.u.; TJSP, Agravo de Instrumento $\mathrm{n}^{\mathrm{o}}$ 7188797-3, Rel. Campos Mello, 22a Câmara de Direito Privado, julg. 29.01.2008, v.u.; e TJSP, Agravo de Instrumento no 1136321-0/7, Rel. Andrade Neto, $30^{\mathrm{a}}$ Câmara de Direito Privado, julg. 19.12.2007, v.u.; todos disponíveis em: <http://www.tj.sp.gov.br>. Acesso em: 17 ago. 2010. 
na esfera cível qualquer solidariedade entre elas. Assim, sua inclusão no processo somente poderia decorrer da desconsideração da personalidade jurídica. Mas não vejo presentes seus requisitos. Como participam de um grupo econômico não impressiona a circunstância de algumas terem sócios comuns ou endereço na mesma rua. [...] Em conclusão, o simples insucesso da execução não autoriza a desconsideração da personalidade jurídica e nem o fato de terem as empresas sócios comuns ou integrarem grupo econômico implica solidariedade, se não se encontram presentes os requisitos específicos que autorizam a desconsideração. (TJSP, Agravo de Instrumento $\mathrm{n}^{\circ}$ 990.09.313847-6, Rel. Eduardo Sá Pinto Sandeville, 28 a Câmara de Direito Privado, julg. 16.03.2010, v.u. Disponível em: 〈http://www.tj.sp.gov.br>. Acesso em: 17 ago. 2010). ${ }^{6}$

Não obstante as decisões mencionadas nos parágrafos acima, em 134 (cento e trinta e quatro) acórdãos - quase dois terços dos casos relevantes, portanto - os magistrados autorizaram a desconsideração da personalidade jurídica de empresa integrante de grupo econômico. ${ }^{7} \mathrm{O}$ fundamento da decisão, muitas vezes, parece ser simplesmente a impossibilidade de satisfação do crédito pela empresa originalmente demandada, já que, na maior parte dessas decisões, os magistrados sustentaram que a mera existência de grupo econômico implica quase que automaticamente em confusão patrimonial, autorizando a desconsideração.

No acórdão da $21^{\mathrm{a}}$ Câmara de Direito Privado, no Agravo de Instrumento $\mathrm{n}^{\mathrm{o}}$ 990.09.300306-6, Relator Itamar Gaino, julgado em 9 de junho de 2010 (v.u.), os desembargadores sustentaram ser "inegável a possibilidade de serem desconsideradas as personalidades jurídicas de empresas que façam parte de um mesmo conglomerado ou grupo econômico, sendo muitas vezes geridas pela mesma administração; isso a fim de impedir a elisão de responsabilidades.”. Contudo, vale mencionar que nesta decisão os

6 No mesmo sentido (de que o mero fato de ter sócios comuns não implica necessariamente na existência de grupo econômico e/ou não enseja de pronto a desconsideração da personalidade jurídica), vide: TJSP, Agravo de Instrumento no 992.08.067709-5, Rel. Luiz Felipe Nogueira, 30a Câmara de Direito Privado, julg. 16.09.2009, v.u.; TJSP, Apelação com Revisão no 973565-0/7, Rel. Francisco Casconi, $31^{\text {a }}$ Câmara de Direito Privado, julg. 04.08.2009, v.u.; TJSP, Agravo de Instrumento no 7293295-9, Rel. Térsio Negrato, $17^{\mathrm{a}}$ Câmara de Direito Privado, julg. 15.12.2008, v.u.; TJSP, Agravo de Instrumento $\mathrm{n}^{\circ}$ 7.268.820-3, Rel. José Marcos Marrone, 23 ${ }^{\mathrm{a}}$ Câmara de Direito Privado, julg. 10.09.2008, v.u.; TJSP, Agravo de Instrumento $\mathrm{n}^{\mathrm{o}}$ 7179335-4, Rel. Gilberto dos Santos, $11^{\mathrm{a}}$ Câmara de Direito Privado, julg. 08.11.2007, v.u.; TJSP, Agravo de Instrumento n ${ }^{\circ}$ 7140710-2, Rel. Campos Mello, 22 $2^{\text {a }}$ Câmara de Direito Privado, julg. 15.05.2007, v.u.; TJSP, Agravo de Instrumento $\mathrm{n}^{\mathrm{o}}$ 7131934-3, Rel Campos Mello, 22a Câmara de Direito Privado, julg. 24.04.2007, v.u.; TJSP, Agravo de Instrumento no 451.527.4/4-00, Rel. Francisco Loureiro, $4^{\mathrm{a}}$ Câmara de Direito privado, julg. 19.10.2006, v.u.; e TJSP, Apelação no 1.271821 9, Rel. Waldir de Souza José, $5^{\text {a }}$ Câmara de Direito Privado, julg. 22.08.2006, v.u.; todos disponíveis em: <http://www.tj.sp.gov.br>. Acesso em: 17 ago. 2010. A idéia de que a existência de sócios comuns é inerente aos grupos e que por isso não implica, necessariamente, em desconsideração da personalidade jurídica, aparece também em muitos dos acórdãos citados na nota de rodapé $\mathrm{n}^{\circ} 5$, deste capítulo.

7 A relação completa dos acórdãos relevantes nos quais decidiu-se pela aplicação da desconsideração da personalidade jurídica aos grupos de sociedades encontra-se nas referências deste trabalho. 
desembargadores salientam que a mera realização de negócios comuns ou a existência de sócios coincidentes em diversas sociedades não caracterizam o grupo econômico. O reconhecimento da existência do último resulta "por estar patenteado que as pessoas naturais e jurídicas unem seus esforços para a realização, de forma permanente, de diversos negócios, estando, portanto, vinculadas juridicamente entre si, com o estabelecimento de organização hierárquica e de dependência econômica."

Neste julgado, nota-se que a desconsideração da personalidade jurídica dos grupos societários foi autorizada, mas houve certa preocupação do magistrado em, de alguma forma, "qualificar" o grupo de sociedades. Não é, entretanto, o que acontece na maioria das decisões analisadas.

Cite-se o caso do acórdão da $37^{\mathrm{a}}$ Câmara de Direito Privado no Agravo de Instrumento $\mathrm{n}^{\text {o }}$ 991.09.041164-2, Relator Eduardo Siqueira, julgado em 3 de março de 2010 (v.u.). Trata-se de agravo de instrumento interposto em ação de execução de título extrajudicial onde a agravante pleiteou a inclusão de sociedade integrante do mesmo grupo econômico da agravada no pólo passivo da execução. Segundo o voto do relator, a agravada e a outra empresa que se pretendia incluir no pólo passivo da execução tinham os mesmos sócios, o mesmo endereço e o mesmo objeto social. Com base nestas informações, o desembargador concluiu ser:

[...] de clareza solar a confusão patrimonial e societária de ambas e patente a sucessão empresarial, o que autoriza a aplicação da desconsideração da personalidade jurídica, para que a empresa NOVO HORIZONTE RECURSOS HUMANOS seja incluída no pólo passivo da presente execução, com base no art. 50 do Código Civil.

Mas coincidência de endereço, objeto e sócios apenas evidencia confusão patrimonial com "clareza solar"?

Retoma-se aqui o precedente do STJ de relatoria da Ministra Nancy Andrigui mencionado quando da análise dos acórdãos daquela corte. Nele, menciona-se que o grupo tem estrutura meramente formal quando as empresas que o integram exercem suas atividades sob unidade gerencial, laboral e patrimonial, e que, nesses casos, a não desconsideração da personalidade jurídica implicaria em possível fraude a seus credores. 
Esse precedente é citado em boa parte dos acórdãos do TJSP nos quais a desconsideração da personalidade jurídica de empresa integrante de grupo societário foi deferida (e quando o precedente não é citado expressamente, a fundamentação é em todo semelhante). Parece que aqui existe uma confusão de conceitos. Se o grupo realmente tiver uma estrutura meramente formal, criada com o intuito de fraudar credores, não resta dúvida que há fraude, abuso de direito e outros requisitos autorizadores da aplicação da desconsideração da personalidade jurídica, nos termos do art. 50 do Código Civil.

No entanto, nem todo grupo é criado para fins fraudulentos. Grupos societários são um mecanismo de organização da atividade empresarial válidos e permitidos pelo ordenamento pátrio. E se, como visto, a principal característica dos grupos de fato é a direção unitária, natural que as empresas do grupo atuem sob "unidade gerencial, laboral e patrimonial". A intenção de proteger os credores é louvável, mas a fundamentação empregada não parece de todo convincente.

Semelhante, o caso narrado no acórdão preferido pela $11^{\mathrm{a}}$ Câmara de Direito Privado no Agravo de Instrumento $n^{\circ}$ 990.09.306575-4, Relator Soares Levada, julgado em 21 de janeiro de 2010 (v.u.). Nele, sustentou o relator estar demonstrado que:

[...] as empresas coincidem quanto ao ramo de atividade, endereço e que já coincidiram quanto ao quadro societário e, mesmo com empenho do exeqüente, não se consegue obter resultado prático algum, sem êxito nas tentativas de localização e penhora de outros bens para satisfazer o credor exeqüente. [...] $\mathrm{Na}$ contraminuta, foi juntado extrato do Tribunal de Justiça (fl. 201/202) dando conta de quase cinqüenta ações ajuizadas contra a empresa agravante - em sua maioria execuções e monitórias - dando força à tese do agravado de que a empresa Alaíde Automóveis Ltda. seria devedora contumaz. Assim, e em suma, quem desenvolve irregularmente suas atividades, com confusão patrimonial, desvio e abuso da pessoa jurídica, com dívida já constituída, sem provisão de bens para garantir a integral quitação dos débitos, dá azo à aplicação da 'disregard', pois nítido o propósito fraudulento da conduta [...].

Coincidência de endereço, atividade e quadro societário, aliado a existência de diversas execuções e monitórias ajuizadas contra a empresa, por si só, são capazes de demonstrar, com nitidez, a confusão patrimonial e o propósito fraudulento da conduta? ${ }^{8}$

8 Em que pese o fato de, em muitos casos, os julgados apresentarem indícios de que realmente houve intenção de fraudar credores por meio de artifícios societários empregados pelos grupos de sociedades, na 
Importante destacar, também, os casos em que a desconsideração da personalidade jurídica de empresas integrantes de grupos de sociedades foi declarada com intuito de estender efeitos da falência a outras empresas integrantes do grupo da falida.

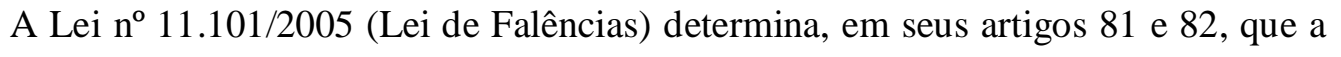
decretação da falência de uma sociedade acarreta a falência dos sócios da falida que tenham responsabilidade ilimitada, sujeitando-os aos mesmos efeitos jurídicos produzidos com relação à sociedade falida. Com relação às sociedades com sócios de responsabilidade limitada, a Lei de Falências determina que a responsabilidade dos sócios, controladores e administradores, estabelecidas nas leis que regulamentam os respectivos tipos jurídicos, será apurada no juízo da falência, podendo o juiz determinar a indisponibilidade de bens particulares dos réus até o final do julgamento da ação da responsabilização.

Conclui-se, dos dispositivos citados acima, que a Lei de Falências não prevê a extensão de efeitos da falência a sócios da falida que possuam responsabilidade limitada. Nas sociedades anônimas, foco desta dissertação, a apuração de responsabilidade dos sócios, controladores e administradores é realizada conforme previsto nos artigos 115, 117, 158 e 159 da LSA.

A jurisprudência mostra uma realidade distinta. A pesquisa realizada mostrou recorrentes casos em que foi decretada a desconsideração da personalidade jurídica de

maioria dos casos analisados a decisão dos magistrados parece demonstrar certa carência de fundamento. Elementos considerados como indícios de confusão patrimonial ou fraude contra credores, como a coincidência de sócios, endereço e atividades entre as empresas do grupo, não parecem ser suficientes para, por si só, caracterizar o preenchimento dos requisitos determinados no art. 50 do Código Civil para a desconsideração da personalidade jurídica. Esta questão será retomada mais adiante, mas pode-se citar como exemplos destes casos: TJSP, Apelação no 992.06.011239-4, Rel. Júlio Vidal, $28^{\text {a }}$ Câmara de Direito Privado, julg. 15.12.2009, v.u.; TJSP, Agravo de Instrumento $\mathrm{n}^{\circ}$ 1278814-0/0, Rel. Gomes Varjão, 34a Câmara de Direito Privado, julg. 17.08.2009, v.u.; TJSP, Agravo de Instrumento nº 620.6954/6, Rel. Maia da Cunha, 4a Câmara de Direito Privado, julg. 03.09.2009, v.u.; TJSP, Agravo de Instrumento no 1258245-0/0, Rel. José Malerbi, 35 a Câmara de Direito Privado, julg. 20.07.2009, v.u.; TJSP Agravo de Instrumento no 1240323-0/1, Rel. Melo Bueno, 35 a Câmara de Direito Privado, julg. 30.03.2009, v.u.; TJSP, Apelação Cível com Revisão no 516.507-4/6-00, Rel. Jesus Lofrano, $3^{\mathrm{a}}$ Câmara de Direito Privado, julg. 17.03.2009, v.u.; TJSP, Apelação com Revisão n ${ }^{\circ}$ 1234947-0/6, Rel. Artur Marques, 35 ${ }^{\mathrm{a}}$ Câmara de Direito Privado, julg. 02.02.2009, v.u.; TJSP, Agravo de Instrumento $\mathrm{n}^{\circ}$ 7293250-0, Rel. Luiz Sabbato, 13 ${ }^{a}$ Câmara de Direito Privado, julg. 19.11.2008, v.u.; TJSP, Agravo de Instrumento $\mathrm{n}^{\mathrm{o}}$ 1229723-0/6, Rel. Ricardo Pessoa de Mello Belli, 25 Câmara de Direito Privado, julg. 02.12.2008, v.u.; e TJSP, Agravo de Instrumento n $\mathrm{n}^{\mathrm{0}}$ 7.284.496-7, Rel. Ribeiro de Souza, 12 ${ }^{\mathrm{a}}$ Câmara de Direito Privado, julg. 17.09.2008, v.u.; todos disponíveis em: <http://www.tj.sp.gov.br>. Acesso em: 17 ago. 2010. 
empresa falida, integrante de grupo societário, e desta decisão decorreu a extensão dos efeitos da falência às demais empresas integrantes do grupo. ${ }^{9}$

É esta a situação descrita no acórdão preferido pela $1^{\text {a }}$ Câmara de Direito Privado, no Agravo de Instrumento 587.310-4/1-00, Relator Elliot Akel, julgado em 2 de junho de 2009 (v.u.). Para o desembargador relator, seriam irretorquíveis as considerações tecidas pelo síndico da falência e seu relatório:

\begin{abstract}
A transferência de bens da sociedade para outrem, às vésperas da quebra ou durante o período do termo legal, é conduta reprovável nas relações de comércio, causadora da insolvência. Tal conduta justifica a desconsideração da personalidade jurídica e a declaração de ineficácia de qualquer ato lesivo levado a efeito, bem como qualquer transferência de bens ou patrimônio da empresa, determinando extensão dos efeitos da falência às pessoas dos controladores e a outras empresas por eles controladas, ainda que administradas por terceiros. A aplicação da desconsideração da personalidade jurídica das controladas, (sic) justifica-se porque está demonstrado que elas foram criadas ao longo dos anos para a descapitalização da falida. Com evidência, houve mau uso da personalidade jurídica, que só poderá ser medida se desconsiderada, a até mesmo do ponto de vista tributário em que a falida se serviu das empresas controladas como melhor lhe aprouvera.
\end{abstract}

No caso descrito acima, em que pese a possibilidade de sociedades integrantes do grupo societário terem realizado operações com o intuito de desviar bens da falida, note-se que foi mencionado que os atos foram praticados "às vésperas da quebra ou durante o período do termo legal". A Lei de Falências já prevê solução para estes casos. Os artigos

9 Vide BARBI FILHO, Celso. Ilegalidade da arrecadação dos bens da sociedade controlada na falência de sua controladora. RDM, n. 116, p. 211-214, out./dez. 1999. Neste parecer o autor sustenta a ilegalidade da arrecadação de bens da sociedade controlada ocorrida na falência de sua controladora. Em que pese o fato de este parecer ter sido emanado quando da vigência da anterior lei de falências (Decreto-Lei n7.661/45), a discussão é bastante semelhante. Destaque para a observação de que tendo em vista a falência da sócia controladora, a continuação da sociedade controlada tornava-se inviável na prática. Em vista disso, a sociedade controlada rumava para a dissolução. Essa dissolução, contudo, se daria por razões fáticas e não jurídicas, o que não permitiria que o procedimento dissolutório da controlada fosse considerado mero incidente no curso da falência de sua controladora, com arrecadação dos bens da primeira. De maneira semelhante, em parecer de 1992, Leães proferiu a seguinte opinião a respeito de decisão que determinou, por meio da desconsideração da personalidade jurídica, a arrecadação de todos os bens de sociedade falida existentes em sociedades por ela controlada: "Com efeito, a teoria da desconsideração autoriza a suspensão tópica e temporária da eficácia do ato jurídico de constituição da sociedade, a fim de que se possa, levantando o véu da pessoa jurídica, atribuir aos sócios responsabilidade subsidiária por dívidas da sociedades, ou vice-versa. Na hipótese, porém, ao determinar a arrecadação dos bens 'correspondentes ao patrimônio das empresas controladas e coligadas' da empresa C. (sob pretexto de que seriam já 'bens da falida existentes em tais empresas'), o ilustre magistrado, mais do que determinar a suspensão episódica do ato constitutivo do ente moral, para fins de responsabilidade, está na verdade decretando a inexistência ou invalidade da autonomia patrimonial das pessoas jurídicas envolvidas." (LEÃES, Luiz Gastão Paes de Barros. Desconsideração da Personalidade Jurídica. In: Pareceres. São Paulo: Singular, 2004. p.

371-384, p. 380-381) 
129 e 130 desta lei determinam casos de ineficácia e revogação de atos praticados em prejuízo de credores da massa falida. Sendo assim, caso houvesse, de fato, intenção de fraudar credores da massa nas operações realizadas pelo grupo, a solução estaria na própria Lei de Falências.

A solução adotada pelo tribunal paulista acarreta conseqüências muito mais gravosas. Se adotada a solução prevista na Lei de Falências, apenas o ato praticado em detrimento dos credores seria declarado ineficaz ou revogado. Com a decretação da desconsideração da personalidade jurídica da falida e extensão dos efeitos da falência às demais empresas do grupo, não há apenas revogação ou ineficácia de atos isolados, mas sim arrecadação de todos os bens das empresas integrantes do grupo. A "proteção" conferida aos credores quando se adota esta solução é muito maior e, por isso, pode-se afirmar que, assim como nos casos de execuções descritos acima, trata-se de uma prática jurisprudencial adotada para aumentar as chances dos credores da massa falida de terem seus créditos satisfeitos. ${ }^{10}$

\subsection{Análise da aplicação jurisprudencial, em uma perspectiva societária, da desconsideração da personalidade jurídica nos grupos de sociedades}

Como visto nos casos da jurisprudência apresentados anteriormente, o principal foco de aplicação da desconsideração da personalidade jurídica nos grupos de sociedades,

10 Para outros casos de desconsideração da personalidade jurídica da falida para extensão dos efeitos da falência às outras empresas integrantes de seu grupo econômico, vide: TJSP, Agravo de Instrumento ${ }^{\circ}$ 569.212-4/2-00, Rel., Elliot Akel, $1^{\text {a }}$ Câmara de Direito Privado, julg. 03.03.2009, v.u.; TJSP, Agravo de Instrumento $\mathrm{n}^{\mathrm{o}}$ 573.248-4/0-00, Rel. Elliot Akel, $1^{\mathrm{a}}$ Câmara de Direito Privado, julg. 03.02.2009, v.u.; TJSP, Agravo de Instrumento $n^{\circ}$ 584.750-4/7-00, Rel. Pereira Calças, Câmara Especial de Falências e Recuperações de Direito Privado, julg. 29.10.2008, v.u.; TJSP, Agravo de Instrumento no 557.843-4/9-00, Rel. Elliot Akel, $1^{\text {a }}$ Câmara de Direito Privado, julg. 14.10.2008, v.u.; TJSP, Agravo de Instrumento ${ }^{\circ}$ 531.742-4/8-00, Rel. Elliot Akel, $1^{\text {a }}$ Câmara de Direito Privado, julg. 30.09.2008, v.u.; TJSP, Agravo de Instrumento $\mathrm{n}^{\mathrm{o}}$ 532.684-4/0-00, Rel. Elliot Akel, 1 a Câmara de Direito Privado, julg. 30.09.2008, v.u.; TJSP, Apelação Cível com Revisão no 509.001-4/0-00, Rel. Salles Rossi, $8^{\text {a }}$ Câmara de Direito Privado, julg. 17.09.2008, v.u.; TJSP, Agravo de Instrumento no 521.791-4/2-00, Rel. Romeu Ricupero, Câmara Especial de Falências e Recuperações Judiciais de Direito Privado, julg. 27.08.2008, v.m. (vide voto vencido de Lino Machado); TJSP, Agravo de Instrumento no 563.612-4/4-00, Rel. Pereira Calças, Câmara Especial de Falências e Recuperações Judiciais de Direito Privado, julg. 27.08.2008, v.u.; e TJSP, Agravo de Instrumento no 497.422-4/1-00, Rel. Romeu Ricupero, Câmara Especial de Falências e Recuperações Judiciais de Direito Privado, julg. 29.08.2007, v.u.; todos disponíveis em: 〈http://www.tj.sp.gov.br>. Acesso em: 17 ago. 2010. 
em uma perspectiva societária, diz respeito a problemas relacionados à proteção de credores. A seguir, uma análise mais detalhada deste aspecto.

\subsubsection{O problema da proteção dos credores}

As regras previstas na LSA para regulamentar as relações estabelecidas entre as sociedades integrantes de um grupo de fato partem de uma premissa de independência entre as sociedades grupadas. Conforme Teixeira e Guerreiro:

Nem mesmo quando se convencione, o grupo de sociedades perde sua individualidade às componentes do grupo. Isso porque a vinculação societária, por mais profunda que seja, não tem o condão de afastar, per si, a incidência do princípio fundamental segundo o qual a pessoa jurídica está rigorosamente separada da personalidade de seus membros. ${ }^{11}$

Nos grupos de fato, inexistindo a convenção grupal que autorizaria a subordinação do interesse das sociedades controladas ao interesse da sociedade controladora ${ }^{12}$, o interesse das sociedades controladas não pode - em teoria - subordinar-se aos interesses das demais sociedades do grupo ${ }^{13} \mathrm{e}$, em vista disso, não há nenhuma regra especial de

11 TEIXEIRA; GUERREIRO, 1979, p. 704. No mesmo sentido: “En principe, la société-mère ne souffre aucune responsabilité du fait de ses filiales et vice versa; les différentes composantes d'um groupe ont une personnalité juridique distincte, qui interdit de tenir l'une pour responsable raison du comportement des autres." (COZIAN, Maurice; VIANDIER, Alain; DEBOISSY, Florence. Droit des Sociétés. 21. ed. Paris: LexisNexis, 2008, p. 661). Estes autores indicam, na página 662 da mesma obra, que o princípio sofre algumas exceções, como no caso de confusão patrimonial entre as sociedades do grupo, especialmente na falência da controlada. Acompanha a opinião Roger Houin: "En principe, la sociétémère n'est pas tenue des detter de as filiale, car il s'agit de deux personnes morales et de deux patrimoines distincts. Mais la solution est inverse si la filiale a une personalité morale fictive, par exemple si tout son capital est entre les mains de la société-mére ou si elle a été constituée dans un but de fraude; la solution est encore inverse lorsqu'il existe une confusion totale des activités et des patrimoines des deux sociétés du groupe et si celles-ci apparaissent comme une société unique. Ces solutions sont principalemente relevées lorsque la filiale est mise en faillite: la faillite pourra être "étendue" a la société-mère (et plus généralemente a toutes les sociétés d'un groupe); elle pourra aussi être étendue de la filiale à la société-mère lorsque celle-ci dirigé en fait ou en droit la première et a abusé des actifs sociaux de la filiale dans son intérêt propre ou dans l'intérêt du groupe." (HOUIN, 1982, p. 54).

12 Nos termos dos arts. 265 e 266 da LSA.

13 "O interesse particular da sociedade controlada não se submete, portanto, a nenhum outro interesse, a não ser o interesse nacional. As conveniências da controladora e bem assim de qualquer outra sociedade vinculada não preponderam, conseqüentemente sobre o interesse particular da sociedade controlada, a qual mantém, por assim dizer, absoluta autonomia de objetivos, devendo seus administradores exercer as atribuições que a lei e o estatuto lhe conferem para lograr os fins e no interesse da companhia, satisfeitas, apenas, as exigências do bem público e da função social da empresa (art. 154, caput)." (TEIXEIRA; GUERREIRO, op. cit., p. 698). 
proteção para os credores das sociedades integrantes de grupos de fato; aplicam-se as regras de proteção aos credores das sociedades individualmente consideradas.

O problema é que esta independência entre as sociedades integrantes dos grupos de fato na realidade não existe. O que se verifica, na maioria dos casos, é a existência de uma unidade econômica (em maior ou menor grau, é verdade), entre as empresas integrantes dos grupos de fato, e o estabelecimento de uma política global a ser observada por todas elas, estabelecida pela controladora. Essa política global, vindo "de cima para baixo", quase sempre resulta em algum grau de subordinação dos interesses das sociedades controladas ao interesse do grupo ${ }^{14}$, embora esta realidade não seja considerada pela LSA. $^{15}$

Tanto isso é verdade que em todos os julgados analisados acima verifica-se notoriamente, como observado por Prado, que embora a disciplina dos grupos de fato cuide apenas da relação entre as sociedades controladora e controladas, a jurisprudência trata da unidade do grupo empresarial para fins de imputação da responsabilidade a quem detém o comando. Nas palavras da autora, a jurisprudência "cuida do grupo na sua patologia, mas não na sua fisiologia e levando em conta a organização empresarial interna". ${ }^{16}$

Isso porque a unidade existente no grupo empresarial pode dar margem a prejuízos irreparáveis para os credores das sociedades controladas do grupo. Embora a LSA determine que eventuais prejuízos causados às sociedades controladas devam ser compensados, na prática essa compensação é difícil de apurar e mesmo de ser exigida. ${ }^{17} \mathrm{O}$ resultado é uma diminuição patrimonial na sociedade controlada, que prejudica diretamente o credor, visto ser o patrimônio da controlada a garantia de seu crédito.

14 Vide comentários a respeito do interesse do grupo no Capítulo 2, item 2.2.2.6 desta dissertação.

15 " [...] pode-se concluir que a Lei 6.404/1976 tem a visão dos grupos societários de fato como a relação entre sociedade controladora e sociedades controladas. Uma vez que a Lei 6.404/1976 trata das relações societárias a partir do conceito de sociedade controladora e controlada, pode-se afirmar ainda que o critério utilizado pelo legislador para verificar a existência de um grupo societário de fato é o poder de controle, sem exigir qualquer outro elemento ulterior que demonstre a unidade econômica do grupo, ressalvados os grupos de direito." (PRADO, 2006, p. 141).

16 Ibid., p. 146.

17 “Os mecanismos de proteção, baseados na ação de indenização, são de difícil implementação, quando não de impossível aplicação, diante das dificuldades de provar a ocorrência de tais medidas, tanto mais quando o exercício do poder de controle não raro prescinde de externalizações do tipo medidas, instruções, etc. Parece difícil ou impossível detectar tais medidas ou instruções lesivas só a partir da publicação de demonstrações financeiras e balanço consolidado (este último, se for o caso)." (BARROS, 1992, p. 167). Sobre a dificuldade de se compensar os prejuízos causados à controlada no direito alemão (modelo que inspirou a legislação brasileira), vide WIEDEMANN, 1982, p. 34-35. 
$\mathrm{Na}$ regulamentação legal dos grupos de sociedades, os credores são protegidos de maneira indireta apenas, por meio das regras de preservação do capital social da controlada. Este mecanismo de proteção é indireto pois o mecanismo para exercê-lo diretamente reside, em última instância, na mão dos acionistas minoritários, estes sim legitimados a propor ação de responsabilização contra a controladora, por abuso de poder de controle, ou contra os seus administradores, por agirem contra os interesses da companhia. $^{18}$

Ora, se a lei não prevê adequadamente a forma de funcionamento dos grupos de fato na realidade prática, evidente que os mecanismos de proteção aos credores previstos na LSA tendem a ser ineficientes na garantia desta proteção. Em razão disso, a desconsideração da personalidade jurídica acaba sendo utilizada pela jurisprudência como forma de proteger os interesses dos credores das sociedades controladas, os quais são completamente ignorados pela regulamentação dos grupos. A desconsideração da personalidade jurídica acaba se convertendo em um mecanismo de correção de uma distorção entre a realidade fática e a letra da lei.

\subsubsection{O problema da proteção dos minoritários}

Não diferente é a situação dos sócios minoritários das sociedades controladas nos grupos de fato. Não obstante o fato de nenhum dos julgados analisados abordar a questão da proteção dos acionistas minoritários, a LSA tampouco prevê mecanismos de proteção adequados aos interesses destes quando se trata de grupos de sociedades. Para CorrêaLima, "a posição do acionista minoritário das sociedades dependentes integradas num grupo mostra-se particularmente vulnerável a situações de abuso de direito, desvio de poder e conflito de interesses". ${ }^{19}$ Barros complementa:

Para os detentores do poder de controle esta é uma situação [a da ausência de razoável eficácia da regulação dos grupos] bastante conveniente, ao mesmo tempo em que os acionistas minoritários, os credores e a coletividade estão na

BARROS, 1992, p. 166-167.

19 CORRÊA-LIMA, Osmar Brina. Sociedade Anônima. 3. ed. Belo Horizonte: Del Rey, 2005, p. 393. 
prática desprotegidos diante do exercício do poder de controle lesivo a seus interesses. $^{20}$

Como ensina Munhoz, a proteção destes minoritários baseia-se na figura do abuso do poder de controle.

\begin{abstract}
Confere-se aos minoritários ação de reparação de danos contra a sociedade controladora em relação aos atos praticados com infração ao disposto nos arts. 116 e 177 (art. 246). Têm legitimidade para a ação os acionistas que representam $5 \%$ ou mais do capital social $\left(\S 1^{\circ}\right.$, alínea a), ou qualquer acionista, desde que preste caução pelas custas e honorários de advogado devidos, no caso de vir a ação ser julgada improcedente ( $\$ 1^{\circ}$, alínea b), Caso julgada procedente a ação, a sociedade deve pagar honorários de advogado de $20 \%$ e prêmio de $5 \%$ ao acionista que a propôs, calculados sobre o valor da indenização $\left(\S 2^{\circ}\right)$. Além da reparação por perdas e danos, entende-se aplicável à espécie o disposto no art. $115, \S 4^{\circ}$, que prevê a anulabilidade das deliberações tomadas em conflito de interesses com a companhia, ficando o acionista obrigado a reparar os danos e a transferir à sociedade as vantagens que tiver obtido. ${ }^{21}$
\end{abstract}

A ineficácia deste sistema, para o caso dos grupos de fato, já foi demonstrada, mas vale a pena reiterá-la.

Em primeiro lugar, destaca-se a dificuldade da comprovação do abuso de poder de controle ensejador de prejuízos às sociedades controladas. Os sistemas de transferência de ativos entre as sociedades integrantes do grupo podem ser de tal forma complexos que um minoritário não atuante na condução dos negócios sociais pode ter imensa dificuldade de identificar de forma precisa como se dá a subordinação do interesse da controlada ao interesse da controladora e/ou do grupo. Associe-se a esta dificuldade a inexistência de qualquer mecanismo de monitoração ou fiscalização, por parte dos minoritários, dos atos praticados entre as sociedades integrantes do grupo.

Além disso, outra dificuldade é a concentração de todos os custos da ação judicial a ser proposta para averiguação da existência de abuso de poder de controle no acionista que propuser a ação. Dependendo da situação, o acionista pode não ter nenhum incentivo na propositura da ação, comparando-se os custos que serão por ele arcados em contrapartida a

BARROS, 1992, p. 168.

MUNHOZ, 2002, p. 279. No mesmo sentido, ADAMEK, 2009, p. 407-410. 
uma mera expectativa de receber a adequada compensação ao final da ação judicial, mesmo levando em conta o prêmio descrito acima. ${ }^{22}$

Não possuem melhor sorte os acionistas minoritários no que diz respeito à possibilidade de responsabilização dos administradores que favorecerem sociedade controlada, coligada ou controladora, deixando de realizar operações com tais sociedades em condições comutativas ou mediante compensação adequada, como indica o art. 245 da LSA.

Imagine-se o caso em que uma sociedade integrante de um grupo societário sofreu determinado prejuízo em razão de operação realizada, em condições não comutativas com sua controladora, e que tal operação tenha sido aprovada por seus administradores sem que a adequada compensação fosse feita à sociedade controlada.

Neste caso, os acionistas minoritários, com base no art. 159 da LSA, poderiam propor ação para aferir a responsabilidade do administrador pelos prejuízos causados. Ocorre que a ação de responsabilidade civil contra o administrador prescinde de deliberação assemblear para ser proposta. E quem detém a maioria de votos na assembléia que deliberará esta matéria num grupo de fato por subordinação? Justamente a controladora que se beneficiou da operação não comutativa. As chances de que a propositura da ação não seja aprovada em assembléia são enormes.

É verdade que os acionistas podem propor a ação independente de deliberação da assembléia nos casos previstos nos $\S \S 3^{\circ}$ e $4^{\circ}$ do art. 159. Contudo, aplicam-se igualmente os argumentos descritos acima a respeito dos custos da ação, que podem ser demasiado elevados para que um acionista tenha o incentivo de propô-la. ${ }^{23}$

Vale destacar outra obervação de Adamek, relevante num contexto de grupos societários:

Afaste-se de cogitação, no entanto, a possibilidade de o acionista de uma
sociedade propor ação social isoladamente contra o administrador de outra
sociedade do grupo: o administrador de outra sociedade só poderá ser convocado
a eventualmente responder como partícipe, mas, nesse caso, a pretensão deverá

Conforme MUNHOZ, 2002, p. 280.

23 Conforme ADAMEK, 2009, p. 406-407. 
ser simultaneamente dirigida também contra o administrador da sociedade da qual o substituto processual é membro; fora disso, ao acionista apenas assistirá o direito de eventualmente propor ação social contra o controlador do grupo, nos termos do art. 246 da Lei das S/A [...]. ${ }^{24}$

Em suma, para o caso dos minoritários, o sistema de proteção é baseado na figura do abuso do poder de controle, estruturado segundo a premissa de que as sociedades grupadas preservam a sua independência e interesse particular. Não é isso o que ocorre na prática, e é justamente por isso que o sistema é falho. As sociedades integradas em um grupo de fato atuam como uma unidade econômica e, embora teoricamente vedado pela LSA, a subordinação dos interesses das sociedades controladas acaba sendo a regra. "Nos grupos de sociedades, porém, já ficou evidenciado que a interferência na autonomia da pessoa jurídica, seja no aspecto patrimonial, seja no organizativo é de natureza estrutural $[\ldots] " .25$

\subsubsection{A distinção entre a relação de grupo e a relação de mero controle}

O descasamento entre realidade fática e preceitos legais indicados anteriormente parece residir na distinção entre relação de mero controle e a relação de grupo.

Como visto, o regramento dos grupos de fato previsto na LSA está ligado à noção de controle. Mas o mero exercício do poder de controle de uma sociedade sobre outra é suficiente para caracterizar a configuração de um grupo de sociedades?

Numa relação de controle de uma sociedade sobre outra, parece claro que a sociedade controladora tem a possibilidade de influir, direta ou indiretamente, de modo decisivo, no processo de formação e execução da vontade social da sociedade da qual detém o controle. Sendo assim, a existência de controle leva a uma situação de dependência societária da sociedade controlada em face da sociedade controladora, na qual

\footnotetext{
ADAMEK, 2009, p. 407.

MUNHOZ, 2002, p. 173-174.
} 
a controladora tem a possibilidade de exercer influência dominante sobre a controlada. ${ }^{26}$

Mas esta situação, por si só, não caracteriza a existência de um grupo de sociedades, de acordo com as características desta figura empresarial que foram discutidas anteriormente. Segundo Embid Irujo, para que se caracterize o grupo de sociedades, a esta situação de dependência societária deve-se adicionar:

[...] el ejercicio de uma dirección económica común, que suponga la adaptación del comportamiento empresarial de la sociedad dependiente a las directrizes fijadas por la sociedad dominante [...]. La situación de dependencia, se nos presenta, así, como una forma intermedia o, más exactamente, como una forma de transición - y, por ello mismo, relativamente inestable - entre la sociedad economicamente independiente, cuya actividad se orienta exclusivamente por el criterio de la satisfacción de su própio interés, objeto de las normas de Derecho común de sociedades, y la sociedad de grupo, cuya actividad queda sometida a la de una unidad económica en la que se integra, y se vincula a la satisfacción de denominado interés del grupo. ${ }^{27}$

Prado fez o mesmo questionamento:

Questiona-se, entretanto, se a mera existência do controle societário é suficiente para configurar um grupo de sociedades. A configuração do grupo empresarial está associada à relação entre controle societário e direção unitária, sendo esta entendida como o elemento que diferencia o agrupamento da situação de mera dependência. ${ }^{28}$

Embora a dependência societária seja um elemento fundamental para o estabelecimento da unidade econômica - e, conseqüentemente, para a existência dos grupos de sociedades - estes conceitos não se confundem e não são necessariamente coincidentes, pois "nem sempre uma relação de controle corresponde a uma situação de grupo". 29

Para Embid Irujo, este problema com os conceitos de grupo e de controle deve-se à confusão que normalmente é feita com o caráter estritamente societário, que possui a

26 EMBID IRUJO, 1984a, p. 73.

27 Ibid., p.73-74.

28 PRADO, 2006, p. 105.

29 Ibid., p. 106. 
situação de controle de uma sociedade sobre outra, com o caráter estritamente empresarial, que existe no conceito de direção unitária. Trata-se, na relação de grupo, não de uma situação de mero controle, mas de uma profunda integração (e não mera justaposição) das sociedades dominante e dependente. É uma nova forma de empresa com interesse próprio, e não uma situação onde a sociedade dominante se limita a perseguir os interesses derivados de sua participação no capital social da sociedade dependente. ${ }^{30}$

A opinião é compartilhada por Prado:

\begin{abstract}
Para a caracterização dos grupos, portanto, mais do que as diversas formas de configuração do controle, importa conhecer os interesses do controlador no exercício do seu poder, isto é, se se trata de um sócio privado ou um sócio empreendedor com outros interesses empresariais que não simplesmente o de sócio na sociedade dependente. De fato, nos grupos de sociedades, o poder de controle é exercido em vista de interesses econômicos diversos da simples obtenção de lucros auferidos com o desenvolvimento da atividade empresarial distribuídos a todos os acionistas, $\mathrm{O}$ controlador não pretende apenas exercer os direitos decorrentes de sua posição de sócio, mas também coordenar a atividade da sociedade isolada, de acordo com uma esfera maior que representa o conjunto de todas as sociedades sob o seu domínio. ${ }^{31}$
\end{abstract}

Parece, portanto, que toda a discussão acerca do descasamento entre a realidade fática dos grupos de fato e o regramento desta figura empresarial prevista na LSA deve-se, em parte, à ausência de previsão da unidade empresarial existente nos grupos como elemento de caracterização destes para o direito brasileiro. A LSA regulamenta as relações entre as sociedades integrantes de grupos de fato apenas sob uma perspectiva do poder de controle, esquecendo-se de considerar que "[o] elemento que diferencia a relação de simples dependência e a de grupo refere-se a uma especial forma de exercício do poder de controle, que tem por parâmetro não o interesse da sociedade isolada, mas a política grupal."32. E a forma de implementar, nas sociedades controladas, a política grupal, estabelecendo uma unidade econômica, é por meio da direção unitária. ${ }^{33}$

Tanto que, em todos os julgados analisados anteriormente, especialmente aqueles do STJ, a direção unitária é sempre mencionada como elemento caracterizador da

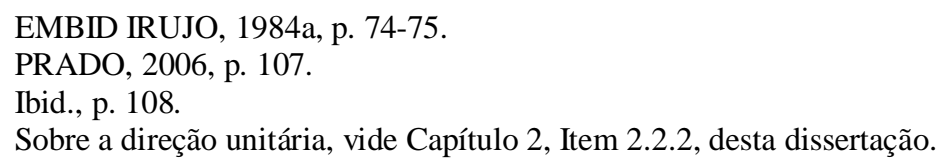


existência de grupo econômico, embora não exista qualquer previsão legal de direção unitária para sua caracterização na LSA. Trata-se de um caso no qual a jurisprudência adapta a legislação existente ao caso concreto, pois aquela não reflete adequadamente a realidade econômica dos grupos de sociedades.

Como a lei não define, de maneira condizente com a realidade, a figura dos grupos, os mecanismos legais de proteção a credores e acionistas minoritários torna-se ineficaz. Em face desta situação, a desconsideração da personalidade jurídica tornou-se arma poderosa no ajuste da realidade fática dos grupos de sociedades vis-à-vis a inadequação das regras previstas na LSA.

\title{
4.3 Desconsideração como mecanismo de ajuste da realidade
}

Teixeira e Guerreiro sustentam que o conceito de pessoa jurídica atualmente se submete a um processo de revisão (e esta afirmação permanece atualíssima, embora a obra destes autores seja datada de 1979). Isso porque a pessoa jurídica, como técnica de organização da empresa e separação patrimonial, passou, em alguns casos, a ser utilizada de maneira irregular, com o intuito de fraudar a lei, obrigações pactuadas e direitos de credores.

\begin{abstract}
A reação contra o uso abusivo da personalidade jurídica, em detrimento do interesse público, resultou na separação entre a aparência e a realidade da pessoa coletiva, como ponto de partida para a elaboração de uma série de construções jurisprudenciais e doutrinárias em cujo âmago se encontra a desconsideração da pessoa jurídica, sempre que esta se identifique como meio utilizado para a consecução de objetivos fraudulentos. ${ }^{34}$
\end{abstract}

34 TEIXEIRA; GUERREIRO, 1979, p. 705. No mesmo sentido: “[...] l'abuso della personalità giuridica si manifesta, in questo ordine di casi, in tre possibili forme: con la sistematica confusione fra il patrimonio della società e quello personale dei soci, i quali trattano i beni sociali come beni propri o impiegano danaro proprio per pagare i creditori della società; con la sistematica precostituzione delle decisioni dell'organo amministrativo della società. In questi casi si dovrá prendere atto che la personalità giuridica della società è stata ridotta a mero simulacro formale, al riparo del quale $i$ soci hanno agito alla stessa stregua dei soci di una società di persone; e dovrà essere pronunciata la loro decadenza dal beneficio della responsabilità limitada o, in caso di fallimento della società, dovrá essere pronunciato il loro personale fallimento." (GALGANO, 2003, p. 235). 
Para Leães, a autonomia patrimonial e a limitação da responsabilidade obtidas mediante $\mathrm{o}$ processo de personalização podem ser desconsideradas em certas circunstâncias.

\begin{abstract}
Concebidas, porém, para atender validamente as necessidades sociais, as pessoas jurídicas não podem ser questionadas, senão quando se abusa da personalidade jurídica com vista à realização de fraude. É dentro deste contexto que deve ser encarada a teoria da desconsideração (também chamada por teoria do 'superamento' ou da 'penetração') da pessoa jurídica, elaborada não para questionar o expediente técnico da pessoa jurídica, mas para aperfeiçoá-lo, preservando-o contra o uso indevido da personalização. ${ }^{35}$
\end{abstract}

A aplicação da desconsideração da personalidade jurídica por parte dos tribunais brasileiros pode ensejar uma extensão da responsabilidade patrimonial pelos débitos da sociedade controlada à sociedade controladora, desde que presentes os pressupostos autorizadores da aplicação da teoria. Tem-se, aqui, uma exceção potencial (embora excepcional) ao princípio da responsabilidade limitada dos sócios:

Tudo leva a crer, entretanto, no contexto do direito moderno, que esta doutrina encontre fecundo campo de aplicação entre nós, como resultado da tendência jurídica universal de conferir crescente importância à realidade econômica e sociológica na efetiva distribuição de justiça. A insuficiência patrimonial da controlada para atender à satisfação de suas dívidas, principalmente as de caráter tributário e trabalhista, nem sempre há de prevalecer, segundo pensamos, sobre os interesses maiores da coletividade, quando a personalidade jurídica distinta da controlada nada mais representa, senão escudo formal, protetivo do patrimônio separado da controladora, mais forte e rica, nas hipóteses em que a distinção entre uma e outra representa pura e simplesmente um artifício concebido apenas com o fim de prejudicar terceiros de boa fé. ${ }^{36}$

Não há dúvidas de que, se a controladora utiliza o benefício da separação patrimonial de suas controladas com o intuito de prejudicar terceiros de boa fé, a personalidade jurídica deve ser desconsiderada para coibir o desvio do instituto. No entanto, constantemente a desconsideração da personalidade jurídica das sociedades integrantes de grupos societários é utilizada para a responsabilização da controladora, mas

35 LEÃES, 2004, p. 376.

36 TEIXEIRA; GUERREIRO, 1979, p. 707. 
nem sempre como resultado de mau uso da personalidade jurídica. ${ }^{37}$

\author{
No mesmo sentido, Rossetti:
}

É certo e inquestionável que o funcionamento de determinada sociedade anônima não pode, em hipótese alguma, servir como meio para a prática de fraude ou ato abusivo, ou, ainda, como veículo para desvirtuar ou mesmo evitar a aplicação das normas jurídicas. Porém, devemos ter muita cautela quando da aplicação da teoria da desconsideração da personalidade jurídica, que vem ocorrendo de forma indiscriminada, independentemente do tipo de sociedade. ${ }^{38}$

As regras jurídicas existentes em nosso ordenamento, no que diz respeito aos grupos de fato, não regulam adequadamente o fenômeno. Como visto, o regramento jurídico das sociedades anônimas ainda é bastante centrado na sociedade isolada, e tais regras não se adaptam de forma plenamente satisfatória à realidade dos grupos de sociedades. ${ }^{39}$ Apesar da vedação existente ao prejuízo dos interesses de uma sociedade controlada aos interesses da controladora e/ou do grupo, na prática verifica-se que a controladora acaba por exercer uma direção unitária sobre as controladas, afetando direta ou indiretamente o interesse e o patrimônio destas sociedades. ${ }^{40}$

37 Conforme demonstrado nos itens 4.1.1 e 4.1.2 deste Capítulo.

38 ROSSETTI, Maristela Sabbag Abla. Análise da Aplicação da Teoria da Desconsideração da Personalidade Jurídica à Sociedade Anônima. In: CASTRO, Rodrigo R. Monteiro de; ARAGÃO, Leandro Santos de. (Coords.). Sociedade Anônima - 30 Anos da Lei 6.404/76, São Paulo: Quartier Latin, 2007, p. 391.

39 "De suerte que la regulación vigente em la mayoría de los países de nuestro entorno - con las excepciones de Alemania y Portugal - no se adecúa al modelo de sociedad que participa en el tráfico económico; la sociedad-isla es, en la actualidad, una figura en peligro de extinción y, en consecuencia, la regulación que la contempla debería ser objeto de revisión. Fundamentalmente porque, en el grupo, las sociedades que lo integran determinan su voluntad social de acuerdo a un mandato externo bien sea impuesto (en los grupos por subordinación), o bien concordado (en los grupos por coordinación), circunstancia que puede poner en peligro el interés social propio de cada sociedad agrupada. De tal manera que la persistencia en no reglar el fenónemo de los grupos de sociedades no hace sino entrar en crisis al modelo sobre el que descansa aún todo el edificio normativo de Derecho de sociedades." (ARRIBA FERNÁNDEZ, 2004, p. 33). Em nota de rodapé, Arriba Fernández menciona que fora da Europa, o Brasil, assim como Alemanha e Portugal, também entra na exceção de países que possuem regramento específico para os grupos de sociedades e, portanto, estaria "adequado a sociedades que participam do tráfico mercantil". Pelos motivos apresentados anteriormente nesta dissertação, e também pela jurisprudência analisada, pode-se perceber que não obstante a existência de regulamento específico no Brasil para os grupos de sociedades, o modelo ainda merece diversas críticas.

40 Conforme Galgano: “[...] l'influenza dominante che la controllante esercita sulla gestione delle controllate e che vale a ricondurre il gruppo ad unitá. Il problema di legislazione che ovunque i gruppi pongono è di evitare che tutto ciò si traduca in un pregiudizio per i creditori delle singole società, per il loro azionisti di minoranza e, più in generale, per il pubblico degli investitori." (GALGANO, 2003, p. 21). 
Com isso, minoritários e credores, principalmente, acabam por ser prejudicados, pois a legislação não prevê de forma adequada os mecanismos de sua proteção. Sendo assim, a desconsideração da personalidade jurídica das empresas pertencentes a grupos de sociedades acabou sendo utilizada pelos tribunais brasileiros para ajustar a realidade empresarial à realidade jurídica e, por isso, podemos dizer que, nestes casos, a desconsideração seria uma espécie de "mecanismo de ajuste da realidade". ${ }^{41}$

Na lição de Leães:

Cumpre, portanto, distinguir dos verdadeiros casos de desconsideração todos aqueles que tratam de mera imputação do ato, onde simplesmente se busca o verdadeiro agente, que se utiliza da pessoa jurídica como instrumento para o seu próprio comportamento. É nesse contexto que se insere a problemática dos grupos de sociedade, que exige tratamento diferenciado. Pois a este fenômeno é inerente um certo grau de confusão patrimonial, carecendo de uma nítida separação entre interesse grupal e interesse das sociedades. No grupo, a formação da vontade de uma sociedade é submetida ao permanente e incontrastável poder de controle de outra pessoa jurídica. Daí por que cabe, no grupo, prever normas de proteção de terceiros (credores e acionistas minoritários), através da admissão da responsabilidade direta da sociedade dominante, recorrendo-se às regras de imputação, sem que isso signifique remissão à técnica da desconsideração. ${ }^{42}$

O problema não está no mau uso dos grupos de sociedades (salvo exceções do caso concreto, obviamente), mas sim no regramento inadequado do fenômeno existente na LSA. Nesse sentido, vale reproduzir a opinião de Munhoz:

41 E a observação deste fato na doutrina não é recente: “[...] a admissão clara de submissão da pessoa jurídica a um centro de poder situado fora de seu âmbito formal - e cujos interesses passa a subordinar-se a pessoa jurídica 'controlada', 'subsidiária' ou integrante de um 'grupo' - faz surgir um quadro de realidades jurídico-sociais que não correspondem à situação 'normal', 'típica', de uma pessoa jurídica. [...] Reconhecendo a licitude de tal situação, os ordenamentos jurídicos procuram resguardar, ao menos, a integridade patrimonial da sociedade integrada no grupo (fático ou de Direito), em benefício de seus acionistas minoritários e de seus credores. [...] E é evidente que, quanto menos eficazes forem tais normas, maiores serão os clamores de aplicação de soluções na linha da 'desconsideração', dada a preocupação de não deixar ao desamparo os credores das sociedades controladas, subsidiárias, ou integrantes do grupo. [...] $\mathrm{Na}$ verdade, porém, a emergência dessa realidade jurídica que é o grupo de sociedades pode eventualmente servir de elemento detonador de aspecto novo da própria crise de sistema [...]. Esta crise do sistema eclodiria, no caso, sob o seguinte aspecto: deve o grupo de sociedades ser considerado uma sociedade de $2^{\circ}$ grau? $\mathrm{E}$, inversamente, pode a sucursal, estabelecimento com certo grau de autonomia técnica e econômica mas não dotado de personalidade jurídica, vir a ser considerada como uma nova espécie de pessoa jurídica? [...] E é exatamente por suscitar até mesmo uma revisão de noções aparentemente estabilizadas em definitivo - como a de sujeito de direito - que, em matéria de grupos de sociedades, a crise, que se limita aparentemente à função do instituto, acaba por ser também uma crise do próprio sistema jurídico" (OLIVEIRA, 1979, p. 591 e 595).

42 LEÃES, 2004, p. 378. 
Note-se que a disregard doctrine, desde sua origem até os dias atuais, é considerada o remédio para uma situação patológica (a crise da pessoa jurídica), representando uma tentativa de restabelecer os objetivos e os princípios traçados pelo ordenamento jurídico em relação a este instituto fundamental da dogmática jurídica [...]. [S]e a doença não se localiza em cada caso concreto, mas no próprio ordenamento jurídico, o que se exige não é a aplicação de uma teoria de origem jurisprudencial, mas sim a criação de uma nova disciplina jurídica, que seja apta a estabelecer princípios e objetivos consentâneos com as exigências da sociedade. [...] [E]m relação aos grupos de sociedade, o problema está [...] no modelo jurídico que entrou em crise, e não na fraude, no abuso de direito ou no desvio de finalidade, verificados em situações específicas, em relação às quais se justificasse a aplicação de um remédio [...]. [O]s grupos de sociedades não precisam da teoria clássica da desconsideração da personalidade, aplicada de maneira casuística, com o objetivo de restabelecer justamente os princípios e objetivos do ordenamento que se mostram incompatíveis com a estrutura sócio econômica das formas atuais de organização da atividade empresarial. $\mathrm{Na}$ verdade, os grupos de sociedades precisam é de um direito próprio, aderente à realidade empresarial, de tal forma que a doutrina da desconsideração, em vez de encontrar nesse fenômeno um dos seus maiores focos de aplicação, volte ao leito da excepcionalidade, atuando como remédio apto a enfrentar abusos de direito, fraudes e desvios de finalidade, identificados em casos específicos. ${ }^{43}$

Não obstante a existência de opinião diversa na doutrina ${ }^{44}$, acredita-se que a principal razão da grande aplicação da desconsideração da personalidade jurídica aos grupos de sociedades é justamente o divórcio existente entre o direito e a realidade no que diz respeito a esta figura empresarial.

Bulhões Pedreira comentando parecer, em que a Comissão de Valores Mobiliários (CVM) defendeu a aplicação da desconsideração da personalidade jurídica das sociedades integrantes de um grupo como forma de assegurar a aplicação do art. 254 da LSA, afirmou que a medida era descabida.

Embora os comentários de Bulhões Pedreira, para este caso, fossem específicos para o afastamento da incidência do art. 254 ao caso em questão, vale a pena transcrever aqui um trecho, visto evidenciar a constante aplicação equivocada do instituto da desconsideração da personalidade jurídica aos grupos societários:

[...] A Lei $n^{\circ}$ 6.404/76 admite expressamente e regula os grupos de sociedades de fato e cria quadro institucional próprio para a organização de grupos de

43 MUNHOZ, 2002, p. 174-178.

44 “Aplicar a Disregard Doctrine aos grupos de empresas significa evitar o tão condenável divórcio entre o Direito e a realidade, reconhecendo-se as relações de controle e os interesses comuns, existentes entre as empresas componentes de grupos, e solucionando-se os problemas daí decorrentes, à luz do ordenamento jurídico.” (KOURY, 1998, p. 200). 
sociedades de direito, e entende que estes grupos, como instituição fundamental na organização das grandes empresas que caracterizam a moderna economia de mercado, não devem ter a sua formação e funcionamento dificultados, mas que a lei deve limitar-se a regular o comportamento das sociedades, seus administradores e acionistas nas situações e relações peculiares do grupo. [...] $\mathrm{Na}$ disciplina dos grupos de sociedade, a lei de sociedades por ações manteve a orientação tradicional do direito brasileiro de reconhecer todos os efeitos da personificação jurídica e, para evitar dúvidas, reafirmou expressamente a distinção da personalidade jurídica e patrimônio de cada sociedade [...]. Por conseguinte, no sistema da lei a formação e o funcionamento do grupo de sociedades - de fato ou de direito - são negócios ou atividades lícitos, que resultam do exercício regular de direitos. [...]. A invocação da teoria da desconsideração da pessoa jurídica para resguardar a plena vigência do artigo 254 da lei de sociedades por ações importa completa inversão da ordem lógica das normas gerais, especiais e excepcionais que são elementos do sistema da lei. $^{45}$

Ora, os grupos econômicos foram criados justamente para racionalizar a exploração empresarial, harmonizando e até mesmo unificando as atividades das várias empresas que o compõem. Cabe ao Direito, então, disciplinar o instituto em função dos vários interesses em jogo (controladoras, controladas, minoritários e credores). Para muitos doutrinadores, a solução para este dilema seria a criação de um direito específico para os grupos de sociedades. ${ }^{46,47}$

Lobo faz determinadas indagações sobre o regramento jurídico dos grupos societários no direito brasileiro que bem mostram o descompasso existente entre nosso direito e a realidade.

Se, como disse Marx, o Direito é um servidor da Economia, por que o Direito positivo e, portanto, o Direito dos Grupos de Sociedades deve ter por objeto apenas as relações entre sociedades que aderem e subscrevem uma convenção, segundo o sistema contratual, quando o fenômeno econômico de concentração de

45 LAMY FILHO, Alfredo; PEDREIRA, José Luiz Bulhões. A Lei das S.A. - pareceres. 2. ed. Rio de Janeiro: Renovar, 1996. v. II, p. 633-634.

46 "O dilema do direito tradicional é, pois, muito claro: ou se aplicam, rigidamente, as normas editadas para o funcionamento de uma sociedade isolada, tornando ilegal e abusiva esta confusão patrimonial, e condenando, portanto, o grupo econômico a uma vida à margem da ordem jurídica; ou, ao contrário, suspende-se, completamente, a aplicação dessas normas e, em conseqüência, os interesses, tanto dos não controladores quanto dos terceiros credores, ficam ao desamparo. A fuga deste dilema consiste na criação do direito dos grupos econômicos, como sistema complementar ao direito societário tradicional" (COMPARATO; SALOMÃO FILHO, 2008, p. 500).

47 No mesmo sentido, Munhoz: "Na verdade, os grupos de sociedades precisam é de um direito próprio, aderente à realidade empresarial, de tal forma que a doutrina da desconsideração, em vez de encontrar neste fenômeno um dos seus maiores focos de aplicação, volte ao leito da excepcionalidade, atuando como remédio apto a enfrentar abusos de direito, fraudes e desvios de finalidade, identificados em casos específicos.” (MUNHOZ, Eduardo Secchi. Desconsideração da Personalidade Jurídica e Grupos de Sociedades. RDM, ano XLIII, v. 134, p. 25-47, abr./jun. 2004, p. 47). 
empresas não distingue grupos de sociedades de direito e grupos de sociedades de fato? [...] Por que o Direito dos Grupos de Sociedades deve ficar preso a fórmulas legais que não abarcam, em toda a sua extensa amplitude, a realidade dos grupos de sociedades? ? $^{48}$

Antunes afirma que:

[...] as empresas plurissocietárias são estranhas criaturas no mundo econômico contemporâneo, geradas no ventre geneticamente antinómico do direito societário moderno: as razões que tornaram possível o seu nascimento são as mesmas que explicam os fracassos e becos sem saída da sua disciplina actual. Por isso, é nossa convicção profunda que qualquer futura regulação jurídica deste fenómeno apenas poderá ter êxito caso, numa espécie de "regresso às origens", sejam reequacionadas, de modo consistente e global, as próprias fundações do Direito das Sociedades do séc. XXI, desfazendo definitivamente o nó górdio entretecido pela sua paradoxal genealogia: Enquanto isto não for feito, não é de esperar qualquer avanço ou progresso significativo na matéria. ${ }^{49}$

A criação de um direito específico para os grupos de sociedades deveria, portanto, estabelecer formas específicas de responsabilização de controladores e proteção a minoritários e credores distintas da desconsideração da personalidade jurídica. Enquanto um sistema de regulamentação dos grupos societários condizente com a função econômica desta figura empresarial não for desenvolvido, a desconsideração da personalidade jurídica continuará a ser utilizada por nossos tribunais para ajustar a realidade. Por meio da desconsideração, os magistrados farão justiça, protegendo os interesses daqueles que, atualmente, possuem interesses totalmente desprotegidos.

Assim, permanecerá a insegurança jurídica atualmente existente com relação à aplicação da desconsideração aos grupos societários, utilizada em casos onde normalmente se extrapolam os princípios que ensejam a sua aplicação. Não há dúvida que isso, causa prejuízos para a atividade econômica como um todo. ${ }^{50}$ Nas palavras de Petitpierre-Sauvain, "Les groupes posent, en fait des problèmes qui nécessitent une revision non seulement du droit des sociétés mais des concepts de base du droit commercial et des rapports de ce droit avec la réalité économique. "51

48 LOBO, 1997, p. 120-121.

49 ANTUNES, José A. Engracia. Estrutura e Responsabilidade na Empresa: o moderno paradoxo regulatório. Revista de Direito GV, v.1, n.2, p. 29-68, jun./dez. 2005, p. 52.

50 Também nesta mesma linha, PRADO, 2005, p. 17-19.

51 PETITPIERRE-SAUVAIN, Anne. Droit des Sociétés et Groupes de Sociétés. Genebra: Centre d'Études Juridiques Européenes, 1972, p. 142. 


\section{CONCLUSÃO}

As sociedades por ações, surgidas na Idade Média como mecanismo hábil a viabilizar a exploração do novo mundo na era dos descobrimentos, revelaram-se instrumentos valiosos no desenvolvimento do capitalismo. Com a Revolução Industrial e o desenvolvimento tecnológico, vultosas somas de capital passaram a ser requeridas para o exercício da atividade produtiva.

Nesse contexto, as sociedades por ações adquiriram relevância no cenário econômico mundial na medida em que suas principais características eram fundamentais para se atingir os objetivos dos empresários da época. A limitação da responsabilidade permitia a segregação de riscos e incentivava o investimento, já que o empresário não responderia com seu patrimônio pessoal em caso de infortúnio nos negócios. A livre circulação de ações trazia dinamismo ao investimento e à economia, visto que a pessoa do sócio não mais era essencial para o desenvolvimento da atividade mercantil. A autonomia patrimonial criava um novo centro de imputação de obrigações, completamente distinto de seus sócios.

Deu-se, então, um movimento de grande concentração empresarial. Em decorrência das razões econômicas, mencionadas no Capítulo 2, item 2.1.1 deste trabalho, a consolidação de empresas promovida ao longo do século XIX e início do século XX mostrou-se forma eficiente de exploração da atividade econômica.

Essa situação não se perpetuou para sempre, contudo - e é natural que não fosse assim. Mudanças no cenário e conjuntura econômica mostraram aos empresários que nem sempre a estrutura da grande empresa é a mais vantajosa. Por motivos diversos, dentre os quais as razões mencionadas no Capítulo 2, item 2.1.2 deste trabalho, a organização da atividade empresarial em sociedades distintas pode ser mais eficiente economicamente.

Eis a margem para o surgimento dos grupos de sociedades. Técnica de organização da atividade empresarial, os grupos de sociedades são formados por sociedades distintas, unidas por uma direção unitária. Por cada sociedade dele integrante preservar sua personalidade jurídica, cada sociedade agrupada permanece como sujeito de direito 
independente, com patrimônio próprio, mas formando uma unidade econômica decorrente da direção unitária exercida pela sociedade de comando do grupo.

Essa estrutura traz grandes vantagens à organização empresarial, tais como a limitação do risco do negócio, a redução de custos de transação, a flexibilidade da organização empresarial e a mobilidade do investimento, entre outros. Em vista disso, os grupos societários passaram a desempenhar papel de destaque nas estruturas empresariais modernas.

Os grupos societários organizam-se sob as mais diversas formas. Para fins desta dissertação, interessam os grupos de fato por subordinação. Neles, as sociedades vinculamse em estruturas hierárquicas de controle e coligação nas quais uma sociedade, dita controladora, exerce direção unitária sobre as demais sociedades, ditas controladas, conferindo unidade econômica à atuação de todas elas.

A direção unitária, exercida pela sociedade controladora sobre as sociedades controladas, decorre da influência dominante que a primeira tem sobre as últimas. Essa influência dominante, de difícil definição, caracteriza-se pela capacidade da controladora de influir nos rumos da atividade empresarial das sociedades controladas. Ao passo em que essa influência dominante é exercida em caráter permanente, instala-se a direção unitária e tem-se um grupo de sociedades.

No direito brasileiro - o qual é fortemente inspirado na sistemática alemã de regulação dos grupos de sociedades, em oposição ao modelo anglo-saxão de regulação dos grupos e a outras propostas de regulação desenvolvidas na Europa - não há menção à direção unitária para caracterização dos grupos de fato, embora a doutrina seja praticamente unânime que esta é a sua principal característica. Ao contrário, o sistema de regulação da LSA a respeito dos grupos de fato parte do princípio de que as sociedades integrantes do grupo mantêm sua independência jurídica, e que por isso seus interesses não podem se subordinar aos interesses do grupo.

Sabe-se que, na prática, não é isso que ocorre. No exercício da direção unitária, freqüentemente, a sociedade controladora impõe medidas, orientações ou outra forma de direcionamento das atividades da controlada que resultam em prejuízo para esta, em benefício do grupo. Embora o direito brasileiro contenha determinações de que a sociedade 
controlada não pode ser prejudicada na realização de operações não comutativas com outras empresas do grupo, exceto se mediante adequada compensação, esta compensação quase nunca ocorre e é difícil de ser calculada.

O resultado é uma regulamentação societária, aplicável aos grupos, completamente descasada com a realidade econômica e ineficiente no que diz respeito à proteção dos interesses dos demais envolvidos, como acionistas minoritários e credores.

Ciente desta problemática - da inadequação da legislação aplicável aos grupos de sociedades para regular o fenômeno e, por conseqüência, para proteger os interesses dos acionistas minoritários e credores -, a jurisprudência passou a empregar a desconsideração da personalidade jurídica como meio para corrigir esta distorção jurídico-fática.

A desconsideração da personalidade jurídica não parece ser o mecanismo mais adequado para corrigir eventuais distorções existentes na legislação aplicável aos grupos de sociedades. Ela deve ser aplicada em casos de abuso de direito, confusão patrimonial entre a sociedade e seus sócios ou fraude à lei ou aos estatutos, pois a desconsideração visa superar o benefício da separação patrimonial quando este é mal utilizado pelos sócios da sociedade.

Isso porque a existência de um grupo, por si só, não representa utilização abusiva da personalidade jurídica. Muito pelo contrário, os grupos de sociedades são expressamente reconhecidos pelo ordenamento brasileiro. Contudo, na ausência de regras adequadas de imputação de responsabilidade às empresas integrantes de grupos societários - tais como as indicadas no Capítulo 4, itens 4.2 e seguintes deste trabalho, isto é, a ausência de mecanismos de proteção direta aos credores, a dificuldade de calcular o pagamento compensatório adequado à sociedade prejudicada em detrimento do interesse do grupo e as dificuldades impostas aos acionistas minoritários para propor ações de responsabilidade contra o administrador e contra a sociedade controladora por abuso de poder de controle -, a jurisprudência aplica a desconsideração da personalidade jurídica como forma de proteger interesses das minorias não expressamente tutelados pela legislação.

A LSA foi promulgada num contexto histórico e político de incentivo à concentração empresarial. Sendo assim, a LSA gravita em torno da figura do acionista controlador, senhor dos rumos da sociedade. Os direitos reservados às minorias são 
pequenos, justamente para viabilizar a formação da "grande empresa nacional", tão almejada na Exposição de Motivos da LSA. Possivelmente, esta é a principal explicação para a ausência de regras específicas de proteção aos acionistas minoritários e credores de grupos de sociedades: seria um desincentivo à sua formação.

Desde 1976, quando a LSA foi promulgada, nenhuma alteração ao regime proposto para os grupos de sociedades foi feita. Restou à jurisprudência, portanto, tentar fazer justiça no caso concreto por outros meios.

Ainda que a intenção dos magistrados que se utilizam da desconsideração da personalidade jurídica de empresas integrantes de grupos societários para a proteção de credores e acionistas minoritários seja louvável, a medida não é a mais adequada.

Como dito alhures, a desconsideração da personalidade jurídica deve ser usada em situações excepcionais, para coibir o uso patológico da pessoa jurídica. Seu uso para solucionar questões decorrentes das falhas existentes na legislação aplicável aos grupos de sociedades traz insegurança jurídica e pode inclusive gerar uma responsabilização demasiado gravosa para a sociedade de controle do grupo. Em última instância, o uso sem limites da desconsideração da personalidade jurídica aos grupos de sociedade pode inviabilizar a utilização desta figura na prática empresarial.

É o que sustenta Barros:

\begin{abstract}
Enquanto o direito positivo persistir na técnica da personalidade jurídica distinta das sociedades isoladas como um princípio absoluto, mesmo diante da supressão da autonomia patrimonial das sociedades grupadas, o Poder Judiciário se vê na contingência de aplicar, como forma de justiça aos terceiros credores, a doutrina da desconsideração da personalidade jurídica. Com isso, perde o direito positivo em credibilidade, quando o Poder Judiciário vai buscar na doutrina, e não nas normas legais, os subsídios de que necessita para fazer justiça. ${ }^{52}$
\end{abstract}

Sendo assim, os grupos de sociedades carecem de uma regulamentação específica que regule adequadamente os interesses de todas as partes envolvidas (controladores, controladas, acionistas minoritários, credores, trabalhadores e etc.). A doutrina especializada busca um modelo ideal para esta regulação há anos, mas ainda não se chegou a uma resposta final.

52 BARROS, 1992, p. 172. 


\section{REFERÊNCIAS}

\section{Doutrina}

ADAMEK, Marcelo Vieira Von. Responsabilidade Civil dos Administradores de S/A e as Ações Correlatas. São Paulo: Saraiva, 2009.

ANDRADE FILHO, Edmar Oliveira. A Desconsideração da Personalidade Jurídica no Novo Código Civil. São Paulo: MP, 2005.

ANTUNES, José A. Engrácia. Liability of Corporate Groups. Deventer: Kluwer Law and Taxation, 1994.

. Os Grupos de Sociedades. 2. ed. Coimbra: Almedina, 2002.

. Estrutura e Responsabilidade na Empresa: o moderno paradoxo regulatório. Revista de Direito GV, v.1, n.2, p. 29-68, jun./dez. 2005.

ARRIBA FERNÁNDEZ, María Luisa de. Derecho de Grupos de Sociedades. Madrid: Civitas, 2004.

ASCARELLI, Tullio. Problemas das Sociedades Anônimas e Direito Comparado. Campinas: Bookseller, 2001.

BANDEIRA, Gustavo. Dano ambiental e Violação da Função Social da Pessoa Jurídica. Fundamento para a Responsabilização Patrimonial do Sócio: Relativização da Pessoa Jurídica. Revista da EMERJ, v. 7, n. 28, p. 167-203, 2004.

BARBI FILHO, Celso. Ilegalidade da Arrecadação dos Bens da Sociedade Controlada na Falência de sua Controladora. RDM, n. 116, p. 211-214, out./dez. 1999.

BARROS, Cecília Vidigal Monteiro de. A Responsabilidade da Sociedade Controladora pelas Dívidas da Sociedade Controlada nos Grupos de Sociedades no Direito Brasileiro e Alemão. 1992. Dissertação (Mestrado) - Faculdade de Direito, Universidade de São Paulo, São Paulo, 1992. 
BICKER, Eike Thomas. Creditor Protection in the Corporate Group. July 2006. Disponível em: <www.ssrn.com/abstract=920472>. Acesso em: 29 dez. 2010.

BLUMBERG, Phillip I. The Law of Corporate Groups - substantive law. London: Little, Brown and Company, 1987. et al. Blumberg on Corporate Groups. 2. ed. Frederick: Aspen, 2007. v. 1 a 5.

BREAKLEY, Richard A.; MYERS, Stewart C.; ALLEN, Franklin. Princípios de Finanças Corporativas. Trad. Maria do Carmo Figueira e Nuno de Carvalho. 8. ed. São Paulo: McGraw-Hill Interamericana do Brasil, 2008.

CAMARGO, André Antunes Soares de. A Pessoa Jurídica: Um Fenômeno Social Antigo, Recorrente, Multidisplinar e Global. In: FRANÇA, Erasmo Valladão de Azevedo e Novaes (Coord.). Direito Societário Contemporâneo I. São Paulo: Quatier Latin, 2009, p. 281-298.

CARLTON, Dennis W.; PERLOFF, Jeffrey M. Modern Industrial Organization. 4. ed. Nova York: Addison Wesley Longman, 2005.

CARVAlHOSA, Modesto. Comentários à Lei de Sociedades Anônima. 2. ed. São Paulo: Saraiva, 2003. v. 4. tomo II.

CASTELLÕES, Leonardo de Gouvêa. Grupos de Sociedades. Curitiba: Juruá, 2008.

CHARVÉRIAT, Anne et al. Mémento Practique Francis Lefebvre - Groupes de Sociétés. Levallois: Francis Lefebvre, 2006.

CLARK, Robert Charles. Corporate Law. 13. Imp. New York: Aspen Law \& Business, 1986.

COASE, Ronald H. The Relevance of Transaction Costs in the Economic Analysis of Law. In: PARISI, Francesco; ROWLEY, Charles (Org.). The Origins of Law and Economics Essays by the Founding Fathers. Cheltenham: The Locke Institute, 2005. p. 199-221.

COELHO, Fábio Ulhoa. Curso de Direito Comercial. São Paulo: Saraiva, 2002. v. 2.

COMPARATO, Fábio Konder. Aspectos Jurídicos da Macro-Empresa. São Paulo: RT, 1970. 
Os Grupos Societários na Nova Lei de Sociedades por Ações. RDM, n. 23, p. 91107, 1976.

- Grupo Societário Fundado em Controle Contratual e Abuso de Poder do Controlador. In: . Direito Empresarial - estudos e pareceres, São Paulo: Saraiva, 1995b.

__ Na proto-história das empresas multinacionais: o Banco Medici de Florença. In: . Direito Empresarial, São Paulo: Saraiva, 1995a.

; SALOMÃO FILHO, Calixto. O poder de controle na Sociedade Anônima. 5. ed. Rio de Janeiro: Forense, 2008.

CORRÊA-LIMA, Osmar Brina. Sociedade Anônima. 3. ed. Belo Horizonte: Del Rey, 2005.

COZIAN, Maurice; VIANDIER, Alain; DEBOISSY, Florence. Droit des Sociétés. 21. ed. Paris: LexisNexis, 2008.

CUNHA, Rodrigo Ferraz Pimenta da. Estrutura de Interesses nas Sociedades Anônimas hierarquia e conflitos. São Paulo: Quartier Latin, 2007.

DAMODARAN, Aswath. Investment valuation. 2. ed. New York: John Wiley \& Sons, 2002.

DOBSON, Juan M. El Abuso de la Personalidade Jurídica. Buenos Aires: Depalma, 1985.

EINSENBERG, Melvin Aron. The Structure of the Corporation - a legal analysis. Washington, DC: BeardBooks, 2006.

EMBID IRUJO, José Miguel. Grupos de Sociedades y Accionistas Minoritarios. Madrid: Ministerio de Justicia - Centro de Publicaciones, 1984a.

Algunas Reflexiones sobre los Grupos de Sociedades y su Regulación Juridica. $R D M$, ano XXIII, n. 53, p. 18-40, jan./mar. 1984b.

Introducción al Derecho de los Grupos de Sociedades. Granada: Comares, 2003. 
Trends and Realities in the Law of Corporate Groups. European Business Organization Law Review, n. 6, p. 65-91, 2005.

FARINA, Elizabeth Maria M. Q.; AZEVEDO, Paulo Furquim de; SAES, Maria Sylvia Macchione. Competitividade: Mercado, Estado e Organizações, São Paulo: Singular, 1997.

FORGIONI, Paula A. Os Fundamentos do Antitruste, São Paulo: RT, 1998.

A Interpretação dos Negócios Empresariais no Novo Código Civil. RDM, ano XLII, n. 130, p. 7-38, abr./jun. 2003.

. O Contrato de Distribuição. São Paulo: RT, 2005.

A Evolução do Direito Comercial Brasileiro: da mercancia ao mercado. São Paulo: RT, 2009.

FRANÇA, Erasmo Valladão de Azevedo e Novaes. Conflito de Interesses nas Assembléias de S.A. São Paulo: Malheiros, 1993.

FRANCO, Vera Helena de Mello. Particularidades da "Affectio Societatis" no Grupo Econômico. RDM, ano XXXII, n. 89, p. 47-55, jan./mar. 1993.

FUENTES NAHARRO, Mónica. Grupos de Sociedades y Protección Acreedores (Una Perspectiva Societária), Navarra: Thomson Civitas, 2007.

GAGLIANO, Pablo Stolze; PAMPLONA FILHO, Rodolfo. Novo Curso de Direito Civil. São Paulo: Saraiva, 2003. v. I.

GALGANO, Francesco. Lex Mercatoria, Bolonha: il Mulino, 2001. Le Società - I Gruppi di Società, Torino: UTET, 2003.

GOLDSCHMIDT, Levin. Storia Universale del Diritto Commerciale. Trad. Vittorio Pouchain e Antonio Scialoja. Turim: Unione - Torinese, 1913.

GRASSI, Robson Antonio. Williamson e 'Formas Híbridas': uma proposta de redefinição do debate. Economia e Sociedade, Campinas, v. 12, n. 1, p. 43-64, jan./jun. 2003. 
GUERREIRO, José Alexandre Tavares. Conflitos de Interesse entre Sociedade Controladora e Controlada e entre Coligadas, no Exercício do Voto em Assembléias Gerais e Reuniões sociais. RDM, ano XXII, n. 51, p. 29-32, jul./set. 1983.

. Sociedade Anônima: poder e dominação, RDM, n. 53, p. 72-80, jan/mar 1989.

GUIDUGLI, João Henrique. Controle Externo Contratual. São Paulo: Quartier Latin, 2006.

HOPT, Klaus J. Comparative Company Law. 1 dec. 2006. Disponível em: <http://www.ssrn.com/abstract=980981>. Acesso em: 30 maio 2008

HOUIN, Roger. Les Groupes de Sociétés em Droit Français. In: HOPT, Klaus J. (Org.). Groups of Companies in European Laws. Berlin: Walter de Gruyer, 1982. v. II.

JAEGER, Pier Giusto. L'Interesse Sociale Rivisitato (quarant'anni dopo). Giurisprudenza Commerciale, Milano, n. XXVII, parte I, fasc. 1, p. 795-812, 2000.

KOENIG, Thomas; GOGEL, Robert; SONQUIST, John. Models of the Significance of Interlocking Corporate Directorates. American Journal of Economics and Sociology, v. 38, n. 2, p. 173-186, Apr. 1979.

KOURY, Suzy Elizabeth Cavalcante. A Desconsideração da Personalidade Jurídica (Disregard Doctrine) e os Grupos de Empresas. 2. ed. Rio de Janeiro: Forense, 1998.

KRAAKMAN, Reinier R. et al. The Anatomy of Corporate Law. New York: Oxford University, 2006.

KRUGMAN, Paul; WELLS, Robin. Introdução à Economia. Trad. Helga Hoffmann. Rio de Janeiro: Elsevier, 2007.

LAMY FILHO, Alfredo; PEDREIRA, José Luiz Bulhões. A Lei das S.A. - pareceres. 2. ed. Rio de Janeiro: Renovar, 1996. v. II.

; ___ A Lei das S.A. - pressupostos, elaboração e aplicação. 3. ed. Rio de Janeiro: Renovar, 1997. v. I. 
; ___ (Coords.). Direito das Companhias. Rio de Janeiro: Forense, 2009. vol.

II.

LAZZARESCHI NETO, Alfredo Sérgio. Lei das Sociedades por Ações Anotada. 3. ed. São Paulo: Saraiva, 2010.

LEÃES, Luiz Gastão Paes de Barros. Desconsideração da Personalidade Jurídica. In: Pareceres. São Paulo: Singular, 2004. p. 371-384.

LOBO, Carlos Augusto da Silveira; NEY, Rafael de Moura Rangel. Conflito de Interesses entre o Administrador e a Companhia - inexistência de impedimento de votar em deliberação do Conselho de Administração da controlada, do qual é membro, que aprova concessão de mútuo à controladora, da qual é Chefe do Departamento Jurídico. $R D M, \mathrm{n}$. 144, p. 275-286, out./dez. 2006.

LOBO, Jorge. Direito dos Grupos de Sociedades. RDM, n. 107, p. 99-122, jul./set. 1997.

MUNHOZ, Eduardo Secchi. Empresa Contemporânea e Direito Societário. São Paulo: Juarez de Oliveira, 2002.

Desconsideração da Personalidade Jurídica e Grupos de Sociedades. RDM, ano XLIII, v. 134, p. 25-47, abr./jun. 2004.

MUNIZ, Joaquim P. Princípio da Autonomia Patrimonial e Desconsideração da Personalidade Jurídica. Revista de Direito Empresarial IBMEC, Rio de Janeiro, v. 1, p. $145-170,2003$.

NUNES, Márcio Tadeu Guimarães. Desconstruindo a Desconsideração da Personalidade Jurídica. São Paulo: Quartier Latin, 2007.

NUNES, Simone Lahorgue; BIANQUI, Pedro Henrique Torres. A Desconsideração da Personalidade Jurídica: Considerações sobre a Origem do Princípio, sua Positivação e a Aplicação no Brasil. In: FRANÇA, Erasmo Valladão de Azevedo e Novaes (Coord.). Direito Societário Contemporâneo I, São Paulo: Quatier Latin, 2009. p. 299-328.

OLIVEIRA JÚNIOR, Antônio Sydney de. O Contrato Como Poder de Influência Dominante e as Conseqüências do seu Uso Abusivo. São Paulo: Método, 2004. 
OLIVEIRA, J. Lamartine Corrêa de. A dupla Crise da Pessoa Jurídica. São Paulo: Saraiva, 1979.

PEDREIRA, José Luiz Bulhões. Acordo de Acionistas sobre Controle de Grupo de Sociedades. Revista de Direito Bancário, do Mercado de Capitais e da Arbitragem, n. 15, p. 226-248, jan./mar. 2002.

PEREIRA NETO, Edmur de Andrade Nunes. Anotações sobre os Grupos de Sociedades. $R D M$, ano XX, n. 82, p. 30-38, abr./jun. 1991.

PEREIRA, Caio Mário da Silva. Instituições de Direito Civil. 19. ed. Rio de Janeiro: Forense, 2000. v. I.

PETITPIERRE-SAUVAIN, Anne. Droit des Sociétés et Groupes de Sociétés. Genebra: Centre d’Études Juridiques Européenes, 1972.

PINHEIRO, Armando Castelar; SADDI, Jairo. Direito, Economia e Mercados. Rio de Janeiro: Elsevier, 2006.

PINTO, Luís Felipe de Carvalho. Grupo de Sociedades e Abuso do Acionista Controlador. $R D M$, n. 108, p. 171-185, out./dez. 1997.

PRADO, Viviane Muller. Noção de Grupo de Empresas para o Direito Societário e para o Direito Concorrencial. Revista de Direito Bancário e do Mercado de Capitais, n. 2, p. 140156, maio/ago. 1998.

Grupos Societários: análise do modelo da Lei 6.404/76. Revista Direito GV, v. 1, n. 2, p. 5-28, jun./dez. 2005.

. Conflito de Interesses nos Grupos Societários. São Paulo: Quartier Latin, 2006.

PRENTICE, D.D. Groups of Companies: The English Experience. In: HOPT, Klaus J. (Org.). Groups of companies in European Laws. Berlin: Walter de Gruyter, 1982. v. II.

RAMSAY, Ian M. Allocating liability in corporate groups: an Australian perspective. Disponível em: <www.ssrn.com/abstract=1024901〉. Acesso em: 30 maio 2008. 
REQUIÃO, Rubens. Abuso de Direito e Fraude Através da Personalidade Jurídica. $R T$, n. 410, p. 12-24, dez. 1969.

. Curso de Direito Comercial. 22. ed. São Paulo: Saraiva, 2000.

ROSSETTI, Maristela Sabbag Abla. Análise da Aplicação da Teoria da Desconsideração da Personalidade Jurídica à Sociedade Anônima. In: CASTRO, Rodrigo R. Monteiro de; ARAGÃO, Leandro Santos de. (Coords.). Sociedade Anônima - 30 Anos da Lei 6.404/76. São Paulo: Quartier Latin, 2007.

SAlOMÃO FILHO, Calixto. Direito Concorrencial - as estruturas. 2. ed. São Paulo: Malheiros, 2002.

. O Novo Direito Societário. 3. ed. São Paulo: Malheiros, 2006.

SCHMIDT, Dominique. Les Conflits d'Intérêts dans la Société Anonyme. Paris: Joly, 2004.

SEMON, Juan M. Nuevo Derecho Accionario y de “Konzern” de Alemania - Ley de 1965. Buenos Aires: Cangallo, 1969.

SILVA, José Afonso da. Curso de Direito Constitucional Positivo. 18. ed. São Paulo: Malheiros, 2000.

SZTAJN, Rachel. Terá a Personificação das Sociedades função econômica? In: PERIN JÚNIOR, Ecio et al. Direito Empresarial - aspectos atuais de direito empresarial brasileiro e comparado. São Paulo: Método, 2005.

TEIXEIRA, Egberto Lacerda; GUERREIRO, José Alexandre Tavares. Das Sociedades Anônimas no Direito Brasileiro. São Paulo: Bushatsky, 1979. v. II.

VIDIGAL, Geraldo de Camargo; MARTINS, Ives Gandra da Silva (Coords.). Comentários à Lei de Sociedades por Ações. Rio de Janeiro: Forense, 1999

WALD, Arnoldo. Caracterização do Grupo Econômico de Fato e suas Conseqüências Quanto à Remuneração dos Dirigentes de suas Diversas Sociedades Componentes. Revista de Direito Bancário e Mercado de Capitais, n. 25, p. 145-161, jul./set. 2004. 
; EIZIRIK, Nelson. A Designação "Grupo de Sociedades” e a Interpretação do art. 267 da Lei das S/A. RDM, n. 54, p. 51-66, 1984.

WARDE JÚNIOR, Walfrido Jorge. Responsabilidade dos Sócios. Belo Horizonte: Del Rey, 2007.

WIEDEMANN, Herbert. The German Experience with the Law of Affiliated Enterprises. In: HOPT, Klaus J. (Org.) Groups of companies in European Laws. Berlin: Walter de Gruyter, 1982. v. II.

WILLIAMSON, Oliver E. The Mechanisms of Governance, New York: Oxford University, 1996.

\section{Jurisprudência}

Acórdãos em que a desconsideração da personalidade jurídica nos grupos societários foi deferida

BRASIL. Supremo Tribunal de Justiça. Recurso Ordinário em Mandado de Segurança ${ }^{\circ}$ 12.872/SP, Terceira Turma, Rel. Ministra Nancy Andrighi, julgado em 24 de junho de 2002. Disponível em: <http://www.stj.jus.br>. Acesso em: 6 set 2010.

BRASIL. Supremo Tribunal de Justiça. Medida Cautelar n 15.526/SP, Rel. Min. Nancy Andrighi, Terceira Turma, julg. 22.09. 2009, v.u. Disponível em: <http://www.stj.jus.br>. Acesso em: 6 set 2010 .

BRASIL. Supremo Tribunal de Justiça. Recurso Especial no 1.071.643/DF, Rel. Min. Luis Felipe Salomão, Quarta Turma, julg. 02.04. 2009, v.u. Disponível em: <http://www.stj.jus.br>. Acesso em: 6 set 2010.

SÃO PAULO (estado). Tribunal de Justiça de São Paulo. Agravo de Instrumento ${ }^{\circ}$ 991.09.047387-7, Rel. Des. Simões de Vergueiro, 17ª Câmara de Direito Privado, julg. 30.06.2010, v.u. Disponível em: 〈http://www.tj.sp.gov.br〉. Acesso em: 17 ago. 2010.

SÃO PAULO (estado). Tribunal de Justiça de São Paulo. Apelação nº 992.07.060237-8, Rel. Des. Eros Piceli, 33 ${ }^{\text {a }}$ Câmara de Direito Privado, julg. 02.08.2010, v.u. Disponível em: <http://www.tj.sp.gov.br>. Acesso em: 17 ago. 2010. 
SÃO PAULO (estado). Tribunal de Justiça de São Paulo. Apelação no 992.07.038625-0, Rel. Des. Eros Piceli, 33 ${ }^{\text {a }}$ Câmara de Direito Privado, julg. 02.08.2010, v.u. Disponível em: <http://www.tj.sp.gov.br>. Acesso em: 17 ago. 2010.

SÃO PAULO (estado). Tribunal de Justiça de São Paulo. Agravo de Instrumento ${ }^{\circ}$ 990.10.021783-6, Rel. Des. Beretta da Silveira, $3^{\text {a }}$ Câmara de Direito Privado, julg. 13.07.2010, v.u. Disponível em: 〈http://www.tj.sp.gov.br>. Acesso em: 17 ago. 2010.

SÃO PAULO (estado). Tribunal de Justiça de São Paulo. Agravo de Instrumento $\mathrm{n}^{\mathrm{o}}$ 990.09.325026-8, Rel. Des. J. B. Franco de Godoi, 23ª Câmara de Direito Privado, julg.16.06.2010,v.u. Disponível em: <http://www.tj.sp.gov.br>. Acesso em: 17 ago. 2010.

SÃO PAULO (estado). Tribunal de Justiça de São Paulo. Agravo de Instrumento ${ }^{\circ}$ 990.09.300306-6, Rel. Des. Itamar Gaino, 21 a Câmara de Direito Privado, julg. 09.06.2010, v.u. Disponível em: 〈http://www.tj.sp.gov.br〉. Acesso em: 17 ago. 2010.

SÃO PAULO (estado). Tribunal de Justiça de São Paulo. Agravo de Instrumento ${ }^{\circ}$ 990.10.026791-4, Rel. Des. Itamar Gaino, 21 a Câmara de Direito Privado, julg. 09.06.2010, v.u. Disponível em: 〈http://www.tj.sp.gov.br〉. Acesso em: 17 ago. 2010.

SÃO PAULO (estado). Tribunal de Justiça de São Paulo. Apelação no 992.07.051646-3, Rel. Des. Eros Piceli, $33^{\text {a }}$ Câmara de Direito Privado, julg. 28.06.2010. v.u. Disponível em: <http://www.tj.sp.gov.br>. Acesso em: 17 ago. 2010.

SÃO PAULO (estado). Tribunal de Justiça de São Paulo. Agravo de Instrumento ${ }^{\circ}$ 990.10.048253-0, Rel. Des. Gomes Varjão, 34 ${ }^{\text {a }}$ Câmara de Direito Privado, julg. 14.06.2010, v.u. Disponível em: 〈http://www.tj.sp.gov.br〉. Acesso em: 17 ago. 2010.

SÃO PAULO (estado). Tribunal de Justiça de São Paulo. Agravo de Instrumento $\mathrm{n}^{\circ}$ 990.09.330647-6, Rel. Des. Cardoso Neto, 14 ${ }^{\text {a }}$ Câmara de Direito Privado, julg. 26.05.2010, v.u. Disponível em: 〈http://www.tj.sp.gov.br〉. Acesso em: 17 ago. 2010.

SÃO PAULO (estado). Tribunal de Justiça de São Paulo. Agravo de Instrumento ${ }^{\circ}$ 994.09.273080-0, Rel. Des. Erickson Gavazza Marques, 5ª Câmara de Direito Privado, julg. 02.06.2010, v.u. Disponível em: 〈http://www.tj.sp.gov.br〉. Acesso em: 17 ago. 2010.

SÃO PAULO (estado). Tribunal de Justiça de São Paulo. Agravo Regimental no 
990.10.150759-5/50000, Rel. Des. Matheus Fontes, 22a Câmara de Direito Privado, julg. 19.05.2010, v.u. Disponível em: <http://www.tj.sp.gov.br>. Acesso em: 17 ago. 2010.

SÃO PAULO (estado). Tribunal de Justiça de São Paulo. Agravo de Instrumento $\mathrm{n}^{\circ}$ 990.10.020638-9, Rel. Des. Beretta da Silveira, $3^{\text {a }}$ Câmara de Direito Privado, julg. 25.05.2010, v.u. Disponível em: 〈http://www.tj.sp.gov.br〉. Acesso em: 17 ago. 2010.

SÃO PAULO (estado). Tribunal de Justiça de São Paulo. Agravo de Instrumento ${ }^{\circ}$ 991.09.054569-0, Rel. Des. Pedro Ablas, 14ª Câmara de Direito Privado, julg. 12.05.2010, v.u. Disponível em: 〈http://www.tj.sp.gov.br〉. Acesso em: 17 ago. 2010.

SÃO PAULO (estado). Tribunal de Justiça de São Paulo. Agravo de Instrumento ${ }^{\circ}$ 990.09.318825-2, Rel. Des. Thiago de Siqueira, 14ª Câmara de Direito Privado, julg. 12.05.2010, v.u. Disponível em: <http://www.tj.sp.gov.br>. Acesso em: 17 ago. 2010.

SÃO PAULO (estado). Tribunal de Justiça de São Paulo. Agravo de Instrumento ${ }^{\circ}$ 994.09.271756-9, Rel. Des. Mauricio Vidigal, 10ª Câmara de Direito Privado, julg. 30.03.2010, v.u. Disponível em: 〈http://www.tj.sp.gov.br〉. Acesso em: 17 ago. 2010.

SÃO PAULO (estado). Tribunal de Justiça de São Paulo. Agravo de Instrumento $\mathrm{n}^{\circ}$ 994.09.273021-0, Rel. Des. Mauricio Vidigal, 10ª Câmara de Direito Privado, julg. 06.04.2010, v.u. Disponível em: 〈http://www.tj.sp.gov.br〉. Acesso em: 17 ago. 2010.

SÃO PAULO (estado). Tribunal de Justiça de São Paulo. Agravo de Instrumento ${ }^{\circ}$ 991.09.097733-6, Rel. Des. Jovino de Sylos, 16 Câmara de Direito Privado, julg. 09.03.2010, v.m. Disponível em: 〈http://www.tj.sp.gov.br>. Acesso em: 17 ago. 2010.

SÃO PAULO (estado). Tribunal de Justiça de São Paulo. Agravo de Instrumento ${ }^{\circ}$ 990.09.359756-0, Rel. Des. Jovino de Sylos, 16 ${ }^{\text {a }}$ Câmara de Direito Privado, julg. 16.03.2010, v.u. Disponível em: 〈http://www.tj.sp.gov.br>. Acesso em: 17 ago. 2010.

SÃO PAULO (estado). Tribunal de Justiça de São Paulo. Apelação nº 992.08.025402-0, Rel. Des. Kioitsi Chicuta, 32 ${ }^{\text {a }}$ Câmara de Direito Privado, julg. 15.04.2010, v.u. Disponível em: <http://www.tj.sp.gov.br>. Acesso em: 17 ago. 2010.

SÃO PAULO (estado). Tribunal de Justiça de São Paulo. Agravo de Instrumento ${ }^{\circ}$ 990.09.321946-8, Rel. Des. Souza Geishofer, 16ª Câmara de Direito Privado, 
julg.30.03.2010, v.u. Disponível em: 〈http://www.tj.sp.gov.br〉. Acesso em: 17 ago. 2010.

SÃO PAULO (estado). Tribunal de Justiça de São Paulo. Agravo de Instrumento ${ }^{\circ}$ 991.09.047070-3, Rel Des. Cauduro Padin, 13 a Câmara de Direito Privado, julg. 24.02.2010, v.u. Disponível em: 〈http://www.tj.sp.gov.br>. Acesso em: 17 ago. 2010.

SÃO PAULO (estado). Tribunal de Justiça de São Paulo. Agravo de Instrumento ${ }^{\circ}$ 992.07.044680-5, Rel. Des. Beatriz Braga, 27 Câmara de Direito Privado, julg. 09.03.2010, v.u. Disponível em: 〈http://www.tj.sp.gov.br〉. Acesso em: 17 ago. 2010.

SÃO PAULO (estado). Tribunal de Justiça de São Paulo. Agravo de Instrumento $\mathrm{n}^{\circ}$ 991.09.041164-2, Rel. Des. Eduardo Siqueira, 37ª Câmara de Direito Privado, julg. 03.03.2010, v.u. Disponível em: 〈http://www.tj.sp.gov.br〉. Acesso em: 17 ago. 2010.

SÃO PAULO (estado). Tribunal de Justiça de São Paulo. Agravo de Instrumento ${ }^{\circ}$ 991.09.047291-9, Rel. Des. Ricardo Negrão, 19a Câmara de Direito Privado, julg. 26.01.2010, v.u. Disponível em: <http://www.tj.sp.gov.br>. Acesso em: 17 ago. 2010.

SÃO PAULO (estado). Tribunal de Justiça de São Paulo. Agravo de Instrumento $\mathrm{n}^{\mathrm{o}}$ 991.09.040913-3, Rel. Des. Edgard Jorge Lauand, 15ª Câmara de Direito Privado, julg. 28.01.2010, v.u. Disponível em: 〈http://www.tj.sp.gov.br>. Acesso em: 17 ago. 2010.

SÃO PAULO (estado). Tribunal de Justiça de São Paulo. Agravo de Instrumento ${ }^{\circ}$ 990.09.306575-4, Rel. Des. Soares Levada, 11 a Câmara de Direito Privado, julg. 21.01.2010, v.u. Disponível em: 〈http://www.tj.sp.gov.br〉. Acesso em: 17 ago. 2010.

SÃO PAULO (estado). Tribunal de Justiça de São Paulo. Apelação nº 992.06.011239-4, Rel. Des. Júlio Vidal, $28^{\text {a }}$ Câmara de Direito Privado, julg. 15.12.2009, v.u. Disponível em: <http://www.tj.sp.gov.br>. Acesso em: 17 ago. 2010.

SÃO PAULO (estado). Tribunal de Justiça de São Paulo. Agravo de Instrumento ${ }^{\circ}$ 7.372.269-1, Rel. Des. Correia Lima, 20ª Câmara de Direito Privado, julg. 09.11.2009, v.u. Disponível em: <http://www.tj.sp.gov.br>. Acesso em: 17 ago. 2010.

SÃO PAULO (estado). Tribunal de Justiça de São Paulo. Agravo de Instrumento ${ }^{\circ}$ 991.09.039676-7, Rel. Des. Edgard Jorge Lauand, 15ª Câmara de Direito Privado, julg. 24.11.2009, v.u. Disponível em: 〈http://www.tj.sp.gov.br〉. Acesso em: 17 ago. 2010. 
SÃO PAULO (estado). Tribunal de Justiça de São Paulo. Agravo de Instrumento ${ }^{\circ}$ 992.09.042952-3, Rel. Des. Ricardo Pessoa de Mello Belli, 25 a Câmara de Direito Privado, julg. 21.10.2009, v.u. Disponível em: 〈http://www.tj.sp.gov.br〉. Acesso em: 17 ago. 2010.

SÃO PAULO (estado). Tribunal de Justiça de São Paulo. Apelação no 992.07.052067-3, Rel. Des. Marcos Ramos, $30^{\text {a }}$ Câmara de Direito Privado, julg. 07.10.2009, v.u. Disponível em: <http://www.tj.sp.gov.br>. Acesso em: 17 ago. 2010.

SÃO PAULO (estado). Tribunal de Justiça de São Paulo. Apelação sem Revisão n ${ }^{o}$ 1062847-0/3, Rel. Des. Pedro Baccarat, 36a Câmara de Direito Privado, julg. 03.09.2009, v.u. Disponível em: 〈http://www.tj.sp.gov.br>. Acesso em: 17 ago. 2010.

SÃO PAULO (estado). Tribunal de Justiça de São Paulo. Agravo de Instrumento ${ }^{\circ}$ 1278814-0/0, Rel. Des. Gomes Varjão, 34ª Câmara de Direito Privado, julg. 17.08.2009, v.u. Disponível em: 〈http://www.tj.sp.gov.br>. Acesso em: 17 ago. 2010.

SÃO PAULO (estado). Tribunal de Justiça de São Paulo. Agravo de Instrumento ${ }^{\circ}$ 620.695-4/6, Rel. Des. Maia da Cunha, 4ª Câmara de Direito Privado, Julg. 03.09.2009, v.u. Disponível em: 〈http://www.tj.sp.gov.br>. Acesso em: 17 ago. 2010.

SÃO PAULO (estado). Tribunal de Justiça de São Paulo. Apelação Cível com Revisão n 628.087-4/0-00, Rel. Des. Adilson de Andrade, $3^{\text {a }}$ Câmara de Direito Privado, julg. 01.09.2009, v.u. Disponível em: 〈http://www.tj.sp.gov.br〉. Acesso em: 17 ago. 2010.

SÃO PAULO (estado). Tribunal de Justiça de São Paulo. Agravo de Instrumento ${ }^{\circ}$ 1258245-0/0, Rel. Des. José Malerbi, 35ª Câmara de Direito Privado, julg. 20.07.2009, v.u. Disponível em: <http://www.tj.sp.gov.br>. Acesso em: 17 ago. 2010.

SÃO PAULO (estado). Tribunal de Justiça de São Paulo. Agravo de Instrumento ${ }^{\circ}$ 7.312.580-7, Rel. Des. Itamar Gaino, $21^{\text {a }}$ Câmara de Direito Privado, julg. 24.06.2009, v.u. Disponível em: <http://www.tj.sp.gov.br>. Acesso em: 17 ago. 2010.

SÃO PAULO (estado). Tribunal de Justiça de São Paulo. Agravo de Instrumento ${ }^{\circ}$ 7340694-7, Rel. Des. Thiago de Siqueira, 14ª Câmara de Direito Privado, julg. 27.05. 2009, v.u. Disponível em: <http://www.tj.sp.gov.br>. Acesso em: 17 ago. 2010.

SÃO PAULO (estado). Tribunal de Justiça de São Paulo. Agravo de Instrumento ${ }^{\circ}$ 
1230908-0/6, Rel. Des. Berenice Marcondes Cesar, 27ª Câmara de Direito Privado, julg. 28.04.2009, m.v. Disponível em: 〈http://www.tj.sp.gov.br>. Acesso em: 17 ago. 2010.

SÃO PAULO (estado). Tribunal de Justiça de São Paulo. Agravo de Instrumento ${ }^{\circ}$ 587.310-4/1-00, Rel. Des. Elliot Akel, $1^{\text {a }}$ Câmara de Direito Privado, julg. 02.06.2009, v.u. Disponível em: <http://www.tj.sp.gov.br>. Acesso em: 17 ago. 2010.

SÃO PAULO (estado). Tribunal de Justiça de São Paulo. Agravo de Instrumento ${ }^{\circ}$ 7.332.763-2, Rel. Des. João Camillo de Almeida Prado Costa, 19ª Câmara de Direito Privado, julg. 30.03.2009, v.u. Disponível em: <http://www.tj.sp.gov.br>. Acesso em: 17 ago. 2010 .

SÃO PAULO (estado). Tribunal de Justiça de São Paulo. Agravo de Instrumento ${ }^{\circ}$ 1240323-0/1, Rel. Des. Melo Bueno, 35 Câmara de Direito Privado, julg. 30.03.2009, v.u. Disponível em: <http://www.tj.sp.gov.br>. Acesso em: 17 ago. 2010.

SÃO PAULO (estado). Tribunal de Justiça de São Paulo. Agravo de Instrumento ${ }^{\circ}$ 1250487-0/6, Rel. Des. Gomes Varjão, 34ª Câmara de Direito Privado, julg. 02.03.2009, v.u. Disponível em: 〈http://www.tj.sp.gov.br>. Acesso em: 17 ago. 2010.

SÃO PAULO (estado). Tribunal de Justiça de São Paulo. Agravo de Instrumento ${ }^{\circ}$ 1233799-0/9, Rel. Des. Adilson de Araujo, 31 a Câmara de Direito Privado, julg. 03.03.2009, v.u. Disponível em: 〈http://www.tj.sp.gov.br〉. Acesso em: 17 ago. 2010.

SÃO PAULO (estado). Tribunal de Justiça de São Paulo. Apelação Cível com Revisão n ${ }^{\circ}$ 516.507-4/6-00, Rel. Des. Jesus Lofrano, $3^{\mathrm{a}}$ Câmara de Direito Privado, julg. 17.03.2009, v.u. Disponível em: <http://www.tj.sp.gov.br>. Acesso em: 17 ago. 2010.

SÃO PAULO (estado). Tribunal de Justiça de São Paulo. Agravo de Instrumento $\mathrm{n}^{\circ}$ 569.212-4/2-00, Rel. Des. Elliot Akel, $1^{\text {a }}$ Câmara de Direito Privado, julg. 03.03.2009, v.u. Disponível em: 〈http://www.tj.sp.gov.br>. Acesso em: 17 ago. 2010.

SÃO PAULO (estado). Tribunal de Justiça de São Paulo. Agravo de Instrumento ${ }^{\circ}$ 573.248-4/0-00, Rel. Des. Elliot Akel, $1^{\text {a }}$ Câmara de Direito Privado, julg. 03.02.2009, v.u. Disponível em: <http://www.tj.sp.gov.br>. Acesso em: 17 ago. 2010.

SÃO PAULO (estado). Tribunal de Justiça de São Paulo. Apelação com Revisão no 
1234947-0/6, Rel. Des. Artur Marques, 35ª Câmara de Direito Privado, julg. 02.02.2009, v.u. Disponível em: <http://www.tj.sp.gov.br〉. Acesso em: 17 ago. 2010.

SÃO PAULO (estado). Tribunal de Justiça de São Paulo. Agravo de Instrumento ${ }^{\circ}$ 1214586-0/4, Rel. Des. Francisco Occhiuto Junior, 32 ${ }^{\mathrm{a}}$ Câmara de Direito Privado, julg. 15.01.2009, v.u. Disponível em: 〈http://www.tj.sp.gov.br〉. Acesso em: 17 ago. 2010.

SÃO PAULO (estado). Tribunal de Justiça de São Paulo. Agravo de Instrumento ${ }^{\circ}$ 7166716-4, Rel. Des. Térsio Negrato, $17^{\text {a }}$ Câmara de Direito Privado, julg. 1.12.2008, v.u. Disponível em: 〈http://www.tj.sp.gov.br〉. Acesso em: 17 ago. 2010.

SÃO PAULO (estado). Tribunal de Justiça de São Paulo. Agravo de Instrumento ${ }^{\circ}$

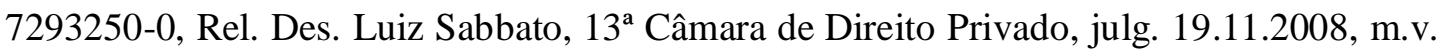
Disponível em: <http://www.tj.sp.gov.br>. Acesso em: 17 ago. 2010.

SÃO PAULO (estado). Tribunal de Justiça de São Paulo. Agravo de Instrumento ${ }^{\circ}$ 1229723-0/6, Rel. Des. Ricardo Pessoa de Mello Belli, 25ª Câmara de Direito Privado, julg. 02.12.2008, v.u. Disponível em: 〈http://www.tj.sp.gov.br〉. Acesso em: 17 ago. 2010.

SÃO PAULO (estado). Tribunal de Justiça de São Paulo. Agravo de Instrumento $\mathrm{n}^{\circ}$ 1198103-0/0, Rel. Des. Pereira Calças, 29ª Câmara de Direito Privado, julg. 26.11.2008, v.u. Disponível em: 〈http://www.tj.sp.gov.br〉. Acesso em: 17 ago. 2010.

SÃO PAULO (estado). Tribunal de Justiça de São Paulo. Agravo de Instrumento ${ }^{\circ}$ 584.750-4/7-00, Rel. Des. Pereira Calças, Câmara Especial de Falências e Recuperações Judiciais de Direito Privado, julg.29.10.2008, v.u. Disponível em: <http://www.tj.sp.gov.br>. Acesso em: 17 ago. 2010.

SÃO PAULO (estado). Tribunal de Justiça de São Paulo. Agravo de Instrumento ${ }^{\circ}$ 557.843-4/9-00, Rel. Des. Elliot Akel, $1^{\text {a }}$ Câmara de Direito Privado, julg. 14.10.2008, v.u. Disponível em: <http://www.tj.sp.gov.br>. Acesso em: 17 ago. 2010.

SÃO PAULO (estado). Tribunal de Justiça de São Paulo. Agravo de Instrumento ${ }^{\circ}$ 7.284.496-7, Rel. Des. Ribeiro de Souza, 12a Câmara de Direito Privado julg. 17.09.2008, v.u. Disponível em: 〈http://www.tj.sp.gov.br>. Acesso em: 17 ago. 2010.

SÃO PAULO (estado). Tribunal de Justiça de São Paulo. Agravo de Instrumento ${ }^{\circ}$ 
531.742-4/8-00, Rel. Des. Elliot Akel, $1^{a}$ Câmara de Direito Privado, julg. 30.09.2008, v.u. Disponível em: <http://www.tj.sp.gov.br>. Acesso em: 17 ago. 2010.

SÃO PAULO (estado). Tribunal de Justiça de São Paulo. Agravo de Instrumento ${ }^{\circ}$ 532.684-4/0-00, Rel. Des. Elliot Akel, $1^{\text {a }}$ Câmara de Direito Privado, julg. 30.09.2008, v.u. Disponível em: <http://www.tj.sp.gov.br>. Acesso em: 17 ago. 2010.

SÃO PAULO (estado). Tribunal de Justiça de São Paulo. Agravo de Instrumento ${ }^{\circ}$ 558.430-4/1-00, Rel. Des. Elliot Akel, $1^{\text {a }}$ Câmara de Direito Privado, julg. 30.09.2008, v.u. Disponível em: 〈http://www.tj.sp.gov.br〉. Acesso em: 17 ago. 2010.

SÃO PAULO (estado). Tribunal de Justiça de São Paulo. Agravo de Instrumento ${ }^{\circ}$ 534.544-4/6-00, Rel. Des. Elliot Akel, $1^{\text {a }}$ Câmara de Direito Privado, julg. 23.09.2008, v.u. Disponível em: <http://www.tj.sp.gov.br>. Acesso em: 17 ago. 2010.

SÃO PAULO (estado). Tribunal de Justiça de São Paulo. Agravo de Instrumento ${ }^{\circ}$ 1179386-0/0, Rel. Des. Vanderci Álvares, 25 $5^{\text {a }}$ Camara de Direito Privado, julg. 23.09.2008, v.u. Disponível em: <http://www.tj.sp.gov.br>. Acesso em: 17 ago. 2010.

SÃO PAULO (estado). Tribunal de Justiça de São Paulo. Agravo de Instrumento $\mathrm{n}^{\circ}$ 555.413-4/2-00, Rel. Des. Elliot Akel, 1 a Câmara de Direito Privado, julg. 23.09.2008, v.u. Disponível em: <http://www.tj.sp.gov.br>. Acesso em: 17 ago. 2010.

SÃO PAULO (estado). Tribunal de Justiça de São Paulo. Apelação Cível com Revisão n 509.001-4/0-00, Rel. Des. Salles Rossi, 8 a Câmara de Direito Privado, julg. 17.09.2008, v.u. Disponível em: 〈http://www.tj.sp.gov.br>. Acesso em: 17 ago. 2010.

SÃO PAULO (estado). Tribunal de Justiça de São Paulo. Agravo de Instrumento ${ }^{\circ}$ 532.490-4/4-00, Rel. Des. Elliot Akel, $1^{\text {a }}$ Câmara de Direito Privado, julg. 16.09.2008, v.u. Disponível em: 〈http://www.tj.sp.gov.br〉. Acesso em: 17 ago. 2010.

SÃO PAULO (estado). Tribunal de Justiça de São Paulo. Agravo de Instrumento ${ }^{\circ}$ 521.791-4/2-00, Rel. Des. Romeu Ricupero, Câmara Especial de Falências e Recuperações Judiciais de Direito Privado, julg. 27.08.2008, v.m. Disponível em: <http://www.tj.sp.gov.br>. Acesso em: 17 ago. 2010.

SÃO PAULO (estado). Tribunal de Justiça de São Paulo. Agravo de Instrumento ${ }^{\circ}$ 
553.068-4/2-00, Rel. Des. Romeu Ricupero, Câmara Especial de Falências e Recuperações Judiciais de Direito Privado, julg. 27.08.2008, v.m. Disponível em: <http://www.tj.sp.gov.br>. Acesso em: 17 ago. 2010.

SÃO PAULO (estado). Tribunal de Justiça de São Paulo. Agravo de Instrumento ${ }^{\circ}$ 531.568-4/3-00, Rel. Des. Elliot Akel, $1^{\text {a }}$ Câmara de Direito Privado, julg. 09.09.2008, v.u. Disponível em: <http://www.tj.sp.gov.br>. Acesso em: 17 ago. 2010.

SÃO PAULO (estado). Tribunal de Justiça de São Paulo. Agravo de Instrumento $\mathrm{n}^{\mathrm{o}}$ 540.419-4/5-00, Rel. Des. Elliot Akel, 1 a Câmara de Direito Privado, julg. 09.09.2008, v.u. Disponível em: <http://www.tj.sp.gov.br>. Acesso em: 17 ago. 2010.

SÃO PAULO (estado). Tribunal de Justiça de São Paulo. Agravo de Instrumento ${ }^{\circ}$ 533.754-4/7-00, Rel. Des. Elliot Akel, $1^{\text {a }}$ Câmara de Direito Privado, julg. 09.09.2008, v.u. Disponível em: <http://www.tj.sp.gov.br>. Acesso em: 17 ago. 2010.

SÃO PAULO (estado). Tribunal de Justiça de São Paulo. Agravo de Instrumento $\mathrm{n}^{\mathrm{o}}$ 7.260.924-4, Rel. Des. Ligia Araújo Bisogni, 14ª Câmara de Direito Privado, julg. 06.08.2008, v.u. Disponível em: <http://www.tj.sp.gov.br>. Acesso em: 17 ago. 2010.

SÃO PAULO (estado). Tribunal de Justiça de São Paulo. Agravo de Instrumento ${ }^{\circ}$ 563.612-4/4-00, Rel. Des. Pereira Calças, Câmara Especial de Falências e Recuperações Judiciais de Direito Privado, julg. 27.08.2008, v.u. Disponível em: <http://www.tj.sp.gov.br>. Acesso em: 17 ago. 2010.

SÃO PAULO (estado). Tribunal de Justiça de São Paulo. Apelação Cível com Revisão no 567.089-4/5-00, Rel. Des. Adilson de Andrade, $3^{\text {a }}$ Câmara de Direito Privado, julg. 26.08.2008, v.u. Disponível em: 〈http://www.tj.sp.gov.br〉. Acesso em: 17 ago. 2010.

SÃO PAULO (estado). Tribunal de Justiça de São Paulo. Agravo de Instrumento ${ }^{\circ}$ 1199436-0/8, Rel. Des. José Malerbi, 35ª Câmara de Direito Privado, julg. 25.08.2008, v.u. Disponível em: <http://www.tj.sp.gov.br>. Acesso em: 17 ago. 2010.

SÃO PAULO (estado). Tribunal de Justiça de São Paulo. Agravo de Instrumento ${ }^{\circ}$ 533.206-4/7-00, Rel. Des. Elliot Akel, $1^{a}$ Câmara de Direito Privado, julg. 12.08.2008, v.u. Disponível em: 〈http://www.tj.sp.gov.br〉. Acesso em: 17 ago. 2010. 
SÃO PAULO (estado). Tribunal de Justiça de São Paulo. Agravo de Instrumento $\mathrm{n}^{\mathrm{o}}$ 7244658-5, Rel. Des. Ricardo Negrão, 19ª Câmara de Direito Privado, julg. 09.06.2008, v.u. Disponível em: 〈http://www.tj.sp.gov.br>. Acesso em: 17 ago. 2010.

SÃO PAULO (estado). Tribunal de Justiça de São Paulo. Agravo de Instrumento ${ }^{\circ}$ 531.570-4/2-00, Rel. Des. Elliot Akel, $1^{\text {a }}$ Câmara de Direito Privado, julg. 17.06.2008, v.u. Disponível em: <http://www.tj.sp.gov.br>. Acesso em: 17 ago. 2010.

SÃO PAULO (estado). Tribunal de Justiça de São Paulo. Agravo de Instrumento $\mathrm{n}^{\mathrm{o}}$ 7.207.506-6, Rel. Des. Roberto Bedaque, 22 a Câmara de Direito Privado, julg. 03.06.2008, v.u. Disponível em: 〈http://www.tj.sp.gov.br〉. Acesso em: 17 ago. 2010.

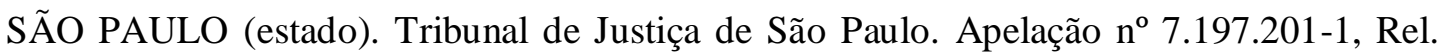
Des. Virgilio de Oliveira Junior, 14ª Câmara de Direito Privado, julg. 14.05.2008, v.u. Disponível em: <http://www.tj.sp.gov.br>. Acesso em: 17 ago. 2010.

SÃO PAULO (estado). Tribunal de Justiça de São Paulo. Agravo de Instrumento $\mathrm{n}^{\circ}$ 7239618-8, Rel. Des. Térsio Negrato, $17^{\text {a }}$ Câmara de Direito Privado, julg. 7.05.2008, v.u. Disponível em: <http://www.tj.sp.gov.br>. Acesso em: 17 ago. 2010.

SÃO PAULO (estado). Tribunal de Justiça de São Paulo. Agravo de Instrumento $\mathrm{n}^{\circ}$ 1167138-0/4, Rel. Des. Gomes Varjão, 34ª Câmara de Direito Privado, julg. 14.05.2008, v.u. Disponível em: 〈http://www.tj.sp.gov.br>. Acesso em: 17 ago. 2010.

SÃO PAULO (estado). Tribunal de Justiça de São Paulo. Agravo de Instrumento ${ }^{\circ}$ 7.216.715-4, Rel. Des. Waldir de Souza José, $15^{\mathrm{a}}$ Câmara de Direito Privado, julg. 06.05.2008, v.u. Disponível em: <http://www.tj.sp.gov.br>. Acesso em: 17 ago. 2010.

SÃO PAULO (estado). Tribunal de Justiça de São Paulo. Agravo de Instrumento $\mathrm{n}^{\circ}$ 7.221.111-9, Rel. Des. Sebastião Alves Junqueira, $19^{a}$ Câmara de Direito Privado, julg. 15.04.2008, v.u. Disponível em: 〈http://www.tj.sp.gov.br〉. Acesso em: 17 ago. 2010.

SÃO PAULO (estado). Tribunal de Justiça de São Paulo. Agravo de Instrumento ${ }^{\circ}$ 555.760-4/5-00, Rel. Des. Piva Rodrigues, $9^{\text {a }}$ Câmara de Direito Privado, julg. 08.04.2008, v.u. Disponível em: <http://www.tj.sp.gov.br>. Acesso em: 17 ago. 2010.

SÃO PAULO (estado). Tribunal de Justiça de São Paulo. Apelação com Revisão no 
706251-0/3, Rel. Des. Berenice Marcondes Cesar, 27 Câmara de Direito Privado, julg. 25.03.2008, v.u. Disponível em: 〈http://www.tj.sp.gov.br〉. Acesso em: 17 ago. 2010.

SÃO PAULO (estado). Tribunal de Justiça de São Paulo. Agravo de Instrumento $\mathrm{n}^{\circ}$ 1155497-0/4, Rel. Des. Luis de Carvalho, 29ª Câmara de Direito Privado, julg. 23.04.2008, v.u. Disponível em: 〈http://www.tj.sp.gov.br>. Acesso em: 17 ago. 2010.

SÃO PAULO (estado). Tribunal de Justiça de São Paulo. Agravo de Instrumento $\mathrm{n}^{\mathrm{o}}$ 1109634-0/6, Rel. Des. Ferraz Felisardo, 29ª Câmara de Direito Privado, julg. 27.02.2008, v.u. Disponível em: <http://www.tj.sp.gov.br>. Acesso em: 17 ago. 2010.

SÃO PAULO (estado). Tribunal de Justiça de São Paulo. Agravo de Instrumento ${ }^{\circ}$ 537.949-4/6-00, Rel. Des. Elliot Akel, $1^{\text {a }}$ Câmara de Direito Privado, julg. 01.04.2008, v.u. Disponível em: <http://www.tj.sp.gov.br>. Acesso em: 17 ago. 2010.

SÃO PAULO (estado). Tribunal de Justiça de São Paulo. Agravo de Instrumento ${ }^{\circ}$ 1153854-0/4, Rel. Des. Pereira Calças, 29a Câmara de Direito Privado, jul. 26.03.2008, v.u. Disponível em: <http://www.tj.sp.gov.br>. Acesso em: 17 ago. 2010.

SÃO PAULO (estado). Tribunal de Justiça de São Paulo. Agravo de Instrumento $\mathrm{n}^{\circ}$ 532.479-4/4-00, Rel. Des. Elliot Akel, $1^{a}$ Câmara de Direito Privado, julg. 18.03.2008, v.u. Disponível em: <http://www.tj.sp.gov.br>. Acesso em: 17 ago. 2010.

SÃO PAULO (estado). Tribunal de Justiça de São Paulo. Agravo de Instrumento ${ }^{\circ}$ 7166716-4, Rel. Des. Térsio Negrato, 17ª Câmara de Direito Privado, julg. 17.10.2007, v.u. Disponível em: <http://www.tj.sp.gov.br>. Acesso em: 17 ago. 2010.

SÃO PAULO (estado). Tribunal de Justiça de São Paulo. Agravo de Instrumento $\mathrm{n}^{\mathrm{o}}$ 1141957-0/0, Rel. Des. Sá Moreira de Oliveira, 33ª Câmara de Direito Privado, julg. 12.12.2007, v.u. Disponível em: 〈http://www.tj.sp.gov.br>. Acesso em: 17 ago. 2010.

SÃO PAULO (estado). Tribunal de Justiça de São Paulo. Agravo de Instrumento ${ }^{\circ}$ 1137722-0/9, Rel. Des. Manoel Justino Bezerra Filho, 35ª Câmara de Direito Privado, julg. 17.12.2007, v.u. Disponível em: 〈http://www.tj.sp.gov.br〉. Acesso em: 17 ago. 2010.

SÃO PAULO (estado). Tribunal de Justiça de São Paulo. Agravo de Instrumento ${ }^{\circ}$ 1141418-0/9, Rel. Des. Arantes Theodoro, 36 ${ }^{\mathrm{a}}$ Câmara de Direito Privado, julg. 
14.12.2007, v.u. Disponível em: 〈http://www.tj.sp.gov.br〉. Acesso em: 17 ago. 2010.

SÃO PAULO (estado). Tribunal de Justiça de São Paulo. Embargos Declaratórios ${ }^{\circ}$ 1116530-1/6, Rel. Des. Gomes Varjão, 34ª Câmera de Direito Privado, julg. 12.11.07, v.u. Disponível em: <http://www.tj.sp.gov.br>. Acesso em: 17 ago. 2010.

SÃO PAULO (estado). Tribunal de Justiça de São Paulo. Embargos de Declaração n ${ }^{\circ}$ 443.149-4/7-01, Rel. Des. Silvério Ribeiro, 5 Câmara de Direito Privado, julg. 14.11.2007, v.u. Disponível em: <http://www.tj.sp.gov.br>. Acesso em: 17 ago. 2010.

SÃO PAULO (estado). Tribunal de Justiça de São Paulo. Agravo de Instrumento $\mathrm{n}^{\circ}$ 507.818-4/4-00, Rel. Des. Elliot Akel, $1^{a}$ Câmara de Direito Privado, julg. 13.11.2007, v.u. Disponível em: <http://www.tj.sp.gov.br>. Acesso em: 17 ago. 2010.

SÃO PAULO (estado). Tribunal de Justiça de São Paulo. Apelação com Revisão no 829328-0/2, Rel. Des. Cambrea Filho, 27ª Câmara de Direito Privado, julg. 30.10.2007, v.u. Disponível em: <http://www.tj.sp.gov.br>. Acesso em: 17 ago. 2010.

SÃO PAULO (estado). Tribunal de Justiça de São Paulo. Agravo de Instrumento $\mathrm{n}^{\mathrm{o}}$ 7.109.345-9, Rel. Des. Mário de Oliveira, 14 ${ }^{\mathrm{a}}$ Câmara de Direito Privado, julg. 17.10.2007, v.u. Disponível em: <http://www.tj.sp.gov.br>. Acesso em: 17 ago. 2010.

SÃO PAULO (estado). Tribunal de Justiça de São Paulo. Apelação Cível com Revisão n ${ }^{\circ}$ 296.933-4/8-00, Rel. Des. Adilson de Andrade, $3^{\text {a }}$ Câmara de Direito Privado, julg. 23.10.2007, v.u. Disponível em: 〈http://www.tj.sp.gov.br>. Acesso em: 17 ago. 2010.

SÃO PAULO (estado). Tribunal de Justiça de São Paulo. Agravo de Instrumento $\mathrm{n}^{\mathrm{o}}$ 1116530-0/4, Rel. Des. Gomes Varjão, 34ª Câmara de Direito Privado, julg, 12.09.2007, v.u. Disponível em: <http://www.tj.sp.gov.br>. Acesso em: 17 ago. 2010.

SÃO PAULO (estado). Tribunal de Justiça de São Paulo. Agravo de Instrumento ${ }^{\circ}$ 497.422-4/1-00, Rel. Des. Romeu Ricupero, Câmara Especial de Falências e Recuperações Judiciais de Direito Privado, julg. 29.08.2007, v.u. Disponível em: <http://www.tj.sp.gov.br>. Acesso em: 17 ago. 2010.

SÃO PAULO (estado). Tribunal de Justiça de São Paulo. Agravo de Instrumento ${ }^{\circ}$ 1120040-0/0, Rel. Des. Arantes Theodoro, 36ª Câmara de Direito Privado, julg. 16.08.07, 
v.u. Disponível em: <http://www.tj.sp.gov.br>. Acesso em: 17 ago. 2010.

SÃO PAULO (estado). Tribunal de Justiça de São Paulo. Agravo de Instrumento ${ }^{\circ}$ 7152981-2, Rel. Des. Soares Levada, $11^{\text {a }}$ Câmara de Direito Privado, julg. 02.08.2007, v.u. Disponível em: <http://www.tj.sp.gov.br>. Acesso em: 17 ago. 2010.

SÃO PAULO (estado). Tribunal de Justiça de São Paulo. Apelação com Revisão n ${ }^{\circ}$ 1097503-0/8, Rel. Des. Campos Petroni, 27ª Câmara de Direito Privado, julg. 07.08.2007, v.u. Disponível em: <http://www.tj.sp.gov.br>. Acesso em: 17 ago. 2010.

SÃO PAULO (estado). Tribunal de Justiça de São Paulo. Apelação Cível com Revisão n ${ }^{\circ}$ 459.764-4/3-00, Rel. Des. Carlos Stroppa, 9 $9^{\text {a }}$ Camara de Direito Privado, julg. 19.06.2007, v.u. Disponível em: <http://www.tj.sp.gov.br>. Acesso em: 17 ago. 2010.

SÃO PAULO (estado). Tribunal de Justiça de São Paulo. Agravo de Instrumento ${ }^{\circ}$ 7146792-8, Rel. Des. Soares Levada, $11^{\text {a }}$ Câmara de Direito Privado, Julg. 28.06.2007, v.u. Disponível em: <http://www.tj.sp.gov.br>. Acesso em: 17 ago. 2010.

SÃO PAULO (estado). Tribunal de Justiça de São Paulo. Agravo de Instrumento $\mathrm{n}^{\mathrm{o}}$ 469.965-4/9-00, Rel. Des. Elliot Akel, $1^{a}$ Câmara de Direito Privado, julg. 22.05.2007, v.u. Disponível em: <http://www.tj.sp.gov.br>. Acesso em: 17 ago. 2010.

SÃO PAULO (estado). Tribunal de Justiça de São Paulo. Apelação no 7.082.437-6, Rel. Des. Sebastião Alves Junqueira, 19ª Câmara de Direito Privado, julg. 08.05.2007, v.u. Disponível em: 〈http://www.tj.sp.gov.br〉. Acesso em: 17 ago. 2010.

SÃO PAULO (estado). Tribunal de Justiça de São Paulo. Agravo de Instrumento $\mathrm{n}^{\mathrm{o}}$ 471.284-4/0, Rel. Des. Mauricio Vidigal, 10ª Câmara de Direito Privado, julg. 17.04.2007, v.u. Disponível em: <http://www.tj.sp.gov.br>. Acesso em: 17 ago. 2010.

SÃO PAULO (estado). Tribunal de Justiça de São Paulo. Agravo de Instrumento ${ }^{\circ}$ 7.114.371-2, Rel. Des. Elmano de Oliveira, 17 Câmara de Direito Privado, julg. 11.04.2007, v.u. Disponível em: 〈http://www.tj.sp.gov.br〉. Acesso em: 17 ago. 2010.

SÃO PAULO (estado). Tribunal de Justiça de São Paulo. Agravo de Instrumento ${ }^{\circ}$ 475.195-4/3-00, Rel. Des. José Roberto Lino Machado, Câmara Especial de Falências e Recuperações Judiciais de Direito Privado, julg. 25.04.2007, v.u. Disponível em: 
<http://www.tj.sp.gov.br>. Acesso em: 17 ago. 2010.

SÃO PAULO (estado). Tribunal de Justiça de São Paulo. Agravo de Instrumento ${ }^{\circ}$

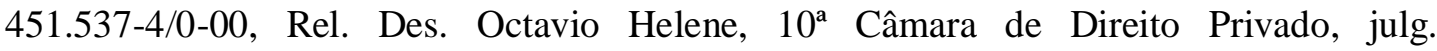
24.04.2007, v.u. Disponível em: 〈http://www.tj.sp.gov.br>. Acesso em: 17 ago. 2010.

SÃO PAULO (estado). Tribunal de Justiça de São Paulo. Agravo de Instrumento ${ }^{\circ}$ 7.127.966-6, Rel. Des. Tersio José Negrato, 17 Câmara de Direito Privado, Julg. 11.04.2007, v.u. Disponível em: 〈http://www.tj.sp.gov.br〉. Acesso em: 17 ago. 2010.

SÃO PAULO (estado). Tribunal de Justiça de São Paulo. Apelação Cível com Revisão ${ }^{\circ}$ 348.246-4/5-00, Rel. Des. Adilson de Andrade, $3^{\mathrm{a}}$ Câmara de Direito Privado, Julg. 27.03.2007, v.u. Disponível em: 〈http://www.tj.sp.gov.br>. Acesso em: 17 ago. 2010.

SÃO PAULO (estado). Tribunal de Justiça de São Paulo. Agravo de Instrumento ${ }^{\circ}$ 7.117.092-8, Rel. Des. Itamar Gaino, 21 a Câmara de Direito Privado, julg. 07.03.2007, v.u. Disponível em: <http://www.tj.sp.gov.br>. Acesso em: 17 ago. 2010.

SÃO PAULO (estado). Tribunal de Justiça de São Paulo. Agravo de Instrumento $\mathrm{n}^{\mathrm{o}}$ 7.117.092-8, Rel. Des. Itamar Gaino, 21 a Câmara de Direito Privado, julg. 07.03.2007, v.u. Disponível em: <http://www.tj.sp.gov.br>. Acesso em: 17 ago. 2010.

SÃO PAULO (estado). Tribunal de Justiça de São Paulo. Agravo de Instrumento ${ }^{\circ}$ 465.398-4/1-00, Rel. Des. A. C. Mathias Coltro, 5 ${ }^{\text {a }}$ Câmara de Direito Privado, julg. 28.02.2007, v.u. Disponível em: 〈http://www.tj.sp.gov.br>. Acesso em: 17 ago. 2010.

TJSP, Agravo de Instrumento $\mathrm{n}^{\mathrm{o}}$ 465.460-4/5-00, Rel. Des. A. C. Mathias Coltro, $5^{\mathrm{a}}$ Câmara de Direito Privado, julg. 31.01.2007, v.u.

SÃO PAULO (estado). Tribunal de Justiça de São Paulo. Agravo de Instrumento $\mathrm{n}^{\circ}$ 465.399-4/6-00, Rel. Des. A. C. Mathias Coltro, 5 $5^{\text {a }}$ Câmara de Direito Privado, julg. 31.01.2007, v.u. Disponível em: 〈http://www.tj.sp.gov.br〉. Acesso em: 17 ago. 2010.

SÃO PAULO (estado). Tribunal de Justiça de São Paulo. Agravo de Instrumento ${ }^{\circ}$ 472.715-4/6-00, Rel. Des. Francisco Loureiro, 4 ${ }^{\mathrm{a}}$ Câmara de Direito Privado, julg. 07.12.2006, v.u. Disponível em: <http://www.tj.sp.gov.br>. Acesso em: 17 ago. 2010. 
SÃO PAULO (estado). Tribunal de Justiça de São Paulo. Apelação no 1339150-7, Rel. Des. Ana Cristina Ramos, 23 ${ }^{\mathrm{a}}$ Câmara de Direito Privado, julg. 01.09.2006,v.m. Disponível em: <http://www.tj.sp.gov.br>. Acesso em: 17 ago. 2010.

SÃO PAULO (estado). Tribunal de Justiça de São Paulo. Agravo de Instrumento ${ }^{\circ}$ 1.329.185-7, Rel. Des. Coti Machado, $7^{\text {a }}$ Câmara de Direito Privado, julg. 01.03.2005, v.u. Disponível em: <http://www.tj.sp.gov.br>. Acesso em: 17 ago. 2010.

SÃO PAULO (estado). Tribunal de Justiça de São Paulo. Agravo de Instrumento ${ }^{\circ}$ 7045860-5, Rel. Des. Gil Ernesto Gomes Coelho, $11^{\text {a }}$ Câmara de Direito Privado, julg. 29.06.2006, v.u. Disponível em: 〈http://www.tj.sp.gov.br〉. Acesso em: 17 ago. 2010.

SÃO PAULO (estado). Tribunal de Justiça de São Paulo. Agravo de Instrumento ${ }^{\circ}$ 7045861-2, Rel. Des. Gil Ernesto Gomes Coelho, $11^{\text {a }}$ Câmara de Direito Privado, julg. 25.05.2006, v.u. Disponível em: 〈http://www.tj.sp.gov.br〉. Acesso em: 17 ago. 2010.

SÃO PAULO (estado). Tribunal de Justiça de São Paulo. Embargos Declaratórios ${ }^{\circ}$ 887143-1/5, Rel. Des. Andrade Neto, 30ª Câmara de Direito Privado, julg. 03. 05.2006, v.u. Disponível em: 〈http://www.tj.sp.gov.br>. Acesso em: 17 ago. 2010.

SÃO PAULO (estado). Tribunal de Justiça de São Paulo. Agravo de Instrumento ${ }^{\circ}$ 437.553-4/0-00, Rel. Des. Francisco Loureiro, 4 ${ }^{\mathrm{a}}$ Câmara de Direito Privado, julg. 09.03.2006, v.u. Disponível em: 〈http://www.tj.sp.gov.br〉. Acesso em: 17 ago. 2010.

SÃO PAULO (estado). Tribunal de Justiça de São Paulo. Apelação no 7029215-0, Rel. Des. Rodrigo Augusto de Oliveira, 23 a Câmara de Direito Privado, julg. 10.03.2006,v.u. Disponível em: <http://www.tj.sp.gov.br>. Acesso em: 17 ago. 2010.

SÃO PAULO (estado). Tribunal de Justiça de São Paulo. Agravo de Instrumento ${ }^{\circ}$ 365.184-4/6-00, Rel. Des. Ribeiro da Silva, $8^{\text {a }}$ Câmara de Direito Privado, julg. 24.11.2005, v.u. Disponível em: 〈http://www.tj.sp.gov.br〉. Acesso em: 17 ago. 2010.

SÃO PAULO (estado). Tribunal de Justiça de São Paulo. Agravo de Instrumento ${ }^{\circ}$ 887143-0/3, Rel. Des. Andrade Neto, 30ª Câmara de Direito Privado, julg.26.10.2005, v.m. Disponível em: <http://www.tj.sp.gov.br>. Acesso em: 17 ago. 2010.

SÃO PAULO (estado). Tribunal de Justiça de São Paulo. Agravo de Instrumento ${ }^{\circ}$ 
392.186-4/8-00, Rel. Des. Reis Kuntz, 6 a Câmara de Direito privado, julg. 20.10.2005, v.u. Disponível em: <http://www.tj.sp.gov.br>. Acesso em: 17 ago. 2010.

SÃO PAULO (estado). Tribunal de Justiça de São Paulo. Mandado de Segurança n ${ }^{\circ}$ 381.780-4/3-00, Rel. Des. João Carlos Garcia, 9a Câmara de Direito Privado, julg. 04.10.2005, v.u. Disponível em: 〈http://www.tj.sp.gov.br〉. Acesso em: 17 ago. 2010.

SÃO PAULO (estado). Tribunal de Justiça de São Paulo, Agravo de Instrumento ${ }^{\circ}$ 374.769-4/7, Rel. Des. Antonio Vilenilson, 9a Câmara de Direito Privado, julg. 27.09.2005, v.u. Disponível em: 〈http://www.tj.sp.gov.br〉. Acesso em: 17 ago. 2010.

SÃO PAULO (estado). Tribunal de Justiça de São Paulo. Agravo de Instrumento ${ }^{\circ}$ 959530-0/9, Rel. Des. Campos Petroni, 27 Câmara de Direito Privado, julg. 20.09.2005, v.u. Disponível em: <http://www.tj.sp.gov.br>. Acesso em: 17 ago. 2010.

\section{Acórdãos em que a desconsideração da personalidade jurídica nos grupos societários foi indeferida}

BRASIL. Supremo Tribunal de Justiça. Recurso Especial no 744.107/SP, Rel. Min. Fernando Gonçalves, Quarta Turma, julg. 20.05.2008, v.u. Disponível em: <http://www.stj.jus.br>. Acesso em: 6 set 2010.

BRASIL. Supremo Tribunal de Justiça. Recurso Especial nº 968.564/RS, Rel. Min. Arnaldo Esteves Lima, Quinta Turma, julg. 18.12. 2008, v.u. Disponível em: <http://www.stj.jus.br>. Acesso em: 6 set 2010.

SÃO PAULO (estado). Tribunal de Justiça de São Paulo. Agravo de Instrumento ${ }^{\circ}$ 990.10.027869-0, Rel. Des. Pedro Ablas, 14ª Câmara de Direito Privado, julg. 23.06.2010, v.u. Disponível em: 〈http://www.tj.sp.gov.br>. Acesso em: 17 ago. 2010.

SÃO PAULO (estado). Tribunal de Justiça de São Paulo. Agravo de Instrumento ${ }^{\circ}$ 990.10.169819-6, Rel. Des. J. B. Franco de Godoi, 23 a Câmara de Direito Privado, julg. 28.07.2010, v.u. Disponível em: 〈http://www.tj.sp.gov.br〉. Acesso em: 17 ago. 2010.

SÃO PAULO (estado). Tribunal de Justiça de São Paulo. Apelação no 992.05.137765-8, 
Rel. Des. Francisco Casconi, 31 ${ }^{\mathrm{a}}$ Câmara de Direito Privado, julg. 06.07.2010, v.u. Disponível em: <http://www.tj.sp.gov.br>. Acesso em: 17 ago. 2010.

SÃO PAULO (estado). Tribunal de Justiça de São Paulo. Agravo de Instrumento ${ }^{\circ}$ 991.09.054380-8, Rel. Des. Alexandre Lazzarini, $18^{\text {a }}$ Câmara De Direito Privado, julg. 25.05.2010, v.u. Disponível em: 〈http://www.tj.sp.gov.br〉. Acesso em: 17 ago. 2010.

SÃO PAULO (estado). Tribunal de Justiça de São Paulo. Agravo de Instrumento ${ }^{\circ}$ 990.09.319830-4, Rel. Des. Walter Zeni, 32 a Câmara de Direito Privado, julg. 01.07.2010, v.u. Disponível em: 〈http://www.tj.sp.gov.br〉. Acesso em: 17 ago. 2010.

SÃO PAULO (estado). Tribunal de Justiça de São Paulo. Agravo de Instrumento ${ }^{\circ}$ 990.10.086900-0, Rel. Des. Ademir Benedito, 21 a Câmara de Direito Privado, julg. 09.06.2010, v.u. Disponível em: 〈http://www.tj.sp.gov.br〉. Acesso em: 17 ago. 2010.

SÃO PAULO (estado). Tribunal de Justiça de São Paulo. Agravo de Instrumento ${ }^{\circ}$ 990.10.067054-9, Rel. Des. Elmano de Oliveira, 23 ${ }^{\text {a }}$ Câmara de Direito Privado, julg. 09.06.2010, v.u. Disponível em: <http://www.tj.sp.gov.br>. Acesso em: 17 ago. 2010.

SÃO PAULO (estado). Tribunal de Justiça de São Paulo. Agravo de Instrumento $\mathrm{n}^{\circ}$ 990.09.313847-6, Rel. Des. Eduardo Sá Pinto Sandeville, 28ª Câmara de Direito Privado, julg.16.03.2010, v.u. Disponível em: <http://www.tj.sp.gov.br>. Acesso em: 17 ago. 2010.

SÃO PAULO (estado). Tribunal de Justiça de São Paulo. Agravo de Instrumento ${ }^{\circ}$ 994.09.280419-8, Rel. Des. Beretta da Silveira, $3^{\text {a }}$ Câmara de Direito Privado, julg. 09.03.2010, v.u. Disponível em: <http://www.tj.sp.gov.br>. Acesso em: 17 ago. 2010.

SÃO PAULO (estado). Tribunal de Justiça de São Paulo. Agravo de Instrumento ${ }^{\circ}$ 991.08.050222-9, Rel. Des. William Marinho, $18^{\text {a }}$ Câmara de Direito Privado, julg. 24.11.2009, v.u. Disponível em: 〈http://www.tj.sp.gov.br〉. Acesso em: 17 ago. 2010.

SÃO PAULO (estado). Tribunal de Justiça de São Paulo. Agravo de Instrumento ${ }^{\circ}$ 991.08.078768-8, Rel. Des. William Marinho, 18 $18^{\mathrm{a}}$ Câmara de Direito Privado, julg. 24.11.2009, v.u. Disponível em: 〈http://www.tj.sp.gov.br〉. Acesso em: 17 ago. 2010.

SÃO PAULO (estado). Tribunal de Justiça de São Paulo. Agravo de Instrumento ${ }^{\circ}$ 991.08.085391-0, Rel. Des. Paulo Roberto de Santana, 23ª Câmara de Direito Privado, 
julg. 16.12.2009, v.u. Disponível em: <http://www.tj.sp.gov.br>. Acesso em: 17 ago. 2010.

SÃO PAULO (estado). Tribunal de Justiça de São Paulo. Agravo de Instrumento ${ }^{\circ}$ 990.09.230578-6, Rel. Des. Carlos Nunes, 33 ${ }^{\text {a }}$ Câmara de Direito Privado, julg. 01.02.2010, v.u. Disponível em: 〈http://www.tj.sp.gov.br〉. Acesso em: 17 ago. 2010.

SÃO PAULO (estado). Tribunal de Justiça de São Paulo. Agravo de Instrumento ${ }^{\circ}$ 990.09.276489-6, Rel. Des. Emanuel Oliveira, 27 Câmara de Direito Privado, julg. 19.01.2010, v.u. Disponível em: 〈http://www.tj.sp.gov.br〉. Acesso em: 17 ago. 2010.

SÃO PAULO (estado). Tribunal de Justiça de São Paulo. Agravo de Instrumento $\mathrm{n}^{\circ}$ 991.09.035179-8, Rel. Des. Roberto Bedaque, 22 $2^{\mathrm{a}}$ Câmara de Direito Privado, julg. 16.12.2009, v.u. Disponível em: 〈http://www.tj.sp.gov.br>. Acesso em: 17 ago. 2010.

SÃO PAULO (estado). Tribunal de Justiça de São Paulo. Apelação nº 992.08.032388-9, Rel. Des. Antonio Benedito Ribeiro Pinto, 25 Câmara de Direito Privado, julg. 10.12.2009, v.u. Disponível em: 〈http://www.tj.sp.gov.br〉. Acesso em: 17 ago. 2010.

SÃO PAULO (estado). Tribunal de Justiça de São Paulo. Apelação com Revisão ${ }^{\circ}$ 1.235.743-4, Rel. Des. Cláudio Augusto Pedrassi, 20ª Câmara de Direito Privado, julg. 01.12.2009, v.u. Disponível em: 〈http://www.tj.sp.gov.br〉. Acesso em: 17 ago. 2010.

SÃO PAULO (estado). Tribunal de Justiça de São Paulo. Agravo de Instrumento ${ }^{\circ}$ 7384820-5, Rel. Des. Elmano de Oliveira, 23ª Câmara de Direito Privado, julg. 29.10.2009, v.u. Disponível em: <http://www.tj.sp.gov.br>. Acesso em: 17 ago. 2010.

SÃO PAULO (estado). Tribunal de Justiça de São Paulo. Agravo de Instrumento $\mathrm{n}^{\mathrm{o}}$ 992.08.061282-1, Rel. Des. Francisco Thomaz, 29ª Câmara de Direito Privado, julg. 21.10.2009, v.u. Disponível em: <http://www.tj.sp.gov.br>. Acesso em: 17 ago. 2010.

SÃO PAULO (estado). Tribunal de Justiça de São Paulo. Agravo de Instrumento ${ }^{\circ}$ 992.09.067007-7, Rel. Des. José Malerbi, 35 Câmara de Direito Privado, julg. 19.10.2009, v.u. Disponível em: 〈http://www.tj.sp.gov.br>. Acesso em: 17 ago. 2010.

SÃO PAULO (estado). Tribunal de Justiça de São Paulo. Agravo de Instrumento ${ }^{\circ}$ 992.08.067709-5, Rel. Des. Luiz Felipe Nogueira, 30ª Câmara de Direito Privado, julg. 16.09.2009, v.u. Disponível em: 〈http://www.tj.sp.gov.br〉. Acesso em: 17 ago. 2010. 
SÃO PAULO (estado). Tribunal de Justiça de São Paulo. Agravo de Instrumento ${ }^{\circ}$ 650.416-4/9-00, Rel. Des. Ribeiro da Silva, $8^{a}$ Câmara de Direito Privado, julg. 16.09.2009, v.u. Disponível em: 〈http://www.tj.sp.gov.br>. Acesso em: 17 ago. 2010.

SÃO PAULO (estado). Tribunal de Justiça de São Paulo. Agravo de Instrumento ${ }^{\circ}$ 7.371.685-1, Rel. Des. Silveira Paulilo, 21 a Câmara de Direito Privado, julg. 19.08.2009, v.u. Disponível em: <http://www.tj.sp.gov.br>. Acesso em: 17 ago. 2010.

SÃO PAULO (estado). Tribunal de Justiça de São Paulo. Agravo de Instrumento ${ }^{\circ}$ 642.495-4/4-00, Rel. Des. Romeu Ricupero, Câmara Especial de Falências e Recuperações Judiciais de Direito Privado, julg. 18.08.2009, v.u. Disponível em: <http://www.tj.sp.gov.br>. Acesso em: 17 ago. 2010.

SÃO PAULO (estado). Tribunal de Justiça de São Paulo. Apelação com Revisão n ${ }^{\circ}$ 973565-0/7, Rel. Des. Francisco Casconi, 31 a Câmara de Direito Privado, julg. 04.08.2009, v.u. Disponível em: 〈http://www.tj.sp.gov.br〉. Acesso em: 17 ago. 2010.

SÃO PAULO (estado). Tribunal de Justiça de São Paulo. Agravo de Instrumento ${ }^{\circ}$ 1266133-0/8, Rel. Des. Cesar Lacerda, 28 a Câmara de Direito Privado, julg. 28.07.2009, v.u. Disponível em: 〈http://www.tj.sp.gov.br>. Acesso em: 17 ago. 2010.

SÃO PAULO (estado). Tribunal de Justiça de São Paulo. Agravo de Instrumento ${ }^{\circ}$ 1251492-0/9, Rel. Des. José Malerbi, 35ª Câmara de Direito Privado, julg. 29.06.2009, v.u. Disponível em: 〈http://www.tj.sp.gov.br>. Acesso em: 17 ago. 2010.

SÃO PAULO (estado). Tribunal de Justiça de São Paulo. Agravo de Instrumento ${ }^{\circ}$ 631.327-4/3-00, Rel. Des. Luiz Antonio de Godoy, $1^{\text {a }}$ Câmara de Direito Privado, julg. 02.07.2009, v.u. Disponível em: 〈http://www.tj.sp.gov.br〉. Acesso em: 17 ago. 2010.

SÃO PAULO (estado). Tribunal de Justiça de São Paulo. Agravo de Instrumento ${ }^{\circ}$ 1235227-0/5, Rel. Des. Arantes Theodoro, 36 ${ }^{\mathrm{a}}$ Câmara de Direito Privado, julg. 26.03.2009, v.u. Disponível em: 〈http://www.tj.sp.gov.br〉. Acesso em: 17 ago. 2010.

SÃO PAULO (estado). Tribunal de Justiça de São Paulo. Agravo de Instrumento ${ }^{\circ}$ 597.556-4/1-00, Rel. Des. Morato de Andrade, 2 a Câmara de Direito Privado, julg. 03.03.2009, v.u. Disponível em: 〈http://www.tj.sp.gov.br〉. Acesso em: 17 ago. 2010. 
SÃO PAULO (estado). Tribunal de Justiça de São Paulo. Agravo de Instrumento ${ }^{\circ}$ 601.640-4/7-00, Rel. Des. Morato de Andrade, 2 ${ }^{\text {a }}$ Câmara de Direito Privado, julg. 03.03.2009, v.u. Disponível em: 〈http://www.tj.sp.gov.br〉. Acesso em: 17 ago. 2010.

SÃO PAULO (estado). Tribunal de Justiça de São Paulo. Apelação Cível no 574.557.4/800, Rel. Des. Francisco Loureiro, 4a Câmara de Direito Privado, julg. 18.12.2008, v.u. Disponível em: <http://www.tj.sp.gov.br>. Acesso em: 17 ago. 2010.

SÃO PAULO (estado). Tribunal de Justiça de São Paulo. Agravo de Instrumento ${ }^{\circ}$ 7298321-4, Rel. Des. Ricardo Negrão, 19ª Câmara de Direito Privado, julg, 15.12.2008, v.u. Disponível em: 〈http://www.tj.sp.gov.br〉. Acesso em: 17 ago. 2010.

SÃO PAULO (estado). Tribunal de Justiça de São Paulo. Agravo de Instrumento ${ }^{\circ}$ 819625/87, Rel. Des. Julio Vidal, 28 a Câmara de Direito Privado, julg. 13.01.2009, v.u. Disponível em: <http://www.tj.sp.gov.br>. Acesso em: 17 ago. 2010.

SÃO PAULO (estado). Tribunal de Justiça de São Paulo., Agravo de Instrumento $\mathrm{n}^{\circ}$ 7293295-9, Rel. Des. Térsio Negrato, $17^{\mathrm{a}}$ Câmara de Direito Privado, julg. 15.12.2008, v.u. Disponível em: 〈http://www.tj.sp.gov.br>. Acesso em: 17 ago. 2010.

SÃO PAULO (estado). Tribunal de Justiça de São Paulo. Apelação Cível com Revisão n ${ }^{\circ}$ 575.202-4/6-00, Rel. Des. Elliot Akel, Câmara Especial de Falências e Recuperações Judiciais de Direito Privado, julg. 19.11.2008, v.u. Disponível em: <http://www.tj.sp.gov.br>. Acesso em: 17 ago. 2010.

SÃO PAULO (estado). Tribunal de Justiça de São Paulo. Agravo de Instrumento ${ }^{\circ}$ 7298539-6, Rel. Des. Térsio Negrato, 17ª Câmara de Direito Privado, julg. 30.10.2008, v.u. Disponível em: <http://www.tj.sp.gov.br>. Acesso em: 17 ago. 2010.

SÃO PAULO (estado). Tribunal de Justiça de São Paulo. Agravo de Instrumento ${ }^{\circ}$ 7.268.820-3, Rel. Des. José Marcos Marrone, 23 ${ }^{\mathrm{a}}$ Câmara de Direito Privado, julg.10.09.2008, v.u. Disponível em: 〈http://www.tj.sp.gov.br〉. Acesso em: 17 ago. 2010.

SÃO PAUlO (estado). Tribunal de Justiça de São Paulo. Apelação no 1319328-9, Rel. Des. Térsio Negrato, $17^{\mathrm{a}}$ Câmara de Direito Privado, julg. 04.06.2008, v.u. Disponível em: <http://www.tj.sp.gov.br>. Acesso em: 17 ago. 2010. 
SÃO PAULO (estado). Tribunal de Justiça de São Paulo. Agravo de Instrumento ${ }^{\circ}$ 541.712.4/0-00, Rel. Des. Francisco Loureiro, $4^{\mathrm{a}}$ Câmara de Direito Privado, julg. 19.06.2008, v.u. Disponível em: 〈http://www.tj.sp.gov.br〉. Acesso em: 17 ago. 2010.

SÃO PAULO (estado). Tribunal de Justiça de São Paulo. Agravo de Instrumento ${ }^{\circ}$ 7228586-4, Rel. Des. Térsio Negrato, 17 a Câmara de Direito Privado, julg. 07.05.2008, v.u. Disponível em: <http://www.tj.sp.gov.br>. Acesso em: 17 ago. 2010.

SÃO PAULO (estado). Tribunal de Justiça de São Paulo. Agravo de Instrumento ${ }^{\circ}$ 7207355-9, Rel. Des. Ricardo Negrão, 19ª Câmara de Direito Privado, Julg. 15.04.2008, v.u. Disponível em: 〈http://www.tj.sp.gov.br〉. Acesso em: 17 ago. 2010.

SÃO PAULO (estado). Tribunal de Justiça de São Paulo. Agravo de Instrumento ${ }^{\circ}$ 7188797-3, Rel. Des. Campos Mello, 22 ${ }^{\mathrm{a}}$ Câmara de Direito Privado, julg. 29.01.2008, v.u. Disponível em: <http://www.tj.sp.gov.br>. Acesso em: 17 ago. 2010.

SÃO PAULO (estado). Tribunal de Justiça de São Paulo. Agravo de Instrumento ${ }^{\circ}$ 716.230-5-3, Rel. Des. Ricardo Dip, $11^{a}$ Câmara de Direito Privado, Julg. 10.12.2007, v.u. Disponível em: <http://www.tj.sp.gov.br>. Acesso em: 17 ago. 2010.

SÃO PAULO (estado). Tribunal de Justiça de São Paulo. Agravo de Instrumento ${ }^{\circ}$ 1136321-0/7, Rel. Des. Andrade Neto, 30ª Câmara de Direito Privado, julg. 19.12.2007, v.u. Disponível em: <http://www.tj.sp.gov.br>. Acesso em: 17 ago. 2010.

SÃO PAULO (estado). Tribunal de Justiça de São Paulo. Agravo de Instrumento ${ }^{\circ}$ 7156540-7, Rel. Des. Walter Fonseca, 24 a Câmara de Direito Privado, julg. 23.08.2007, v.u. Disponível em: <http://www.tj.sp.gov.br>. Acesso em: 17 ago. 2010.

SÃO PAULO (estado). Tribunal de Justiça de São Paulo. Apelação no 7.066.234-5, Rel. Des. Antonio Ribeiro, $15^{\text {a }}$ Câmara de Direito Privado, julg. 27.11.2007, v.u. Disponível em: <http://www.tj.sp.gov.br>. Acesso em: 17 ago. 2010.

SÃO PAULO (estado). Tribunal de Justiça de São Paulo. Agravo de Instrumento ${ }^{\circ}$ 7179335-4, Rel. Des. Gilberto dos Santos, 11 a Câmara de Direito Privado, julg. 08.11.2007, v.u. Disponível em: 〈http://www.tj.sp.gov.br〉. Acesso em: 17 ago. 2010.

SÃO PAULO (estado). Tribunal de Justiça de São Paulo. Agravo de Instrumento ${ }^{\circ}$ 
7.171.017-9, Rel. Des. Melo Colombi, 14ª Câmara de Direito Privado, julg. 05.09.2007, v.u. Disponível em: 〈http://www.tj.sp.gov.br〉. Acesso em: 17 ago. 2010.

SÃO PAULO (estado). Tribunal de Justiça de São Paulo. Agravo de Instrumento ${ }^{\circ}$ 7152700-7, Rel. Des. Rubens Cury, $18^{\text {a }}$ Câmara de Direito Privado, julg. 14. 08.2007, v.u. Disponível em: <http://www.tj.sp.gov.br>. Acesso em: 17 ago. 2010.

SÃO PAULO (estado). Tribunal de Justiça de São Paulo. Agravo de Instrumento ${ }^{\circ}$ 7150500-9, Rel. Des. Ricardo Negrão, 19ª Câmara de Direito Privado, julg. 24.07.2007, v.u. Disponível em: 〈http://www.tj.sp.gov.br〉. Acesso em: 17 ago. 2010.

SÃO PAULO (estado). Tribunal de Justiça de São Paulo. Agravo de Instrumento ${ }^{\circ}$ 1091449-0/4, Rel. Des. Amorim Cantuaria, 25 a Câmara de Direito Privado, julg. 24.07.2007, v.u. Disponível em: 〈http://www.tj.sp.gov.br〉. Acesso em: 17 ago. 2010.

SÃO PAULO (estado). Tribunal de Justiça de São Paulo. Agravo de Instrumento ${ }^{\circ}$ 7128232-9, Rel. Des. Celso Alves de Rezende, $11^{\text {a }}$ Câmara de Direito Privado, julg. 29.06.2007, v.u. Disponível em: <http://www.tj.sp.gov.br>. Acesso em: 17 ago. 2010.

SÃO PAULO (estado). Tribunal de Justiça de São Paulo. Agravo de Instrumento $\mathrm{n}^{\circ}$ 1105317-0/6, Rel. Des. Egidio Giacoia, 35ª Câmara de Direito Privado, julg. 18.06.07, v.u. Disponível em: <http://www.tj.sp.gov.br>. Acesso em: 17 ago. 2010.

SÃO PAULO (estado). Tribunal de Justiça de São Paulo. Apelação com Revisão n ${ }^{\circ}$ 972471-0/5, Rel. Des. Felipe Ferreira, 26ª Câmara de Direito Privado, julg. 04.06.2007, v.u. Disponível em: 〈http://www.tj.sp.gov.br>. Acesso em: 17 ago. 2010.

SÃO PAULO (estado). Tribunal de Justiça de São Paulo. Apelação no 1.107.997-9, Rel. Des. Newton Neves, $16^{\mathrm{a}}$ Câmara de Direito Privado, julg. 24.04.2007, v.u. Disponível em: <http://www.tj.sp.gov.br>. Acesso em: 17 ago. 2010.

SÃO PAULO (estado). Tribunal de Justiça de São Paulo. Agravo de Instrumento ${ }^{\circ}$ 7140710-2, Rel. Des. Campos Mello, 22a Câmara de Direito Privado, julg. 15.05.2007, v.u. Disponível em: <http://www.tj.sp.gov.br>. Acesso em: 17 ago. 2010.

SÃO PAULO (estado). Tribunal de Justiça de São Paulo. Apelação com Revisão n ${ }^{\circ}$ 1060838-0/0, Rel. Des. Kioitsi Chicuta, 32a Câmara de Direito Privado, julg. 10.05.2007, 
v.u. Disponível em: <http://www.tj.sp.gov.br>. Acesso em: 17 ago. 2010.

SÃO PAULO (estado). Tribunal de Justiça de São Paulo. Agravo de Instrumento ${ }^{\circ}$ 7131934-3, Rel. Des. Campos Mello, 22a Câmara de Direito Privado, julg. 24.04.2007, v.u. Disponível em: <http://www.tj.sp.gov.br>. Acesso em: 17 ago. 2010.

SÃO PAULO (estado). Tribunal de Justiça de São Paulo. Agravo de Instrumento ${ }^{\circ}$ 1097565-0/2, Rel. Des. Orlando Pistoresi, 30 a Câmara de Direito Privado, julg. 28.03.2007, v.u. Disponível em: 〈http://www.tj.sp.gov.br>. Acesso em: 17 ago. 2010.

SÃO PAULO (estado). Tribunal de Justiça de São Paulo. Apelação Cível n 7.068.820-9, Rel. Des. Waldir de Souza José, 15ª Câmara de Direito Privado, julg. 13.03.2007, v.u. Disponível em: <http://www.tj.sp.gov.br>. Acesso em: 17 ago. 2010.

SÃO PAULO (estado). Tribunal de Justiça de São Paulo. Apelação com Revisão no 830013-0/3, Rel. Des. Francisco Carlos Inouye Shintate, 36a Câmara de Direito Privado, julg. 01.03.2007, v.u. Disponível em: 〈http://www.tj.sp.gov.br〉. Acesso em: 17 ago. 2010.

SÃO PAULO (estado). Tribunal de Justiça de São Paulo. Agravo de Instrumento ${ }^{\circ}$ 451.527.4/4-00, Rel. Des. Francisco Loureiro, $4^{\mathrm{a}}$ Câmara de Direito Privado, julg. 19.10.2006, v.u. Disponível em: 〈http://www.tj.sp.gov.br>. Acesso em: 17 ago. 2010.

SÃO PAULO (estado). Tribunal de Justiça de São Paulo. Apelação no 7.028.401-2, Rel. Des. Carlos Von Adamek, 14 ${ }^{\mathrm{a}}$ Câmara de Direito Privado, julg. 06.10.2006, v.u. Disponível em: 〈http://www.tj.sp.gov.br〉. Acesso em: 17 ago. 2010.

SÃO PAULO (estado). Tribunal de Justiça de São Paulo. Apelação n ${ }^{\circ}$ 1.271.821-9, Rel. Des. Waldir de Souza José, 15 ${ }^{\mathrm{a}}$ Câmara de Direito Privado, julg. 22.08.2006, v.u. Disponível em: <http://www.tj.sp.gov.br>. Acesso em: 17 ago. 2010.

SÃO PAULO (estado). Tribunal de Justiça de São Paulo. Apelação nº 7071355-2, Rel. Des. Gilberto Pinto dos Santos, 11 a Câmara de Direito Privado, julg. 14.09.2006, v.u. Disponível em: <http://www.tj.sp.gov.br>. Acesso em: 17 ago. 2010.

SÃO PAULO (estado). Tribunal de Justiça de São Paulo. Agravo de Instrumento ${ }^{\circ}$ 7.047.815-8, Rel. Des. Candido Alem, 16 Câmara de Direito Privado, julg. 28.06.2006, v.u. Disponível em: 〈http://www.tj.sp.gov.br>. Acesso em: 17 ago. 2010. 
SÃO PAULO (estado). Tribunal de Justiça de São Paulo. Agravo de Instrumento ${ }^{\circ}$ 429.724-4/7-00, Rel. Des. J. G. Jacobina Rabello, 4 ${ }^{\mathrm{a}}$ Câmara de Direito Privado, julg. 18.05.2006, v.u. Disponível em: 〈http://www.tj.sp.gov.br〉. Acesso em: 17 ago. 2010.

SÃO PAULO (estado). Tribunal de Justiça de São Paulo. Embargos de Declaração n ${ }^{\circ}$ 7.039.852-6/01, Rel. Des. Luis Carlos de Barros, 20ª Câmara de Direito Privado, julg. 14.03.2006, v.u. Disponível em: 〈http://www.tj.sp.gov.br>. Acesso em: 17 ago. 2010.

SÃO PAULO (estado). Tribunal de Justiça de São Paulo. Agravo de Instrumento ${ }^{\circ}$

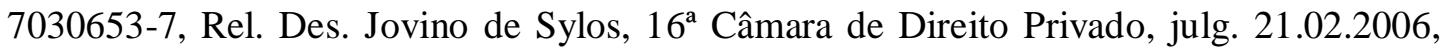
v.u. Disponível em: 〈http://www.tj.sp.gov.br〉. Acesso em: 17 ago. 2010.

SÃO PAULO (estado). Tribunal de Justiça de São Paulo. Agravo de Instrumento ${ }^{\circ}$ 1011118-0/2, Rel. Des. Ricardo Pessoa de Mello Belli, 25ª Câmara de Direito Privado, julg. 21.02.2006, v.u. Disponível em: 〈http://www.tj.sp.gov.br〉. Acesso em: 17 ago. 2010.

SÃO PAULO (estado). Tribunal de Justiça de São Paulo. Agravo de Instrumento ${ }^{\circ}$ 907367-1/0, Rel. Des. Julio Vidal, $28^{\text {a }}$ Câmara de Direito Privado, julg. 14.02.2006, v.u. Disponível em: <http://www.tj.sp.gov.br>. Acesso em: 17 ago. 2010.

SÃO PAULO (estado). Tribunal de Justiça de São Paulo. Apelação no 1.001.320-2, Rel. Des. Roque Mesquita, $18^{\mathrm{a}}$ Câmara de Direito Privado, julg. 15.12.2005, v.u. Disponível em: 〈http://www.tj.sp.gov.br>. Acesso em: 17 ago. 2010.

SÃO PAULO (estado). Tribunal de Justiça de São Paulo. Mandado de Segurança ${ }^{\circ}$ 7.039.533-6, Rel. Des. Paulo Hatanaka, 19ª Câmara de Direito Privado, julg.13.12.2005, v.u. Disponível em: 〈http://www.tj.sp.gov.br>. Acesso em: 17 ago. 2010.

SÃO PAULO (estado). Tribunal de Justiça de São Paulo. Agravo de Instrumento ${ }^{\circ}$ 374.672-4/4-00, Rel. Des. Ribeiro da Silva, $8^{\text {a }}$ Câmara de Direito Privado, julg. 15.09.2005, v.u. Disponível em: 〈http://www.tj.sp.gov.br〉. Acesso em: 17 ago. 2010.

SÃO PAULO (estado). Tribunal de Justiça de São Paulo. Agravo de Instrumento ${ }^{\circ}$ 7.018.550-7, Rel. Des. Antonio Marson, 21 a Câmara de Direito Privado, julg. 31.08.2005, v.u. Disponível em: 〈http://www.tj.sp.gov.br〉. Acesso em: 17 ago. 2010.

SÃO PAULO (estado). Tribunal de Justiça de São Paulo. Apelação com Revisão n ${ }^{o}$ 
754023-0/0, Rel. Des. Arantes Theodoro, 36 a Câmara de Direito Privado, julg. 15.09.2005, v.u. Disponível em: <http://www.tj.sp.gov.br〉. Acesso em: 17 ago. 2010.

SÃO PAULO (estado). Tribunal de Justiça de São Paulo. Agravo de Instrumento $\mathrm{n}^{\circ}$ 360.710-4/1-00, Rel. Des. Ribeiro da Silva, $8^{a}$ Câmara de Direito Privado, julg. 25.08.2005, v.u. Disponível em: 〈http://www.tj.sp.gov.br〉. Acesso em: 17 ago. 2010.

SÃO PAULO (estado). Tribunal de Justiça de São Paulo. Agravo de Instrumento ${ }^{\circ}$ 369.625-4/9-00, Rel. Des. Ribeiro da Silva, $8^{a}$ Câmara de Direito Privado, julg. 25.08.2005, v.u. Disponível em: <http://www.tj.sp.gov.br>. Acesso em: 17 ago. 2010.

SÃO PAULO (estado). Tribunal de Justiça de São Paulo. Apelação no 1.098.720-7, Rel. Des. Salles Vieira, $18^{\mathrm{a}}$ Câmara de Direito Privado, julg. 08.09.2005, v.u. Disponível em: <http://www.tj.sp.gov.br>. Acesso em: 17 ago. 2010. 